$$
D R-1318-8
$$

(16)

UCID-19975-2

UCID--19975-2

DEB5 018551

\title{
Fusion Power Demonstration III
}

\author{
Technical Editor: J. D. Lee
}

July 1985

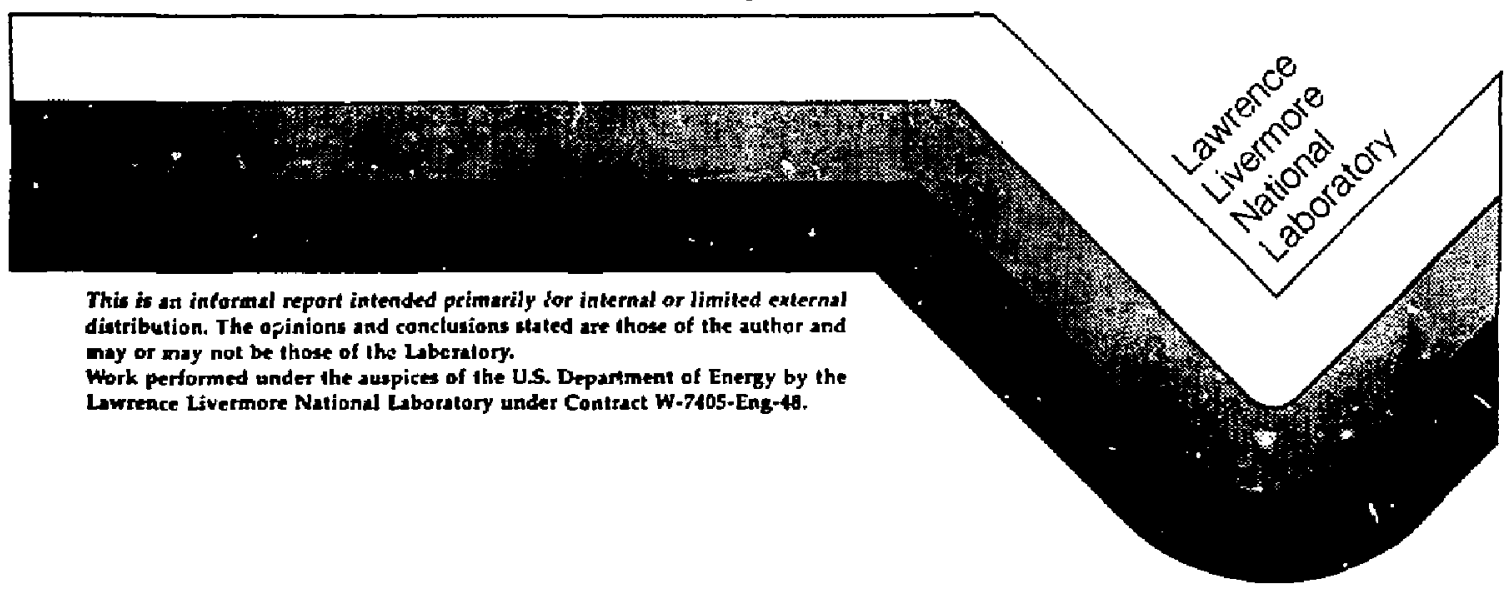

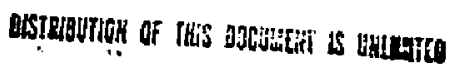




\section{Participants}

\section{Lawrence Livermore National Laberatory}

W. L. Barr, A. H. Bulmer, S. A. Devolo, J. N. Doggett, J. D. Lee, B. G. Logan, L. J. Perkins, and W. S. Neef

\section{Oak Ridgo National Laboratory, Fusion Engineering Dosign Center}

G. T. Bussel, S. A. Freije, G. E. Gorker, J. R. Haines, W. R. Hamilton, S. S. Kalsi, D. C. Lousteau, W. D. Nelson

P. T. Spampinato, Y. C. Srivistava, and G. E. Taylor

Grumman Aerospace Corporation

I. F. Clarkson and T. E. Luzzi

TAW

ค. B. Campbell and M. E. Fenstermacher

General Dynamics/Convair Division

K. L. Agarwal, R. W. Baldi, J. E. Burgeson, J. Parmer, S. D. Peck, and J. C. Yu

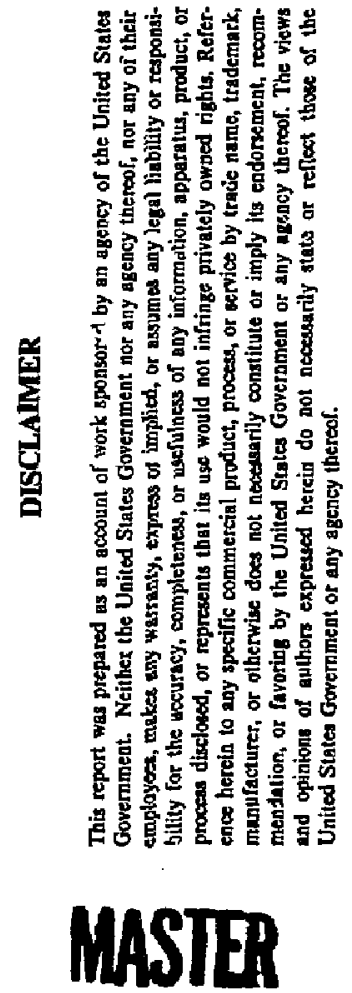




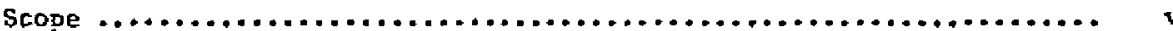

1.0 Introduction (J. N. Doggett) $\ldots \ldots \ldots \ldots \ldots \ldots \ldots \ldots \ldots \ldots \ldots \ldots \ldots, 1-1$

Reference $\ldots \ldots \ldots \ldots \ldots \ldots \ldots \ldots \ldots \ldots \ldots \ldots \ldots \ldots \ldots \ldots \ldots \ldots \ldots \ldots, 1-3$

2.0 Plabne Engineering (L. J. Perkins) ........................ 2-1 Introduction--The Rationale for Using Octopole Plugs ........... 2-1

The Physics Basis of FPD-III ............................ 2-3

The Octopole Magnetic Configuration, MHD Stability,

and the llot Electron Mantle .......................... 2-7

The Iqnition Criterion ................................. 2-16

Halo and Direct Converter Physics ........................ 2-18

Alpha-Particle Energy Loss to the Halo Plasma ................ 2-2l

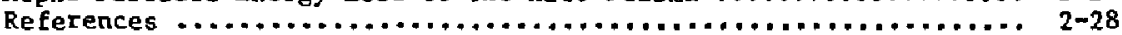

3.0 Sygtems Design .................................... 3-1

General Description (D. C. Lousteau, W. D. Nelson) ............ 3-1

Central Cell Magnets (v. c. Srivistava) ....................... 3-11

System Function summary ........................... 3-14

Requirement Surmary ............................. j-14

Magnet Configuration and Design ...................... 3-14

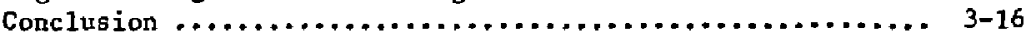

Central Cell Shielding (G. E. Taylor) ..................... 3-16

Fuel Injection Systems (G. E. Gorker) ..................... 3-17

Fuel Gas Injection ................................ 3-17

Fuel Pellet Injection ............................. 3-17

Magnets (s. s. Kalsi) ................................... 3-27

Magnet Configuration ............................... 3-27

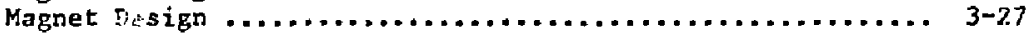

Coil Structural Arrargement ........................ 3-32

Heating Systems (s. A. Freije) :.......................... 3-39

ECRH Systems .................................... 3-41

Sloshing-Ion Neutral-Beam System ................... 3-46

Orift Pump Systems ............................... 3-50

End Cell Shielding (G. E. Taylor) ........................ 3-5I

Penetration Shielding ............................. $3-54$

Large Octopole Shield ............................... 3-54

Small Octopole Shield ............................. 3-56

Choke-Coil shield ................................ 3-56

Halo Scraper/Direct Converter Design

(1. R. Clarkaon, T, E. Luzzi) ...................... 3-56

Design Assumptions and P.equirements ................. 3-57

Plasma Shaping ................................... 3-57

Design Description ................................ 3-57

Materials ........................................ 3-65

Thermal Conditions .............................. 3-65

Sputtering ...................................... 3-73

Coolant-Water Erosive-Wear Hechenism .................. 3-75

Radinlytic Corrosion ............................. 3-76 
Coolant-Line Electrical Insulation ................... 3-79

Tritium Permeation and Inventory in the

Direct-Converter Elements .......................... 3-83

Octopole Nucleonics (J. D. LeE) ........................... 3-83

gadiation Limit ................................ 3-85

Method of Analysis ............................... 3-85

Summary ..................................... 3-96

Electrica). Systems (G. E. Gorker) ......................... 3-96

AC Power System .................................. 3-97

Electrical Power Conversion Systems .................. 3-102

Power Conversion Systems for the

Confinement Magnets ....................... 3-102

Power Conversion fór ECRH, NBI,

and LBI Systems ........................... 3-108

Instrumentstion and Control ......................... 3-110

Tritium Systems (J. R. Haines) ......................... 3-121

References ..................................... 3-125

4.0 Maintenance and Component Replacement ( $P$, $T$, Spampinato) ....... 4-1

Requirements ......................................... 4-1

End Cells ............................................... 4-1

Design Modifications ..................................., $4-7$

Reference ......................................... $4-9$

5.0 Plant Facilities (G. $T$. Busse1) ....................... 5-1

6.0 Cost Projection (H. R. Hamilton)....................... 6-1

7.0 Isgueg (D. C. Lousteau, W. D. Ne1son) ...................... 7-1

Isgue I ................................................ 7-1

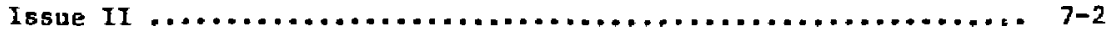


This is the third in the series of reports covering the Fusion Power Demonstration (FPD) design study. This volume considers the FPD-III configuration that incorporates an octopole end plug. As compared with the quadrupole end-plugged designs of FPD-I and FPD-II, this octopole configuration reduces the number of end cell magnets and shortens the minimum ignition length of the central ceil. The end-cell plasma length is also reduced, which in turn reduces the size and cost of the end cell magnets and shielding.

As a continuation in the series of documents covering the FPD, this report does not stand alone as a design description of FPD-III. Design details of FPD-III subsystems that do not differ significantly from those of the FPD-II configuration are not duplicated in this report. The reader is referred to the report, Fusion Power Demonstrations I and II (UCID-19975-1), for system descriptions that are not covered in this document. 
Section 1

\section{Introduction}




\subsection{INTRODUCTION}

This report degcribes the third configuration in the Fusion Power Demonstration (FPD) design study. The device described, FPD-III, is an octopole-plugged tandem-mirror device degigned for a minimum-length, ignited central cell. This design differs from FPD-I and FPD-II, ${ }^{1}$ which were both designed as minimum-length "engineeringmbreakeven" devices.

The FPD-III configuration is the first complete design of a reactor incorporating the octopole end plug. The octopole end plug makes use of $a$ coil set in the plug that generates a four-finned plasta cross section instead of the two-finned shape generated by the quadrupole magnets used in earlier FPD configurations. With the octopole end plugs, the hot plug plasma has a high degree of axisymetry. This is an advantage over quadrupole devices because the transition region between the choke coil and the plug is relatively short. This short transition reduces the central cell lospes and, therefore, reduc es the minimum central cell length for ignition. We reduced the central cell length from $96 \mathrm{~m}$ in FPD-II (a quadrupole design) to $31.5 \mathrm{~m}$ in FPD-III. This dramatic reduction in ignition length would in fact allow us to construct an ignited tandem mirzor device in the existing Mirror Fusion Test Facility (MFTF-B) vault.

The overall FPD-III configuration (Fig. 1-1) is similax to other recent tandem mirror designs. It has a relatively small diameter vacuun vessel, is configured for easy disassembly, and makes use of relatively thin-long solenoid magnets in the central cell. The end cells contain the choke, mirror, and octopole coils. Although the appearance of this end cell is quite different from the quadrupole, all of the plugging, stabilizing, and particle control propertieg are maintained.

The technology assumed for the FPD-III design is gererally of the same level as employed in the two earlier iterations. The main parameters for FPD-III are the following:

Fusion power 142 NTW

Central cell length $31.5 \mathrm{~m}$

Overal 1 machine length

$67 \mathrm{~m}$

Recirculating power

$67 \mathrm{NW}$

First-rall neutron flux

$0.86 \mathrm{MN} / \mathrm{m}^{2}$

Direct capital cost (mid-1984 do1lars) $1080 \mathrm{M \$}$ 


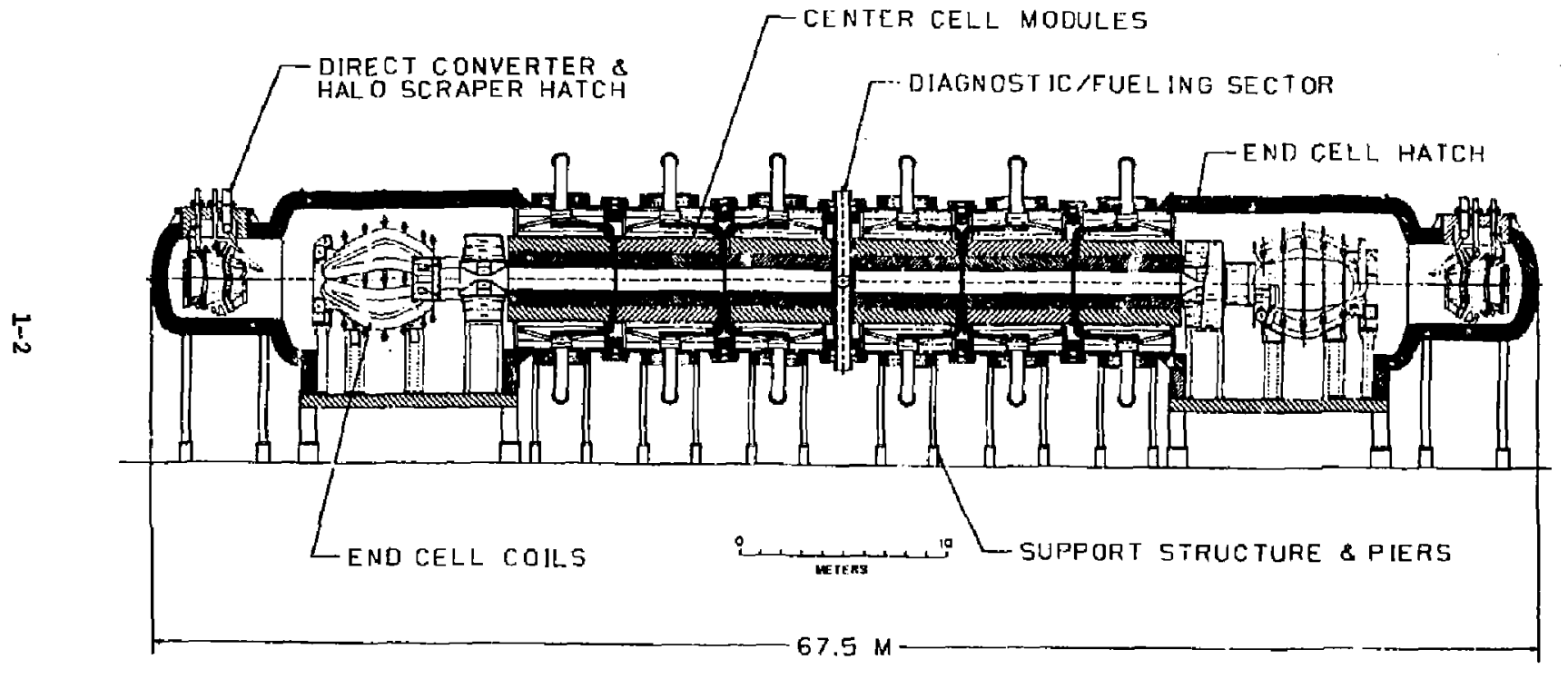

Fig. 1-1. The FPD-III configuration. 
The princips conclusion from the FPD-III design study is that the octopole configuration shows great promise for reducing the size and cost of candem mirror reactors.

\section{REFERENCE}

1. Fusion Power Demonstrations $I$ and II, J. N. Doggett, Ed., Lawrence Livermore National Laboratory, Livermore, CA, UCID-19975-1 (1985). 


\section{Section 2}

\section{Plasma Engineering}




\subsection{PLASMA EMGINEERING}

INTRODUCTION--THE RATIONALE FOR USING OCTOPOLE PLUGS

The plasma engineering tasks for FPD-III were performed to meet the following three design goals:

- The central cell should be ignited, $i . e .$, the power deposited by the fusion alpha particlea in the central-cell plasma volume should balance the total net power lose (leaking charged particles, bremsgtrahlung, and gynchrotron radiation) from that volume.

- The end-cell magnetic configuration should consigt of an octopole coil and an essentially axisymmetric plasma core with magnetohyorodynamic (MHD) stabilization resulting from a combination of the octopole field and a hot electron mantle surrounding the care plasma.

- The ceptral cell length thould be the mimimum capable of attaining ignition, and thereby achieving a minimum-length compact machine.

The previous phases of FPD, FPD-I and -II (Reis, 1,2), employad quadrupole end-cell magnetic configurations in the form of complex double yin-yang sets with recircularizing transition coils. Quadrupole coils provide a well-tested method to achieve a high-beta 4 HD stabilization in both a simple mirror ${ }^{3,4}$ and tandem mirror configuration. ${ }^{5}$ The plasma engineering basis For quadrupole-stabilized tandem-mirror-reactor operation was thorough'y investigated in the Mirror Advanced Reantor Study (MARS). ${ }^{6}$ However, during the final stages of the FPD-II study, we found that quadrupole plugs have two major disadvantages for tandem mirrors whecher ignition test machines or reactors:

1. The end-cell magnet configuration is complex and expensive because a balance in the geodesic curvature of the nonaxisymetric fields is required to 1 imit the radial transport of passing ions. This balance is abiained with a double yin-yang assemb $1 y .6$ 
2. The long characteriatic length of the double quadrupole end-cel1 provides a large plagm volume for the trapping of pasaing ions from the central cell. Therefore, a long central cell is also required to obtain ignition of the central cell plasma, making it impossible to achieve either ignition test machines that are short and compact or power reactors that are economical and small.

It is important to note that FPO-II was configured with quadrupele plugs, ${ }^{2}$ and we were unable to achieve ignition with a central-cell length of less than about $90 \mathrm{~m}$. In contrast to the double quadrupole, the cotopele end-cell configatation proouces an essercialiy axisymetric ead-cell core plesme in an effective solenoidal simple-mirror geometry. In particular, es we will demonstrate below, the shori end-cel! lengths attainable with the octopole geometry enab]e us to arhieve ignition with much shorter ( $330-m$ ) central-cell lengths.

It is interesting to note that the concept of higher order multipole geometries tor fuston plesma confinement is not new. In 1961, for example, Gott et a1., 7 reporter the integration of hexapole windings or a simple mirror experiment. Similarly, at Lawrence Livermore National Laboratory (LLNL) in the ist'y 1960's, .ow-frequency MtD stabilities in the simple mirror machire "ALICE" were effectively suppressed by using addiciongl dodecapole (12-pole) and octopole fields. ${ }^{8}$ Baldwin $^{9}$ investigated higher sirder multipoles to be ased $e$ plugs for tandem mirrors, and Hooper ${ }^{10}$ asfessed the use of octopoles for the Tandem Mirror Experiment (TMX) at LiNl. In addition, Devoto et al., 11 examined the underlying physics, magnetics, and stability issues for the octopole-stabilized tedem mirror. In addition, Perkins et al., 12 developed the conceptual design of MINIMaRS, which is an economical, compact, tandem-mirror reactor with octopole plugs. Therefore, a theoretical and experimental basis exists for the FPD-IIl octcopole end-cell geometry. 
THE PHYGICS BASIS OF FPD-III

The final magnet set selected for FPD-III is shown in Fig. 2-1, and a schematic of the plasma/magnet configuration is shown in Fig. 2-2. In Fig. 2-3, we show the axial diatribution of the magnetic field and plasma potential. Note that because of cancellation symetry, the octopole coil produces a zexo net field on axis. Therefore, as Figs. 2-2 and 2-3 show, the near-axis field diatribution in the end cell is that of a simple mirror formed by the choke coil and outer mirror coils. The solenoid-like turnaround connections of the octopole bers also contribute to the axisymmetric mirror field.

With the important exception of MHD and radial transport, the physics basis of the core plasma in FPD III is analogous to that of previous thermal-barrier tandem-mirror machines (for example, see Ref. 6). The radial pressure of the deuterium-tritius (DT) fuel ions in the 31-m long central cell is contained by the 2.5-T solenoidal field, whereas the axial pressure is contained mainly by the high-field (24-T) choke coils at each enú. Similarly, nearly a11 the 3.5-MeV fusion alpha particles are born mirror trapped in the central cell. A amall fraction $(<10 \%)$ of the central cell ions pizch angle scatter into the loss cone, pass into the octopole end cell, and then reflect oft the positive plugging potential and return through the central cell. The magnitude of the potential peak $(>200 \mathrm{iV}$ relative to the central cell potential--see Fig. 2-3) reduces the centralwcell ion end loss sufficiently to allow fusion alpha heat:ing to sustain regidual central-cell energy losses that mainly resutt from end-cell ion trapping. Therefore, the central cell is ignited. The MHD stability of FPD-III is obtained by means of the octopole field and a mirror-confined hot-electron mantle.

In acdition to the ion-confining potential poak in the end cell, an intervening "thermal barrier" 15 is required to moderate electron heat conduction from the peak and, therefore, to reduce end-cell electran-cyclntron resonant heating (ECRH) power. A depression in the end-cell ion density is formed by microstable sloshing ions fueled at each end by a $475-\mathrm{kV}$ negative-ion neutral-beam source. Mirror-trapped hot electrons sustained by ECRH heating at the uidplane of the sloshing ion distribution provide the 


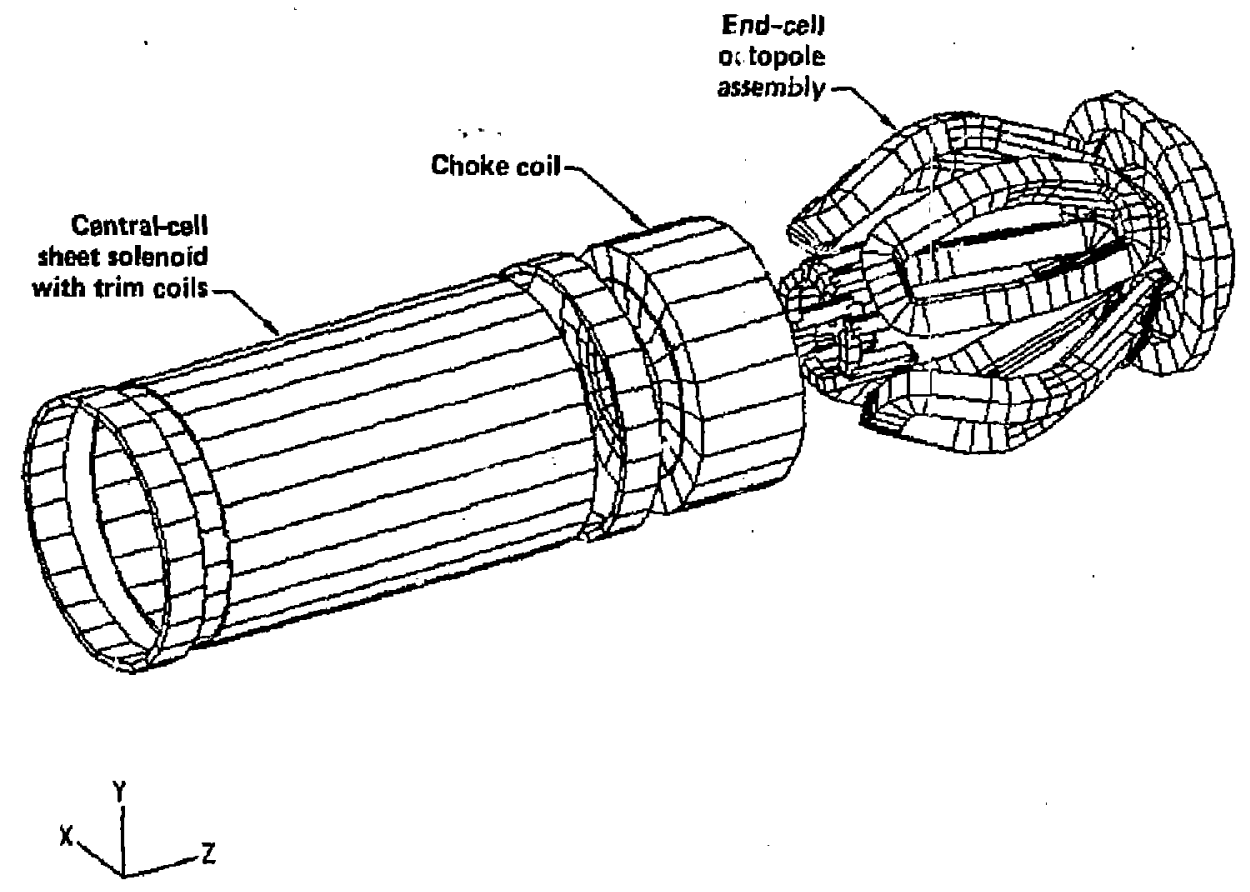

Fig. 2-1. The FPD-III magnet set (only ope of the central-cell sheet solenoids is shoun). 


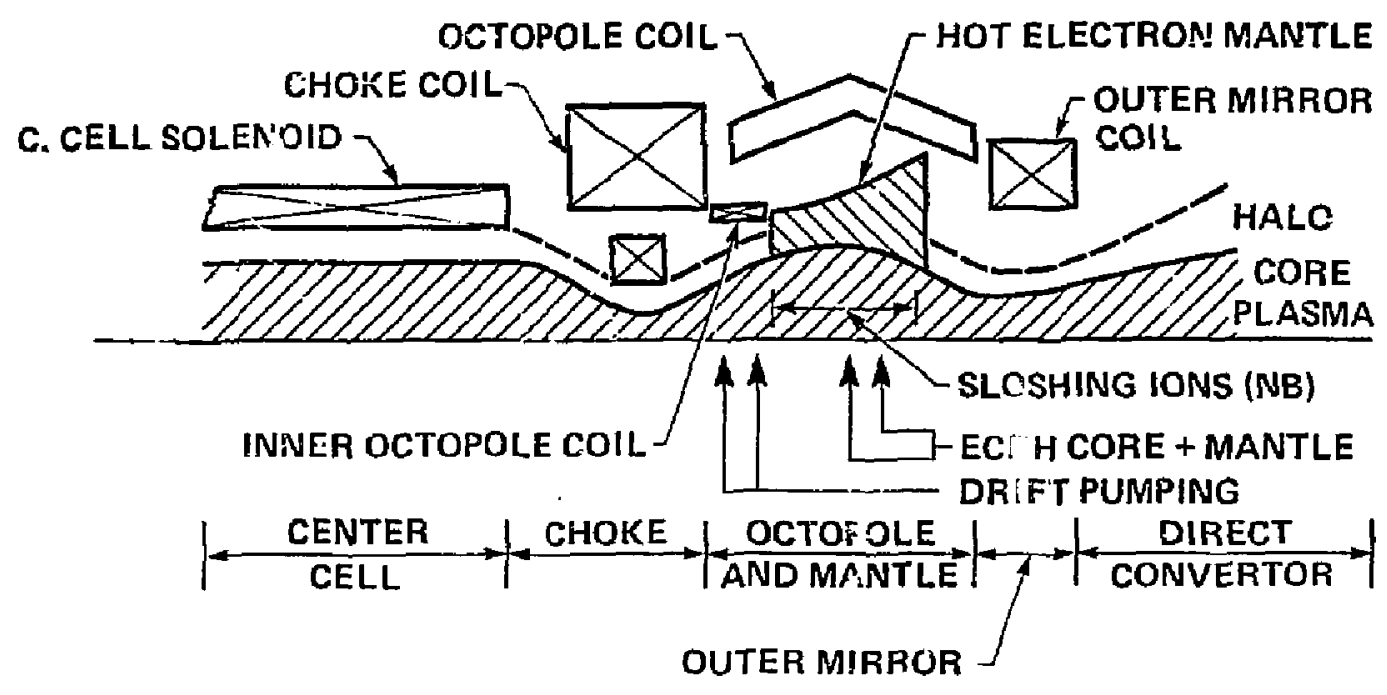

Fig. 2-2, Schewatic of the FPD magnet and plasma configuration. The split obter-mirror soienoids are represented by a single coil in this figure. 


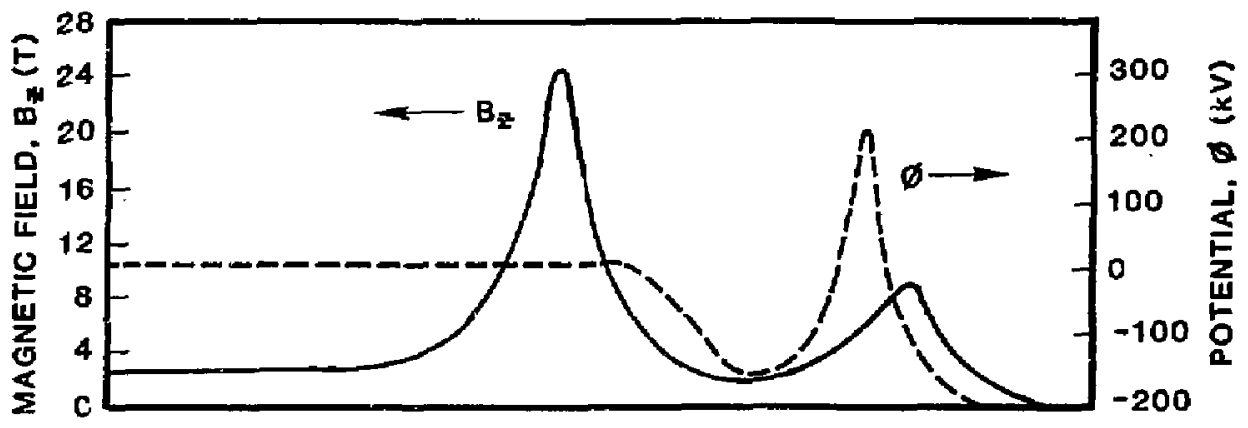

Fig. 2-3. Axial distribution of magnetic field and plasma potential. 
negative potential (approximately $-186 ; v$ relative to the central cell) required for the thermal barrier (Figs, 2-2 and 2-3).

$A$ list of the principal plasma engineering parameters for FPD-III is given in Table 2-1.

THE OCTOPOLE MAGNETIC CONFIGITATION, MHD STABILITY, AND THE HOT ELECTRON MANTLE

Figure 2-4 shows an isometric view of the FPD-III octopole end-cell magnet set. The main outer octopole coil, located between the high-field choke coil and the outer mirror solenoid, is composed of four discrete window-frame coils and represents the culmination of a detailed atudy of optimum winding geometries. ${ }^{13}$ The discrete coil version of the actopole coil is preferred over a continuous-wound single-octopole coil because of better winding convenience and ease of maintenance. However, unlike the continuoub-wound octopole, the turnaround connections at the outer end of the discrete octopole coil carry bolenoidal-1ike currents that buck the main solenoid fields and contribute to problems in obtaining a sufficient mirror ratio in the mantle. Accordingly, the outer mirror field is formed by a split stefped solenoid that also concels these deleterious bucking currents. Details of the magnet configuration are given in Table 2-2.

The conventional quadrupole magnetic geometry (e.g., the yin-yang coil pair) is characterized by a minimum-lBI region at the center of the configuration and a field that increases in all directions awey from this minimum. However, for higher order multipoles with order $N$ greater than four, the minimum I Bl occurs off the central axic with a period $\cos (N \theta / 2)$. In addition, the near-axis multipole field componen's decrease with increasing $\mathrm{N}$, thus the higher the number of multipole bars, the more axisymetric the near field will be. Because of access requirements, the number of conductor bars thet can be placed around the azimuthal circumference is limited, we have selected an octopole $(N \neq B)$ configuration for FPD-III. In principle, the use of hexapole coils $(N=6)$ is possibly more advantageous because of less complex winding and improved access, although increased radial transport requirsa greater attention to detail in the design of the magnet set. ${ }^{14}$ 
Table 2-I. Principal plasma parametera for FPD-III.

\section{General}

Fusion power (MW)

Neutron wall loading $\left(\mathrm{MH} / \mathrm{m}^{2}\right)$

Q

Qeng

Cold fueling curtent (A)
141.7

0.86

11.9

$\$ 1$

81.3

$2.50^{\circ}$

24.0

1.50

8.57

1.30

31.5

0.45

0.666

44.0

30.2

$2.52 \times 10^{14}$

$6.02 \times 10^{14}$

0.6

Quartic

0.021 
Table 2-1. (continued).

End ce11

\begin{tabular}{|c|c|}
\hline Length $(m)$ & 8.05 \\
\hline Average midplane beta & 0.220 \\
\hline Ion confining potential ${ }^{a}(\mathrm{keV})$ & 205.5 \\
\hline Barrier potential ${ }^{a}(\mathrm{keV})$ & 186.0 \\
\hline Electron confining potential ${ }^{a}$ (kev) & 203.3 \\
\hline Trapping current (A) & 61.2 \\
\hline Passing density at $b\left(\mathrm{~cm}^{-3}\right)$ & $1.57 \times 10^{12}$ \\
\hline Peak-to-midplane sloshing-ion density ratio & 2.83 \\
\hline $\mathrm{g}_{\mathrm{DT}}$ & 1.96 \\
\hline$g_{\alpha}$ & 4.23 \\
\hline Int electron energy at $b(\mathrm{keV})$ & 411.2 \\
\hline Warm electron energy at a (kev) & 201.9 \\
\hline Absorbed ECRH power at $a^{b}$ (WW) & 0.160 \\
\hline Absorbed ECRH power at $b^{b}(M W)$ & 5.42 \\
\hline Absorbed neutral beam power ${ }^{b}(M w)$ & 0.132 \\
\hline Neutral beam trapping fraction (MW) & 0.082 \\
\hline
\end{tabular}

Hot electron mantle

Average beta

0.692

Hot electron mirror ratio

2.0

Hot electron energy (keV)

850

absorbed ECRH power ${ }^{b}$ (MW)

6.22

Disisipated synchrotron power ${ }^{b}$ (MW)

4.49

Dissipated scattered power (MW)

1.41

Dissipated drag power (MW)

0.308

Total mantle volume $\left(\mathrm{m}^{3}\right)$

28

${ }^{a_{\text {Measured }}}$ relative 0 the central cell potential.

$b_{\text {Total-moth ends. }}$ 


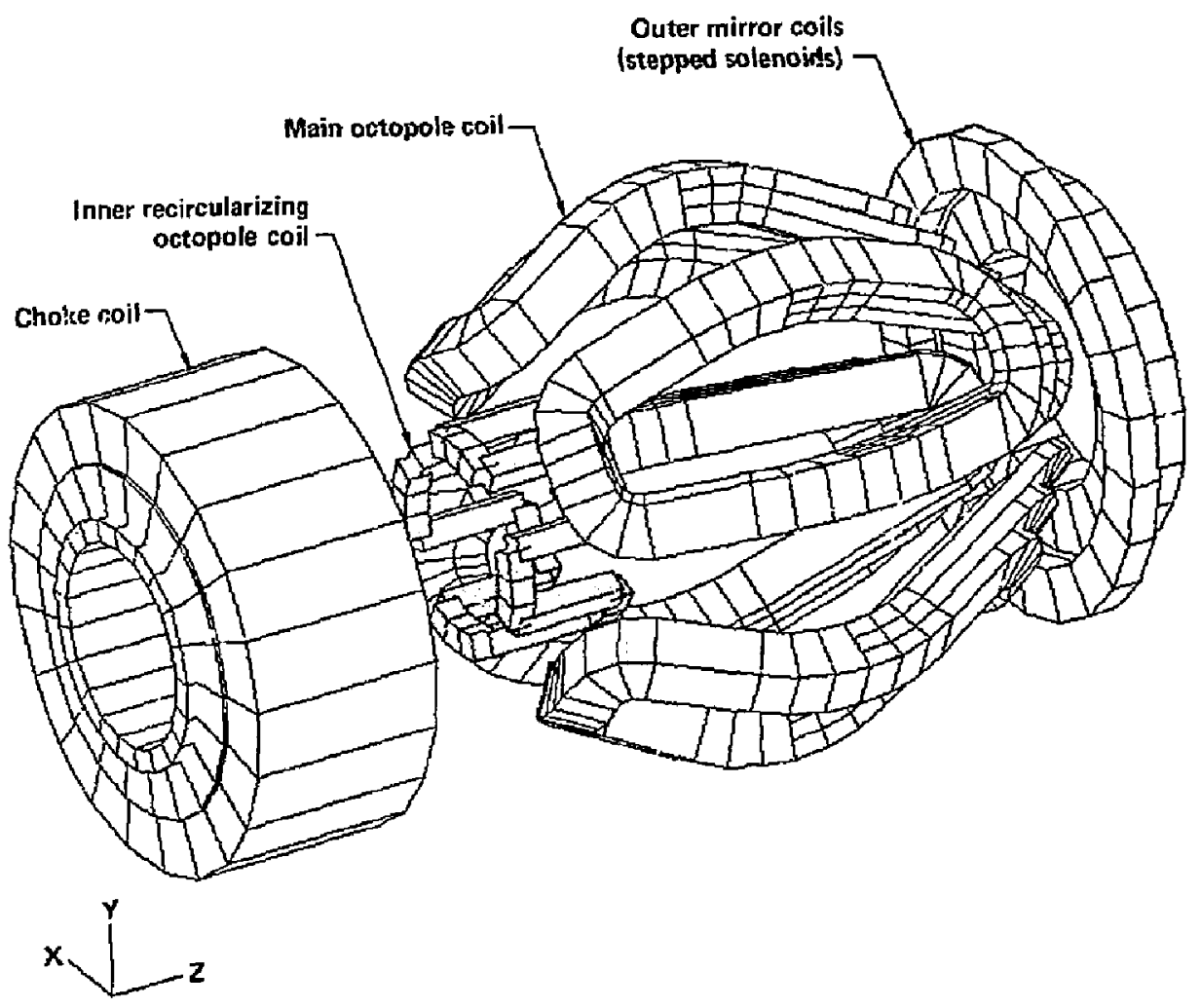

Fig. 2-4. The end-cell octopole magnet set. 
Table 2-2. End-cell magnet parameters.

Axial Fields (T)

Choke coil

24.0

Midplane

1.5

Outer mirrar

8.57

Mantle (minimum)

1.3

Choke coil

Superconductor

Superconductor pack dimensions $\Delta z \times \Delta \mathrm{r}^{\mathrm{a}}$ (m)

$\mathrm{Nb}_{3} \mathrm{SaTi} / \mathrm{Nb}_{3} \mathrm{Sn} / \mathrm{Nb} \mathrm{Ti}$

$1.709 \times 0.517$

$1.775 \times 0.449$

Superconductor pack current densities ${ }^{a}\left(A / D^{2}\right)$

$1.975 \times 0.196$

$2.48 \times 10^{7}$

$1.80 \times 10^{7}$

$1.65 \times 10^{7}$

Normal-condustiag insert dimensions $\Delta z \times \Delta r(m)$

$0.6 \times 0.39$

Normal canducting insert current density $\left(A / m^{2}\right)$

$2.48 \times 10^{7}$

Normal conducting insert power consumption (MW)

12

Normal conducting insert field contribution ( $T$ )

8

Normal conductor material

AMZIRC

Large octopole coil

Configuration

Diacrece four-frame octopisle

Winding pack dimensions (m)

$0.48 \times 0.48$

Current density $\left(\mathrm{A} / \mathrm{m}^{2}\right)$

$2.5 \times 10^{7}$

Superconductor

$\mathrm{Nb}_{3} \mathrm{Sn}$

Mean radius at midplane (m)

2.29

Axial length of assembly (m)

3.68 
Table 2-2. (continued).

Quter mirror coil

Configuration

Split solenoid ${ }^{b}$

Winding pack dimensions $c(m)$

$0.25 \times 0.47$,

$0.5 \times 0.57$

Mean radius (m)

1.61

Current density ${ }^{c}\left(\mathrm{~A} / \mathrm{m}^{2}\right)$

$5 \times 10^{7}$

$5.5 \times 10^{7}$

Supercondu =tor

$\mathrm{Nb}_{3} \mathrm{Sn} / \mathrm{NoTi}$

Three stacked solenoida.

bo cance? octopole turnaround bucking currents.

ctwo split solenoids. 
The magnitude of the octopole field relative to the solenoidal mirror field is varied by adjusting both the radial position of the octopole bars and the pack current density, thus placin the minimum $|B|$ outside the core plasma-flux bunde that maps from the central cell. Wre adjust the position and current of the small inner octopole coil (Fig. 2-4) to cancel any asymecry of the core plasma at the midplane of the large octopole resulting fron the residual octopole fields. This has the effect of substantially reducing the radial deflection of passing ions in the plug. 11 Appropriate configuration of this inner-trim octopole coil can ensure that confinement times, resulting from ion radial transport in the octopole geometry are much larger than the characteristic times for trapping (and pumping) in the end plug.

The radial profile of the magnetic field at the midplane of the octopole plug is shown schematically in Fig. 2-4. Note that |B| decrenses with radius from the axial value to a local minimum and then increases as the coils are approached. We can state the condition for flute interchange stability of our system in terms of an integral along an entire flux tube as

$$
\int \frac{1}{R_{c} r B^{2}(r)} \frac{\partial p}{\partial \psi} d 1<0,
$$

where $R_{c}$ is the vacuun field radius of curvature and $\partial P / \partial \psi$ is the gradient of the ranial pressure profile with respect to ragnetic flux $(\psi=f \mathrm{~B} \cdot \mathrm{da})$. Now our core plasma can be considered to be situated in two axisymetric mirror regions, i.e., the central cell and end cell (Fig. 2-3), where the $1 / \mathrm{rB}^{2}(x)$ weighting always favors the bad curvature drive to the stability integral over the good curvature regions under the mirror coils. Moreover, our core plasma has a quartic pressure profile so that $(a p / \partial \psi)$ core $<0$ (this behavior at the midplane of the plug is illustrated in Fig. 2-5). Therefore, it is impossible to saisfy Eq. (1) for the core plasma alone. Accordingly, we arrange for the region between the core plasma and the minimum IBI region in the end cell to be filled by 3 mantle of hot mirror-confined electrons suctained by a separate ECRH system. The added plasma pressure here must be able to form a sufficiently large positive pressure gradient out to the finimum $|B|$ point to ensure that the 


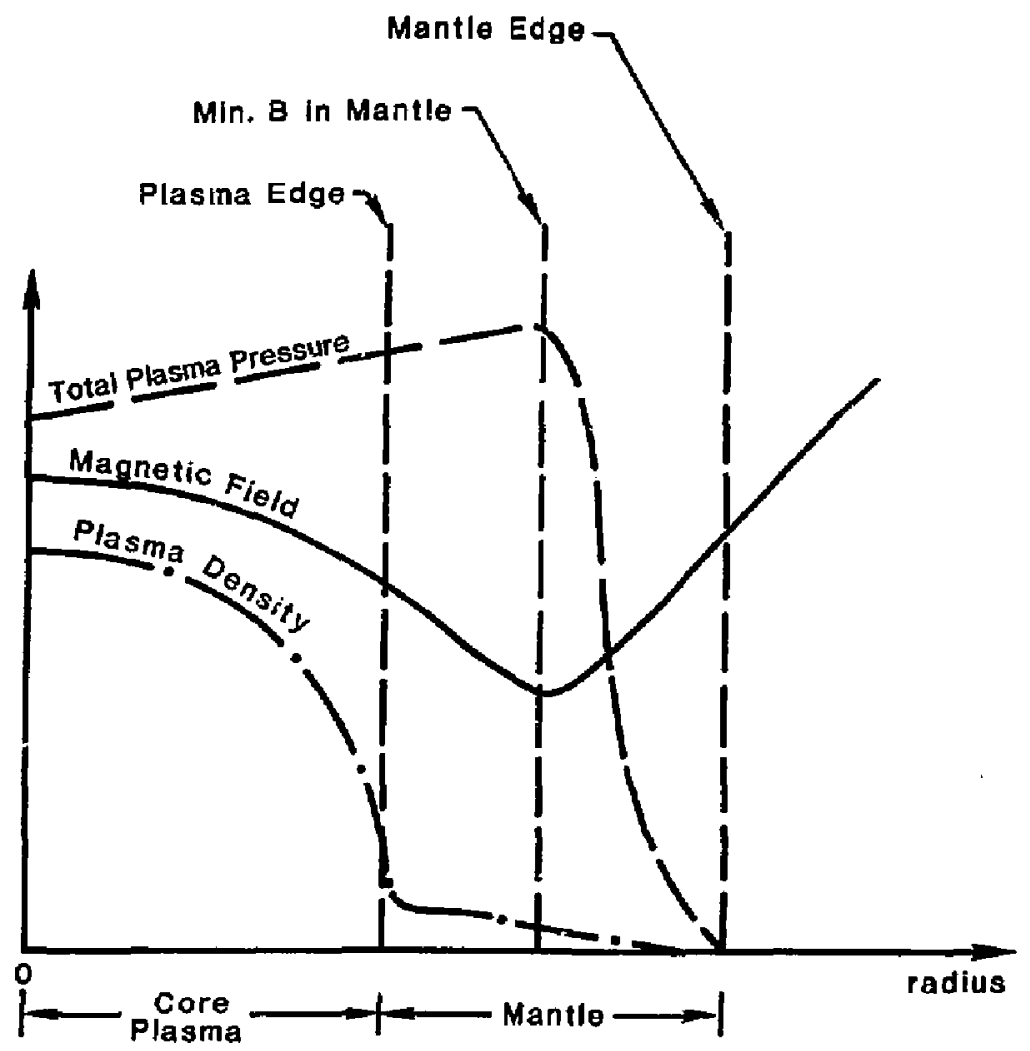

Fig. 2-5. Schematic radial profiles in the end plug. 
mantle, of limited axial extent, satiafies Eq. (1) evaluated over the entire axial extent of the flux tube.

At radii greater than that of the minimum IBI point, the mantle pressure can be allowed to fall to zero because this is now a good curvature region (Fig. 2-5). With suitable choices for pressure functiona in the oyotem, Eq. (1) can be solved for the required minimum mantle beta. We employed the results of Devoto et al., ${ }^{11}$ which, for a similar magnet set, showed that the required peak mantle beta $\left(\hat{\beta}_{m}\right)$ could be expressed as a linear combination of the central-cell and end-cell betas $\left(\hat{\beta}_{c}, \hat{\beta}_{b}\right)$ as

$$
\hat{B}_{m}=1.2 \hat{B}_{b}+0.56 \hat{B}_{c} \text {. }
$$

Stabilizy against in:-rchange does not, of course, ensure stability to ballooning modes at high $\beta$. However, finite Larmor radius (FLR) phenomena are expected to stabilize all ballooning modes except for $m=1$. Calculations of this mode in quadrupole-stabilized tandem mirrors have yielded beta linits very close to those predicted by interchange criteria. ${ }^{11}$ The MHD analysis for octopole geometries at high $\beta$ is an important on-going research area. ${ }^{15}$

Although the end-cell core plasma is essentially axisymmetric, the mirror-confined hot-electron mantle surrounding the core plasma exhibits the characterigtic four-pointed convoluted shape of the octopole field far from the axis. Moreover, the mantle occupies magnetic field lines that do not map through the machine; therefore electron scattering losses from this mirror region appear as surface heat loads on the surrounding shielding walls that are located under the large octopole coil. To limit both anisotropy-driven microinstabilities of the hot electrons and mantle ECRH-power requirements, we specify a mirror ratio of two or more for all field lines that pass through the mantle region. In addition, the mantle electrons must respond as an wHD fluid, not as a rigid bady, to MHD instabilities in the core plasma and, therefore, must exhibit drift frequencies less than the characteristic MHD growth rate. Further details of the physics requirements for our nentle electrons are given in Ref. 11. 
As we indicated previously, the mejor raison d'etre for the octopole end cell is that it enables ignition fur a tandern mirror to be acnieved with much shorter central cell lengths. The condition that must be met for ignition of a tandem mirror reacto: is that the power deposited by fusion alpha particles in the central cell plagma tmat be greater or equal to all sources of power loss from this volume. Passing centrdl-cell ions that undergo collisional t-apping in the end cell between the potential peak and the choke coil inoznetic field peak (see Fig. 2-3) must be removed (or "pumped") at the rate at which they trap, otherwise the end cell would fill with trapped ions and the thermal barrier would be destroyed. To provide this pumping in FPD-III, we configured drift-pump coils above and below the plagma in the end cell and effected a resonance between tive coil frequency and the bounce frequency of the trapped 'ions. The resulting enhanced radial diffusion transports these ions to the unplugged halo plasme surrounding the core plasma, where they are swept to the grounded helo dumps at the ends of the machine.

The ion-trapping rate (and thus drift-pump loss rate) of ions in the end cell scales as the end-ceil plasma volume, the square of the end-call ion density, and the inverse of the central-cell ion temperature to the three-halves power. Drift pumping of trapped ions in the end cell represents the major power-loss mechanism from the central ecli plasma (other losses such as axial ion losges and radiation losses are typically less than $10 \%$ of the tota1), thus we can represent the central-cell ignition condition as

$$
r_{c}^{2} L_{c} P f_{\alpha} \geq c r_{e c}^{2} L_{e c} n_{e c}^{2} T_{c}^{-3 / 2}+s,
$$

where ${ }^{\prime}{ }_{c}, I_{c}, t_{e c}$, and $L_{a c}$ are the radii and lengths of the plasma in. the central cell and end cell, respectively; $P$ is the central-cell fusionpower density; $f_{\alpha}$ is an alpha-confinement factor (see below); $n_{e c}$ is the end-cell ion density; $T_{c}$ is the central-cell ion temperature; $c$ is $a$ constant; and $S$ represents the amall subsidiary centra1-cell losses (e.g., radiation losees). The implication of Eq. (3) is clear: as the length (and thus volume) of the end-cell magnetic configuration increases, the dimensions 
of the central cell plasma must increase so that fusion alpha power can make good the power losses reaulting from increased trapping in the end cell. At this point, one is justified in asking why we cannot simply increase - central cell radius $r_{c}$. With this increase we could meet the ignition criteria with a corresponding reduction in the length $\mathrm{L}_{c}$ that would result in a short compact machine. However, in addition to ignition, a second important deaign criterion exists that must be met. This criterion is conservation of magnetic flux mapping through the machine, i.e.,

$$
\pi r_{c}^{2} B_{c}\left(1-\left\langle\beta_{c}>\right)^{1 / 2}=\pi r_{e c}^{2} B_{e c}\left(1-\left\langle\beta_{e c}>\right)^{1 / 2}\right. \text {, }\right.
$$

where $B$ represents the vacuum fields, and the beta corrections are applied to account for the plasma diamagnetism at high beta. Therefore, assuming that end-cell magnetic fields $B_{\text {ec }}$ are maintained at their economical maximum, an increase in central cell radius must be matched by a corresponding increase in end-cell radius $r_{\text {ec }}$. Furthermore, accommodation of this increasing end-cell plasma radius by corresponding increases in the end-cell solenoid radii means that the axial distance ( $\mathrm{L}_{\mathrm{ec}}$ ) between the solenoids must be increased to preserve the required mirror ratio. Accordingly, increases in both $r_{\text {ec }}$ and $L_{e c}$ result in further increases in end-cell trapping volume; this in turn requires a greater central cell length to meet the ignition criteria according to Eq. (3).

Note also that we cannot minimize end cell volumes by simply reducing the end-cell plasma radius $r_{\text {ec }}$ to arbitrarily small values. By applying Eq. (4), this would result in small valtes of the central-cell radius $r_{c}$ with detrimental effects to alpha-deposition efficiency. In our high-beta, low-field central cell, the gyroradius of the 3.5-MeV fusion alpha particle is typically an appreciable fraction of the plasma radius. Further reductions in plasma radius would result in delaterious alpha absorption by the halo outside the core plasma, with a resulting decrease in the alpha-confinement parameter $f_{\alpha}$ in Eq. (3). Further details on alpha lose to the halo follow in the next section.

Here then lies the problem with end-cell magnetic configurations such as the FPD-I and -II quadrupoles that have long characteristic lengths. A long 
end-cell length requires a long central cell for ignition making it impossible to achieve a short ignition machine. By contrast, the octopole provides a method for obtaining a short end-cell configuration rith the minimum end cell length $(27 \mathrm{~m})$ determined only by alobhing-ion adisbaticity. This principle is illugrrated in Fig. 2-6 where we compare the nagnetic configurations for minimum-1ength ignition machines that are based on the quadrupole (FPD-II) and octopole (FPD-III) end cell geometrisa, respective1y. In Table 2-3, we compare the major physics parameters for the two machines. Note that FPD-II with a characteristic trapping length in the quadrupole end cell of $\sim 14 \mathrm{~m}$ requires a central-cell ignition length of $290 \mathrm{~m}$, whereas FPD-III with its short octopole end cell and short characteristic trapping length of $15.6 \mathrm{~m}$ can ignite in a central-cell length of only $31 \mathrm{~m}$.

HALO AND DIRECT CONVERTER PHYSICS

As noted above, the trapping and purping of ions in the end cells represents the major power loss from the central cell. Therefore, for our ignition condition to hold, the axial ion loss must be held to a amall fraction of the radial drift-pump loss. In FPD-III, Lhis requirement necessitates a large electrostatic plugging potential ( $\phi_{c}$ ) of $205 \mathrm{kV}$ (see Fig. 2-3). Clearly, for the plasma to remain neutral, the total current of ions leaving the machine must equal the electron loss current. Accordingly, most of the ions diffuse radially through drift pumping to the edge of the core plasma where they penetrate the radially decreasing confining potential and then flow axially to the grounded halo scraper at the ends of the machine (see Sec. 3). By contrast, the electron radial loss is small so that virtuglly afl of the electron loss current flows axially to the direct converter, which is biased at $\phi_{\mathrm{e}}=-203 \mathrm{kV}$ relative to the central cell. Accordingly, directly-converted electrical power is available from the electron channel, whereas only thermally converted power is available from the ion loss channel to the grounded halo scraper.

The central cell plasma is surrounded by a halo plasma. This halo is deliberately enhanced by recycling most of the iors at the end dumps to provide a shield around the core plasma to protect against gas and 


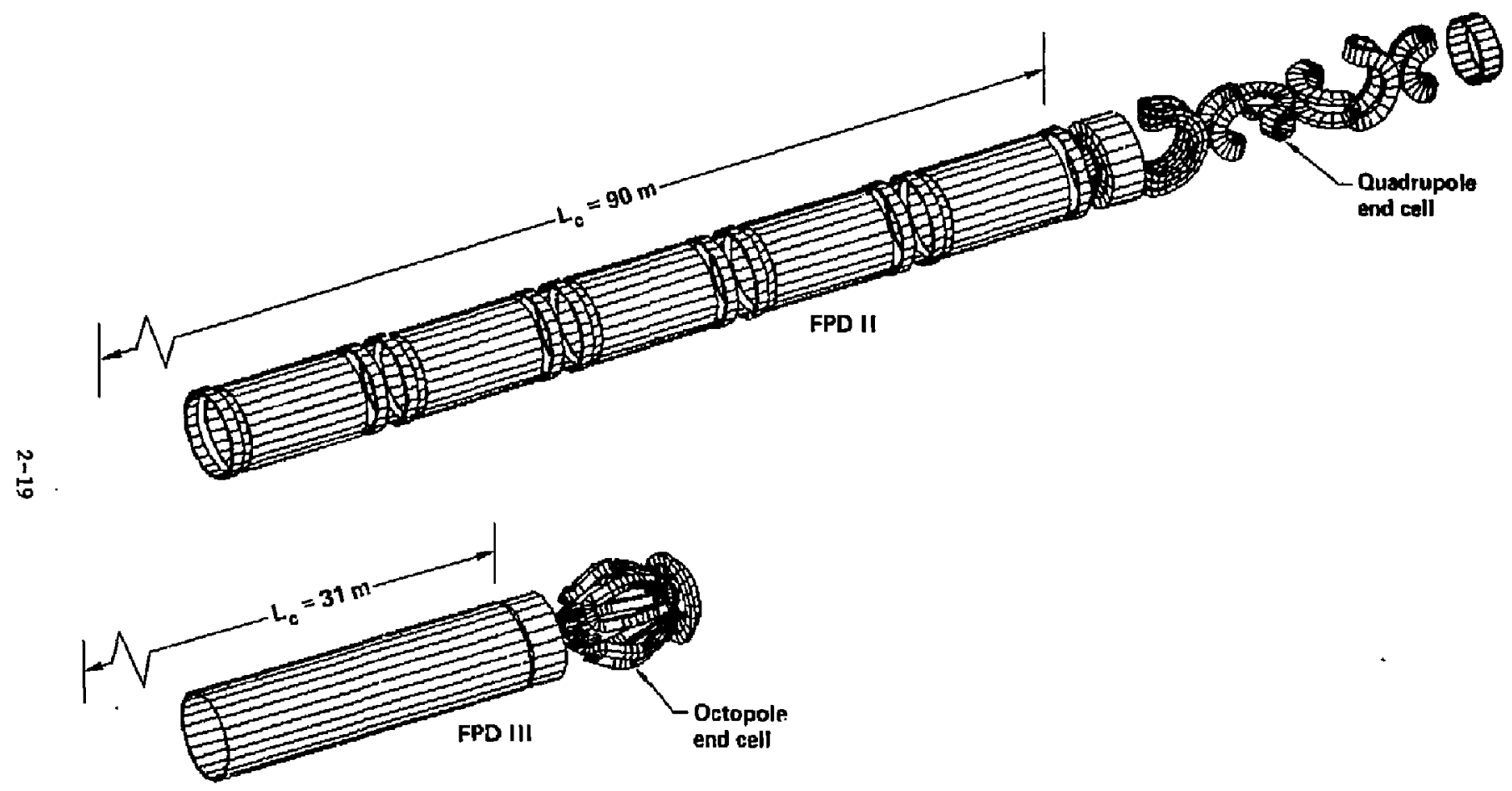

Fig. 2-6. Comparison of the magnet sets for FPD-II and FPD-III aligned at the midplane of the central cel1. Note that the much shorter end-cell length for FPD-III resules in a considerably shorter centra1-ceil ignition length. The discrete central-cell solenoids for FPD-III cre represented, in this figure, by a continuous-sheet solenoid. 
Table 2-3. A comparison of plasma parameters for FPD-II and FPD-III.

\begin{tabular}{|c|c|c|}
\hline End-cell configuration & $\frac{\text { FPD-II }}{\text { Double }} \begin{array}{c}\text { quadrupole } \\
\text { (yin-yang) }\end{array}$ & FPD-III \\
\hline Minimum centrai-cell length for ignition $(\pi)$ & 90 & 31 \\
\hline Characteristic end-cell length (m) & $\imath_{20}$ & 28 \\
\hline End-cell particle trapping length $(m)$ & 13.6 & 5.4 \\
\hline Neuiron wa1i loading $\left(\mathrm{MW} / \mathrm{m}^{2}\right)$ & 1.0 & 0.9 \\
\hline Q & 37 & 12 \\
\hline Absorbed heating powers in end cell (MW) & 12.8 & 11.9 \\
\hline
\end{tabular}


impurities. To act as a shield, the balo density must be about $5 \times 10^{12} \mathrm{~cm}^{-3}$ and the electron tenperature above $30 \mathrm{eV}$. These values ensure that the mean free path for ionization of any impurity vill be wuch shorter than the thickness of the halo. Impuritiea coming from the walls, vacuum leaks, or sputtering are ionized in the halo plasma and then flow along the magnetic field lines to the grounded halo dumps aituated outaide the halo scrapers at the ends of the machine. Thermal conversion of this power ig also possible.

Table 2-4 summarizes the power flows to the ends of the machine. Note that, for computational simplicity, FPD-III is configuked with only one direct converter region. Recent results for the Tanden Mirror Experiment (TMX-U) at LLNL ${ }^{5}$ indicate that suppression of central-cell radial transport could be achieved by partitioning the direct converter into a number of radial zones.

The halo surrounding the plasma core requires power to maintain the electron temperature against both thermal conduction along the field to the ends and gas-ionization losses. In FPD-III, the halo electrons are heated by a drag on the alpha particles with orbits that pass through the halo. Although the density in the halo is lower than in the core, drag is much otronger in the halo because the electron temperature is low. Any alpha that spends much time in the halo transfers most of its energy to the haio electrons. This process aupplies the power needed to majntain the halo, but it also represents a drain on alpha power that would otherwise be available to heat the core plasma and maintain the temperature needed for ignition [i.e., a reduction in the factor $\overline{\mathrm{r}}_{\alpha}$ in $\mathrm{Eq}$. (3)]. In the following section, we discuse the modeling of the alpha energy loss to the halo, thereby providing important information on the central-cell ignition condition discussed above.

ALPHA-PARTICLE ENERGY LOSS TO THE HALO PLASMA

To evaluate the power transferted to the halo, we used two different computer coded. ${ }^{16}$ The Eirst code follows slphe particle orbits in an axially symetrical magnetic field that can vary with radius. In a tandemmirror central cell, the field is a function of radius because the diamagnetic effect of the plasma at high beta reduces the field more near the axis than farther out. In the long, thin central cell, the field reduction is given $b_{j}$ : 
Table 2-4. Power flows to the end tank (powerg are for both ends).

Core plasma power leakage, $P_{c}$ (MW) 22.37

Power leakage to halo scraper, $\mathrm{P}_{\mathrm{hs}}(\mathrm{MW})$ 2.41

Power leakage to halo dump, $P_{\text {hd }}$ (KW)

Directly corverted electric power fron core plasma, $E_{\mathrm{dc}}(\mathrm{MW}) \quad 14.19$

Thermally converted electric power, ${ }^{a} E_{t h}$ (MW) 5.71

Direct conversion efficiency, $E_{d c} / P_{c} \quad 0.63$

Overa11 electric conversion efficiency,

$$
\left(E_{t h}+E_{d c}\right) /\left(P_{c}+P_{h s}+P_{h d}\right) \quad 0.65
$$

af supplied to a thermal cycle at $35 \%$ assumed efficiency. 


$$
B(r)=B_{c}[1-\beta(r)]^{1 / 2},
$$

where we assume that beta has the same radial dependence as density, and therefore takes a quartic variat::on

$$
\theta(r)=\hat{B}\left(1-r^{4} / r_{c}^{4}\right) .
$$

Here, $\hat{\beta}$ is the peak beta on axis. The code records the time the alpha spends in each of several radial zones in the halo and the time in the core plasma. The total solid angle is divided into maty (usually 20) equal increments; an orbit starts with its initial velocity vector pointing into each increment. This process is repeated as the starting point is stepped along in radius. At each starting point the effect is weighted in proportion to the production rate of alphas at that location. Finaliy, tive average time spent by all of the alphas in each radial zone and the orag time $\tau_{d}$ for alphas in each radial zone are used to calculate the energy transferred to each zone. The drag time is given by the following:

$$
\tau_{d}=2.8 \times 10^{12} \frac{T_{e}\left(H_{\alpha}\right)^{1 / 2}}{n_{e} \ell_{n} \Lambda_{e} \in\left(\frac{W_{\alpha}}{7340 T_{e}}\right)^{1 / 2}}
$$

with time measured in seconds, energy ana temperature in $\mathrm{eV}$, and density in $m^{-3}$. The function $G$ is given by

$$
G(x)=\frac{1}{x} \operatorname{erf}(x)-\frac{2}{\sqrt{\pi}} e^{-x^{2}} .
$$

Using this drag time, we calculate the power transferred in the kth zone as

$$
P_{\alpha, k}=P_{\alpha} G_{k} T_{d c} / \tau d k \text {, }
$$

where $P_{\alpha}$ is the total alpha power; $G_{k}$ is the average fraction of the time spenc by all alphas in zone $k_{i}$ and $\tau_{\mathrm{dk}}$ and $\tau_{\mathrm{dc}}$ are the drag times in the zone and in the core plasma, respectively.

Two effects are ignored by this code, but this does not appear to be a serious deficiency because these two effect $s$ tend to cancel each other. The 
first effect is that the code does not allow the orbits to shrink as the alpha loses energy. If the drag were uniform at all points around the orbit, the orbit would tend to shrink toward its guiding center. The orbit would finally reach a size where it no longer passed through the halo, and drag in the balo would end. But, the second effect cancels the first because the drag is greater on one side (the halo gide) than thi other; therefore, the guiding center should tend to drift toward the side of greater drag. This effect. would tend to keep the orbit in contact with the halo.

Our second computer code uses a Monte Carlo technique to calculate the drag at each different radial position, including the halo. It allows the density and temperature profiles to be specified. It follows the orbits as they shrink and as the guiding centers drift while the alphac lose energy. The results from this code confirm the results obtained with the first code, although both give statistical variations. The results from the orbit code vary somewhat, depending on the starting and ending points of the trajectories. The Monte Carlo code is very sensitive to the assumed radial profiles of density and temperature.

Figure 2-7 shows the first part of some typical alpha trajectories in the central cell of FPD. In Fig. 2-7(a), the perpendicular energy is $3 / 4$ of the full initial $3.52 \mathrm{MeV}$, and the alphas were born at a radius of $0.25 \mathrm{~m}$. Figure 2-7(b) shows orbits with $1.5 \mathrm{MeV}$ of perpendictlar energy that were started at $0.35 \mathrm{~m}$. Notice the variation of the curvature of the orbits, indicating the radial variation of the magnetic field. Figures like this cannot show the large fraction of the alphas that do not pass through the halo. Many alphas, even those created near the halo, do not pass through it because of the initial direction of their velocity vector. The initial direction determines both the component of velocity perpendicular to the field Iines and the radial excursion for a given perpendicualr velocity. Also, the production of alphas is greatest near the axis and falls off rapidly near the halo. For these reasons it is difficult to estimate the loss to the hato without a rather detailed calculation. Unfortunately the alpha particles that are born with their velocity vectors within the loss cone and are, therefore, lost promptly are not the ones that would have lost their energy to the halo. The two losses are therefore additive. 


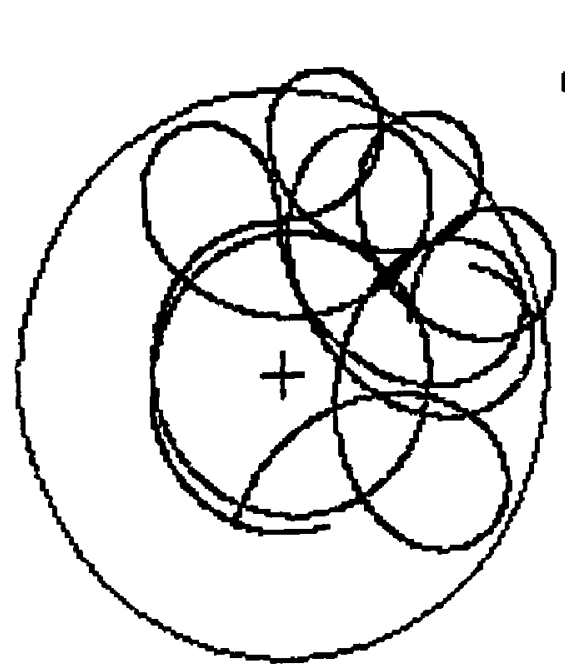

(3)

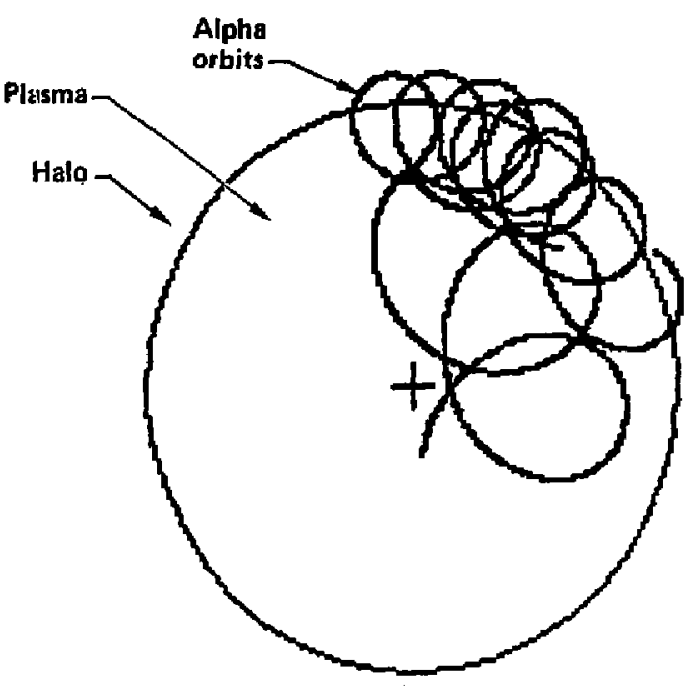

(b)

Fig. 2-7. Alpha orbits in the FPD-III central-cell plasma. The large circle is the boundary of the core plasma at $r_{c}=0.45 \mathrm{~m}$. (a) $W_{\alpha \perp}=2.64 \mathrm{MeV}$, $\tau_{\text {start }}=0.25 \mathrm{~m}$; and $(b) W_{\alpha \perp}=1.5 \mathrm{MeV}, r_{\text {start }}=0.35 \mathrm{~m}$. 
Figure 2-8 shows a graph of the power lost to the halo plotted against a parameter $P$ that is proportional tu the ratio of alpha gyroradius to the plasma radius. This particular gytoradius used in the parameter $P$ was chosen empirically to make the plot a univeraal curve. Accordingly, a gyroradius corresponding to full energy in the perpendicular direction and a plama beta equal to half the peak value gave points that all fell near a smooth curve. We therefore define $P$ as

$$
P=\left[x_{c} B\left(1-\frac{1}{2} \hat{B}_{c}\right)^{1 / 2}\right]^{-1},
$$

where $r_{c}$ is the plasma radius in meters, $B_{c}$ is the vacuum central-cell magnetic field in tesla, and $\hat{\beta}_{c}$ is the peak value (i.e., on axis value) of plasma beta. Although the points shown in Fig. 2-8 were calculated with different peak beta, different vacuum magnetic field, or different piasma radii, a11 fell close to the smooth curve. Part of the random scatter in the points is due to the random weighting of a particular zone by the starting and ending points of the orbits.

Figures $2-7$ and 2-8 show that an ignited central cell should have a plasma radius that is larger than typical alpha orbits in the beta-reduced magnetic field. As discussed above, the increased loss of alpha power resuling from a small plasma radius can be made up by increasing the length of the central ce1l, by increasing the magnetic field strength, or by decreasing beta so that the ignition criterion ia still satisfied. 


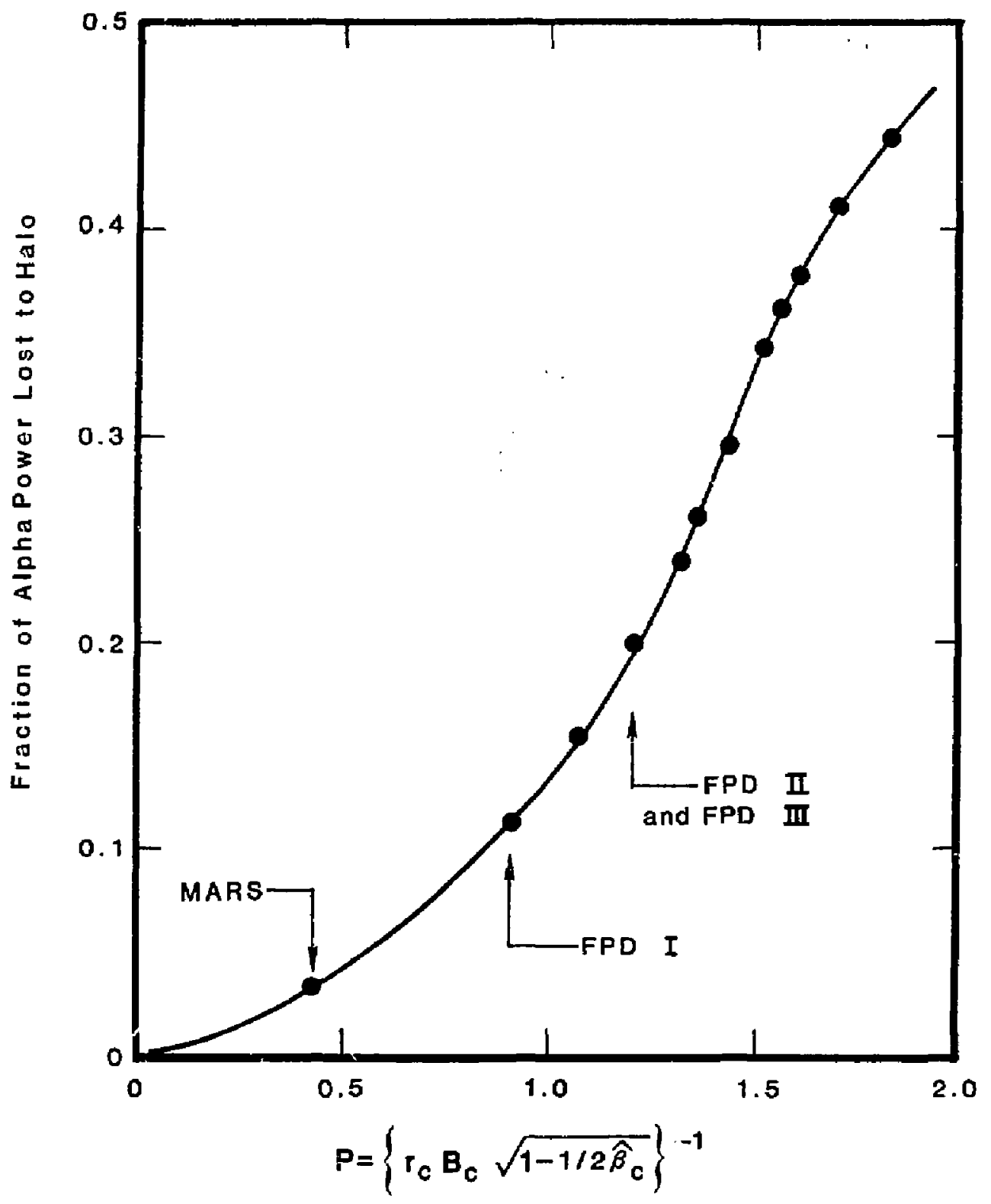

Fig. 2-8. Fraction of the central-cell fusion alpha power deposited in the halo, expressed in terme of a system parameter $P$, where $P$ is a function of the central-cell plasma radius $r_{c}$, the central-cell $B$-field $B_{C_{B}}$ and the central-cell peak beta $B_{C}$. The operating points for MARS, FPD-I, ${ }^{2}$ FPD-II, ${ }^{2}$ and FPD-III are shown. 


\section{REFERENCES}

1. C. D. Henning et al., Fusion Power Demonstration: Baseline Report, Lawrence Livermore National Laboratory, Livermore, CA, UCID-19975 (1984).

2. Eusion Power Demonstrations $I$ and II, J. N. Doggett, Ed.: Lawrence iivermore National Laboratory, Livermore, CA, UCID-19975-1 (1985).

3. T. C. Simonen et a1., 2XIIB Plasma Confinement Experiments, in Proc. of the 7th. IAEA Conf. Plasma Phys. and Cont. Nucl. Fusion Res., Nucl. Fusion, Supplement, Vol. II, 389 (1979).

4. R. W. Moir et a1., Standard Mirror Fusion Reactor Design Study, Lawrence Livermore Nationa1 Laboratory, Livermore, CA, JCID-17644 (197B).

5. Summary of TMX-U ResultB: 1984, T. C. Simonen, Ed., Lawrence Livermore National Laboratory, Livermore, CA, UCtD-20274, Vol. I and II (1984).

6. B. G. Logan et a1., MARS Mirror Advanced Reactor Study, Fina1 Report, Commercial Fusion Electric Plent, Lawrence Livexmore National Laboratoxy, Livermore, CA, UCRL-53480, Volo. IA and 1B (1984).

7. Y. V. Gott, M. S. Ioffe, and V. G. Telkovaky, Some New Results on Confinement in Magnetic Traps, in Proc. of the IAEA Conf. Plasma Phys. and Cont. Nucl. Fusion Res., Nucl. Fusion, Supplement, Vol. III, 1045 (1962).

8. A. H. Futch et a1., Stability of a Megnetica1ly Confined 20-keV Steady-State Plasme Research, in Proc. of the IAEA Conf. on Plasma Phys, and Conț. Nucl. Fusion Res., Nucl. Fügion, Supplement, Vol. II, 3 (1965).

9. D. E. Baldwin, Advantages of Higher-Order Multipole Tandem Mirror Plugs, Lawrence Livermore National Laboratory, Livermore, $\mathrm{CA}_{A}$, unpublighed memorandum (1978).

10. E. B. Hooper, Jr., Octopole Anchor for Tandem Mirtors, Lawrence Liveriuc:e National Laboratory, Livermore, CA, UCID-20050 (1984).

11. R. S. Devoto et al., A Small Octopole-Stabilized Tandem Mirror Reactor, Lawrence Livermore National Laboratory, Livermore, CA, UCID-20157 (1984) (to be published in Nucl. Fusion).

12. L. J. Perkins et al., Plesmg Engineering for MINIMARS: A Sma11 Commercial Tandem Mirror Resctor With Octopole End Plugs, Lawrence Liveraore National Laboratory, Livermore, CA, UCRL-92023 (1985) (to be published in Fusion Technology). 
13. MINIMARS: Interim Design Report, J. N. Doggett; Ed., Lawrence Livermore National Laboretory, Livermore, CA, (to be published 1985).

14. R. S. Devoto, Lawrence Livermore National Laboratory, Livermore, CA, private communication (1984).

15. T. B. Kaiser, W. A. Newcomb, and L. D. Pearlstein, Equilibrj Im and Stability of Higher-Order Multipole Tandem Mirrors at Low Be a, Lawrence Livermore National Laboratory, Livermore, CA (to be publiahed 1985).

16. W. L. Barr et A1., "Energy Loss of Alpha Particles to the Halo Plasma in Tandem Mirrors," Bull. Amer. Phys. Soc. 29 Na. 8, 1226 (1984). 
Section 3

Systems Design 
GENERAL DESCRIPTION

The third version of the Fusion Power Demonstration (FPD-III) device is designed to produce $140 \mathrm{WW}$ of fusion power. As chown in Fig. 3-1 and 3-2, the device is $67.5-\mathrm{m}$ long with a diameter of $8.2 \mathrm{~m}$ and a centerline height of $9 \mathrm{~m}$. The device is assembled from six moduler central-cell sections, a fueling/diagnostic sector, and an end cell with a direct converter region on each end.

Each central-cell module (approximately $5.5 \mathrm{~m}$ in length and $7 \mathrm{~m}$ in diameter) contains the blanket, shield, solenoid coil, and vacuum tank required to make each module a "stand-alope" unit. A typical central-cell unit is shown in Fig. 3-3.

A11 FPD-III modules, with the exception of the end modules (those closest to the end cells) are interchangeable. The proximity of the high-field (24-T) choke coil to the solenoids in these modules jictates that we provide a Bpecial structure to react the high, magnetically-induced axial loads thet occur between the windings of the solenoid and the choke coils. We envision a special case for the solenoid as well as permanent otructure linking the two coils. The length of the central cells and, this, the required number of cells were chosen to limit both the ragnetohydrodynamic (MHD) effects within the blanket and the veight of the aasembly for handling. With the fluids in the shield and the blanket removed, the weight of a module is estimated at $250 \mathrm{Mg}$ (275 tons).

Each module contains a cylindrical, Iithium-lead blanket in the area adjacent to the plasma. The recirculating lithium lead enters each module from the interconnecting pipes through a header located in the top of the vacutm vessel at the axial centerline, and exita to the header at the bottom of the vessel. Surrounding the blanket is a shield filled with high-density, stainless-steel balls that protect the outboard superconducting coils from nuclear heating and fluence. The shield is oupporced by a spaceframe tying the shield to the exterior vacuum wall and the struts that support the module above the ground, A solenoid coil, aized to produce the required $2.5-\mathrm{T}$ field 


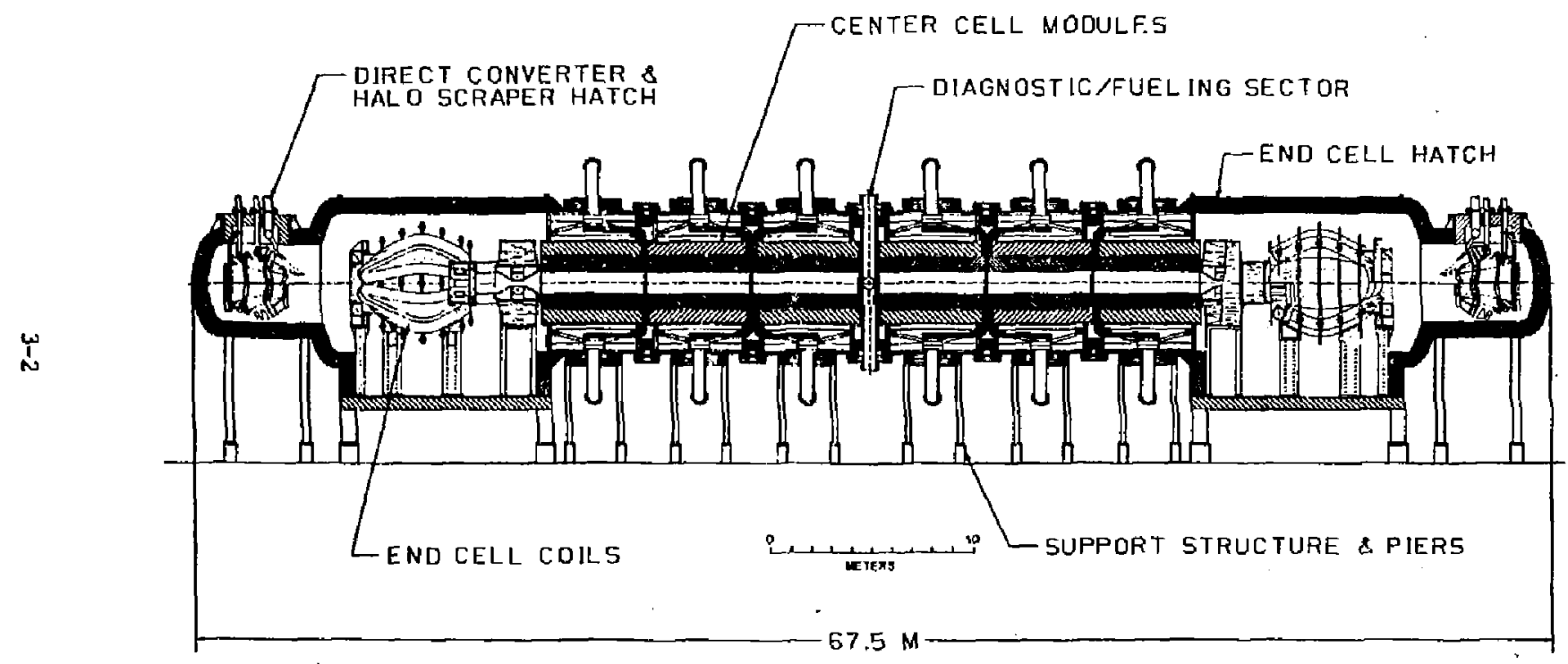

F1g. 3-1. FPD-III elevation view. 


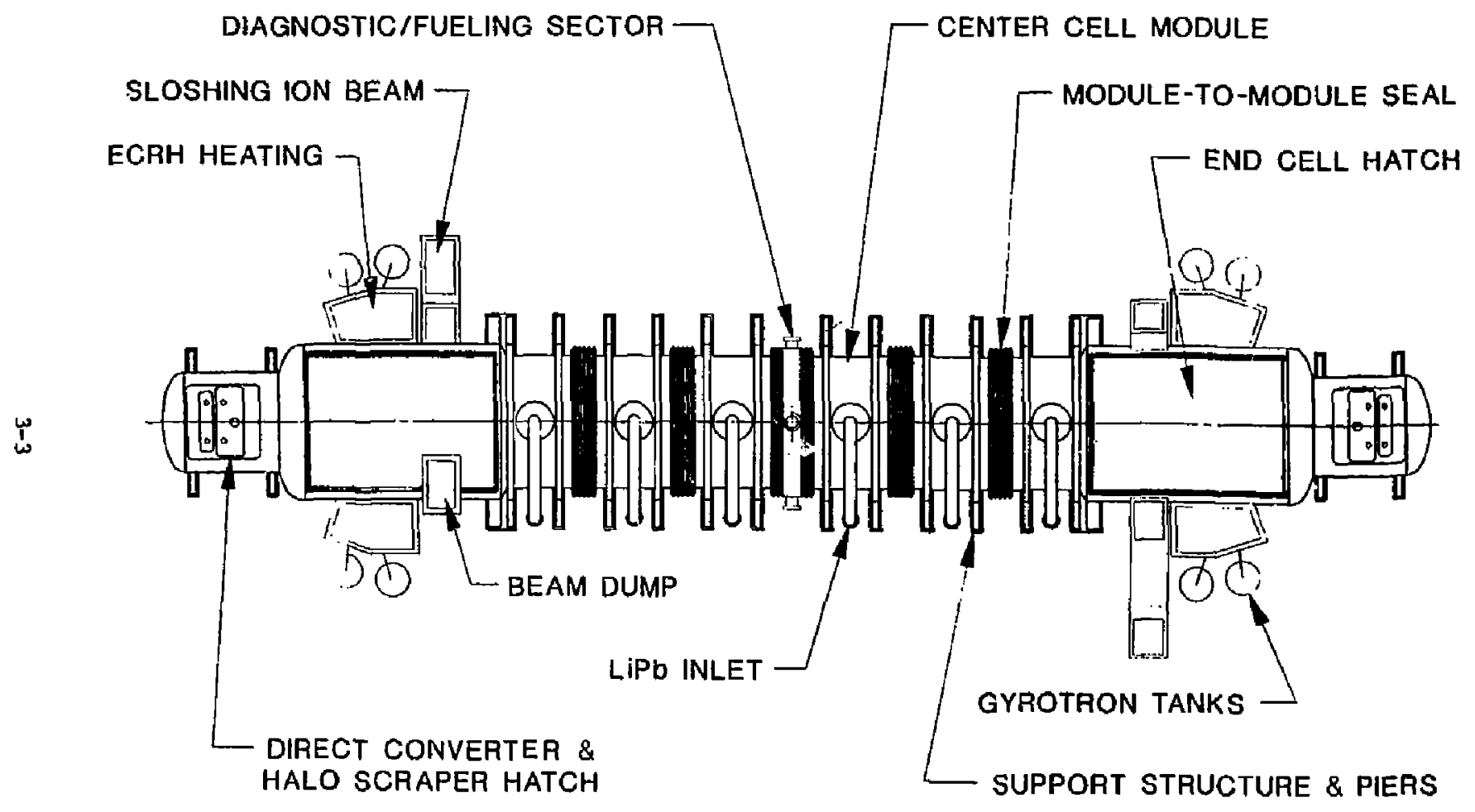

Fig. 3-2. FPD-III plan view. 


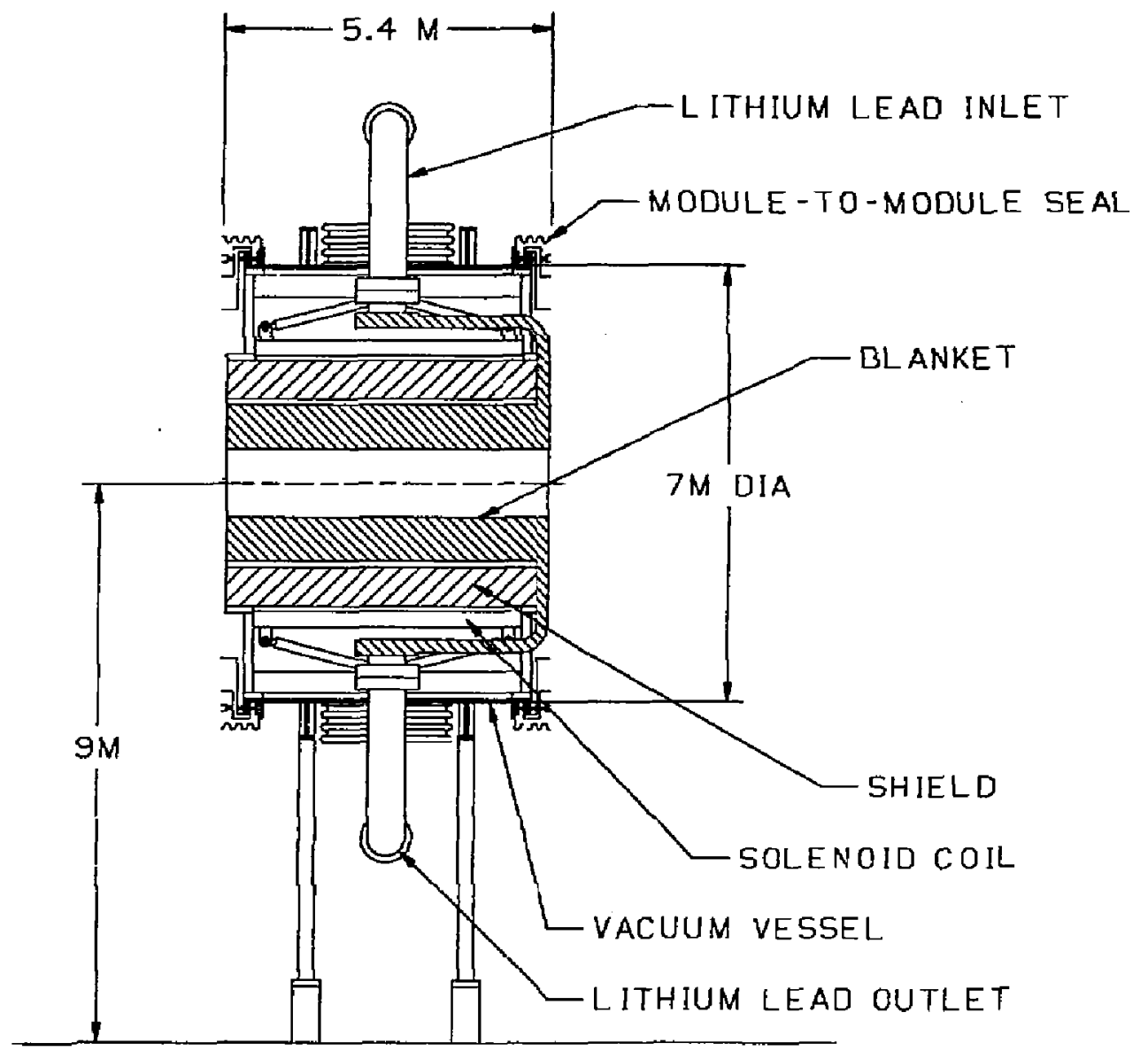

Fig. 3-3. Centra1 celI module--elevation view. 
on axis, surrounds the shield. Because this winding rast be reduced in axial length to allow the support structure and piping to reach the shield and blanket, each end is outfitted with extra windings to reduce the field ripple in the gaps between adjacent modules. A single-wall, stainless-gteel veroel, reinforced by two circumferential bands, surrounds each module; when the scainless-steel vessel is connected to the other central-cell sectors and the end cells, it forms the vacuun boundary for the device.

Centra1-cell modules are structurally interconnected by a series of tie bolts used to resist the axial load and by a series of bellows used to form the circumferential vacuum aeal. This arrangement allows us to remove the four central modules from the device, independently, for mainterance or repair. The two outer modules are welded to the end-cel1 vacuum tank and can be removed only after removing the adjacent module. A special dector containing four 60-cm ports, giving fueling and/or diagnostic access to the plasma, is used to connect the two center modules. The design of the connection schetue is shown in Fig. 3-4.

The FPD-III device differs from prior tanden mirror reactor configurations in that the end cell is based on an octopole coil concept. In addition to this coil set (consisting of the choke coils, a transition octopole, the large octopole, and an outer-mirror coil), the end cell contains heating provisions using negative-ion neutral beams and electron-cyclotron resonant beating (ECRH), drift pumping, a halo scraper, and a direct converter. End-cell components are contained in a vacuum vessel $8.2 \mathrm{~m}$ in diameter and almost $I B \mathrm{~m}$ in length. The vacuum boundary is extended in wing-like appendages for the ECRH and coil-support systems.

The principal feature of the end cell is the octopole magnet. We considered three distinct manufacturing concepts for this magnet before arriving at the arrangement shown in Fig. 3-5. A continuously wound octcpole magnet provides the required access for the neutral beam, but is very difficult, and therefore expensive, to manufacture and maintain. An octopole assembled from eight individually-wound window frames, while providing ease of manufacture, results in very limited beam-injection access. Machine configurations based on the continuously-wound and eight-window-frame-octopole end cella are shown in Figs. 3-6 and 3-7. 
(a)
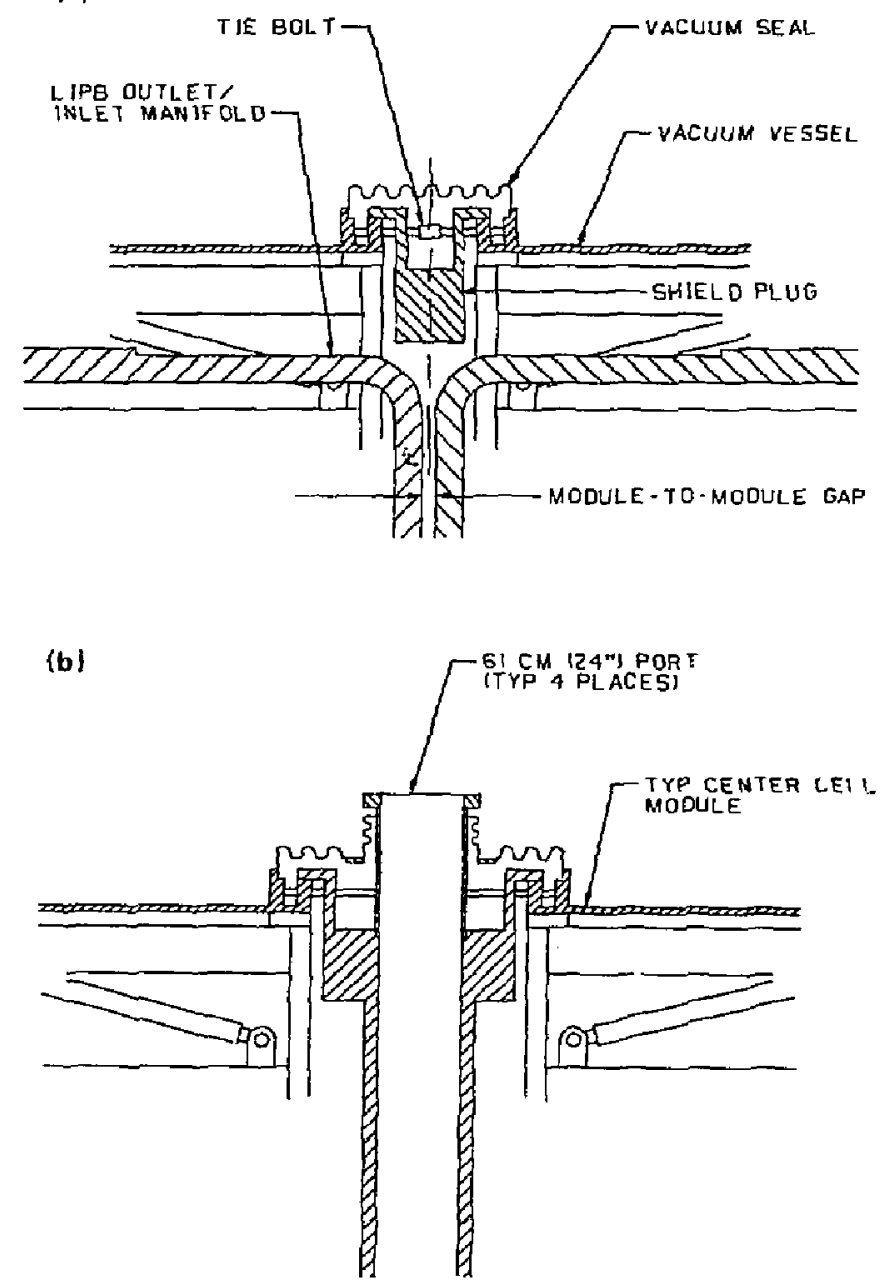

Fig. 3-4. (a) Module-to-module seal and (b) fueling/diagnositis sector. 


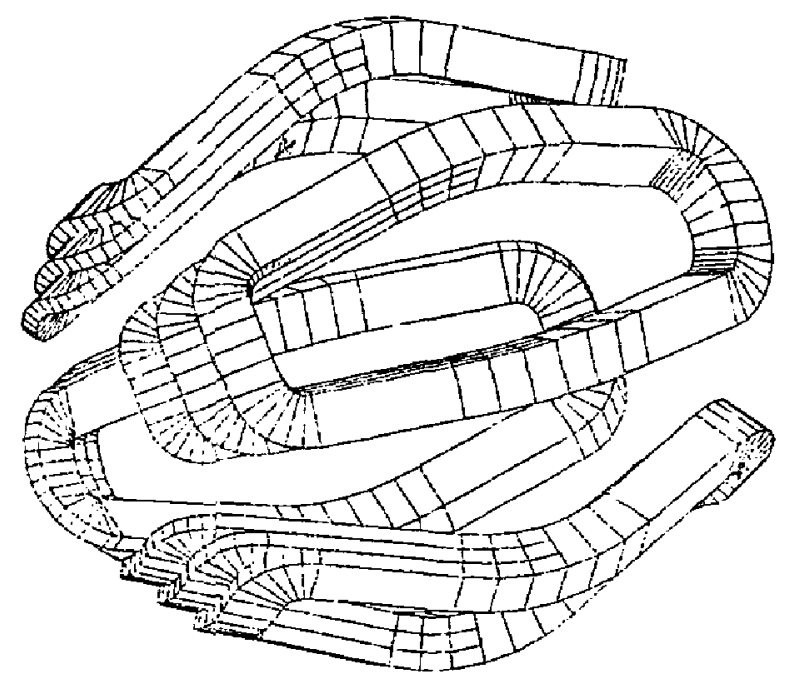

Fig. 3-5. Octopole coil, four-window-frame concept. 


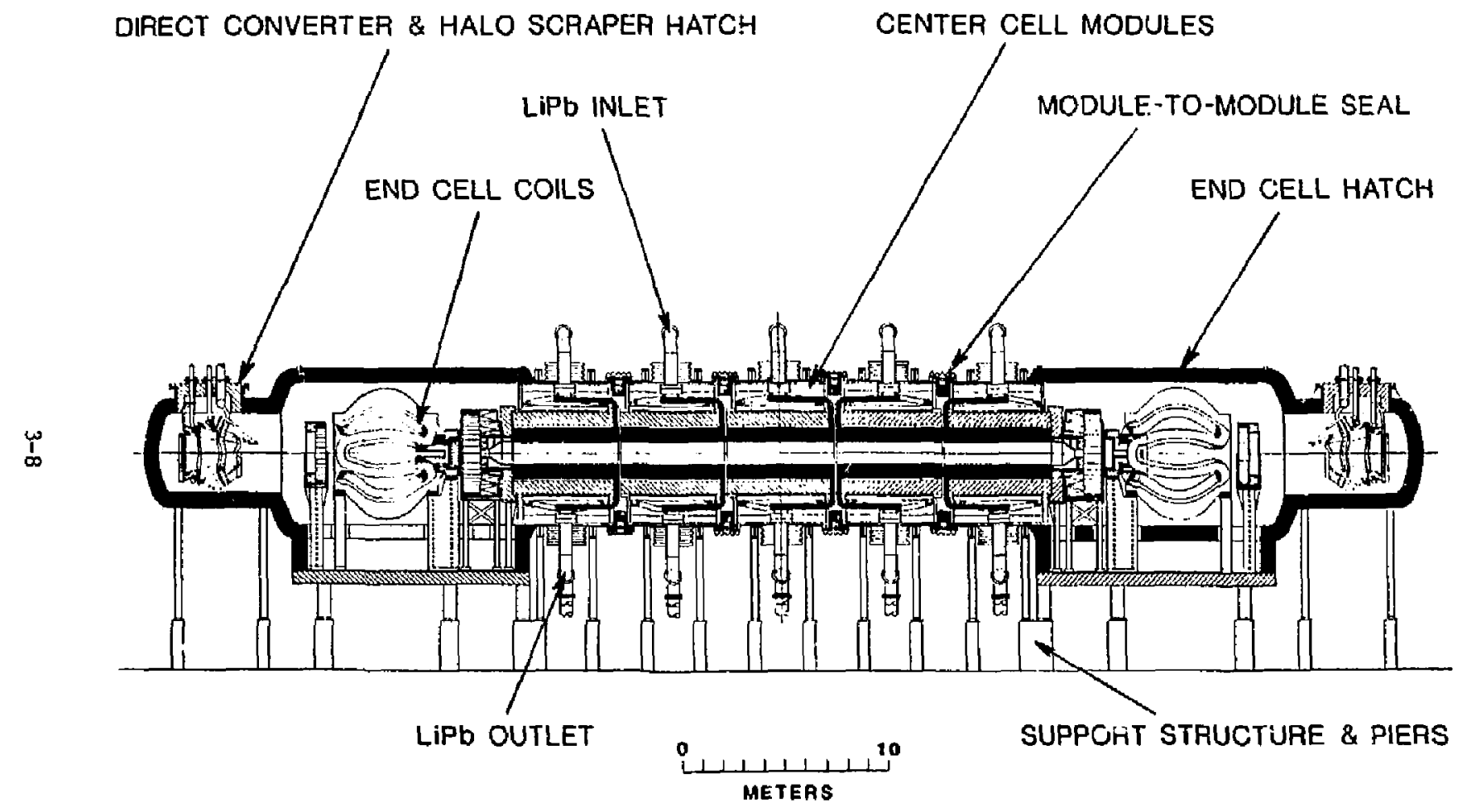

Fig. 3-6. FPD-III with continuously-wound octopole. 


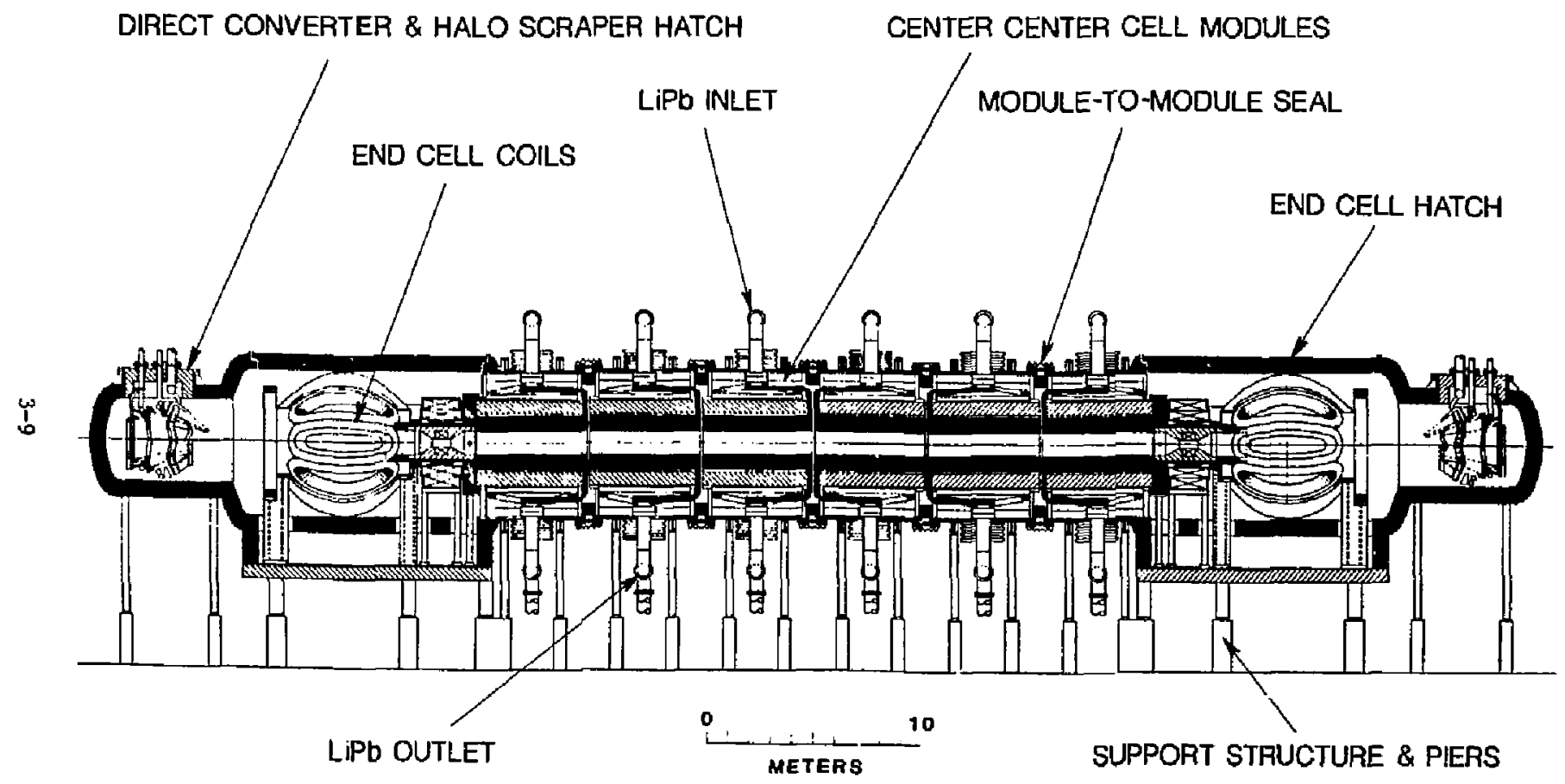

Fig. 3-7. FPD-III with elght-window-frame octopole. 
The assembly of four window frames not only accommodates the manufacturing/maintenance and beam-access advantages of the former schemes,' but also creates the posaibility of improved accessibility to componenta located within the octopole. As discussed in greater detail later, we propose a structural-support scheme featuring demountable circumferential oupport, which would allow the upper window frame(s) to be independently removed from the vacuun vesse1, exposing other components to top access. Further work in positioning of the outer mirror coil $(\mathrm{s})$, developing schemes for axisl load ties between coils, and a check of ocher than normal operational loads is required to establish the feasibility of this scheme.

other magnets in the end-coil set include a $24-T$ choke coil, a smaller "transition" octopole, a correction coil, and an outer mirror coil. All coils, with the exception of a resistive insert coil in the high-field region of the choke, are superconducting. A feature of the four-vindow-frame-octopole concept is that circumferential currents at opposite ends of the legs flow in opposite directions; a correction coil must be included to compensate for these currents. Because this correction coil must be located in close proximity to the octopole, the octopole must be stepped, creating the geometry show in Fig. 3-5. The coil weight is supported by struts tied to the vacuum vessel with a trough extension on the undergide of the vesgel. This extension allows the atruts to be of maximum length, minimizing heat flow to the cold coils. The ECRH is applied at thrae locations in each end ce11. The thermal barrier for point " $\mathrm{b}$ " and the electron mantle are at the same axial location (31 $\mathrm{cm}$ beyond the midplane of the large actopole magnet). The "b" region is on axis, whereas the mantle is centered 90 -cm off axis. The third EGRl system for the potential peak is located at point "a", approximately $1 \mathrm{~m}$ beyond point "b" towards the end of the device. The "a" system requires one 200-kW gyrotron, whereas the "b" and mantle systems each use six 1-MW gyrotrons per end.

The thermal-barrier system employs a quasi-optical launching and transport system contained in the wing-j,ike appendage to the vacuum vessel centered on the horizontal midplane. Beam launcherg are arrayed axially so that the ECRH beang pass between the windings of the coils. The launchers for the point "a" and mantle systems are placed inside the vacuum vessel. A 
waveguide interface penetrates the vesuel, carrying the power from the gyrotrons to the launcher. The total prime power required for the three systems is approximately $45 \mathrm{kw}$.

The 475-kev, negative-ion-based, neutral-beam system is positioned to produce the sloshing-ion distribution in each plug. This was the most difficult system to integrate becauge of the very restricted space available in the required location (the midplane of the omall octopole). In this case the beam must pass through an area already crowded by magnetic windings, structure, neutron shielding, and coil crossovers. The octopole magnets in one end cell are rotated $45 \mathrm{deg}$ about the machine axis relative to those in the other end. Because of the different orientation of the coils in each end cel1, one bermline is entered on the aximuthal midplane, whereas the beamline of the other end of the device enters at an angle of $45 \mathrm{deg}$ below midplane.

Drift pumping coils are located at two axial locations in each end cell. A slotted antenna encircles the plasma to pump the ion speciea trapped in the plasma core in the region of the small octopole. In the outer end of the large ontopole, four aplit-coax sections follow the lobes of the plasma-edge surfaces along the axial extent of the 1-nr-long coaxial cavities.

The end cell employs a double-wall vacuum tank with $60 \mathrm{~cm}$ of biological shielding and water between the wolls. A hatch opans axially frorn the choke coil to the outer mirror coil and has sufficient circumferential width to allow installation/removal of the end-cell magnets. The vacuum-tank diameter is reduced in the region of the halo scraper/direct converter. The halo scraper/direct converter is ingtalled through a port on the upper side of the vessel.

CENTRAL CELL MAGNETS

The magnet system of FPD-III shown in Fig. 3-8 consists of central cell, choke, and end-plug coils. The centraI-cell magnet aygtem has aix (CC1 to cc3) solenoid modules. Each individual module has a correction coil ar each end for reducing the ripple in the plasma region to an acceptable level. The magnetic-field-ripple profile along the plasma axis is shown in Fig. 3-9--this field profile meets the system requirements. 

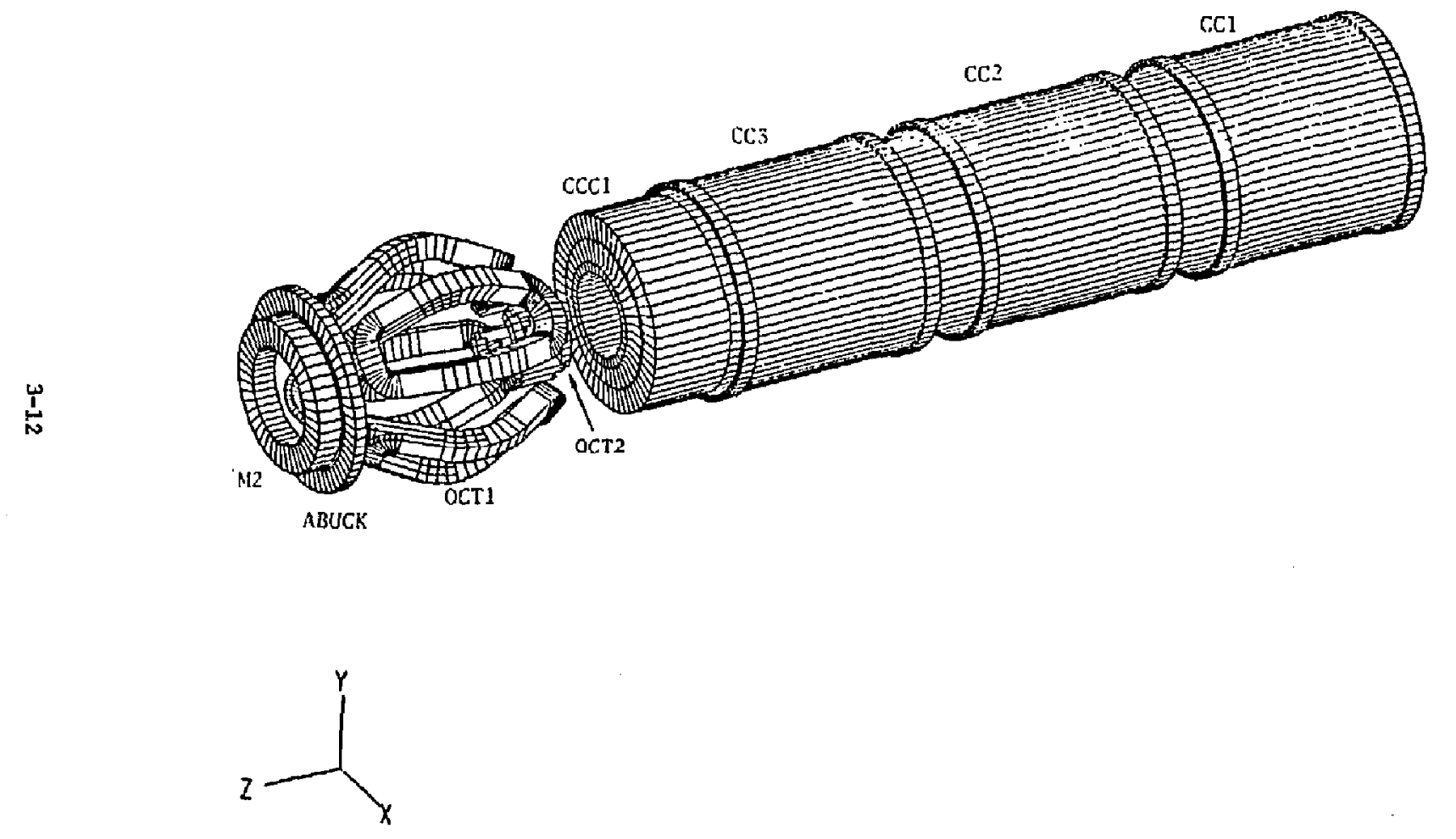

Ffg. 3-8. FPD-III magnet system configuration with window-frame coils for ocT1. 

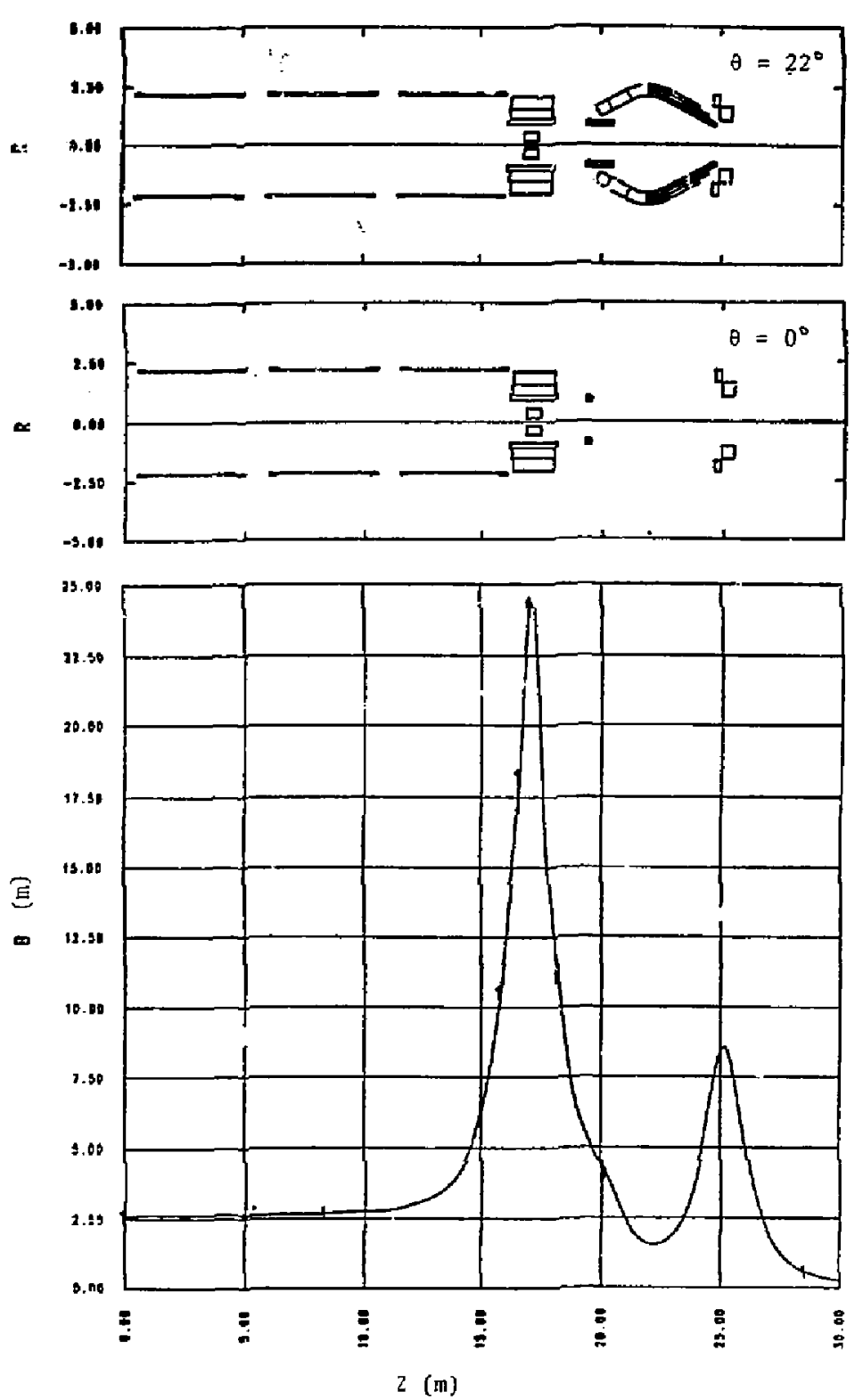

Fig. 3-9. Axial field profile and cross section of coils at $\theta=0^{\circ}$ and $22.5^{\circ}$. 


\section{System Function Summary}

The central-cell magnet system confines thr plasma over its entire length. The central-cell length is determined from plasma requireme:ts like particle confinement time (to ensure ignition) and the average beta.

\section{Reguirement Summary}

The FPD-III central cell is $32-\mathrm{m}$ long; the field required on the plasma axis is $2.5 \mathrm{~T}$. The magnetic-field ripple is limited to les $\mathrm{s}$ than $1 \%$ for achieving the required central cell beta $\beta_{c c}$. The length of the centra1-cell modules must atisfy the physics and engineering constraints. Axial gaps must be provided between adjacent central-cell modules to accommodate coolant feed lines for the nuclear shielding and blanket systems located inside the solenoid modules.

The magnet support structure must be adequate to withstand loads such as magnetic loads, dead weight, $1-g$ seismic load externally and vertically, and operating pressure differentials.

The FPD-III devire is required to operate for ten years at $10 \%$ duty factor. During this period, the magnets are designed to withstand 120 cooldown/warmup cycles.

\section{Magnet Configuration and Design}

The configuration of the central-cell magnets is shown in Figs, 3-8 and 3-9 and relevant design paramciers are given in Table 3-1. Each endcompensated module is 4.5-ru long with 1-m axial gap between the modules. The solenoid modulea are designed to accomplish the desired winding current density of $6000 \mathrm{~A} / \mathrm{cm}^{2}$ at $3.5 \mathrm{~T}$. The winding design is based on a $\mathrm{Nb}_{3} \mathrm{sn}$ cablein-conduic conductor and cooled with forced-flow supercritical the with inlet and outlet temperatures of $4.2 \mathrm{~K}$ and $5.7 \mathrm{~K}$, respectively. The solenoid modules ate layer wound. The main solenoid winding is a single layer of forced-cooled conductor. Two additional layers (about $0.3-m$ axial length) are provided at each end of the main solenoid to provide a ripple correction 
Table 3-1. Central-cel1 magnet-design parameters.

\begin{tabular}{ll}
\hline \multicolumn{1}{c}{ Parameter } & Value \\
\hline & \\
Centra1-cel1 magnet dimensions & 2.15 \\
Mean magnet radius (m) & 32 \\
Axial length (m) & \\
Module design parameters & 4.5 \\
Module length (m) & 0.09 \\
Radial build (m) & 0.03 \\
Axial length of each compensating layer (m) & 10.2 \\
Ampere turns/module (MA turns) & 6000 \\
Winding-current density (A/ $\mathrm{cm}^{2}$ ) & 2.5 \\
Field on axis (T) & 3.5 \\
Peak field at the windirg (T) & 1 \\
Peak nuclear heatiog rate (m/ $/ \mathrm{cm}^{3}$ ) & 60.0 \\
Operating current (kA) & \\
\hline
\end{tabular}


function. The conductor conduit thickness is $6.6 \mathrm{~mm}$, which is three times thicker than the thickness of the Westinghouse-LCP conductor. Although fabricating a 6.6-mm wall conduit is impractical, we may be able to build up the degired wall thickness from 3 to 4 concentric layers. Alternatively, the Westinghouse-LCP conductor can be used in "as is" form if a stainless-steel stxip for taking hoop loads is cowound with the conductor. The average heat load in the winding is $0.12 \mathrm{mw} / \mathrm{cm}^{3}$. This heat load can be removed by LHe flow rate of $5 \mathrm{~g} / \mathrm{s}$ through a 10-turn cooled-path length. The coils can be safely discharged at $800 \mathrm{~V}$ (peak) without exceeding a hot-spot temperature of $280 \mathrm{~K}$.

\section{Conclusion}

The central-cell coils can be designed and fabricated using a modified Westinghouse-LCP conductor to achieve the desired winding-current density of $6000 \mathrm{~A} / \mathrm{cm}^{2}$.

CENTRAL CELL SHIELDING

The shielding for the superconducting solenoids of the central cell is provided by a 55-cm thick, water-cooled steel shield. The drsign of the shield is based on the FPD-I and FPD-II steel-ball concept. ${ }^{2}$ We selected this concept because of its adequate performance and econony of manufacture. In this design, a compartmented, structural-steel case is filled as densely as possible with steel balld. The remaining volume is filled with water, which is slowly circulated for cooling. The shield attenuates neutron and gamma radiation from the reflector portion of the blanket, and thereby reduces the cryogenic heat load to the solenoid. The shield also reduces to acceptable levels the lifetime radiation damage to the solenoid's thermal and electrical insulation.

There are no penetrations through a central-cell module shield. However, there is a gap between the modules. Conceptually, this gap is plugged by a steel ring encircling the gap inside the vacuum vessel as shown in Fig. 3-4. A more detailed neutron-streaming analysis would he required to verify a detail design. 
The shielding required around the fueling modulg has not been adequately adciessed; it would be, however, largely a problem in penetration shielding. The four large penetrations would need to be completely enclosed in a steel shield; once again, a decailed-screaming analysis would be required to verify the design.

FUEL INJECTION SYSTEMS

Two types of fuel injection systems are provided to meet the fueling Iequirements for FPD-III. Fuel gas-injection systems are included for initial loading and startup. Fuel pellet-injection syatems are used to meet the deep-plasma fueling requirements doring steady-state operation.

\section{Fuel Gas Injection}

The fuel gas-injection requirements are given in Table 3-2. Two independent gas injection systems are provided to meet these requirements for initial loading and startup. Figure 3-10 shows the fuel gas supply, injection-control valves, and instrument and control (ISC). The mnemonics used in this figure are identified in Table 3-3. Either gas injection system can meet al1 the requirements for low-density-deuterium plasma-physics experiments and for initial loading and startup to high-density deuterium-tritium (DT) plasma operation. The gas-injection systems can supply deuterium gas, but not tritium gas. Therefore, conventional gas-injection systems developed for other fusion machines may be procured without having to upgrade the equipment to meet tritiun safety requirements. Both pulsed and analog modes of operation are provided in FPD-III.

\section{Fuel Pellet Injection}

Previously for FPD-I and FPD-II, ${ }^{2}$ we determined that a first-stage preumatic injector, followed by a fractical gecond-stage railgun pel let accelerator, could not provide sufficient entry velocity to fuel the center of the plagma. For FPD-III, our preliminary calculations show that we may be 
Table 3-2. Fuel gas-injection design-requirements data.

Number of gas-injection systems

2

Number of centra1-ce11-injection nozales located near the pellet-injection tubes

2

Maximum deuterium gas flow through a

central-cel1 nozzle $(g / h)$

Number of end cell injection nozzles

teft and octopole cell

Right and octopole cell

Maximum deuterium gas flow through an end cell nozzle $(g / h)$

60

Gas composition ( $\%$ D2)

Operating control modes

Mode 1

Pulsed

Hode 2

Modulated 


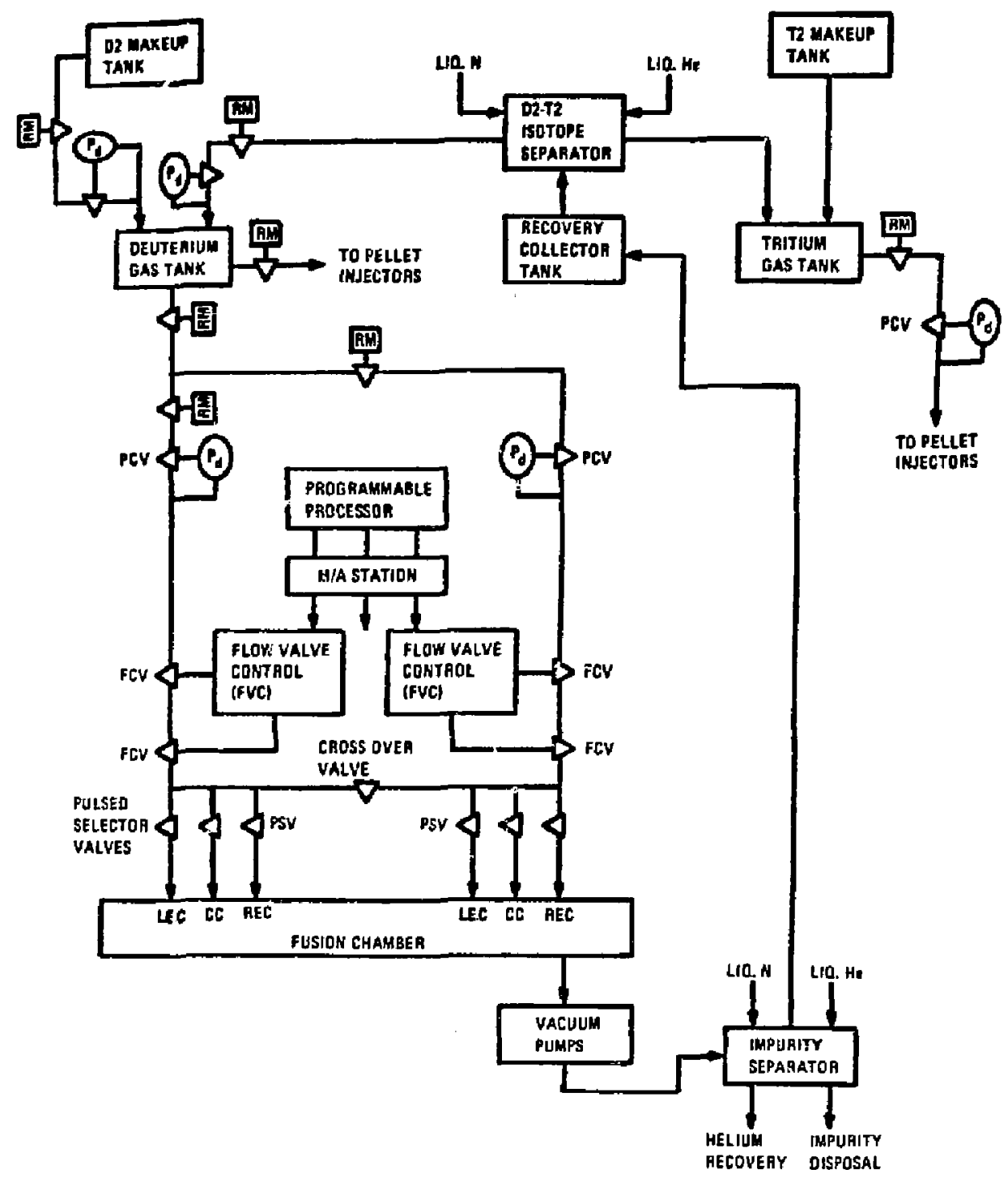

Fig. 3-10. Flow diagram of the fuel gas system. 
Table 3-3. Mnemonic definitions used in Fig. 3-10.

$\begin{array}{ll}\text { D2 } & \text { Deuterium } \\ \text { T2 } & \text { Tritium } \\ \text { N } & \text { Nitrogen } \\ \text { He } & \text { Helium } \\ \text { Pd } & \text { Pressure-drop control } \\ \text { RM } & \text { Remote manually controlied valve } \\ \text { PCV } & \text { Pressure-control valve } \\ \text { M/A } & \text { Manual/automatic } \\ \text { FCV } & \text { Flow-control valve } \\ \text { PSV } & \text { Pulsed-selector valve } \\ \text { LEC } & \text { Left end cell } \\ \text { CC } & \text { Central cell } \\ \text { REC } & \text { Right end cell }\end{array}$


able co use laser pellet driver instead of an electromagnetic railgut to create an ionized fueling plume that has enough pressure to overcome the magnetic-field pressure and reach the center of the plagma. Using the pellet-plagma-plume model for FPD-III developed by Grant logan of lawrence Livermore National Laboratory (LINL) and the most recent FPD-III physics data, we calculated the requirenents data given in Table 3-4 for two fueling scenarios. The smallex 1 -mm-dism fuel pellet requires a higher pellet repetition rate and has less plasma penetretion capability. The larger pellet size is based on the desire to limit the pellet mas to $10 \%$ of the plasma mass. More laser energy is required per pellet for the latter case, but the repetition rate is greatly reduced.

We discussed the preliminary requirements given in Table 3-4 with laeer suppliers and users, who prefer optical-range lasers because more robugt quartz optica $c$ an be used at the vacuum boundary instead of the crustalline salt optics needed for infrared $\mathrm{CO}_{2}$ 1asers. Optical-frequency-range lasers can meet the repetition rate requirements, but fall far short of providing the energy needed for even the l-mn pellet used in reasonably sized laser systems. Infrared lasers can readily meet the energy-per-pellet requirements of FPD-III, but do not meet the pellet rates needed for even the largest pellet permitted. Both the laser suppliera and users at Los Alamos National Laboratory believe that the $\mathrm{CO}_{2}$ laser has the best potertial for meeting our requirementa. The system proposed for FPD-III is based on the use of four $\mathrm{CO}_{2}$ laser beamlines. Four beamlines are used because of the energy deraity limitations of infrared lenses and windows.

Because of laser cost, only one laser syatem is proposed for the two pneumatic pellet injectors located in the FPD-III reactor vault (Fig. 3-11). The pneumatic guns are oriented about $5 \mathrm{deg}$ relative to the common laser-bean tube. Both the laser tube and the pellet-injector tubes lie in the horizontal midplane of the reactor. They interface with a common module that inserts into a 24-in. tube that is located in a special fueling- and diagnostic-belt sector about $1-m$ wide. Three other diagnostic-insert modules are located in this belt sector, one of them is oriented vertically and can be removed from above with an overhead crane. 
Table 3-4. Pellet-injector design-requirements data.

\begin{tabular}{|c|c|c|}
\hline Data description & Scenario 1 & Scenario 2 \\
\hline Number of pellet injectors & 2 & 2 \\
\hline Fuel pellet diameter $(d \neq h)$ & 1.0 & 1.9 \\
\hline Pellet fueling rate $\left(\theta^{-1}\right)$ & 32 & 5 \\
\hline Pellet velocity $(\mathrm{m} / \mathrm{s})$ & $\geq 1000$ & $\geq 1000$ \\
\hline Absorted laser energy per pellet $(\mathrm{kJ})$ & 1.0 & 6.4 \\
\hline Energy per laser beamlipe $(k J)$ & 0.25 & 1.6 \\
\hline Lager puloe width (ns) & 28 & 52 \\
\hline Central-cell plasma radius $(\mathrm{cm})$ & 45 & 45 \\
\hline Pellet plume depth into plasma $(\mathrm{cm})$ & 35 & 65 \\
\hline $\begin{array}{l}\text { Approximate stored energy required } \\
\text { per pellet }(\mathrm{kJ})\end{array}$ & Approximate stored energy required & 400 \\
\hline \multicolumn{3}{|l|}{ Fue1 supply rate } \\
\hline Deuterium $(g / h)$ & 12 & 12 \\
\hline Tritium $(g / h)$ & 18 & 28 \\
\hline Vacuum load (1iters/minute) & 1300 & 1000 \\
\hline Nitrogen supply $(g / h)$ & 200 & 200 \\
\hline Helium supply $(g / h)$ & 100 & 100 \\
\hline
\end{tabular}




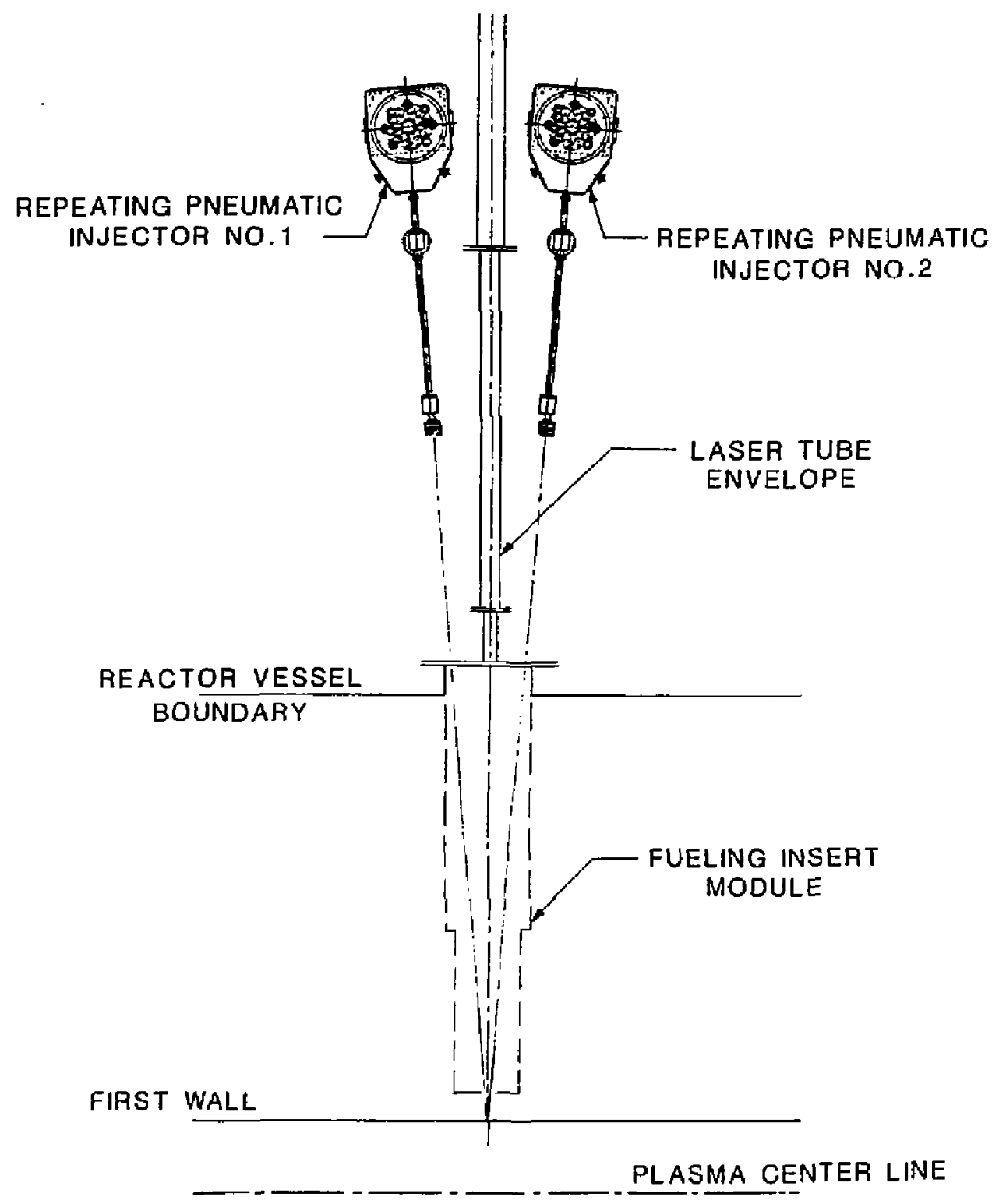

Fig. 3-11. Plan view sketch of repeating pneumatic injectors and laser-beamtube envelopes. 
The laser energy is supplied to FPD-III with four infrared laser bean1 ines, each having four atages (Fig. 3-12). The beamlines are approximately 4-ft wide $\times$ 20-ft long $x$ 6-ft high; they will probably be operated on an unstable lasing mode using converging mirrors to eliminate the need for zinc-selenide converging lenses. Each beamline is connected to the coppermirrot coupling assembly through transition sectors containing alignment bellows and infrared windows lacated on the beamline side of the bialogical shield. Each beamline is mounted on casters so that each one can be aligned with respect to the copper-mirror coupler.

The copper-mirror coupler and beamlines are located about $30 \mathrm{~m}$ from the FPD-III reactor centerline so that large diameter infrared windows can be used to enhance the 1 ifetime of the laser system, and yet require only a relatively small converging tube penetration through the reactor shield: 3-in. diam at the reactor vessel entry to about $3 / 8$-in. dian at the shield-iube exit to the plasma. (The fuel pellet tubing through the shield module is only $1 / 8 \mathrm{in}$. and is supported on a rigid structure within the module.)

Figure 3-13 shows that the mirror coupler contains two 90-deg diledral-: angle mirrors located at different elevations to prevent obstructing any of the laser bean directed toward the reactor. This arrangenent requires that one of the two horizontal beamlines on each side of the mirxor coupler be located at a higher elevation than the other one. The copper mirrors are diamond turned and honed. Laser-beam-induced damage experiments show that copper mirrore have good laser damage resistance and should have good resistanc $:$ to neutron radiation damage. The main neutron beam passes becween the mirror assemblies into the shielded-neucron end catcher, which may also contain plasma diagnostics to take advantage of the small-diameter collimated beam of fagt neutrons. Any backscatter of neutrons must pass through shield material at the rear of the mirrors. Under these conditions, the mirrors should have long lives without significant loss of reflectivity. A large diameter vauum port is located above the mirrors to remove fuel-gas egress from the reactor and any impurities (gases) released by the laser-beam -nteraction with the mirrors or windows.

The long converging-laser tube requires significant structural support and must be vacuum tight at the joints. Joints outside the reactor vault may 


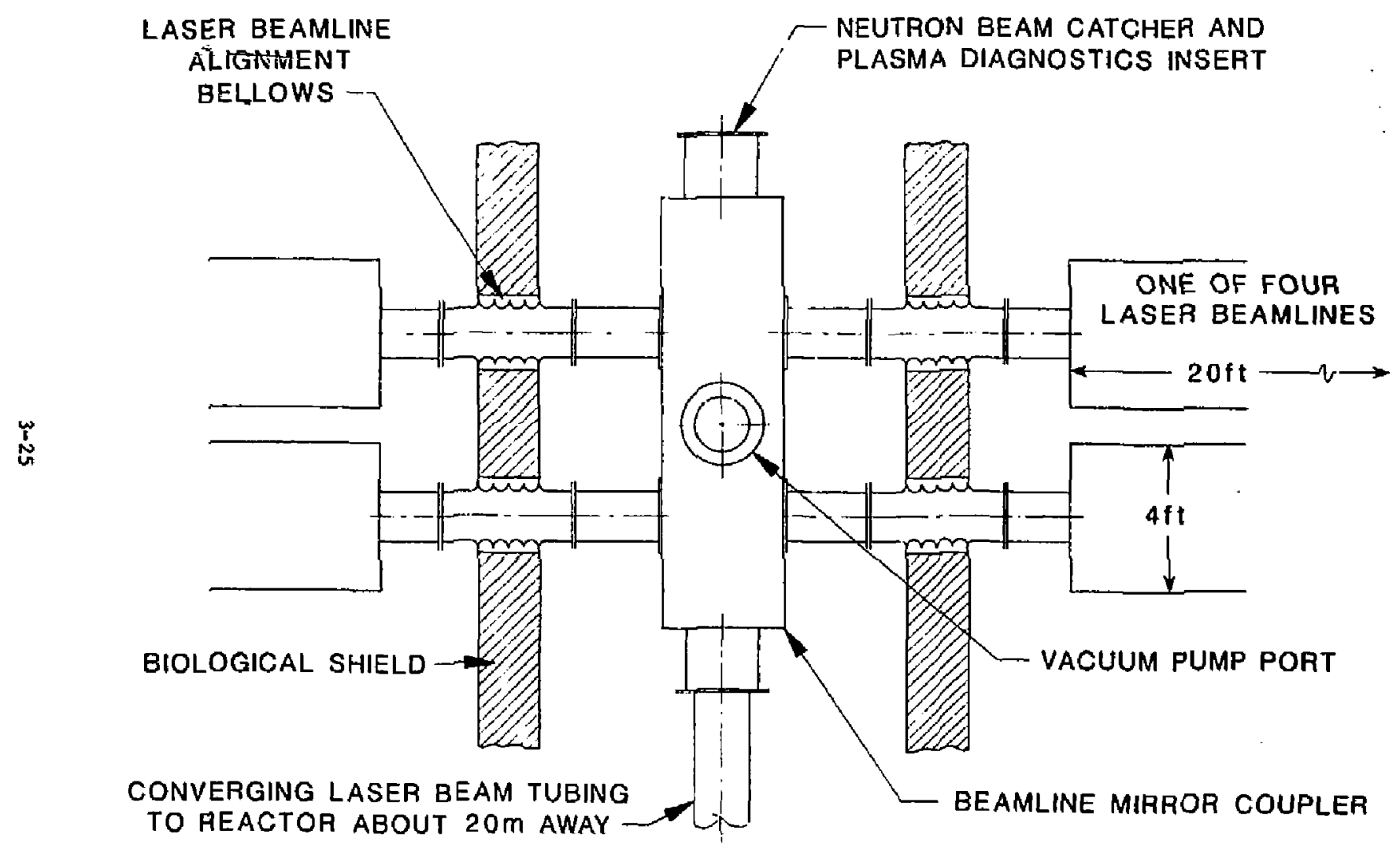

F1g. 3-12. Plan view sketch of lager beamlines and mirror coupler. 


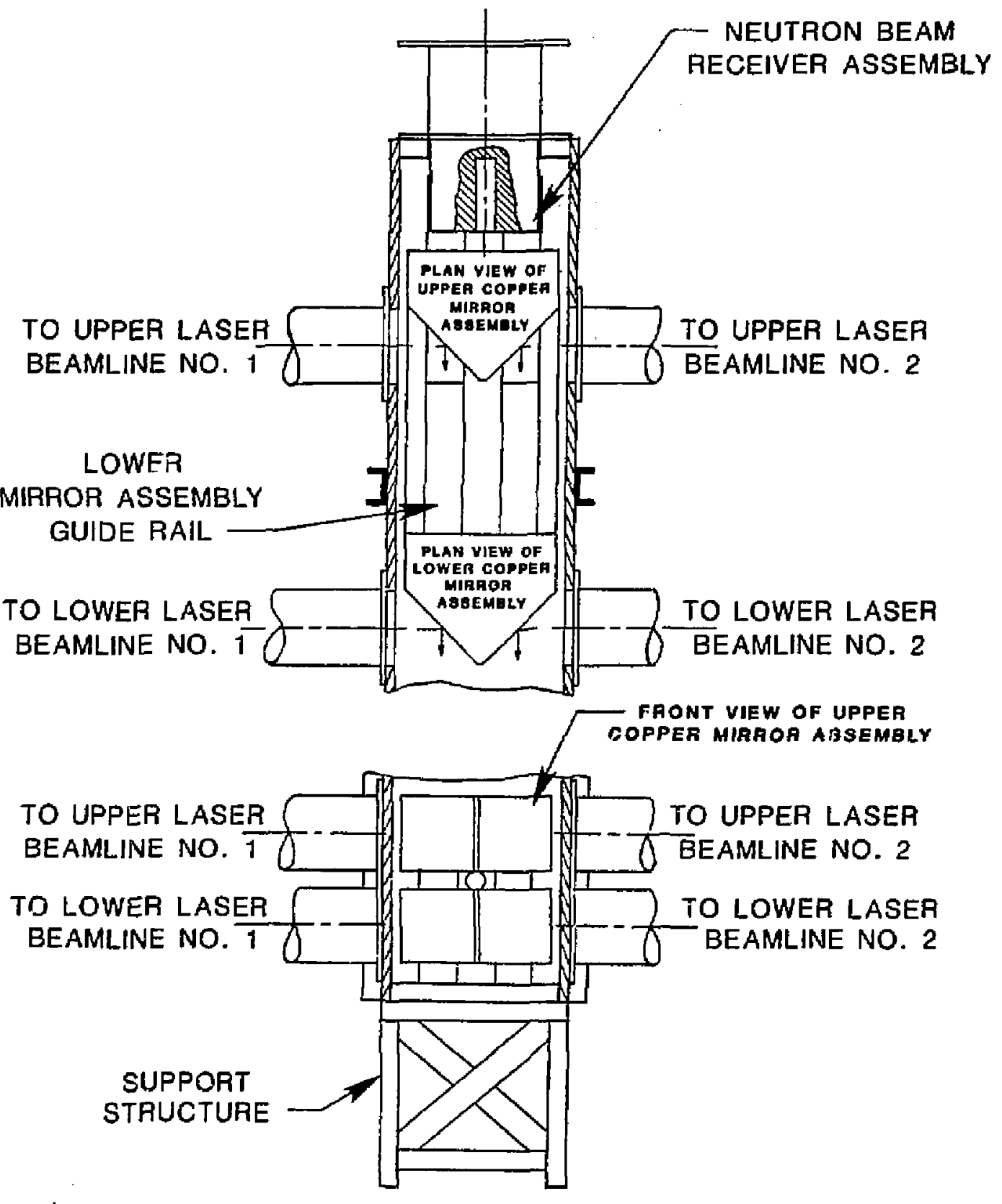

Fig. 3-13. Inside view of the mirror coupler for coubining four lager beamb. 
be welded, but joints inside the vault should be bolted at two locations to permit removal of tubing for remote maintenance operations. Although the penetration through the reactor vault wall is only 10-in, and the neutron beam from the reactor penetration is relarively amall, sone biological-shield wall will probably be necessary around the converging-laser tubing and the mirror-coupling assembly and diagnostics. This wall permits us to control access into the limited induced radiation zone and provides for uninhibited maintenance outside the vault at all times.

\section{MAGNETS}

\section{Hagnet Configuration}

The end-cell magnet configurazion shown in Fig. 3-14 was selected to satisfy the physics requirements for plasma plugging and MHD stability. This configuration consigte of a choke-coil set (CCC1), a small "transition" octopole (OCT2), a large octopole (OCT1), a bucking coil (M1), and a outer-mirror coil (M2). Dimensional data for coil location, coil geometry, current, and field at conductor are given in Table 3-5. The on-axis field, shown in Fig. 3-15, is highlighted by a 24-T requirement in the choke region at $z=17.8 \mathrm{~m}$, falls to a minimum of $1.5 \mathrm{~T}$ at $z=22.2 \mathrm{~m}$, and repeaks to $8.5 \mathrm{~T}$ at $z=25.2$ m to provije plasma confinement.

\section{Magnet Design}

All FPD-III coils, with the exception of the innermost winding of the choke-coil set, are superconducting. Because of the 24-T requirement, a copper winding must be used in the high-field region of the choke-coil set. The two octopole coils a well as the bucking- and outer-mirror coils employ $\mathrm{Nb}_{3} \mathrm{Sn}$ cable-in-conduit conductor. This conductor, shown in Fig. 3-16, is a modified version of the Westinghouge-LCP conductor with its performance optimized to achieve higher winding-current density under large nuclear-heating 2oads. The Tokamak Fusion Core Experiment (TFCX) study shows that this conductor can achieve a current density of approximately $3500 \mathrm{~A} / \mathrm{cm}^{2}$ at $10-\mathrm{T}$ 


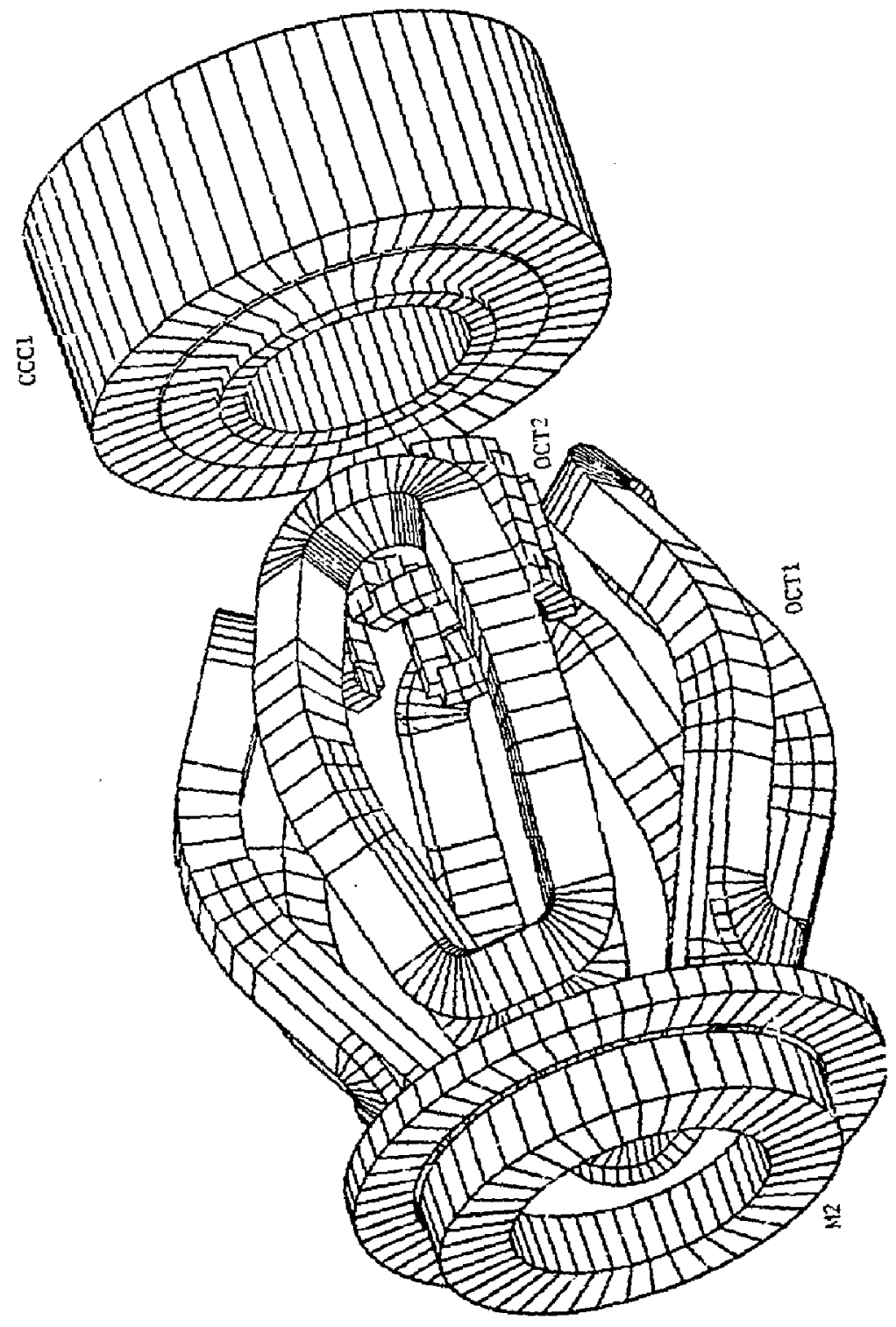

点 
Table 3-5. The FPD-III coil parameters.

\begin{tabular}{|c|c|c|c|c|c|c|c|c|c|}
\hline \multirow[b]{2}{*}{ Coils } & \multirow[b]{2}{*}{$\begin{array}{l}z_{m} \\
(m)\end{array}$} & \multirow[b]{2}{*}{$\begin{array}{l}R_{m} \\
(m)\end{array}$} & \multicolumn{2}{|c|}{ Bundle } & \multirow[b]{2}{*}{$\begin{array}{c}\mathrm{J} \\
\left(\mathrm{A} / \mathrm{cm}^{2}\right)\end{array}$} & \multirow[b]{2}{*}{ MAT } & \multirow[b]{2}{*}{$\begin{array}{l}\mathrm{B}_{\mathrm{m}} \\
(\mathrm{T})\end{array}$} & \multirow[b]{2}{*}{$\begin{array}{c}E \\
(M J)\end{array}$} & \multirow[b]{2}{*}{$\begin{array}{c}I_{0} \\
(\mathrm{kA})\end{array}$} \\
\hline & & & $\begin{array}{l}\mathbf{z} \\
(m)\end{array}$ & $\begin{array}{l}\Delta \mathrm{R} \\
(\mathrm{m})\end{array}$ & & & & & \\
\hline $\begin{array}{l}\text { Mirror } \\
\text { coil, M2 }\end{array}$ & 25.13 & 1.325 & 0.50 & 0.57 & 5500 & 15.67 & 15 & 300 & 10.0 \\
\hline $\begin{array}{l}\text { Bucking } \\
\text { coil, HI }\end{array}$ & 24.72 & 1.885 & 0.25 & 0.47 & 5000 & 5.87 & 9 & 150 & 22.0 \\
\hline $\begin{array}{l}\text { Large } \\
\text { octopole, } \\
\text { OCT1 }\end{array}$ & 21.89 & 2.29 & 0.48 & 0.48 & 2500 & 5.76 & 11.5 & 650 & 20.0 \\
\hline $\begin{array}{l}\text { Smal1 } \\
\text { octopole, } \\
\text { oct2 }\end{array}$ & 22.5 & 0.88 & 0.22 & 0.22 & 4000 & 1.94 & 7.5 & 2 & 25.0 \\
\hline $\begin{array}{l}\text { Choke } \\
\text { coil, CCC }\end{array}$ & $\begin{array}{c}17.08 \\
\vdots . \\
.\end{array}$ & $\begin{array}{l}1.80 \\
1.32 \\
1.00 \\
0.36\end{array}$ & $\begin{array}{l}1.71 \\
1.78 \\
1.97 \\
0.60\end{array}$ & $\begin{array}{l}0.52 \\
0.43 \\
0.20 \\
0.39\end{array}$ & $\begin{array}{l}2476 \\
1803 \\
1675 \\
2480\end{array}$ & $\begin{array}{r}22.02 \\
14.44 \\
6.60 \\
5.80\end{array}$ & $\begin{array}{l}8 \\
12 \\
16 \\
24\end{array}$ & $\begin{array}{r}1130 \\
370 \\
24 \\
3\end{array}$ & \\
\hline \multicolumn{10}{|c|}{$\begin{array}{l}\text { Central } \\
\text { cell coils, } \\
\text { ccl-cc3: }\end{array}$} \\
\hline $\begin{array}{l}\text { Module } \\
\text { Correction }\end{array}$ & Various & $\begin{array}{l}2.157 \\
2.206\end{array}$ & $\begin{array}{l}4.50 \\
0.3 .25\end{array}$ & $\begin{array}{l}0.033 \\
0.066\end{array}$ & $\begin{array}{r}6000 \\
6000\end{array}$ & $\begin{array}{l}8.91 \\
1.29\end{array}$ & $\begin{array}{l}3.5 \\
3.5\end{array}$ & 500 & $\begin{array}{l}60.0 \\
60.0\end{array}$ \\
\hline
\end{tabular}



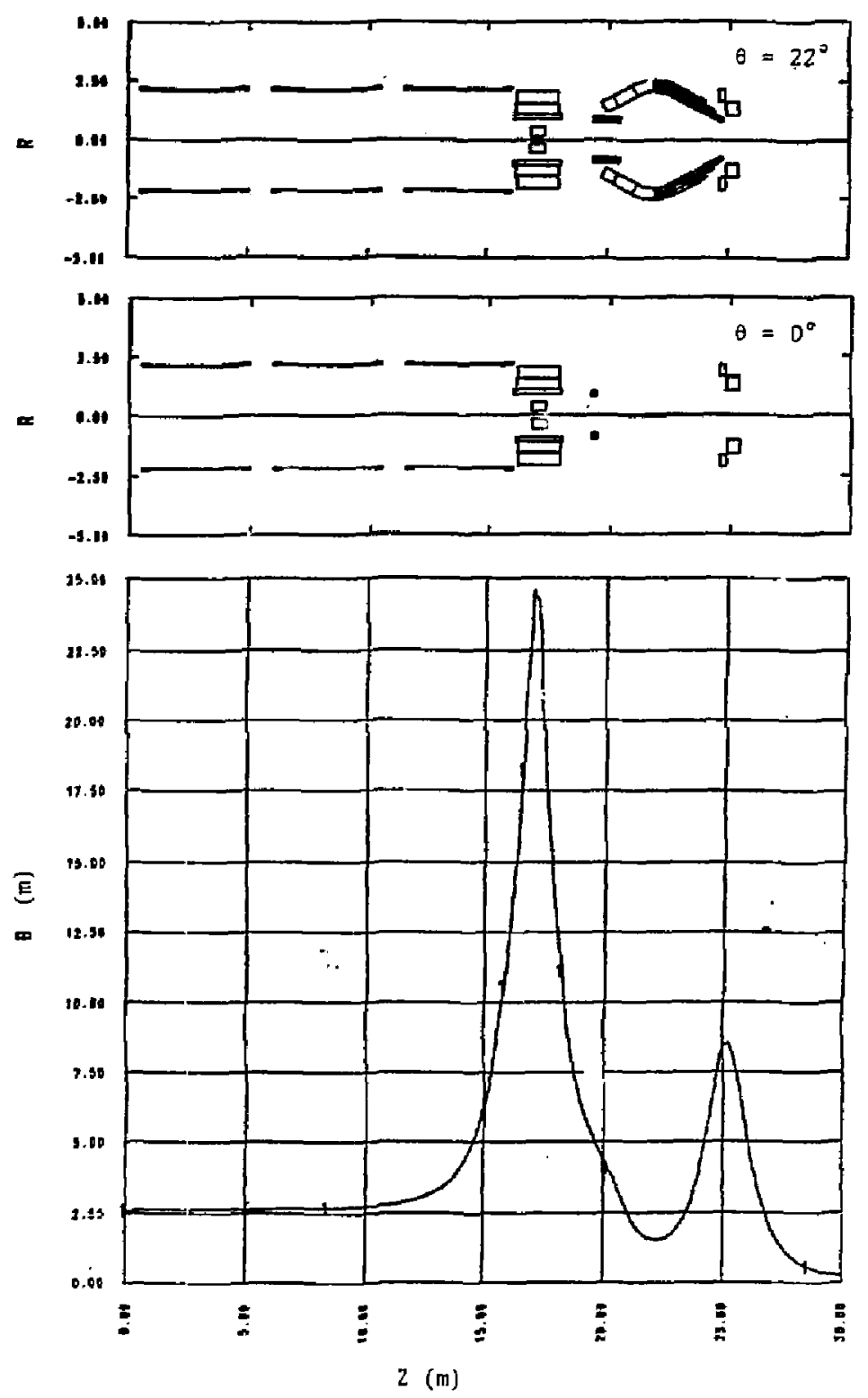

Fig. 3-15. Axial field profile and cross section of coils at $\theta=0^{\circ}$ and $22.5^{\circ}$. 


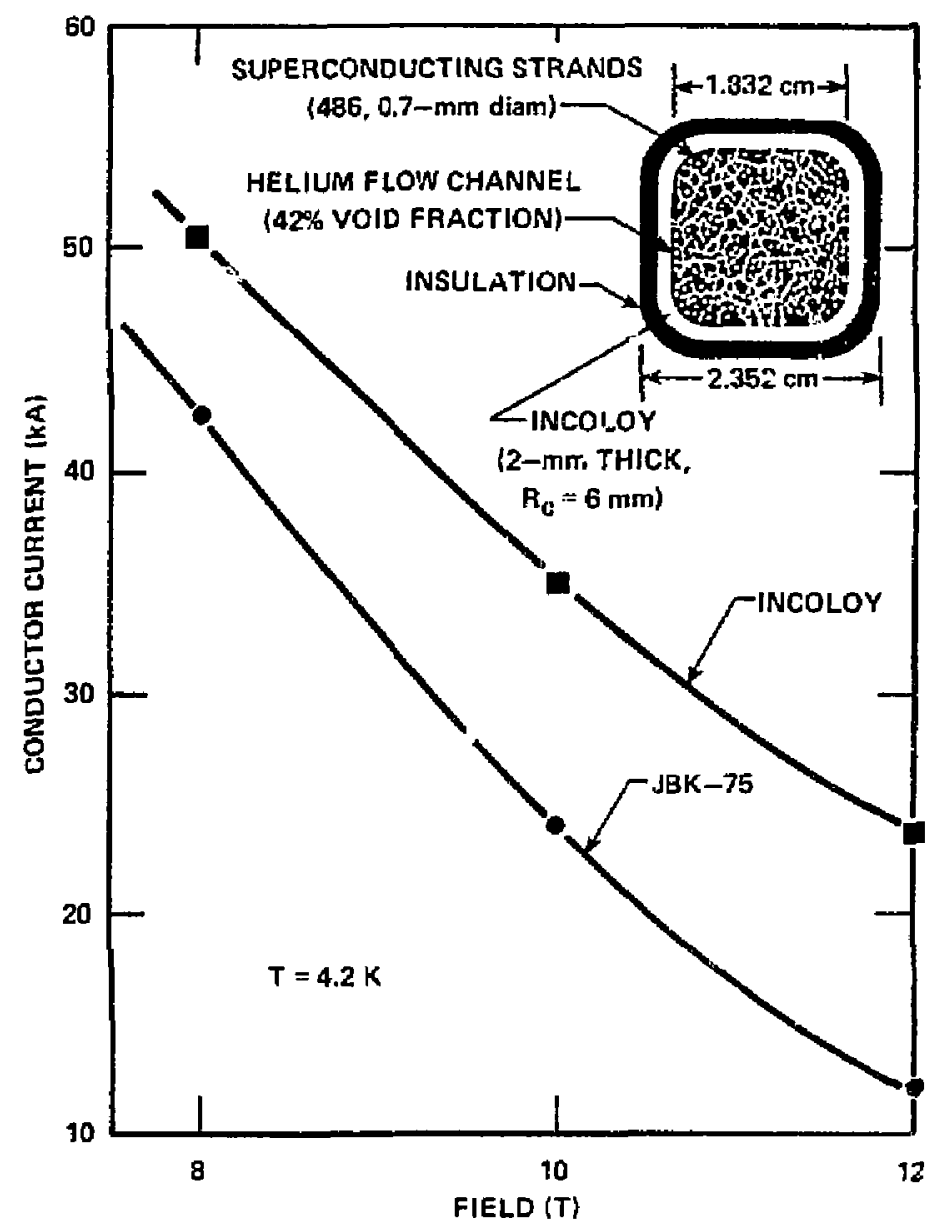

Fig. 3-16. $\mathrm{Nb}_{3} \mathrm{Sn}$ cable-in-conduit conductor. 
field, when subjected to a nuclear heating Ioad of 1 to $50 \mathrm{~mW}^{\mathrm{k}} / \mathrm{cm}^{3}$ if the following modifications are made:

1. Employ Incoloy conduit material.

2. React the conductor at $700^{\circ} \mathrm{C}$ after winding.

3. Develop inaulation capable of withstanding the required reaction temperature.

4. After winding, impregnate the stack with epoxy.

5. Provide a larger helium cross-sectional area.

6. Provide supercritical liquid helium at an inlet temperature of $3 \mathrm{k}$ if nuclear heating loads exceed $1 \mathrm{~mW} / \mathrm{cm}^{3}$.

A set of four concentric windings provide the choke field. These windings use pool-boiling conductors of $\mathrm{NbTi}_{3} \mathrm{Nb}_{3} \mathrm{Sn}, \mathrm{Nb}_{3} \mathrm{SnTi}$ ( $\mathrm{Ti}$ doped), and the before mentioned copper insert.

We chose the above conductors to best match requirements with known, or reasonable extrapolations of, current technology. However the bucking coil and mirror coil, as presently conceived, require current densities at fields beyond these criteria. Future work must be aimed at reconfiguring the coil set or developing new conductor types that can operate with current densities at the fields given in Table 3-5.

The large octopole (OCT1) consista of four saddle-shaped window-frame windings. The end of the coil facing the bucking solenoid (ABUCK) serminates in a three-step taper. End turn cancellation is provided by the bucking coil, which is radially concentric with this end of the octopole. Each segment of the large octopole is pancake wound with three conductors in parallel to limit the lengths of the cooling paths that remove the nuclear-heat loads. Electrical and cooling leads are located at the axial midplane of the coil, where the coil achieves its maximum radial dimension.

\section{Coil Structural Arrangement}

The end-cell coils react with one another and with the central-cell solenoids; these reactions result in significant loads that must be considered 
in both the lerign of the individual coils and the atructural system 1 inking the coils. For the solenoid coils, these loads are two dimenaional: axisymetric radial loads, which must be reacted in the individual coil-case structure; and axial loads (in the direction of the machine axis), which must be considered in the design of the coil interconnection scheme. For the octopole coilo, the loads are three dimensional: in-plane loads trying to dispiace the legs radially; out-of-plane loads trying to twist the legs circumferen:ially about the machine axis; and axial loads trying to displace the coils relative to each other. The radial and circumferential loads on any leg of an octopole are offset by symetrical relationships to those loads on another $\mathrm{leg}$, and, consequently, can be reacted using standalone-octopole case structure. Nate, though, that the axicl load must be reacted to an external point.

The magnitude and direction of the net axial load on each end-cell coil are shown in Fig. 3-17. Because of the relative coil positions and the loads, the coils are axially tied into two modules; the first module comprises the two octopoles, the bucking coil1, and the mis ror coil; the second comprises the choke and central-cell solenoids. The general arrangement of the end-cell coil set is shown in Fig. 3-i8.

Figure 3-19 shows a concept for the atructural linking of the four endmost coils in the end cel1. The two solenoids are structurally tied together resulting in a net load of $6 \times 10^{7} \mathrm{~N}(13.5-m i l l i o n$ pounds) that pulls the coils away from the octopole. Tying this set of coils to the octopole has many advantages including use of a minimum amount of material, no heat flow through the tie, minimized deflection when loaded, and use of the coill load to offaet the axial load pulling the octopole toward the central ce11g. The disadvatuage of this concept is that the tie must be removed to disassemble the octopole and remove the top section(s) of the octopole. Note that this disadvartage is somewhat offset by fact that the solenoids radially "lock" the tapered ends of the octopole, which necessitates some untying and moving of the solenoids in any event. As indicated in Fig. 3-19, the small octopole is axially connected to the large octopole. The bolts are installed from the outer end so that they are accessible when the top section(s) of the large octopole and necessary shielding are removed. The small octopole can be lifted through the gap that results whan one window frame is removed. 


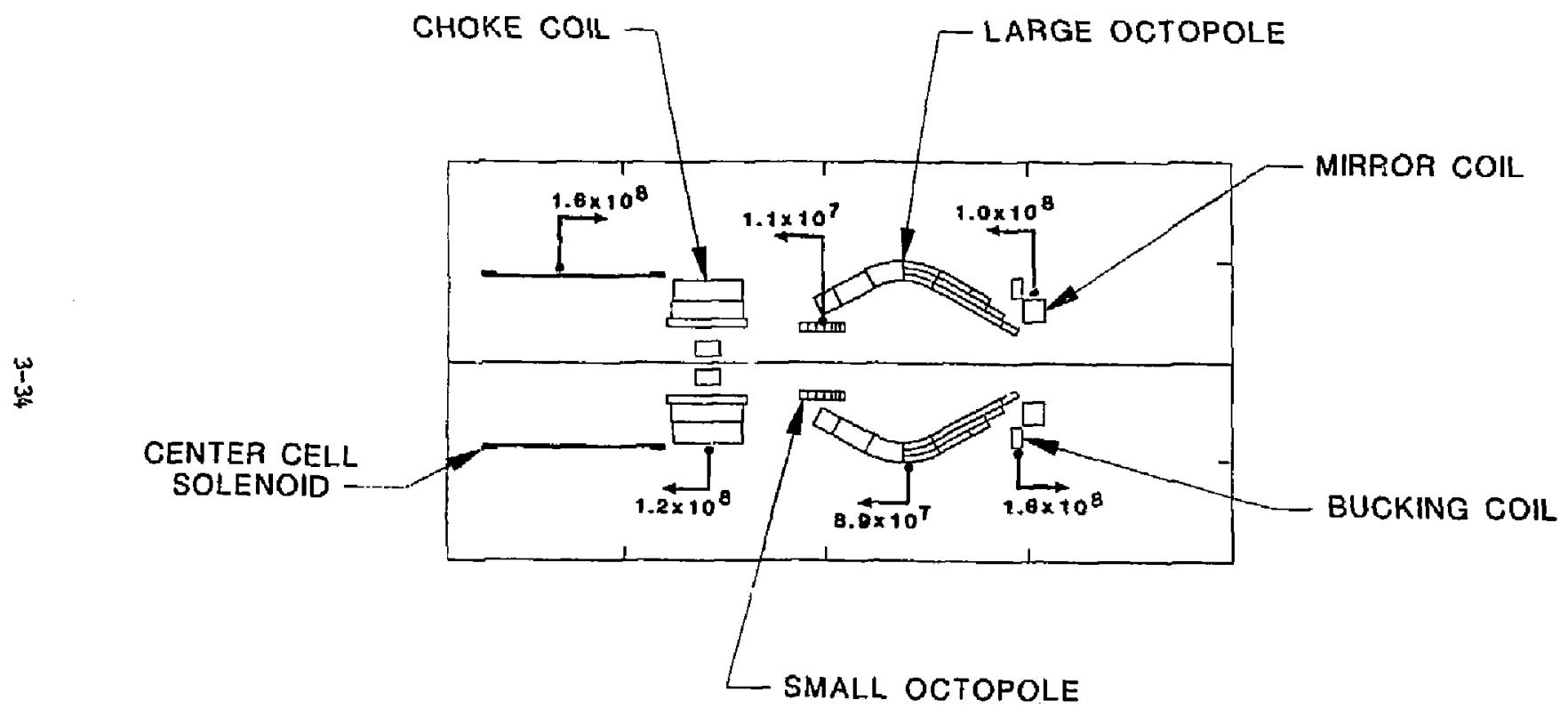

Fig. 3-17. Magnet1c net axial loads on end cell coils. 


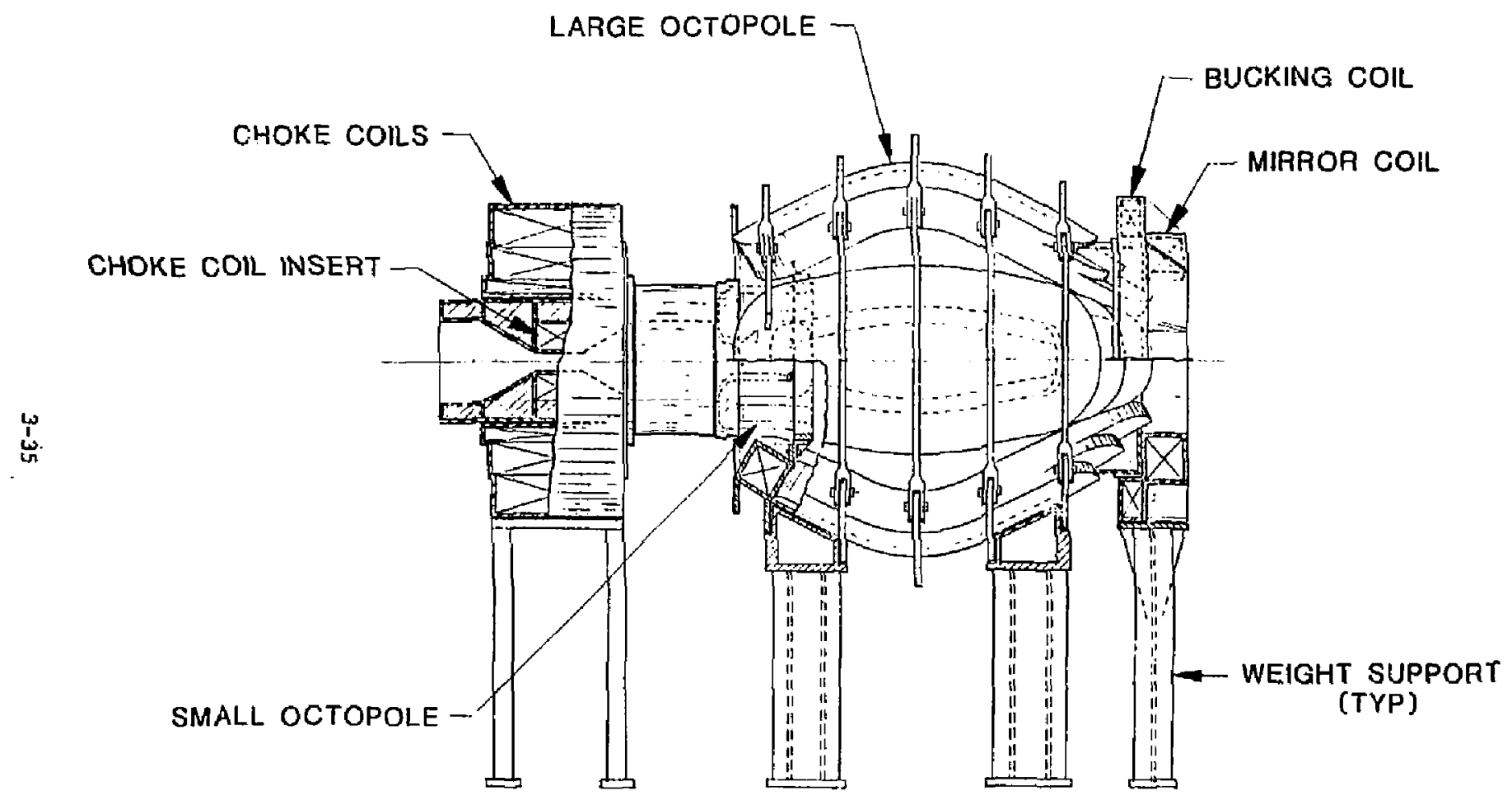

F1g. 3-18. End cell coll arrangement. 
ATTACHMENT: LARGE TO

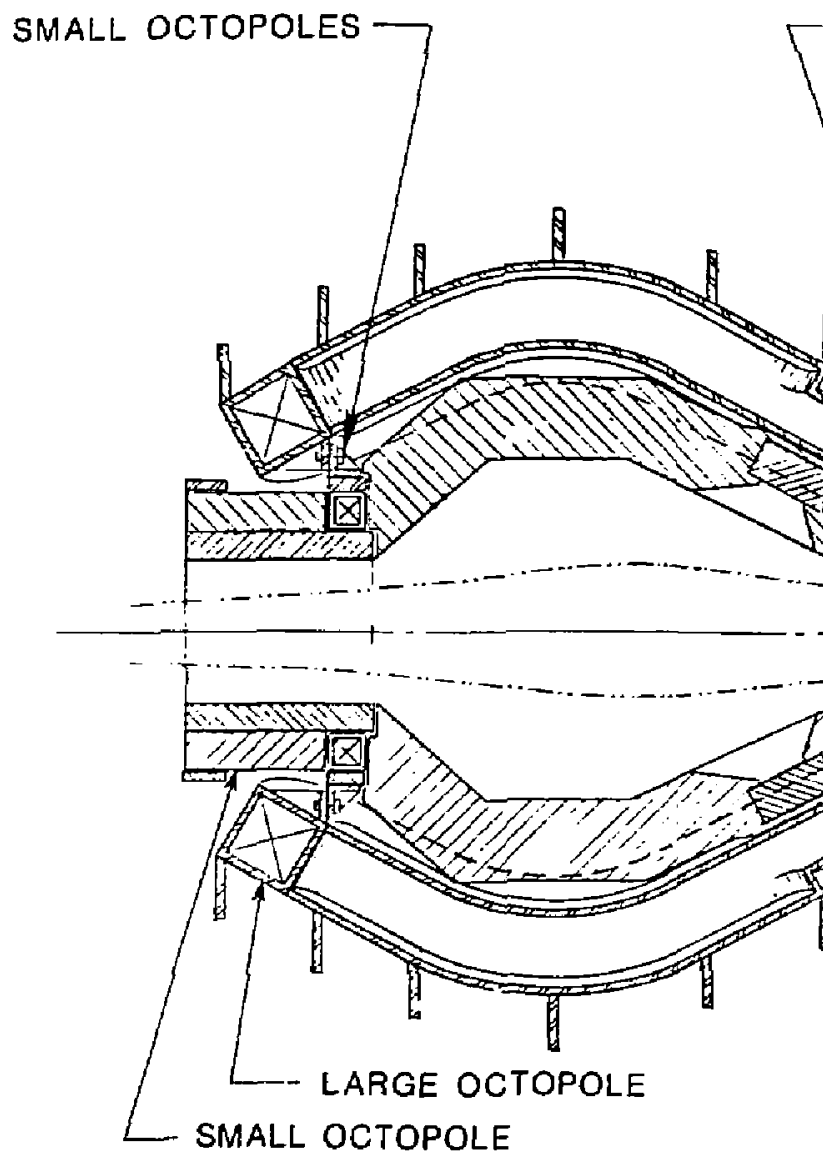

ATTACHMENT:

LARGE OCTOPOLE TO BUCKING/MIRROR COILS

Fig. 3-19. End-ce11-coil attachment schems. 
Because the large actopole is actually an assembly of four individua window-frame coil windings, we devised a structural arrangement that could be appliec to each segment individually. Along the eight axial legs of the coil, radial forces range from $4 \times 10^{6} \mathrm{~N} / \mathrm{m}$ at the coil centerlíne to $2.5 \times 10^{6} \mathrm{~N} / \mathrm{m}$ near the ends. These forces are reacted by a series of seven stainless-steel bands 7.5 to $10 \mathrm{~cm}$ thick and renging in height up to $38 \mathrm{~cm}$ above the coil case. A 5-cm-thick skin bridges the upper and lower surfaces of the axial legs of the octopole. The skin is not only used to transfer the radial loads into the bands, but also to react the circumferential loads trying to push the two legs apart. The skin, when considered in connection with the 5-cti-thick case around each winding, forms a beam-1ike structure for transfe-11 of the axial loads from the linked solenoids.

The bands on individual window-frame segments are joined at assembly to complete the required circumferential tie. The bands are positioned so that they do not interfere with the heating requirements. These bands access the plasma through holes provided in the upper and lower skins. Note that a great portion of the loads on the axial legs of the large octopole arises from the leg curvature; i.e., the lege are not parallel to the machine axis, but rather form an arc ranging from 1.5 to $2.3 \mathrm{~m}$ away from the axis. The typical window frame-segment structural arrangement is shown in Fig. 3-20.

The small continuously-wound superconducting-octopole magnet, approximately $200 \mathrm{~cm}$ in diam by $120 \mathrm{~cm}$ in length, is located under the entrance to the large octopole. Its position, relative to the circumferential legs of the lafge octopole and the choke coils, results in significant radial ioads on the magnet's crossover windings as well as circumferential loadings on its axial iū̌s. The radial loads on the axial legs, although reversing direction along the winding length, are smaller. Stainless-steel bands are again employed to react the radial loads. Bands (each $27 \mathrm{crn}$ wide, which is the full width of the coil winding and case) are required at both ends of the coil. At the end toward the large octopole, a band thickness of $9 \mathrm{~cm}$ is required. Because of radial space constraints, the required $11-\mathrm{cm}$-thick band on the efge near the choke coils is divided into rings on both the upper and lower winting aurface, which are tied together in the gaps between circumferential coil legs. Our analysis shows that the $2.5-\mathrm{cm}-\mathrm{thick}$ coil case 


$$
8
$$


surrounding the winding is sufficient to react the loads ot the coil's axial legs without additional structure. The required case structure is shown as Fig. 3-21. The module, consisting of the two octopr tes and the two solenoids, is attracted toward the choke coil by a net axial load of $4 \times 10^{7} \mathrm{~N}$. This load could be reacted either through tie rods to the vacuum tank or through the support structure to either the tank or the choke-coil.

The choke-coil set, consisting of a radial stack of four windings, is attracted toward the central-cell solenoids with a force of $1.2 \times 10^{8} \mathrm{~N}$ (27-million pounds). However the solenoid is attracted toward the end-cell magnet set with a force of $1.6 \times 10^{8} \mathrm{~N}(36$-million pounds), which means that if the two were tied together a net load of only $4 \times 10^{7} \mathrm{~N}$ would need to be reacted by external structure. The method for making this coil-to-coil tie and the method of reacting the resultant load will have to be addressed in future work. Possible schemes for the latter problem include:

1. Use the central-cell intermodule connection scheme to tie choke coila from opposite ends of the device together (the resu'ting tension load would offset the axial-compression vacuum load of $5.5 \times 10^{6} \mathrm{~N}$, which would result in a more desirable tension load across the joints).

2. Use the structure supporting the coils to trangfer the loed to the vacuum tank,

3. Use a auxiliaxy structure tied to the octopole coil module and the choke coil. (The choke and octopole coils have an opposite and equal net load.)

HEATING SYSTEMS

The heating aystems for an octopole tandermirror configuration differ someshat from those required in the MARS configuration, ${ }^{1}$ as studied in FFD-I and FPD-T1. ${ }^{2}$ The conversion from the double pair of quadrupole magnets on the end cell to the octopole magat pair, exchanges the high-beta anchot region created by an ion-cyclotron resonant heating (ICRH) system for a hot-electron mantle maintained by an electron-cyclotron resonant heating 


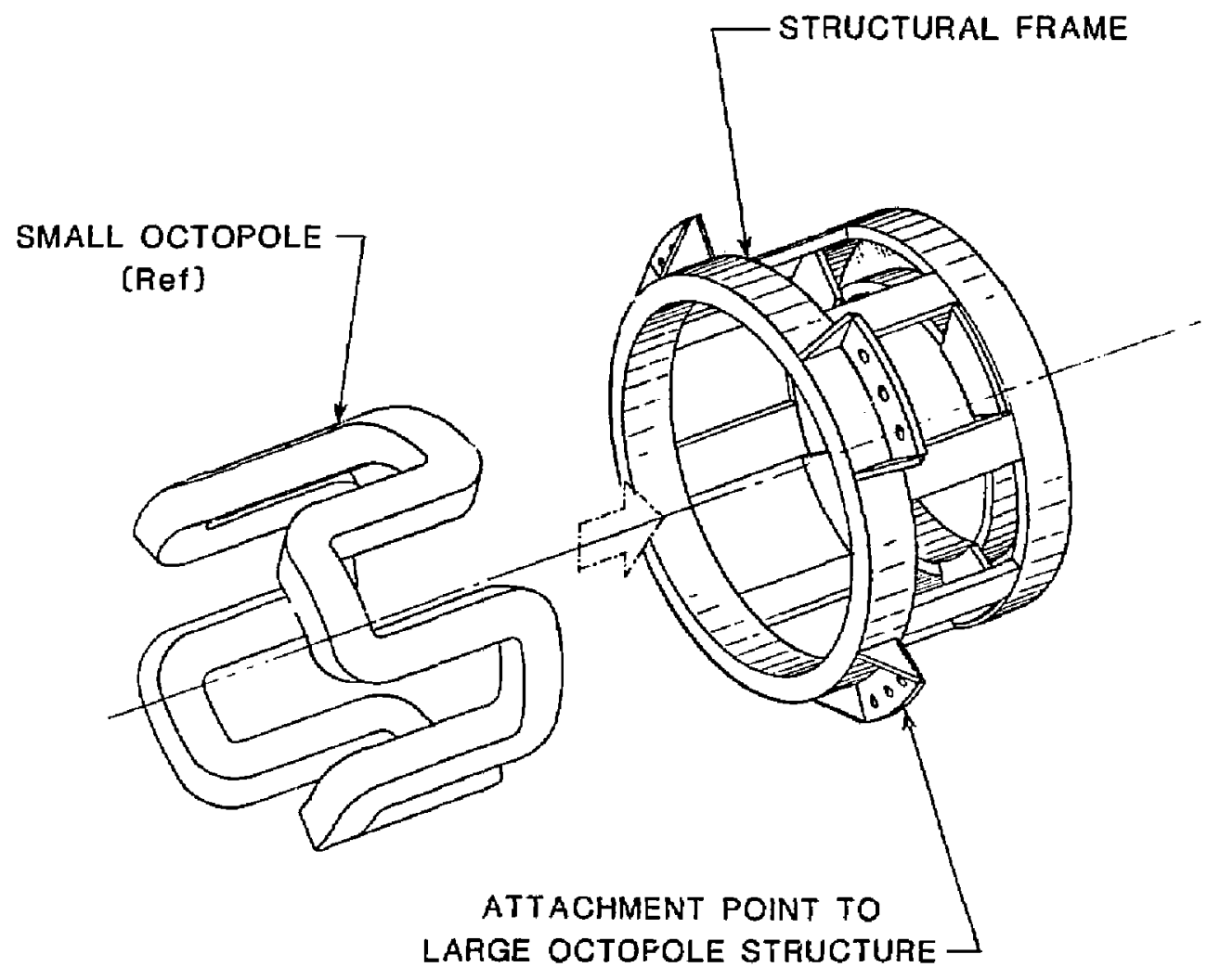

Fig. 3-21. Frame for small octopole. 
(ECRH) sygtem. The mainstay components of the tandem mirror plug (i.e., the ECRH-heated thermal barrier and potential peak, the drift pump systems, and the high-energy neutral-beam-produced sloshing-ion distribution) all remain intect.

The power requirements of the two ECRH systems and the negative beam system that are common to both the MARS and FPD configurations decreased in FPD-III with the octopole. However, most of the ECRH power reduction is offset by the addition of the mantle ECRH power requirement. Table 3-6 summarizes the FPD-III injection-system requirements. The primary differences between the mantle system and ECRH systems designed to date are the following: the factor of three frequency excursion during startup; the relatively low-heating frequency of about $10 \mathrm{GHz}$; and the annular nature of the region heated by the system. The two frequency features result from the 1.3-T field minimum in the mantle and the very high peak-rantle beta of $90 \%$. A schematic of the mantle is shown in $\mathrm{Fig}$. 3-22.

The drift pump requirements in Table $3-7$ are those defined for an early version of MINIMARS. Two regions under the small octopole must be puraped: (1) the core plasma, which is nearly circular; and (2) the edge region, which is made up of the portion of the halo that is not intercepted by the choke coil. We assume that the edge region is similar in shape to the electron mantle shown in Fig. 3-22. The above two regions require significantly different launcher concepts, both with respect to each other and compared with the drift-pumping systems for MARS, ${ }^{1}$ FPD-I, 2 and FPD-II. ${ }^{2}$

\section{ECS}

For the three ECRH systems, a total of 17.9 Mh must be de1ivered to the plasma. The basic systen configaration for each end plug consists of one 25-NW transformer/converter and thirteen paralle1-protection and voltage-regulation networks for the gyrotrons. Each gyrotron is followed by a waveguide interface section and a beam launcher. Figure 3-23 depicts the plan view of the endcell heating-system configuration.

The thermal-barrier system has two quasi-optical transport vessels per end plug; these transport vesaels extend from the reactor vacuum vessel. Each 
Table 3-6. The FPD-III heating syatem requirements.

\begin{tabular}{|c|c|c|c|c|}
\hline & $\begin{array}{l}\text { Sloshing } \\
\text { N INB }\end{array}$ & $\begin{array}{c}\text { Mantle } \\
\text { ECRH }\end{array}$ & $\begin{array}{l}\text { Potential- } \\
\text { peak } \\
\text { ECRi }\end{array}$ & $\begin{array}{c}\text { Thermal- } \\
\text { barrier } \\
\text { ECRH }\end{array}$ \\
\hline Heating locations & $a^{\prime}$ & $90-\mathrm{cm}$ off axis & a & $\mathbf{b}$ \\
\hline$z_{\text {axis }}(\mathrm{m})$ & \pm 19.9 & \pm 22.2 & \pm 23.2 & $\pm 22,2$ \\
\hline Ab sorbed power (MW) & 0.13 & 6.22 & 0.16 & 5.42 \\
\hline Trapping fracsion & 0.082 & 0.75 & 0.85 & 0.70 \\
\hline Delivered power $(M W)$ & 1.61 & 8.30 & 0.19 & 7.75 \\
\hline Vacuum frequency $(\mathrm{GHz})$ & - & 36.4 & 58.8 & 42.0 \\
\hline Peak beta & -- & 0.90 & 0.216 & 0.33 \\
\hline \multicolumn{5}{|l|}{ Heating frequency ( $\mathrm{GHz}$ ) } \\
\hline (harmonic) & -- & i1.5 & 52.0 & 34.4 \\
\hline Delivered current ( & 3.4 & -- & -- & -- \\
\hline Beam energy (keV) & 475 & -- & -- & -- \\
\hline
\end{tabular}




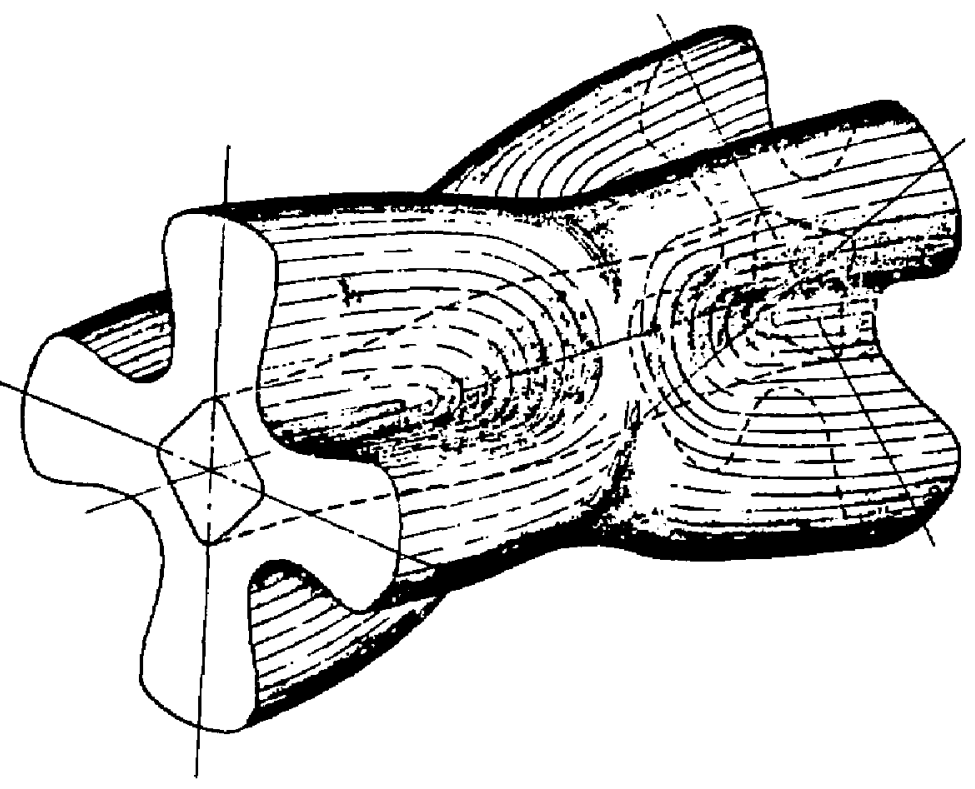

Fig. 3-22. Octopole hot electron mantle and plasma core. 
Table 3-7. Drift-pumping requirements for FPD-III.

\begin{tabular}{|c|c|c|c|c|c|c|}
\hline & & & $\begin{array}{c}\text { Frequency } \\
(k \text { ( } z)\end{array}$ & $\begin{array}{l}\text { Field } \\
\text { (G) }\end{array}$ & $\begin{array}{c}\text { Current } \\
\text { (kA) }\end{array}$ & $\begin{array}{l}\text { Power } \\
\text { (kw) }\end{array}$ \\
\hline \multirow[t]{4}{*}{ A. } & Edge & $I$ & 155 & 165 & 5.2 & -- \\
\hline & & 2 & 200 & 165 & 5.2 & -- \\
\hline & & 3 & 245 & 165 & 5.2 & -- \\
\hline & & 4 & 290 & 165 & 5.2 & -- \\
\hline & Core & 0 & 330 & 80 & 2.8 & -- \\
\hline & & 5 & 450 & 8 & 0.28 & -- \\
\hline & & 6 & 7000 & -- & $\rightarrow$ & 160 \\
\hline
\end{tabular}




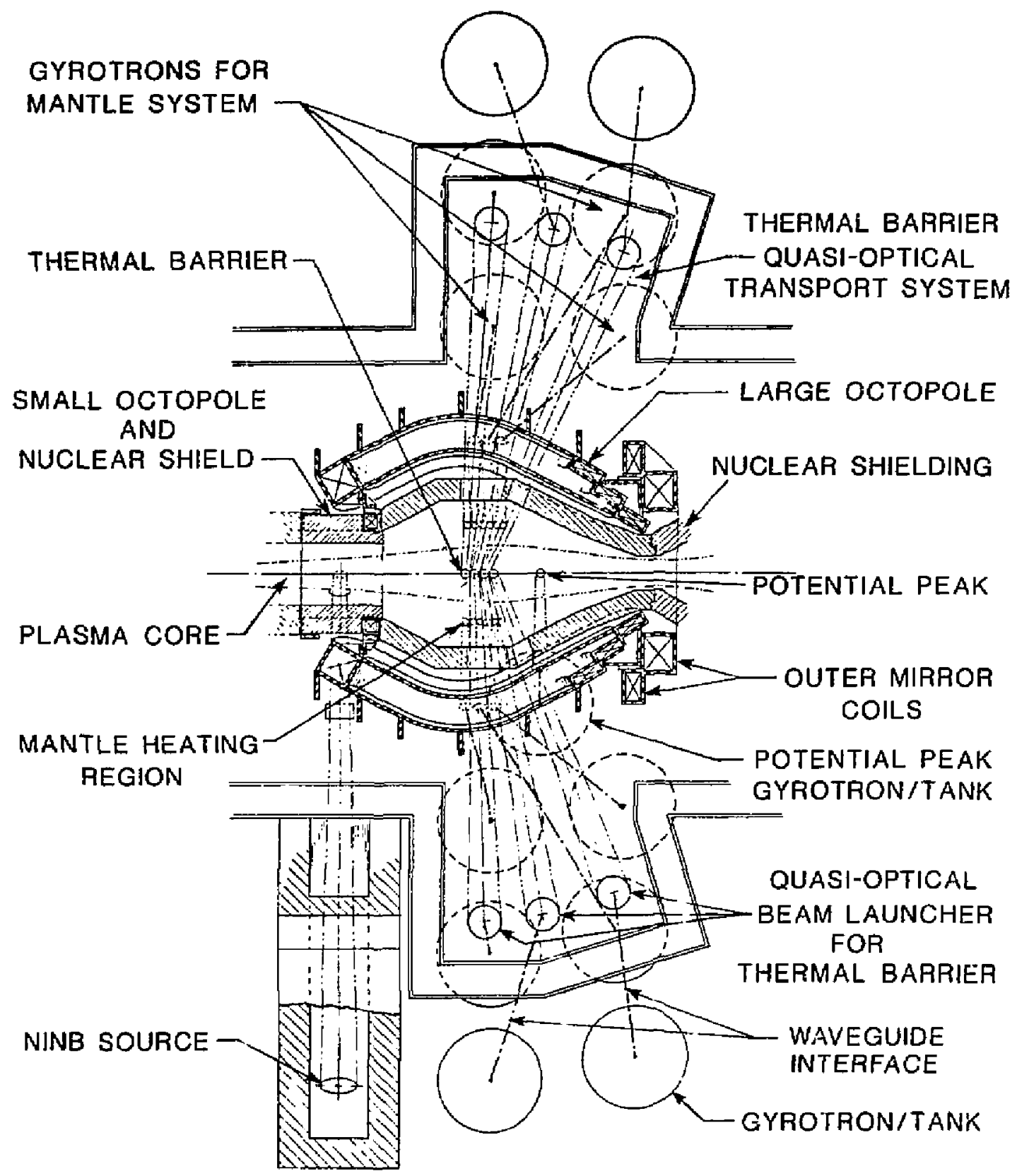

Fig. 3-23, ECRH/NI: snd-ce11 configuration plan view. 
ECRH vessel has three beam launchers that consist of an offset conical horn and parabolic reflector. The reflector surface is modulated to apply a phase correction that convercs the TEO1 waveguide mode into a Gausian intensity pattern. These FPD-III reflectors are similar to those used on Tandem Mirror Experiment-Upgrade (TMX-U) ${ }^{3}$ and those planned for Mirfor Fusion Teat Facility (MFTF-B). ${ }^{4}$ The waveguide interface between the gyrutron and the beam launcher is primarily for mode control; a block diagram of the waveguide interface is show in Fig. 3-24. The 1-l/W gyrotrons operate at a reduced 840-kW 1eve1. We assume that the entire system, gyrotron cu rtactor vesse1, is in a vacunm with gate valves located at the gyrotron, the waveguide/launcher interface, and the ECRH/reactor vessel interface.

The mantle and potential-peak systems" beam launchers are located inside the reactor vacuum vessel. The waveguide interface penetrates the vessel wall to the launcher. The mantle gyrotrons operate at a power level of $908 \mathrm{kw}$, whereas the low-power requirement for the potential permits the use of existing 200-kH gyrotron technology.

The total power to the gyrotrons is $46.6 \mathrm{MW}$ at $80 \mathrm{keV}$; the power supply is $94.6 \%$ efficient so that the 1 ine-power requirement io about $49.3 \mathrm{MW}$. Auxiliary requirements include cooling water (about $9500 \mathrm{~g} / \mathrm{m}$ ), liquid nitrogen (about $26 \% / h$ ), and liquid helium $(13 \mathrm{\ell} / \mathrm{h}$ ).

\section{Sloshing-Ion Neutra1-Beam System}

The negative-ion-baged neutral-bean system, wilich creates the sloshingion distribution, delivers $1.7 \mathrm{~A}$ of deuterium at an energy of $475 \mathrm{keV}$ into each plug. The FPD-III beamline configuration is similar to those beamines described in the FPD-I atudy. ${ }^{2}$ Each end cell has one beamline with one source per beamline. Because the octopole magnets at one end of PPD-III are rotated $45 \mathrm{deg}$ relative to the other end, one beamline is on the device midplane, while the other beamline is injected at $45 \mathrm{deg}$ below the midplane. The cross section views of the two end cells are shown in Figs. 3-25 and $3-26$. 

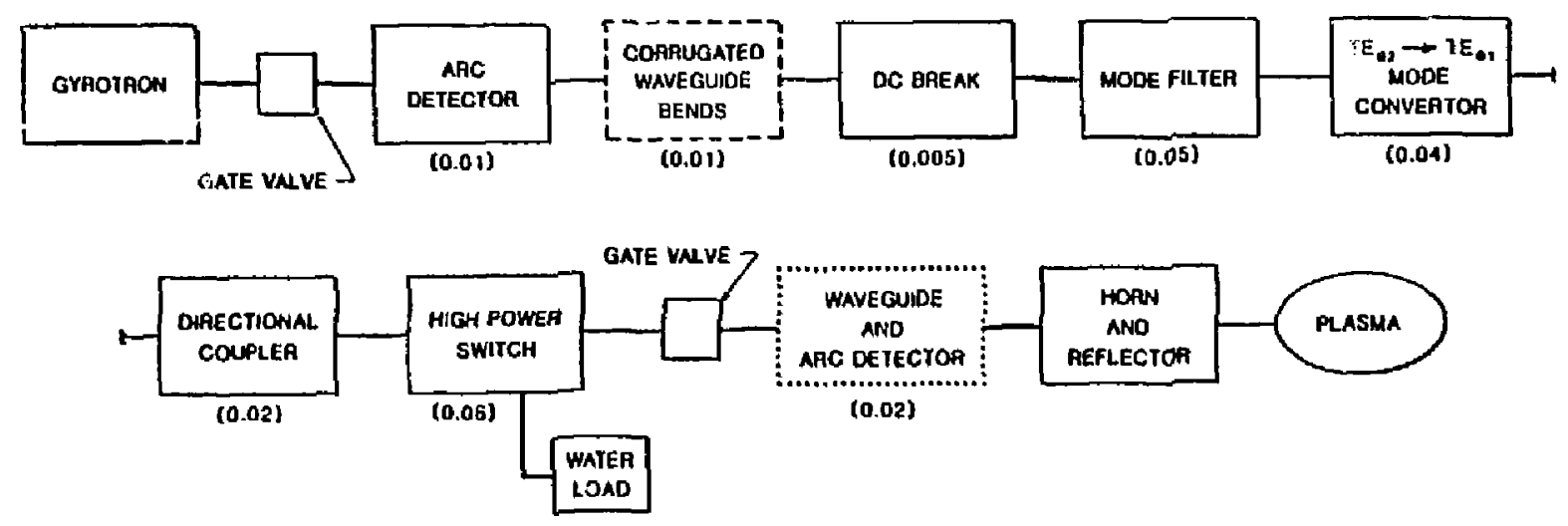

$w$
1
\pm

\begin{tabular}{|c|c|c|}
\hline & $\begin{array}{l}\text { MANTLE AND } \\
\text { POTENTIAL PEAK }\end{array}$ & THEFIMAL QARFIEA * \\
\hline TRANSMISSION EFFICIENCY & $76.5 x^{+}$ & $\begin{array}{l}00.5 x \\
01.5 x\end{array}$ \\
\hline BEAM LAUWICHER EFFICIENCY & $97 \mathbf{x}$ & $95 x$ \\
\hline
\end{tabular}

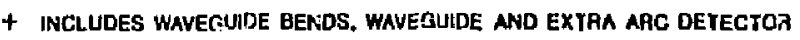

* ONE half of the LINFS include waveguide gends and hllf do not

$\therefore$ ig. 3-24. ECRH wavegulde interface and transmission systems. 


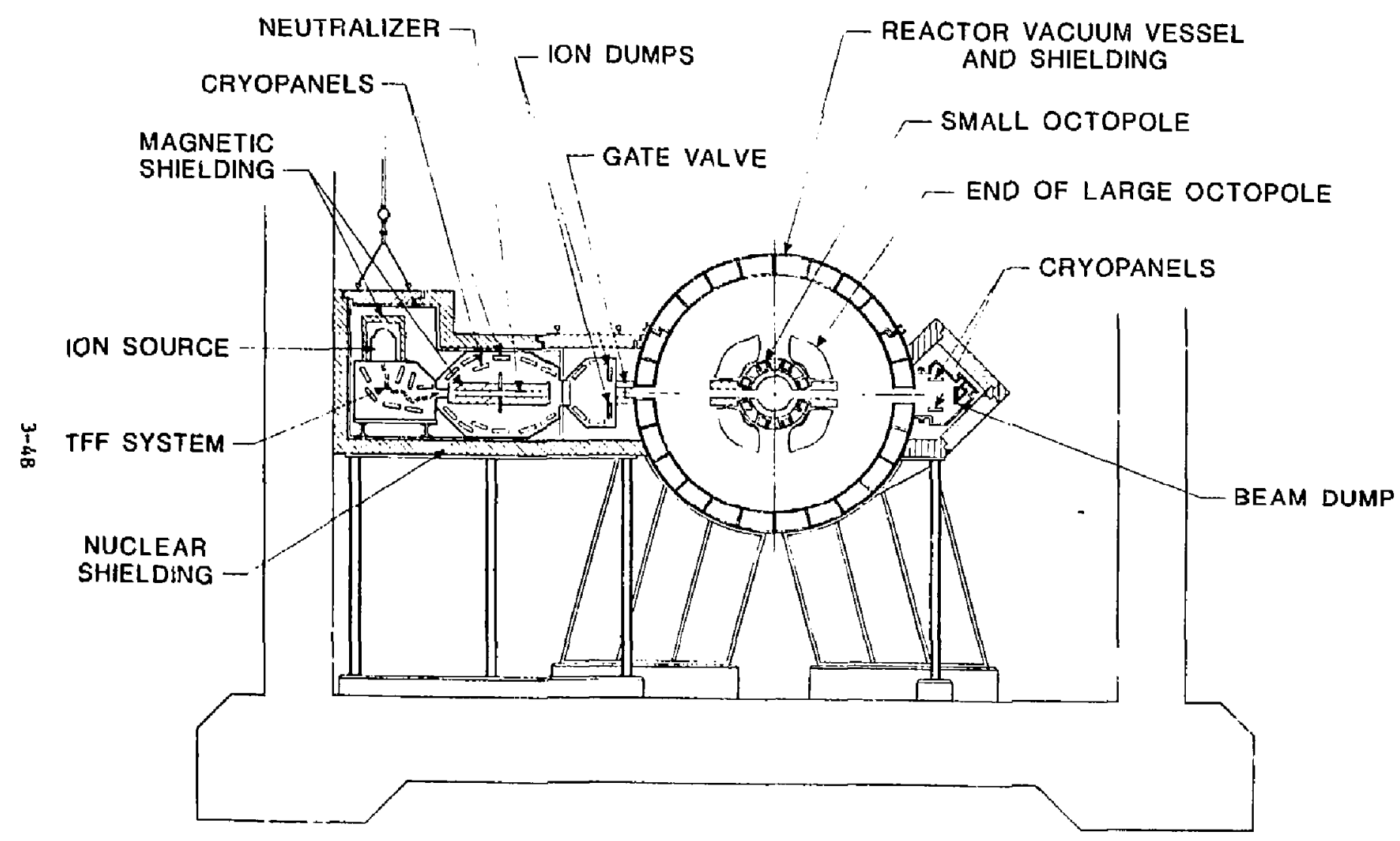

FIg. 3-25. Sloshing-1on neutrai-beall cross-section view--east end. 


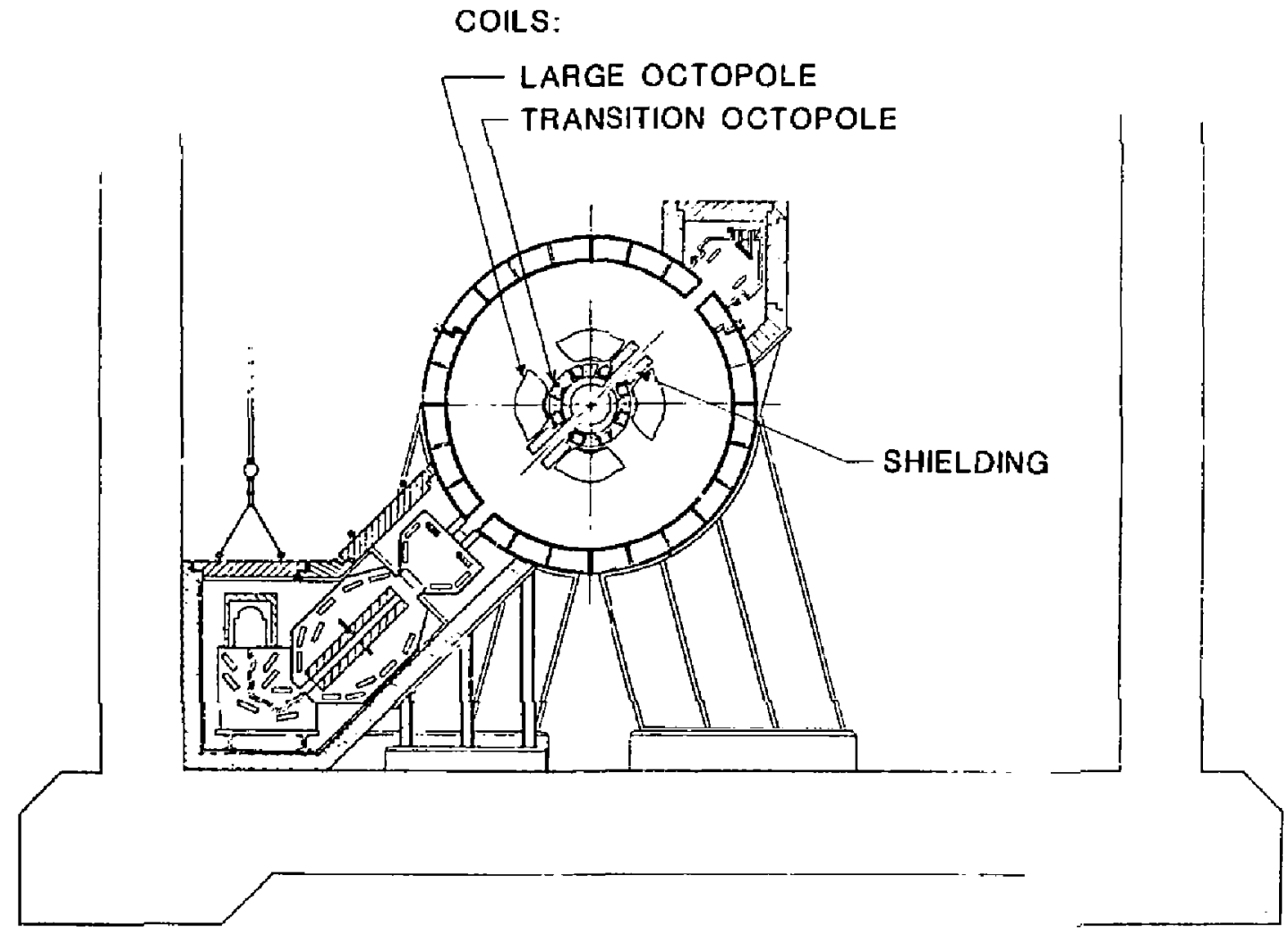

Fig. :-26. Sloshing ion neutral bean cross section view--west end. 
A Lawrence Berkeley Laboratory (LBL)-type, self-extraction negative-ion source produces 4.D6 A. Because the syatem must be steady otate, we assume that the source plasma is generated by $\mathrm{rf}$, and that the cesium is forced through the porous converter plate from the back of the plate to keep the cesium coverage uniform and congtant with time. The source gas efficiency is 12\%. The ribbon beam is $65 \mathrm{~cm} \times 2 \mathrm{~cm}$ in cross section and has a one half degree divergence. Fifteen percent of the current is lost in the $80-\mathrm{keV}$ slotted pre-accelerator, and another $11 \%$ is 10 st in the 475 -keV transverse field-focusing transport and accelerator system.

For FPD-III, we replaced the gas-jet neutralizer in FPD-II with a standurd gas-duct neutralizer becaube we did not find an atrractive solution for pumping the huge gas load of the jet neutralizer. The neutralizer efficiency is $61 \%$ and the target thickness for $475 \mathrm{keV}$ is $6.5 \times 10^{15} \mathrm{~cm}^{-2}$. The gas load from the source and the neutralizer is 5.5-T $l j s$. The beamline pressure must be less than $2 \times 10^{-5}$ Torr. For a maximum pumping speed of $B \times 10^{4} \mathrm{l} / \mathrm{s}$ and a $20 \%$ recycle factor, the cryopanel area must be $4 / 1 \mathrm{~m}^{2}$.

After passing through the neutralizer, the remainir from the beam as the ions pass through a bending magnet. The power of the ions is deposited on two ion dumps. The $\mathrm{D}^{+}$and $\mathrm{D}^{-}$dumps collect $360 \mathrm{kt}$ and $200 \mathrm{~kW}$, respectively. We assume that a $1 \mathrm{~m}^{2}$ cryopanel is adequate for the gas load in the dump region. Eight percent of the neutral-beam current is lost as the beam passes through the magnet, apertures, and drift duct. Since only $8.2 \%$ of the bean is trapped in the plasma, $1.45 \mathrm{~A}$ or $690 \mathrm{~kW}$ is deposited on the neutral-beam dump.

Auxiliary requirements for the entire system include $750 \mathrm{~g} / \mathrm{m}$ of cooling water, $55 \mathrm{l} / \mathrm{h}$ of $\mathrm{LN}_{2}$, and $19 \mathrm{\ell} / \mathrm{h}$ of LHe 2 . The beemline curzent efficiency is $41.9 \%$, whereas the power efriciency is $43.7 \%$. The 1 ine-power requirement is thus about $3.7 \mathrm{MW}$.

\section{Drift Pump Systems}

The drift pump syatems perturb the geddesic curvature in the end cell to enhance the radial trift of various ion apecies that become trapped in the end plug. We assume that the plasme in the small octopole is similar in shape to 
the hot-electron mantle shown in Fig. 3-22. Figure 3-27 depicts this density profile. The system is segregated into components that pump the core and edge regions. The flat density profile in the core region requires a narrow bandwidth, $\Delta W / W=0.01$, and three frequencies for pumping the three species of concern. On the other hand, the edge region requires a large bandwidth, $\Delta W / W=0.5$, which we accomplish by using four frequencies.

We chose a scaled version of the TARs slot antenna at MIT to pump the core region of FPD-III. Two slots form a pair of coupled coils, which are driven in phase. We estimate the flux through each slot based on a uniform field across the slot. Figure 3-28 depicts the antenna and matching network. Each core transmitter channel is matched to the drift-pump coil (DPC) with a resonant circuit. The vacuum $Q$ of the coil is approximately 400 , or the plasma load for these frequencies is nearly zero. The transmitter efficiency is about 65\%, and the matching network efficiency for the DPC is $25 \%$. The total prime-power requirement for the core system is $2.12 \mathrm{MW}$.

The edge-drift-pump system consists of four split-coax sections in each end cell. Each coax is driven by one of the four drive frequencies and follows the peak of the plasma lobe. The coax is $10 \mathrm{~cm}$ in diam, $0.5 \mathrm{~m}$ in length, and has a azimuthal split of $60 \mathrm{deg}$. The prine power requirement for each tone is approximately $1.25 \mathrm{MW}$; the total power for the system is $10 \mathrm{MW}$.

IND CELL SHIELDING

The end cell shielding consists of the magnet shields, penetration shields, and biological shield. The biological shield consists of the double-walled vacuum vessel and the water that is held between the 111 s. The purposes of the end-cell shielding follow:

1. To reduce the nuclear heating of the superconducting masnets.

2. To p-event excessive radiation damage to the magnets ard other components.

3. To provide for personnel access to the reactor hal1 24 hours after shutdown. 


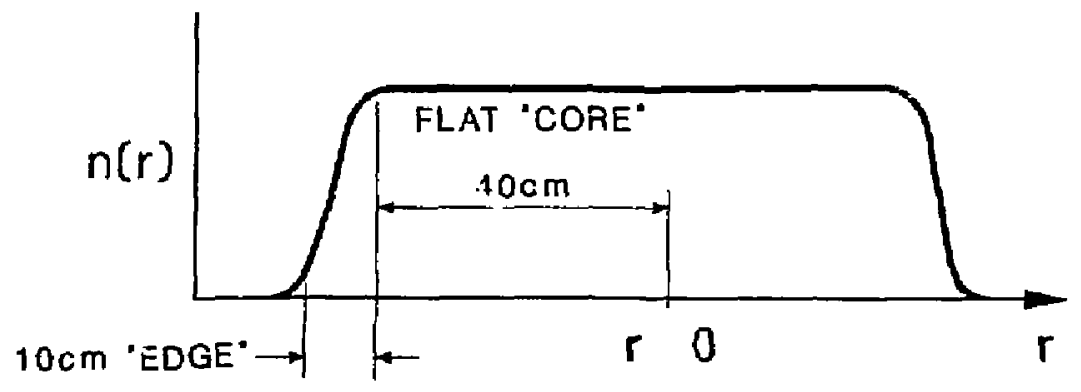

Fig. 3-27. Density profile of the plasma in the small octapole. 

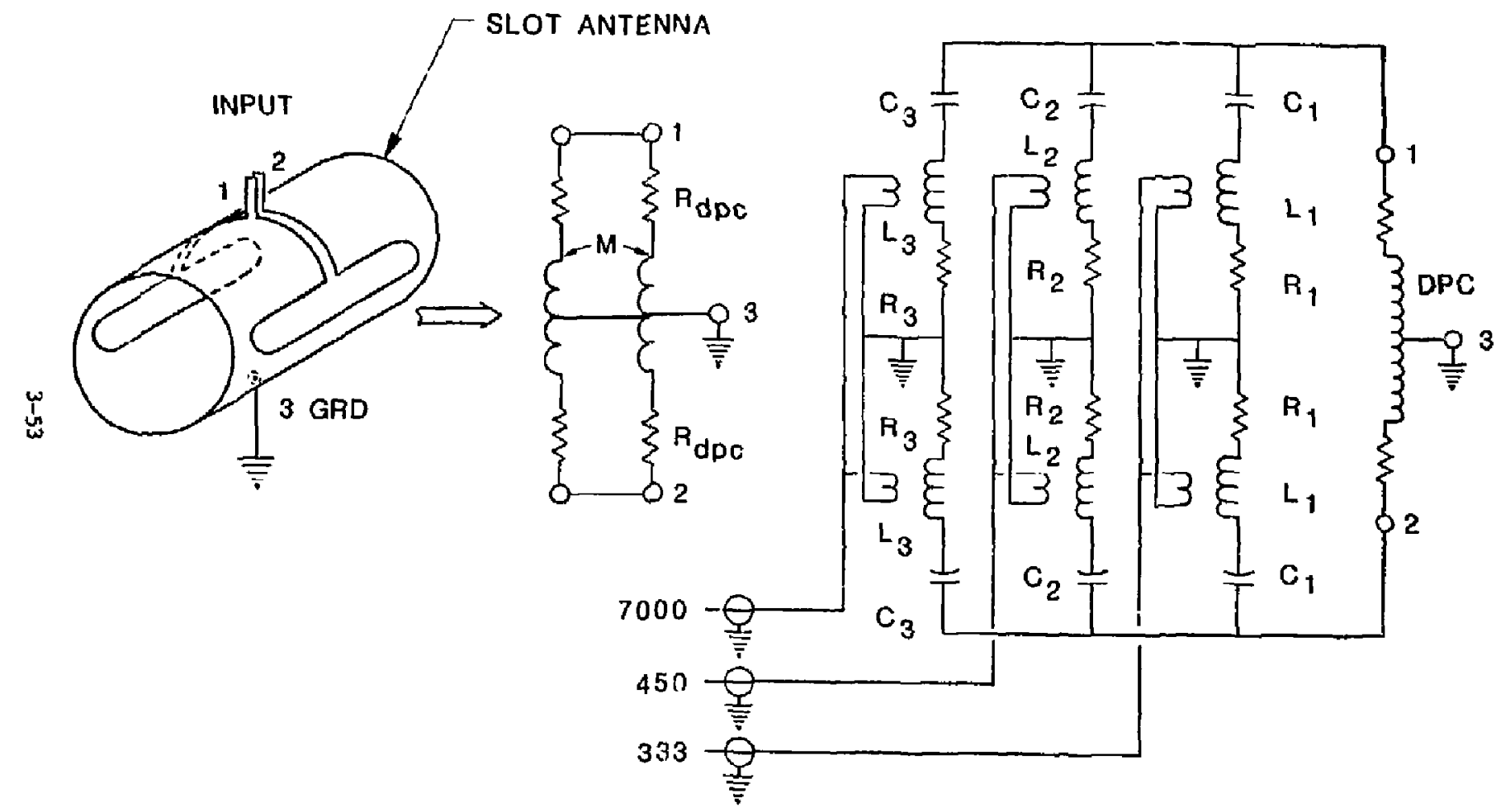

Fig. 3-28. Drift pump antenna and matching network. 
To minimize cost and maintain performance, we used steel and water shielding wherever possible. We employed tungsten shielding only in areas where space was too restricted for other materials. All of the shielding ingide the magnec envelope is water cooled. This shielding if supported away from the magnet cold mass. It is supported by warm structure between the small actopole and the choke coil and the mirror coil shield. The shielding connects to supports that penetrate the structural shell of the large octopole. This shield must be segmented for remote assembly and disassembly. These features make the detail design very complex; and we have not addressed the assembly techniques in this study.

\section{Penetration Shielding}

Penetrations are a specia! problem in the end cell because many are required for the various heating systems and space is limited. All beamlines and othex penetrations must be fully enclosed with adequate shielding to prevent otreaming neutrons from activating components outside the vacuum vessel. We have not performed a detail design or analysis on penetration shielding, however, we can make some general statemen's. Where penetratiuns expose superconducting magnets to "hot spots", a tube-like steel shield will surround the beam. In especially restricted space, the tube will require some tungsten. Outside the envelope oi the magnets, we will have more flexibility in the design aud choice of materials for the penetration shield.

\section{Large Octopole Shield}

To reduce the nuclear heat load on the large octopole to an acceptable level, we must provide shielding equivalent to a $35-\mathrm{cm}$ thickness of $80 \%$ tungeter, $20 \%$ stee:, and $10 \%$ water by volune. To achieve these shielding requirements, $60 \mathrm{~cm}$ of water-cooled stet 1 plate is used in areas where enough space is available. In places where the plasma mante restricts the shield thicknese, we apply $35-\mathrm{cm}$ tungsten inserts; this arrangement is shown in Fig. 3-29. Detail design of this shield will require a very close integration of both the magnet cold structure and the plasma mantle surface. The detail 


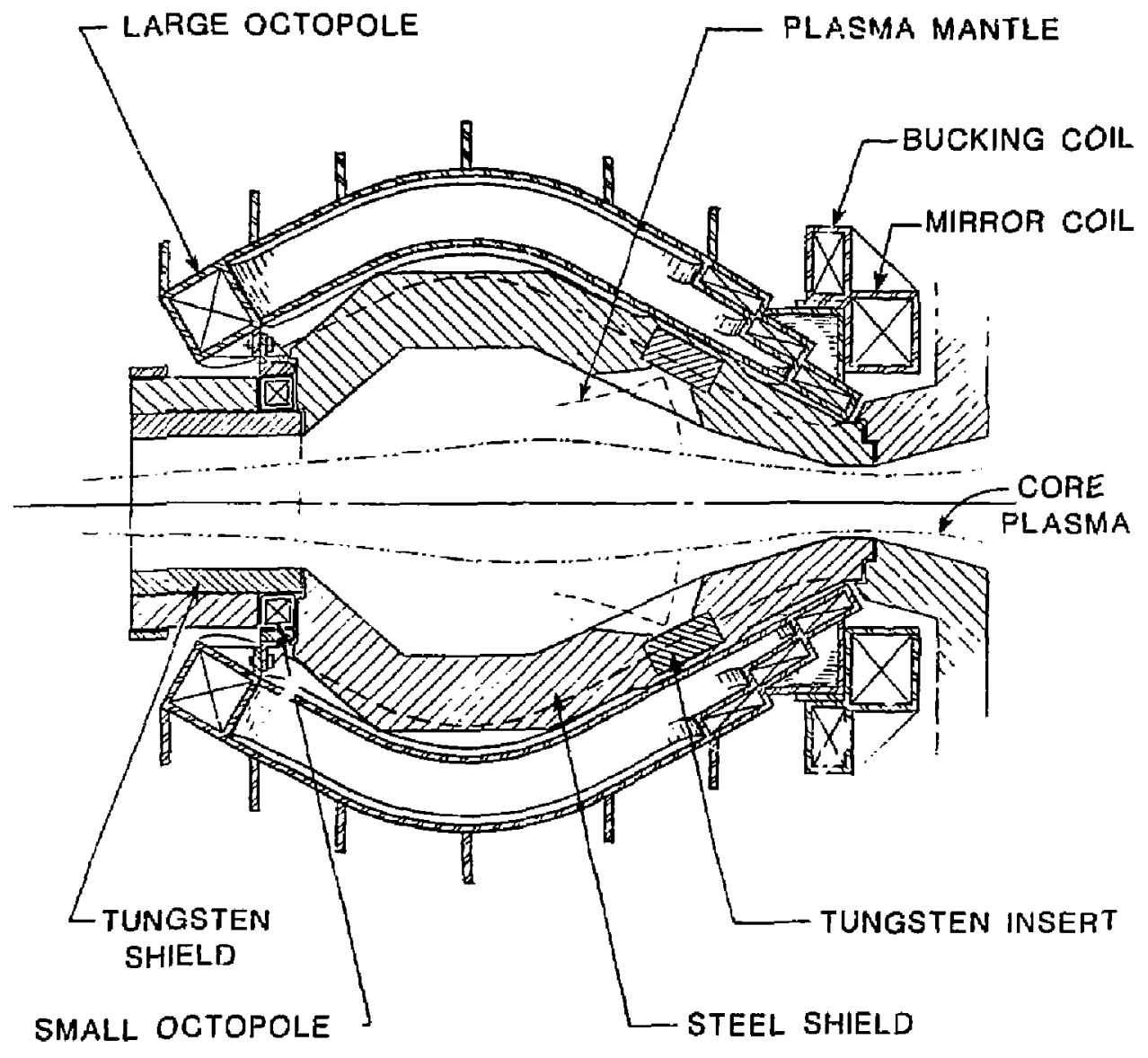

Fig. ?-29. End-cell nuclear-shield arrangement. 
design should also address the impact of the shield on vacuun-pumping performance.

\section{Sma11 Octopole Shield}

The small octopole in FPD-III is designed to operate with a higher nuclear-heat load than the other superconducting coils. A 24-cm-thick cylindrical tungsten shell through the throat of the coil provides the shielding for this small octopole. The shield consists of $80 \%$ tungsten, $10 \%$ steel case, and $10 \%$ volume for water coolant. The space between the legs of the small octopole is filled with water-cooled steel plate to increase the effective shielding to the ends of the large octopole.

The shield between the small octopole and the choke coil, plus the shield through the throat of the end-mirror coil provide structural support for the other shield sections. These shield sections are supported on warm platforms. To fill the oteel gtructure, steel balls are used as a shield in these regions because space is not restricted.

\section{Choke-Coil Shield}

The shielding through the throat of the superconducting-choke-coil assembly is provided by water-cooled steel plate. The copper-insert coil also provides shielding for the superconducting coil. The steel-plate shield Extends down along the sides of the copper-insert coil and protects it to some degree from direct radiation coming from the central coll and the end cell. The minimum effective shield thickness for the superconducting coils is $55 \mathrm{~cm}$. The gap between the choke coil and the central cell is filled with a steelbalis-type shield, which also provides structural support for the shield and copper insert coil.

\section{HALO SCRAPER/DIRECT CONVERTER DESIGN}

When we redesigned the FPD-III end cell to include octopole magneta, the direct-converter configuration benefited becarse the octopoles altered the 
plasme cross-sectionel shape making it possible to design all the direct converter element a flat plates. In this section, we report on our supporting studies concerning plasma shaping materials, sputtering, radiolytic corrogion, coolant corrosive wear, electrical insulation, and tritium permeation.

\section{Design Assumptions and Requirements}

The assumptions made for FPD-II ${ }^{2}$ are used for FPD-III. Table 3-8 gives the thermal and electrical power absorbed by the direct converter. One of our major objectives was to produce a low-cost direct. converter requiring ro' special remote handling equipment.

\section{p lasma Shaping}

The plasma cross-sectional shape resulting froth the effects of an octopole end-cell shape (Fig. 3-30) is constant in the region of the direct converter. After passing through the end mirror coils, the plasma crosssectional area increases, and the rate at which this area increases determines where the direct converter can be placed to satisfy the thermal and sputtering capability of the fevored construction material. The FPD-III end-cell design causes the plasma area to increase at a very slow rate, which, if no other steps were taken, would result in the direct converter being placed at a considerable distance from the end mirror coil. One method of increasing the plasma-area rate of change is to add bucking coils after the end mirror coil (Fig. 3-31). We made the choice of a suitable bucking coil configuration by trial and error; we did not attempt to optimize the magnet design. Figure 3-32 showg the geometry of the bucking coil in relation to the elements of the direct converter.

\section{Design Descziption}

The electron collectors were designed as two elements: an outer collector and an inner collector. The inner collector is a flat plate normal 
Table 3-8. Design requirements.

\begin{tabular}{lrr}
\hline & \multicolumn{2}{c}{$\begin{array}{c}\text { Power to be absorbed } \\
(\mathrm{MW})\end{array}$} \\
\cline { 2 - 3 } & Thermat & Electrical \\
& & \\
\hline & 6.54 & 14.2 \\
Inner sollector & 1.64 & 0.0 \\
Outer collector & 2.41 & 0.0 \\
Halo scraper & 5.72 & 0.0 \\
Halo dump & 16.31 & 14.2 \\
\multicolumn{1}{c}{ Total } & & \\
\hline
\end{tabular}




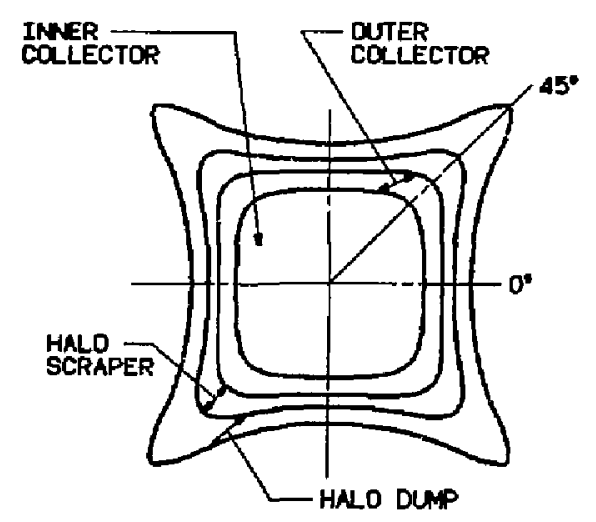

Fig. 3-30. Plasma cross section at $z=30 \mathrm{ml}$

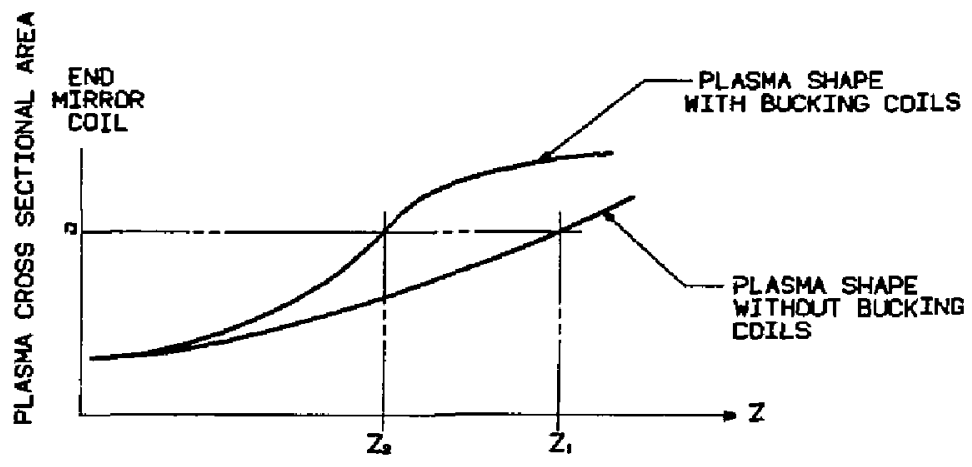

O=PLASMA CROSS SECTIONAL AREA REOUIRED FOR A GIVEN MATERIAL. $2\left(Z_{1}-Z_{2}\right)=$ REDUCTION OF MACHINE LENGTH BY USING BUCKING COILS. THE FLARE OF THE PLASMA CAN BE CHANGED BY INTRODUCING ORE OR MDRE BLCKING COILS. IN THE FPE-3 DESIGN YNE SHDN THD BLCKING COILS.

Fig. 3-31. The effect of adding bucking coils on plasme shape. 


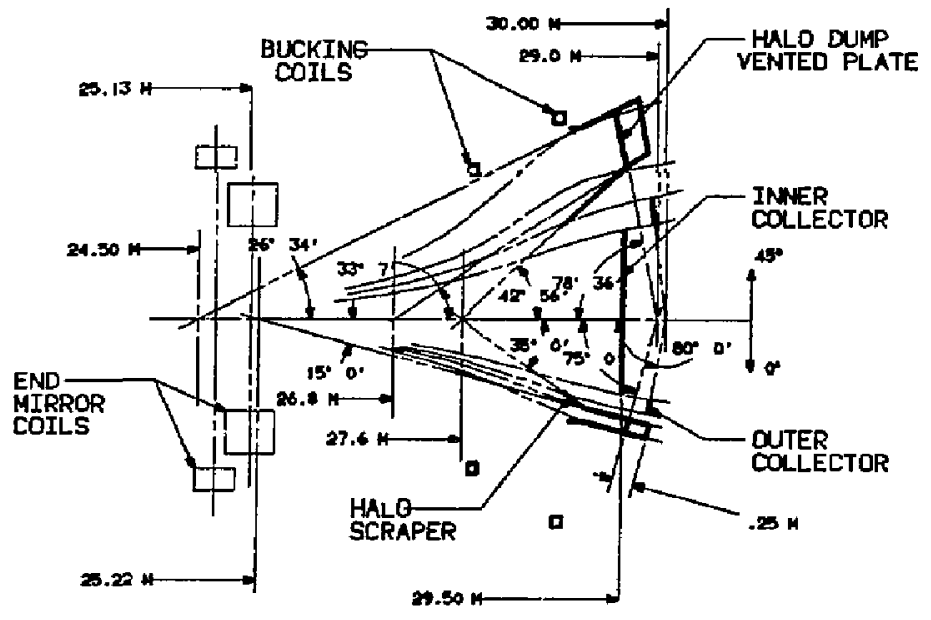

SECTION THROUG: PLASMA MND CONVERTER ELEMENTS AT $0^{*}$ AND 45*

Fig. 3-32. Direct converter geometry. 
to the plasme on the axial centerline of the machine. The outer edge conforms to the magnetic field surface containing the inner collector flux that satisfies the correct fusion power and average pressure in the central cell. The outer collector is made of four flat segments tilted so that the particle impingement at the center of each plate is normal. The edges of the outer collector are masked by the inner collector over the inner edgeg and by the halo scraper over the outer edges.

The halo-scraper plates are flat plates configured as the surfaces of a pyramid. There are eight segments, where the four larger segments form the surface of the pyramid and the fcur smaller begments are formed as "chamfers" to the edge of the pyramid. The angle of the scraper plates is determined by the ratio of the heat flux allowed by the chosen construction material to the heat flux normal to the plasma. The surfaces described as chamfers were added to keep the enclosing diametral size to a minimum. The inner edge of the halo scraper is at ground potential. The halo-dump surface is also flat and follows the geomerry of and is connected to the halo scraper. The dump surface is normal to the plasma at the center of each plate. The halo-dump surface is vented ( $5 \%$ of its area) to allow the scrape-off plasma to flow into a plenum (behind the vented plate) and be pumped by the reactor vacuum system. Figures $3-33,3-34$, and $3-35$ show the design of this direct converter and its support structure.

To simplify installation, removal, and to ease any remote manipulation that might be required, the direct converter is attached to a cover plug of the end-cell vacuum vessel and can be vertically crane hoisted. If repair of any part of the direct converter is required during the lifetime of the reactor, the complete assembly is removed to a hot cell for repaits.

Figure $3-36$ is an end view of the plasma footprint on the direct converter elements. Ta the right of the centerline is a half view of the inner and outer collector. To the left of the centerline is a half view of the halo scraper and halo dump. In FPD, the direct converter elements were designed using the true plasma shape as it varied with the azimuthal angle. The shape is determined from a Eclution of the EFFr magnetic-field code with plasma corrections on the Layrence Livermore National Laboratory Cray computer. After the plasma shape is confirmed, the EFFI output is then used 


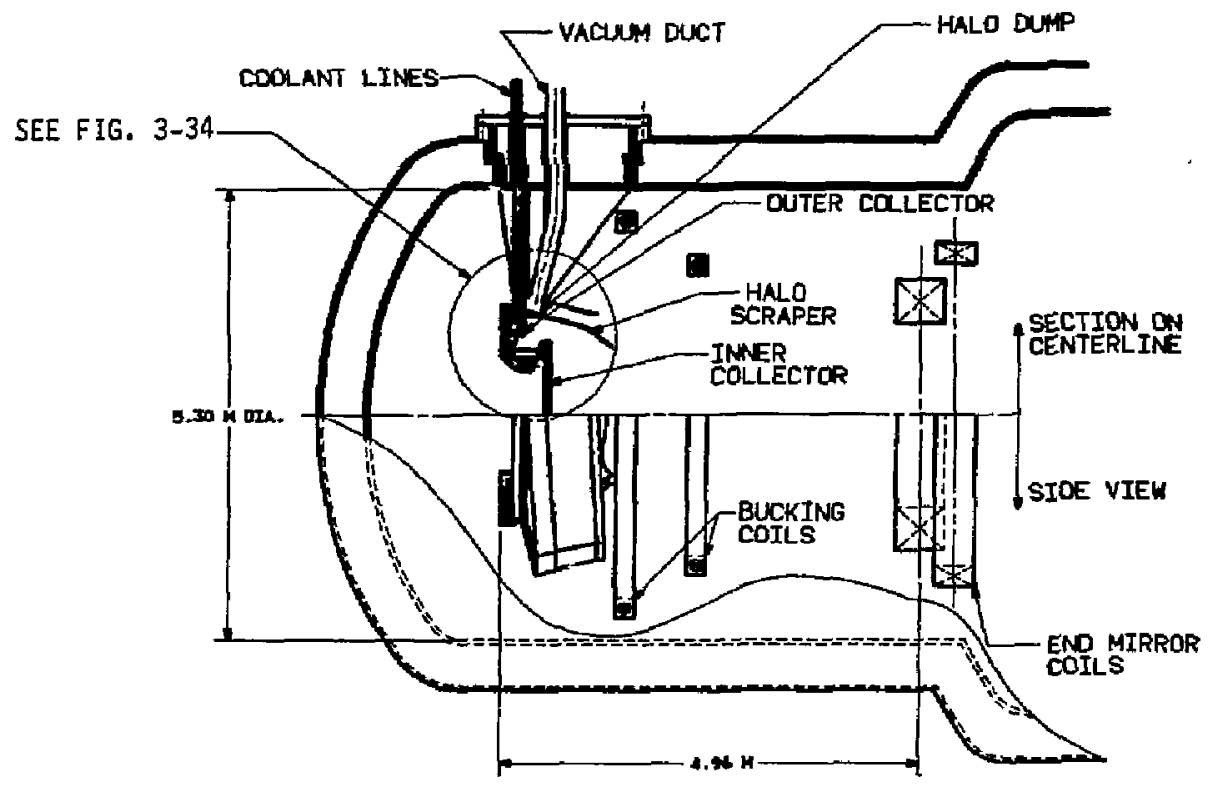

Fig. 3-33. Direct converter design. 


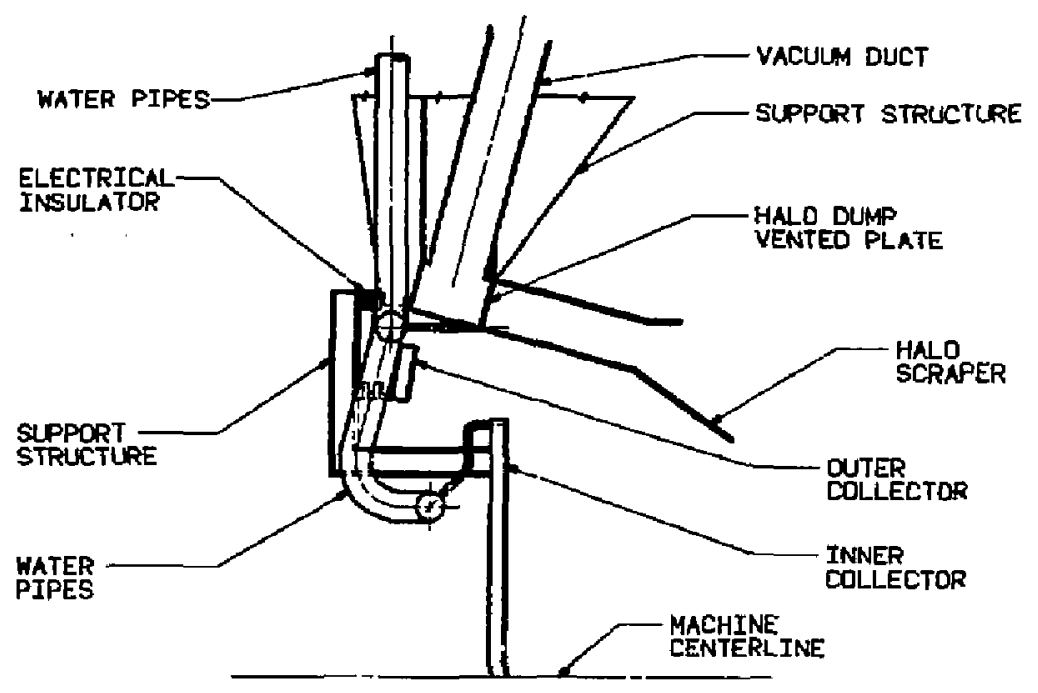

Fig. 3-34. Direct converter design (enlarged portion of Fig. 3-33). 


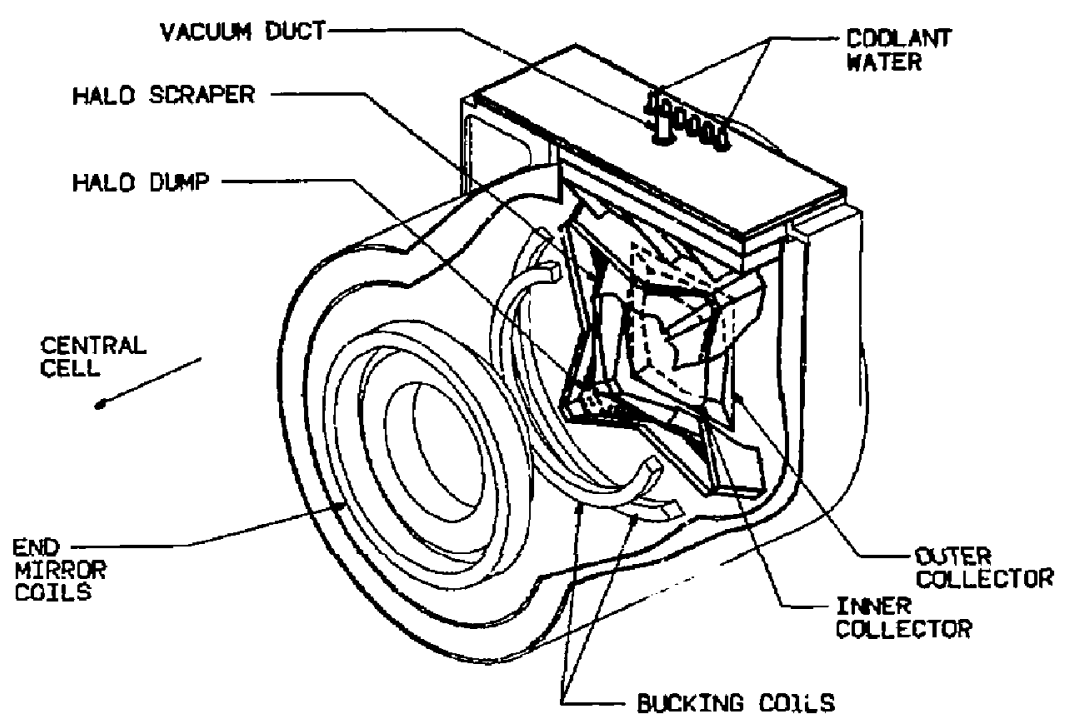

Fig. 3-35. Direct converter.

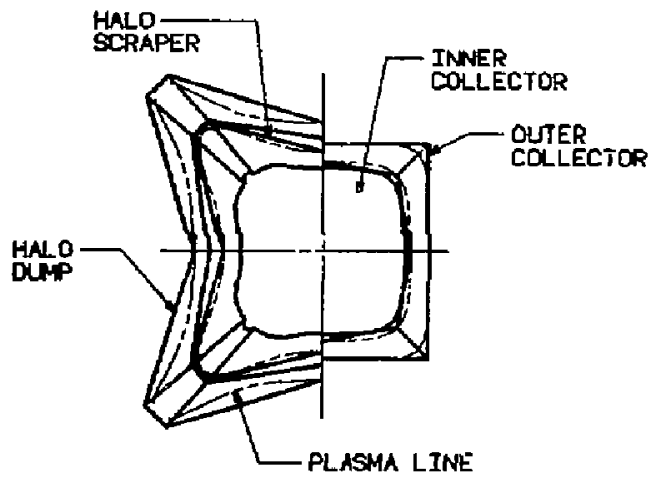

Fig. 3-36. Direct-converter element shape shows plasma fontprint on each element. 
to define the plasm geometry in the Gruman CADAM system. The CADAM oystem is then used to perform design studies to select the mot satisfactory converter-elemeat shapes and planes. This process represents a significant improvement over the approach previously used on the MARS design, ${ }^{1}$ where an apprcximate axisymmetric plasma shape was used.

\section{$\underline{\text { MateriaIs }}$}

The results from our materials selection study for the direct-converter components are shown in Table 3-9. The FPD device is an experimental reactor and is designed for 5 full power years (FPY) of operation. For FPD, the direct-converter thermal power is diacarded; therefore, the coolant temperatures and, consequently, the pressures are lower than in a power reactor where the dires: converter thermal power is used. It is possible then, to use less exotic and, therefore, cheaper materials for the direct-converter elements. Table 3-9 shows the six materials that were considered in the design, only the yield stresses at oferating temperature are given in the table. Zirconium copper ( $\mathrm{rCu}$ ), the nolybdenum alloy (TZM), and the vanadium-15 chrome-5 titanium alloy (V15Cr5Ti) satisfy both yield-stress and boiler-code-stress requirements. Inconel (INC0718) satisfies yield, but not boiler code conditions. The 316 stainless steel satisfies neither yield-stress nor boiler-code-stress conditions; HT- 9 Ferritic steel marginally satisfies the yield-stress conditions. Because of its lower cost, we decided to use the ZrCu material.

\section{Thermal vonditions}

Tables 3-10 and 3-11 show the inner and outer collector performance and reference design. The tatal conling-water pumping power to the collectors and the halo scraper and dump is $27 \mathrm{kt}$. All elements have a common system pressure of $0.65 \mathrm{MPa}$. On the inne: collector all channels are in paralle1. The design driver for the coolant water pressure drop is the coolat channel path with the highest heat load. The coolant water pressure drop is determined by the Fanning relationship. 5 presaure reducing valves are 
Table 3-9. Material study.

\begin{tabular}{lccc}
\hline Material & $\begin{array}{c}\text { Maximum front } \\
\text { surface temperature } \\
\left({ }^{\circ} \mathrm{C}\right)\end{array}$ & $\begin{array}{c}\text { Combined thermal } \\
\text { and pressure stress } \\
\text { (MPa) }\end{array}$ & $\begin{array}{l}\text { Yield } \\
\text { stress } \\
\text { (MPa) }\end{array}$ \\
\hline T2M & 133 & 46 & 896 \\
$316 S S$ & 406 & 619 & 117 \\
HT-9 & 291 & 356 & 386 \\
ZrCu & 101 & 31 & 220 \\
V15Cr5Ti & 237 & 130 & 580 \\
INC0718 & 342 & 480 & 910
\end{tabular}

Reference conditions

Coolant velocity $(\mathrm{m} / \mathrm{s}) \quad 5.7$

Coolant in/out temperatrue $\left({ }^{\circ} \mathrm{C}\right) \quad 30 / 80$

Front wall thickness (cm) 0.3

Channel width/depth (cm) $\quad 0.6 / 0.4$

Average heating rate $\left(\mathrm{HW} / \mathrm{m}^{2}\right) \quad 0.82$

Heating rate peaking factor 2.07

Conclusion--ZrCu chosen based on cost 
Table 3-10. Inner and outer collector performanc.

\begin{tabular}{|c|c|c|}
\hline & $\begin{array}{c}\text { Innex } \\
\text { collector }\end{array}$ & $\begin{array}{l}\text { Outer } \\
\text { collector }\end{array}$ \\
\hline Thermal power (each end) (MW) & 3.27 & 0.82 \\
\hline Area $\left(\mathrm{m}^{2}\right)$ & 2.76 & \\
\hline \multicolumn{3}{|l|}{ Flux } \\
\hline Average $\left(\mathrm{MW} / \mathrm{m}^{2}\right)$ & 1.19 & \\
\hline Design $\left(M W / \mathrm{m}^{2}\right)$ & 1.74 & 1.45 \\
\hline \multicolumn{3}{|l|}{ Temperature } \\
\hline Coolant in/out $\left({ }^{\circ} \mathrm{C}\right)$ & $30 / 80$ & $30 / 80$ \\
\hline Maximum service $\left({ }^{\circ} \mathrm{C}\right)$ & 150 & 187 \\
\hline \multicolumn{3}{|l|}{ Stress } \\
\hline Maximum combined (MP) & 102 & 85.1 \\
\hline Yield $(\mathfrak{M P a})$ & $205\left(\right.$ at $\left.150^{\circ} \mathrm{C}\right)$ & $196\left(\right.$ at $\left.187^{\lrcorner} \mathrm{C}\right)$ \\
\hline \multicolumn{3}{|l|}{ Coolant } \\
\hline Elow rate $\left(\mathrm{m}^{3} / \mathrm{s}\right)$ & 0.0156 & 0.0039 \\
\hline Velocity $(\mathrm{m} / \mathrm{s})$ & 4.3 & 2.9 \\
\hline Pressure $(\mathrm{MPa})$ & 0.65 & 0.65 \\
\hline Pumping power (kW) & 2.9 & 0.4 \\
\hline
\end{tabular}


Iable 3-12. Inner and outer ccllector design.

\begin{tabular}{|c|c|c|}
\hline & $\begin{array}{l}\text { Inner } \\
\text { collector }\end{array}$ & $\begin{array}{l}\text { Outer } \\
\text { collector }\end{array}$ \\
\hline Configuration & \multicolumn{2}{|c|}{$\begin{array}{l}\text { Zirconium copper with fully } \\
\text { caoled back wall }\end{array}$} \\
\hline Coolant & Water & Water \\
\hline \multicolumn{3}{|l|}{ Coolant channel } \\
\hline Width (cm) & 0.7 & 0.7 \\
\hline Depth $(\mathrm{cm})$ & 0.3 & 0.3 \\
\hline Channel wall thickness $(\mathrm{cm})$ & 0.3 & 0.3 to 0.9 \\
\hline Front wall thickness (cm) & 1.0 & 1.0 \\
\hline Channe1 ar:angenent: & $\begin{array}{l}\text { In parallel } \\
\text { with header }\end{array}$ & Radial \\
\hline Channels per secter & 57 & 144 \\
\hline \multirow[t]{2}{*}{ Channels per chaunel path } & & 9 \\
\hline & & $\begin{array}{l}9 \text { channels in } \\
\text { series }\end{array}$ \\
\hline Sector leng.: $(\mathrm{cm})$ & 175 & \\
\hline Sector width $(\mathrm{cm})$ & 57 & \\
\hline Number of sectori & 3 & 4 \\
\hline Channel patihs fer sector & & 15 \\
\hline In/out header pipe size $(\mathrm{cm})$ & 10 & 5.0 \\
\hline Sector header pipe size $(\mathrm{cm})$ & 6.4 & 5.0 \\
\hline
\end{tabular}





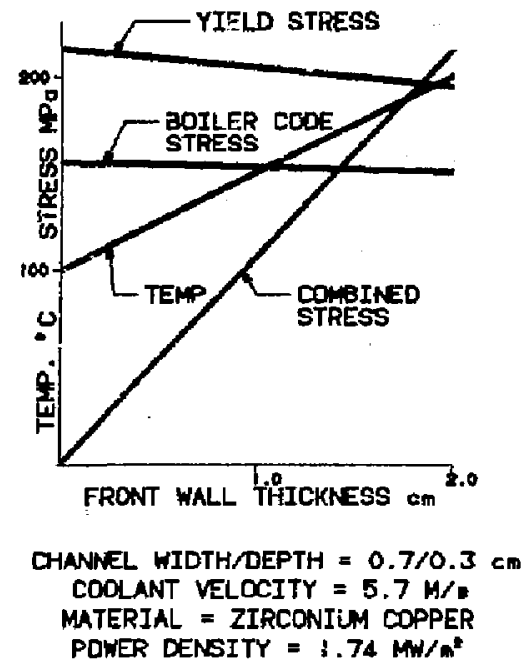

Fig. 3-37. Inner-collector system study.

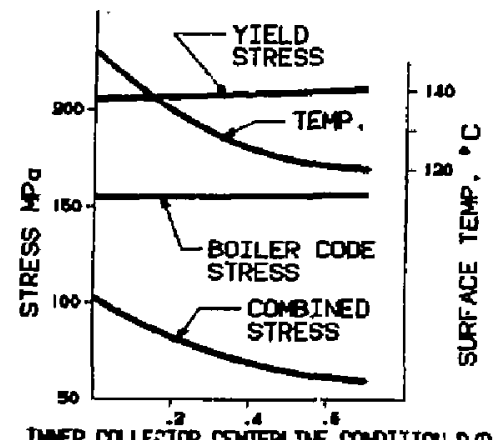

SINGLE ENDED POWER=3.27 MN FRDNT PLATE THICKNESS $=1.0 \mathrm{~cm}$ MATERIAL $=$ ZIRCONILA COPPER

CHAWEL HIDTH/DEPTH=0.7/0.3 c.

INER COLECIOR CDVIERLDE CONDITIOR DAR.

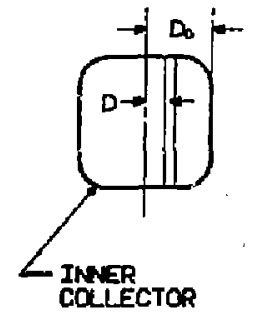

Fig. 3-38. Variation of stress and temperature on the innex collector. 
Table 3-12, Halo acreper and halo dump performance.

\begin{tabular}{|c|c|c|}
\hline Power (each end) (MH) & \multicolumn{2}{|c|}{4.06} \\
\hline Coolant & \multicolumn{2}{|c|}{ Hater } \\
\hline Temperature (inlet/outlet) $\left({ }^{\circ} \mathrm{C}\right.$ ) & \multicolumn{2}{|c|}{$30 / 80$} \\
\hline Flow race $\left(\mathrm{m}^{3} / \mathrm{s}\right)$ & \multicolumn{2}{|c|}{0.0194} \\
\hline Pressure (MPa) & \multicolumn{2}{|c|}{0.65} \\
\hline Pumping power (kw) & \multicolumn{2}{|c|}{14.0} \\
\hline Goolant velocity $(\mathrm{m} / \mathrm{s})$ & \multicolumn{2}{|c|}{6.8} \\
\hline & $\begin{array}{c}\text { Halo } \\
\text { Ecraper }\end{array}$ & $\begin{array}{l}\text { Halo } \\
\text { dump }\end{array}$ \\
\hline Flux (design) $\left(\mathrm{MW} / \mathrm{m}^{2}\right)$ & 1.01 & 1.15 \\
\hline Surface temperature (plasma side) $\left({ }^{\circ} \mathrm{C}\right)$ & 159.0 & 145.0 \\
\hline Stress--maximum combined (MPa) & 119.0 & $80 .-$ \\
\hline Material yie1d strength (MPa) & 203.0 & 205.0 \\
\hline
\end{tabular}


Table 3-13. Halo scraper and halo dump deaign.

\begin{tabular}{|c|c|}
\hline Number of sectors & 4 \\
\hline Configuration & $\begin{array}{l}\text { Flat plate sections with } \\
\text { a side and chamfer part }\end{array}$ \\
\hline Material & airconium copper \\
\hline Coolant channel & \\
\hline Width (cm) & 0.7 \\
\hline Depth (cm) & 0.3 \\
\hline Hrader pipe size $(\mathrm{cm})$ & 10.0 \\
\hline Subheader pipe size $(\mathrm{cm})$ & 6.4 \\
\hline \multicolumn{2}{|l|}{ Channels per sector } \\
\hline Side part & 124 \\
\hline Chamfer part & 12 \\
\hline Channel configuration & $\begin{array}{l}\text { Coolant flows in series } \\
\text { through the scraper and dump }\end{array}$ \\
\hline $\begin{array}{l}\text { Channels per channel path } \\
\text { Halo scraper }\end{array}$ & 4 \\
\hline \multicolumn{2}{|l|}{ Channel wall thickness } \\
\hline Side part $(c \Phi)$ & 0.3 to 1.25 \\
\hline Chamfer part $(\mathrm{cm})$ & 0.45 to 1.22 \\
\hline $\begin{array}{l}\text { Front wall thickness (cm) } \\
\text { Halo dugp }\end{array}$ & 2.0 \\
\hline \multicolumn{2}{|l|}{ Channel wall thickness } \\
\hline Side part $(\mathrm{cm})$ & 0.7 to 2.1 \\
\hline Chamfer part $(\mathrm{cm})$ & 1.2 to 1.9 \\
\hline $\begin{array}{l}\text { Front wall thickness }(\mathrm{cm}) \\
\text { Vent arrangement }\end{array}$ & 1.2 \\
\hline Vent area & $5 \%$ of vented plate \\
\hline Vent configuration & $\begin{array}{l}\text { Centered in every other } \\
\text { channel wall }\end{array}$ \\
\hline Azimuthal spacing (cm) & 2.7 to 5.6 \\
\hline Radial spacing $(\mathrm{cm})$ & 3.0 to 6.3 \\
\hline Vent pipe o.d., i.d. ( & $1.35,1.0$ \\
\hline
\end{tabular}


consists of aide part and chamfer part. The coolent channels are milled radially in the acraper and dump elements and are of uniform width and depth. The channel wall thicknes varies for a minimum value at the inner edge to a maximum value at the outermost edge. The minimum and maximum values are given for the side and chamfer parts of the scraper and dump in Table 3-13.

The halo dump is vented such that the scrape-off plasma can flow into a plenum chamber behind the vented piate and then be pumped away by the reactor vacuum system. The vented area is $5 \%$ of the total verited plate area. Vents are located and centered in every other channel wall as shown in Fig. 3-39. The vent diameter is $1.0 \mathrm{~cm}$. The vent azimathal and radial spacing varies over the faces of the vented plate so as to maintain the $5 \%$ vented area. Minimum azimuthal distances are at the inner edge of the vented plate and the maximum at the outer edge. Radial spacing distances are maximum at the inner and minimum at the outer edges. Minimum and maximum dimensions are given in Table 3-13.

Figure 3-40 shows the maximum yield and combined stresses, in addition to the temperature and heeting at any azimuthal angle of the halo scraper. The temperature and combined stress, for example, vary from a maximum value at the center of the side part of the scraper (0-deg azimuthal angle) to a minimum at a corner. The discontinuity in the curves at an angle of $41.4 \mathrm{deg}$ occurs at the junction of the side and chamfer parts of the scraper. The calculation of these values for FPD represents a significant improvement over our previous analysis of MARS $^{1}$ (i.e., these values would be constant with azimuthal angle using the MARS analygis).

\section{Sputtering}

We analyzed the sputtering loss of the halo scrafir because the scraper is the element that receives most of the ion flix; consequently, most of the aputtering loss in the direct converter will take place there. Very little net sputtering will take place on the vented plate because the sputtered scraper material will probably redeposit on the plate. A calculation of the bcraper sputtering loss using the DSPUT equations ${ }^{7}$ shows that a maximum of $0.7 \mathrm{~cm}$ of meterial will de last in 5 FPY of reactor operation. This 


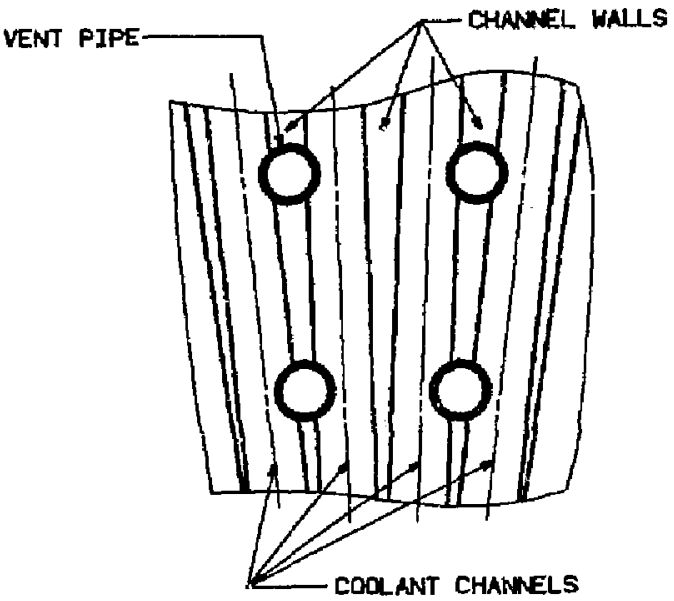

Fig. 3-39. Halo-dump vented-plate configuration.

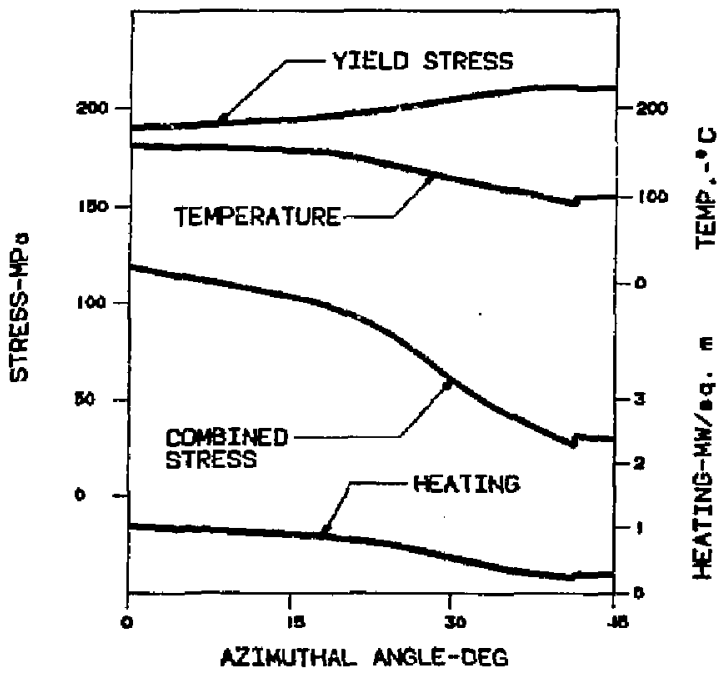

Fig. 3-40. The variation of yield stress, temperature, and heating with azimuthal angle in the halo scraper. 
calculation was made for a particle density of $1.3 \times 10^{16}$ particles $/ \mathrm{cm}^{2}$. a at 30-keV energy. Comparison of DSPUT with a TRIM code analysis for deuterium on copper at energies tatween $200 \mathrm{eV}$ and $1 \mathrm{keV}$ (Ref. 8) shows that DSPUT agrees with the TRIM code within a factor of two in that energy range. The $0.7-\mathrm{cm}$ loss is probably correct within a factor of two. The halo-screper front-plate thickness is $2.0 \mathrm{~cm}$ and could be increased at least $50 \%$ without introducing unmanageable thermal stresses. Thus, the scraper should be able to withstand a 5-FPY sputtering 10ss. The frontwa1l thickness for the outer elements should be able to withstand any small sputtering loss there.

\section{Coolant-Water Erosive-Wear Mechanism}

There are three possible mechanisms that could cause mechanical erosicn of cookent piping and equipment by the flowing cuolant: liquid-droplet impingement, aingle-phase flow, and cavitation. ${ }^{9}$ Liquid-droplet impingement is not a viatin exosion mechar:ism in the direct-converter coolant system because the coolant is never in the condensing vapor form.

Single-phase erosion occurs in three forma: ourface shear stress, nomal stress, and nonstaedy liquic flow (water hamer). Calculations show that the imposed shear and nurmal stresses ${ }^{9}$ are many orders of magnitude lower than the $\mathrm{ZuCu}$ shear- and tensile-creep rupture stress at evaporated temperature. The shear-creep rupture stress is taken as one half the cenuile value. These calculations were made for velocities at least an order of magnitude higher then typical direct-converter coolant velocities. Water hamer could cause a problem. However, hammer damage is structural rather than erosive, and the coolant flow system can be configured and operated to avoíd it.

Cavitation on copper and its alloys can be very destructive. Studies at the Vibratory Cavitation Facility at the University of Michigan show that the maxinum mean depth of penetration rate, which is the material-volume loss rate per exposed area for BS1433 copper, can be $s i x$ times that of nickel 270 and 15 to 20 times that of stainless ateel. 10 
A measure of cavitation initiation is the parameter 5 defined on Fig. 3-41. If the parameter $S$ for a particular flow syotem ig greater than a parameter Sc, determined for a particular flow conponent like a valve or an elbow, then no cavitation will take place at that particular flow component. Recommended values of Sc for various piping components in common soe in the electric power industry are given in Ref. 11. Examinations of the directconverter halo scraper and the inner- and cuter-collector coolant channels and piping configuration show that an equivalent component with the maximum $S e$ is the short-radius elbow $(\mathrm{Sc}=30$ ). In the halo dump, flow around the vented pipes is equivalent to flow through a conventional glove valve ( $\mathrm{Sc}=21.0$ ). Table 3-14 shows the required system-pressure increase needed to prevent cavitation for the flow element velocities given. The pressure increase in the halo dump systant is the design driver. For FPD, if the system pressure is increased 4 atm above the design driver to prevent liquid vaporization anywhere in tine coolant system, then cavitation will not take place.

\section{Radiolytic Corrosion}

The action of ionizing radiation can significantly alter the composition of water employed as a direct-converter-element coolant. A relatively small quantity of oxygen or pexonide resulting from radiolysis can have unfavorable effects on cortosion processes for copper elements.

During energy absorption, both ionizing and reducing radicals are formed in the coslant water. ${ }^{12}$ The radicals are not uniformly distributed throughout the water, but are formed in regions of local concentrations or "spurs" resulting fron the energy absorption process. Each individual spur is quite small [10 to 15 angetrom uaits $(A)$ in radius] and contain about six radicals. The oxidizing radical is primarily oH and the reducing radical is the hydrogen atom. The distance between these spurs is determined by the linear energy transfer of the radiation (LET, $e V$ per $A$ ). If the reducing and oxidizing radicals are spatially separated and exiat at high concentrations, then the corrosive reactions can take place. If the radicals are more hornogeneously diatributed, they will recombine and the corrosive reactions will be curtailed. 


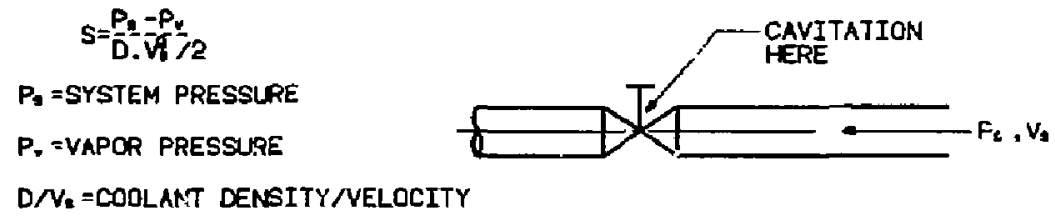

NO CAVITATION FOR $S>S_{\varepsilon}$, WHERE $S_{\varepsilon}$ DEPENDS ON FLOW SYSTEM

Fig. 3-41. Cavitation number measure of cavitation initiation. 
Table 3-14. System presgure increase to prevent cavitation.

\begin{tabular}{lccc}
$\begin{array}{c}\text { Direct } \\
\text { converter } \\
\text { 2lement }\end{array}$ & $\begin{array}{c}\text { Velocity } \\
(\mathrm{m} / \mathrm{s})\end{array}$ & $\begin{array}{c}\text { Suggestad } \\
\mathrm{S}_{\mathrm{c}}\end{array}$ & $\begin{array}{c}\text { System pressure } \\
\text { increase } \\
\text { (atm) }\end{array}$ \\
\hline Halo dump & 6.0 & 21.0 & 3.7 \\
Halo scraper & 10.0 & 3.0 & 1.5 \\
Inner collector & 7.2 & 3.0 & 0.77 \\
Duter collector & 3.3 & 3.0 & 0.16 \\
& & & \\
Conclusion-cavitation can be avoided vith suitable \\
increase in system pressure
\end{tabular}


During the irradiation, intermediate reactions form moleculac species such as $\mathrm{H}_{2} \mathrm{O}_{2}, \mathrm{HO}_{2}$, and other $\mathrm{H}-\mathrm{O}$ molecules. ${ }^{12}$ It is the presence of these products, particularly $\mathrm{H}_{2} \mathrm{O}_{2}$ together with the $\mathrm{OH}$, that accelerates the corroaion (i.e., radiolytic corrosion) of the copper. ${ }^{13}$ Reaction kinetic calculation ${ }^{12,14}$ showe that the initial a dition of hydrogen will otrongly suppress the formtion of the $\mathrm{H}_{2} \mathrm{O}_{2}$ and $\mathrm{O}_{2}$ species and will, therefore, strongly suppress the radiolygis. This kinetic theory is in good accord with previously observed special cases of importance in reactor technology. Two experiments are reported ${ }^{22}$ that support the kinetic theory analysis. In one of the experiments, 15 the authors show that at a hydrogen concentration of $14 \mathrm{~cm}^{3}$ (STP) per kilogram of 0.15 mole fraction of boric-acid water solution, no disgociation is observed at the higheat energy absorption rates. The boronfiosion ceaction showld entance the radiolysis over that of the purn water in the direct converter. In the other experiment, ${ }^{16} 5 \mathrm{~cm}^{3}$ of hydrogen pex kilogram of 0.10 mole fraction of boric-asid water solution suppressed the radiolysis. Whyte ${ }^{17}$ suggests that the introduction of $30 \mathrm{~cm}^{3}$ (STP) of dissolved $\mathrm{H}_{2}$ per kilogram of ccolant water vill completely suppress the radiolytic corrosion of copper. A calculation using Fenry"s law shows that 2-atm pressure is required to dissolve that quantity $\mathrm{H}_{2}$ at the maximum coolant temperature of the FPD direct converter. The coolant aystem pressure is 6.5 atm in FPD. A calculation shows that the fire hazard of the hydrogen released from solution upon system depressurization is regligible. The FPD device contains $3.2 \mathrm{~m}^{3}$ of direct-conperter coolant.

\section{Coolant-Line Electrical Insulation}

In FPD the inner and outer coliectors are held at 179 and $89 \mathrm{kV}$, respectively, with reference to the grounded vacuum vessel. In addition to an electrical load, these elements accomodate a large thermal load and are cooled by water flowing through pipes that are grounded at the coolant yumping equipment outside the reactor. Shorting of these elements to ground is through three posible current patha: the ccolant-piping metal, the coolant within the piping, and the outaide-coolant header surface within the reactor vacuum 
vessel. Electrical insulation is accompliehed by inserting an insulating plig in the coolant line within the vacuum vessel and by maintaining a low coolantwater resistivity.

Deionizing and demineralizing coolant water systems have been tuilt at a number of research facilities. ${ }^{13}$ Flow rates vary from 30 to 46,000 gallons per minute and the coolant resigtivity is maintained to at least $1.0 \mathrm{k} / \mathrm{cm}$. The FPD deionizing facility falls within this flowrate range. Figure 3-42 is a study of the power loss through the coolant for the FPD inner collector. Results are reported in percent loss of the power collected. The collector potential is $179 \mathrm{kV}$ and the collected current is $207 \mathrm{~A}$. The study is for four irsert radii varying in length from 5 to $30 \mathrm{~cm}$. The coolant resistivity is $1 \mathrm{M}^{*} \mathrm{~cm}$ * The coolant conductor model is a cylinder of finite constant lengti between zero-resistant end masses. A correction iy made for the resistance at the junction. 19 The effect of this correction decreases as the cylinder length to diameter ratio increases. Figure 3-42 shows that for a $30-\mathrm{cm}^{-10 n g}$, 10-cm-diameter insert; $0.5 \%$ of the collected power is drained to ground at each insert.

Charge streaking across insulator surfaces is a major cause of high voltage vacuum failure in steady-state systems like a tandem mirror. The streaking can be greatly reduced by maintaining the potential drop across an insulator at $200 \mathrm{kV}$ and the average electric field parallel to the insulator surface at $10 \mathrm{kV} / \mathrm{cm}$ or less. ${ }^{20}$ To impede charge buildup, the insulating insert should be placed away from the neutron flux atreaming into the direct converter through the choke coil opening. A $30-\mathrm{cm}-$ long insert, required to limit power loss through the coolant, is more than enough to prevent electrical breakdown at the vacuum surface of the insulator. Table 3-15 lists the specifications of the coolant pipe insulating insert. The material, SP-1 polyimide ${ }^{21}$ can withstand the required coolant temperature and preasure environment. The material resistivity is greater than $10^{15} \Omega \cdot \mathrm{cm}$ and can be baked for outgassing. 


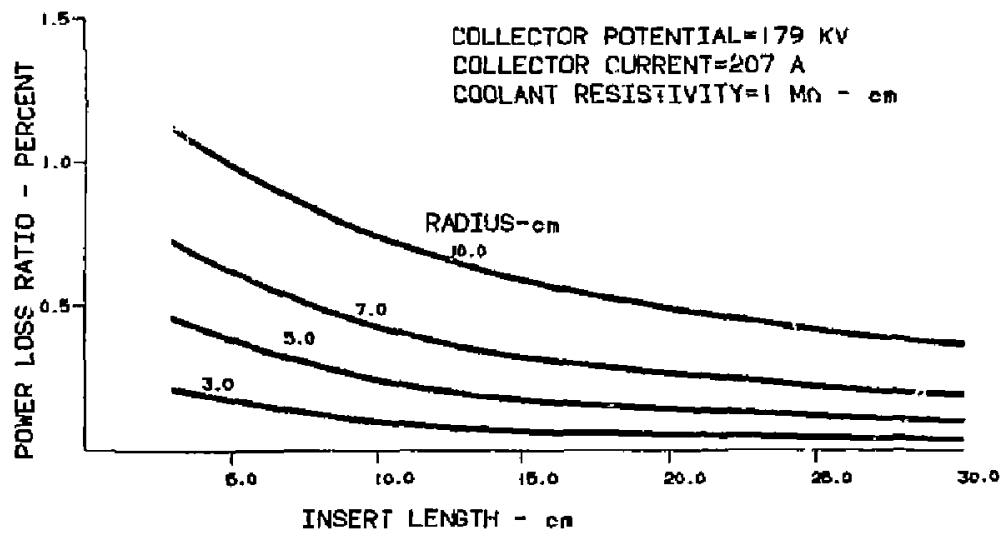

Fig. 3-42. Inner-collector power lcss through coolant. 
Table 3-15. Electrical insulation system degign for the coolant pipe insert.

$\begin{array}{ll}\text { Fotential } & \\ \text { Inner collector }(\mathrm{kV}) & 179 \\ \text { Outer collector }(\mathrm{kV}) & 89 \\ \text { Material } & \text { Glass reinforced polymide } \\ \text { Length (cm) } & 30 \\ \text { Diameter } & \\ \text { Inner collector }(\mathrm{cm}) & 10 \\ \text { Outer collector }(\mathrm{cm}) & 5 \\ \text { Wal I thickness }(\mathrm{cm}) & 1.5 \\ \text { Coolant pressure }(\mathrm{MPa}) & 0.65 \\ \text { Coolant temperature }\left({ }^{\circ} \mathrm{C}\right) & 80 \\ \text { Connectors } & \text { Flanged both end s } \\ \text { Coolant water } & \text { Dejonized to } 1 \mathrm{M} . \mathrm{cm} \text { regiativity }\end{array}$


Tritium Permeation and Inventory in the Direct-Converter Elements

The energetic impingement of tritium ions on the direct-converter Irfaces result in a steady-state tritium loss to the wall coolant as well as tratium inventory in the wall. To estimate the extent of these problems, a simple model of tritium diffusion and holdup, which takes into account the recombinative properties of the surface and the depth of the plasma implant, was applied to the direct converter surfaces. The model is based on the recommended approach of Baskes et $a 1,,^{22,23}$ which has been successfully employed by them in inveatigations of re-emission of implanted deuterium fxom stainless-steel walls, thermal absorption, and nuclear reactor profiling o $\vec{i}$ deuterium near surface concentrations.

Table 3-16 shows the single-ended tritium permeation ( $P$ in curies/day) and inventory in the direct converter componer. wa11g ( $I$ in curies) for all the converter elements. The tritium currents, particle energies, and frontand back-face temperatures are also given. Values art given for two wall materials, T2M and copper. The total permeation in curies per day for the copper and TZM is given at the bottom of the table. Current regulations allow water to be transported for processing and disposal at another site if the tritium concentration do 3 not exceed 0.1 curies/liter. ${ }^{24}$ For the permeation rates and the allowed concentration in the coolant water given above, it is practical to bleed off for disposal and make up with fresh coolant, 377 liters/day in the case of the copper components, and 135 literg/day in the case of the TZM. Therefore it is not necessary to build an expansive tritiated-water processing plant to process the direct-converter coolant water at the FPD experimental reactor site.

OCTOPOLE NLCLEONICS

This section sumnarizes our work to date in assessing the shielding aspects of the octopole end cell. We do not address the nucleonics of the central cell and choke coils here because they are virtually the same as those discussed in the FPD-I and II documentation. ${ }^{2}$ The radiation limits and the 1-D method of analysis used here to assess the FPD-III octopole coils are 
Table 3-16. Tritium permeation and inventory.

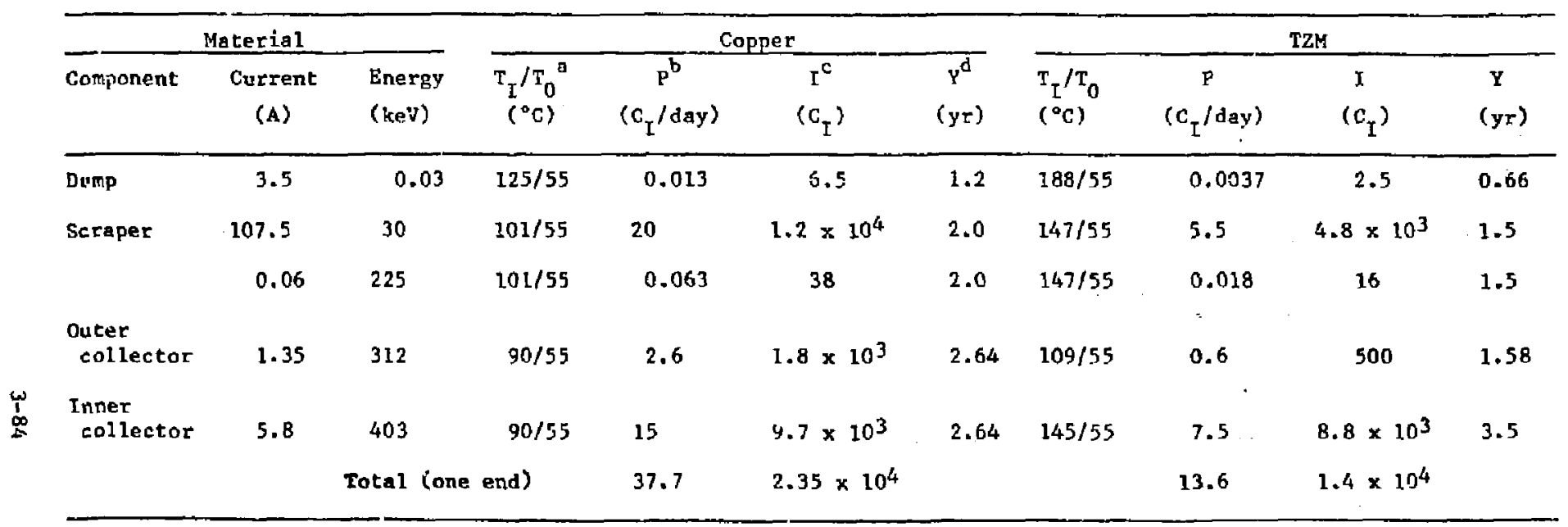

$a_{T_{I}}$ - Hot side temperature; $T_{0}=$ cold-side temperature

$b_{P}=$ Permeation

$c_{I}$ - Inventory

$d_{Y}$ = Years to attain steady-state inventory 
siwilar to those tued to auess the C-coils for FPD-II. Based on our initia: work, this FPD-III octopole end-cell configuration appears to provide sufficient space for shielding. This configuration should allow the small as well as the large octopole to be superconducting. We emphasize that this is a tentative conclusion. When time allows more rigorous and complete analysis to be done, we way find thet more shielding space is required in some locations. For example, we have not yet examined the affects of beamline and other required shield penetrations. The following sections summarize the radiation limits imposed, the method of analysis employed, and the application and results of this method when applied to the oftopole configuration.

\section{Radiation Limits}

In LLNL-FPD-84-016 (Ref. 2, Appendix), we originally set the maximum allowed rariation exposures in superconducting coils at the following 1 imits:

- $10^{11}$ rads in the insulation;

- $10^{18} \mathrm{n} / \mathrm{cm}^{2}\left(E_{n}>0.1 \mathrm{MeV}\right)$ in $\mathrm{NbTi}$, for a $20 \%$ drop in critical current, $70 \%$ of which is annealable at room temperature;

- $4 \times 10^{18} \mathrm{n} / \mathrm{cm}^{2}\left(E_{\mathrm{n}}>0.1 \mathrm{MeV}\right)$ in $\mathrm{Nb}_{3} \mathrm{Sn}$.

In LINL-FPD-84-48 (Ref. 2, Appendix), we later revised the fast ( $E ; 0.1 \mathrm{MeV}$ ) neutron fluence limits to allow for more design flexibility:

- $10^{20}$ to $10^{21} \mathrm{n} / \mathrm{cm}^{2}$ range for NbTi with an accompanying $25 \%$ lower critical current, using $10^{20} \mathrm{n} / \mathrm{cm}^{2}$ in this work;

- 1 to $4 \times 10^{19} \mathrm{n} / \mathrm{cm}^{2}$ range for $\mathrm{Nb}_{3} \mathrm{Sa}$ should be achievable, using $2 \times 10^{19} \mathrm{n} / \mathrm{cm}^{2}$ in this work. .

\section{Method of AnalygiB}

Because of the time and expense involved in doing detailed 3-D analysis of the end cell, we developed a $1-D$ method that we used to iterate the 
configutation in a timely manner. This 1-D method consists of the following steps :

1. Calculate heating and damage rates in superconducting coils vs shield thickness using $1-D$ slab geometry.

2. Galculace 14-HeV neutron-energy currents (wall loading) in 1-D cylindrical and spherical geometries using coil and plasma geometries and plasma source strengț.

3. Combine steps 1 and 2 to obtain a 1-D estimate of peak heating and damage rates.

4. Integrate the plasma neutron-1ine source (located under the octopole coils) as a function of $z$.

5. Corabine 1 and 4 to estimate total heating in the octopoles (our major assumption is that axial neutron transport is not significant).

In the first step, we calculate the heating and damage rates va shield thickress in 1-D slab geometry using the ONEDANT code and a 30-neutron plus 12-gamma xSLIB data 1ibrary based on ENDF/B- $V$. This code and its data library were developed at Los Alamos National Laboratory and were used by the University of Wisconsin for the MaRs project. 1

Figure 3-43 shows the configuration used to calculate radiation levels in the coil va shield thickness. The shield consists of a thick zone of $W(79 \mathrm{vol} \%)+\mathrm{H}_{2} \mathrm{O}(10 \mathrm{vol})+$ boric acid $(1$ volz $)+\mathrm{FE} 1422$ (10 volz) followed by a thin zone $(\sim 4 \mathrm{~cm})$ where TiH replaces the $W$. This shield reaults from a preliminary optimization study (see LLML-FPD-84-45, Ref. 2, Appendix). Figures 3-44 and 3-45 give the heating levels, neutron flux ( $E>0.1 \mathrm{MeV}$ ), and dose rates in the coil vs shield thickness at a wall loading of $1.0 \mathrm{~mW} / \mathrm{m}^{2}$. The total heatirg includes beth coil and case.

The octopole design differs from the c-coil design in that the space allowed between the shield and superconducting coil is $5 \mathrm{~cm}$ instead of $15 \mathrm{~cm}$, and the effective steel thickness in the case is $2 \mathrm{~cm}$ instead of $6 \mathrm{~cm}$. To account for this difference, we increased the local heating and damage rates by a factor of 2 over the rates calculated with the 1-D slab model. Total heating in the coil and case is unchanged from the c-coil design. 
$\mathbf{n}-$

6

8

FIRST WALL

( $\$ 0 \%$ STEEL. $20 \% \mathrm{H}_{2} \mathrm{O}$ )

8-

응

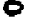

is

8

B.

항-

官-

8-

107

PLASMA

131

HALO

134 FIRST WALL

105 SHIELD

(79\% W/ TIH, Pb, $10 \% \mathrm{H}_{2} \mathrm{O}$

1\% BORIC ACID iO\%, FE 1422)

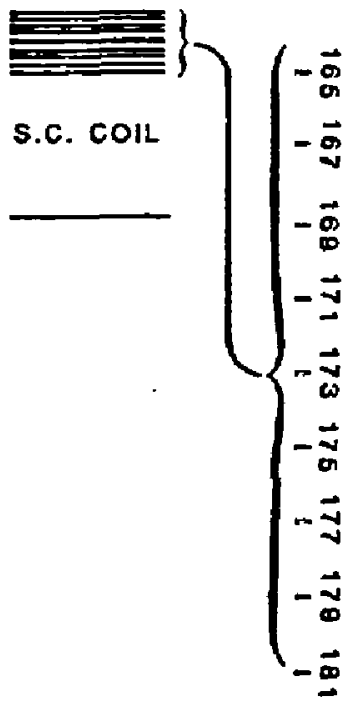

$1 6 5 \longdiv { \text { SS LAYER } }$

THERMAL INSUL.

(LOW DEN. AL.)

No

O'-

8

g-

$\left\{\begin{array}{r}\omega \\ -\vec{a} \\ -\vec{z} \\ -\vec{v} \\ -\overrightarrow{0} \\ -\overrightarrow{0}\end{array}\right.$

172.3

168.6 LN RAD SHELLD

COIL CASE

( $80 \%$ STEEL, $20 \%$ HE)

$175.3-$

176.3 POLYMMLEE

WindDING GASE

STEEL.

$178.3 \overline{\text { POLYIMIDE }}$

178.3

$180.3 \mathrm{~cm} \mathrm{S.C.} \mathrm{COIL}$

Fig. 3-43. The one-dimenaional slab model. 


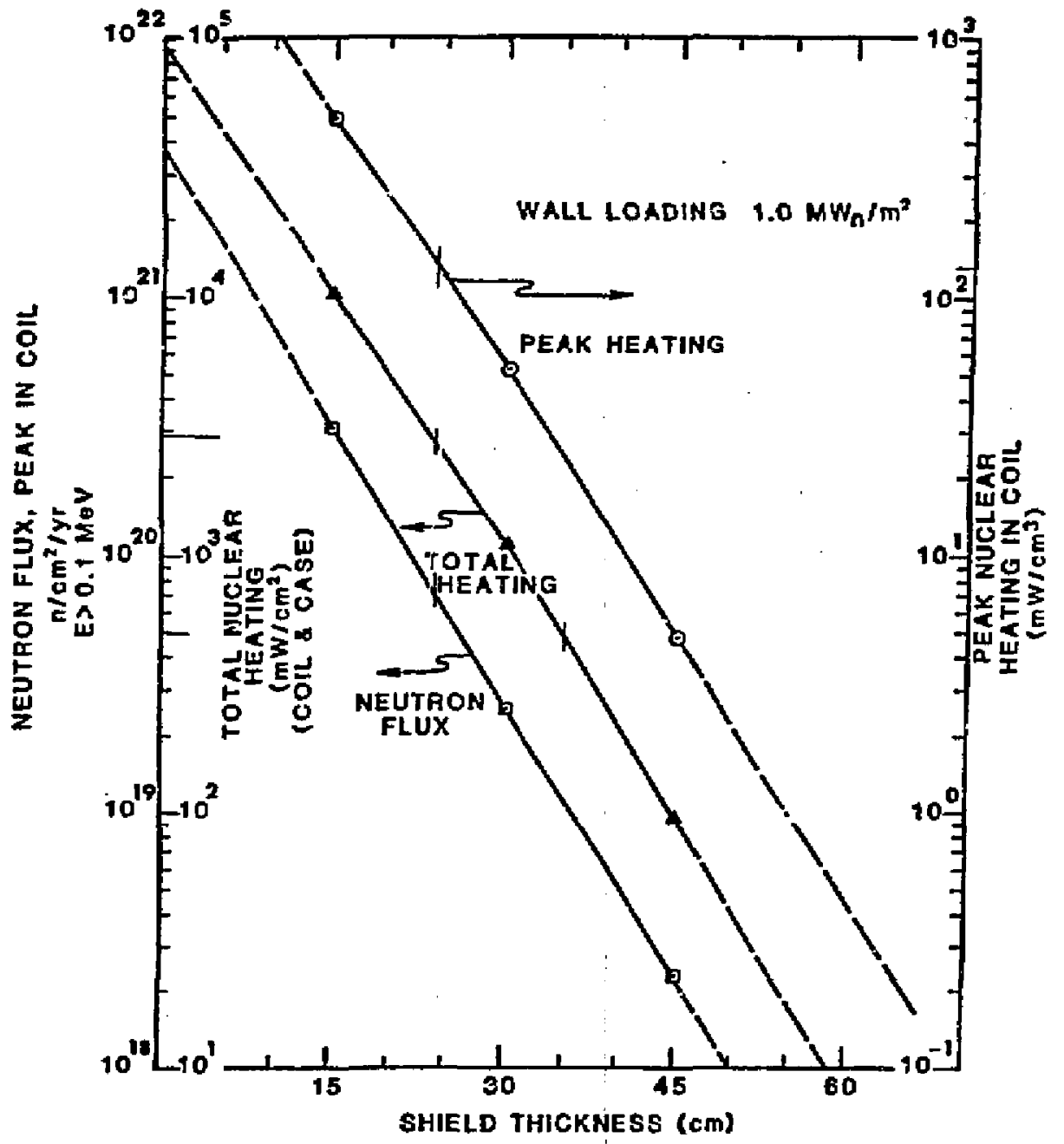

Fig. 3-44. Neutron flux and heating vs shieid thickness. 


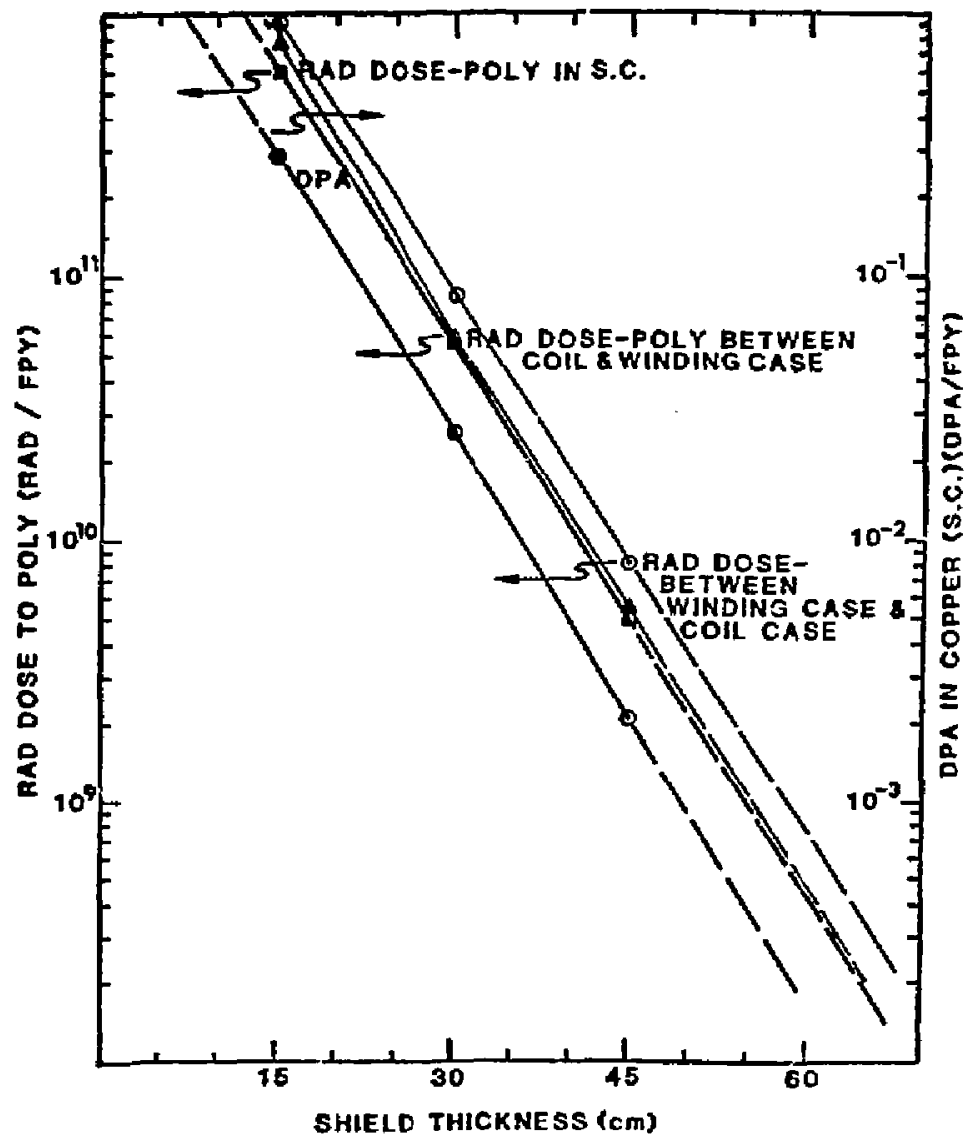

Fig. 3-45. Insulator dose rates and cu-dpa vo shield thickness. 
In the second step of the 1-D method, we examine end-cell coil geometries, plasma and neutron gources, and neutron source magnitudes to detemine 1-D wall loading at the coil where strength and geometry appear to combine with limited shield space to give significant heating and/or damage. rates. The final octopole end-ceil coil set for FPD-III (see Fig. 3-46) il lustrates this process. Figure 3-47 shows the $22.5^{\circ}$ cut through the vinding packs and the hot, halo, and tantel piasma boundaries as they thread through the end-cell coils. The fusion neutron-line-source strength in the octopole end cell is shown in Fig. 3-48. Examining Figs. 3-47 and 3-48 cogether, the geometry and source strength appear to combine to give three points where relatively high coil-radiation levels could occur. Starting at the small octopole (at $z \simeq 19.4 \mathrm{~m}$ ) and working outward, the first point is located in the small octopole coil at $\mathrm{z}=19.8 \mathrm{~m}$. At this point a local maximum in the line-source strength $\left(2.0 \times 10^{16} \mathrm{~g} / \mathrm{s}^{\circ} \mathrm{m}\right)$ and the 0.77 th bore of the small octupole combine to give a 1-D wa1l loading on the coil of $20.0094 \mathrm{mw} / \mathrm{m}^{2}$. The space between the coil and the halo plasma is $240 \mathrm{~cm}$. Subtracting $6 \mathrm{~cm}(2 \mathrm{~cm}$ for the case, $1 \mathrm{~cm}$ for the insulation, $2 \mathrm{~cm}$ for the gap, and $1 \mathrm{~cm}$ for the first wal1) leaves $34 \mathrm{~cm}$ for shielding. With $34 \mathrm{~cm}$ of shielding and a wall loading of $0.0094 \mathrm{MW} / \mathrm{m}^{2}$, Figs. 3-44 and 3-45 show that peak local heating and other radiation levels in the coil at this point are as follows:

- Peak heating $(\ddot{\mathrm{P}})=0.51 \mathrm{~mW} / \mathrm{cm}^{3}$,

- Peak flux $(\phi(E>0.1 \mathrm{MeV}))=2.4 \times 10^{17} \mathrm{n} / \mathrm{cm}^{2} / \mathrm{y}$,

- Peak rad dose to inculators $=5.6 \times 10^{8} \mathrm{rads} / \mathrm{y}$,

- Peak dpa in $\mathrm{Cu}=0.00023 / \mathrm{y}$.

The second point, where a local maxima in coil radiation levels may occur, is at the outer end of the inner bore of the amall octopole $(z \simeq 20.5 \mathrm{~m})$. At this corner, we assume that the coil radiation level results from the line source at $z=20.5 \mathrm{~m}$ and from an integral of the line source between $z=21 \mathrm{~m}$ and $z=24 \mathrm{~m}$. The latter accounts for the fact that the mantel intrudes into the space for shielding, and therefore limiting the minimum space on the end for shielding to $224 \mathrm{~cm}$. This minimum occurs in the $22.5^{\circ}$ plane (see Fig, 3-47). 


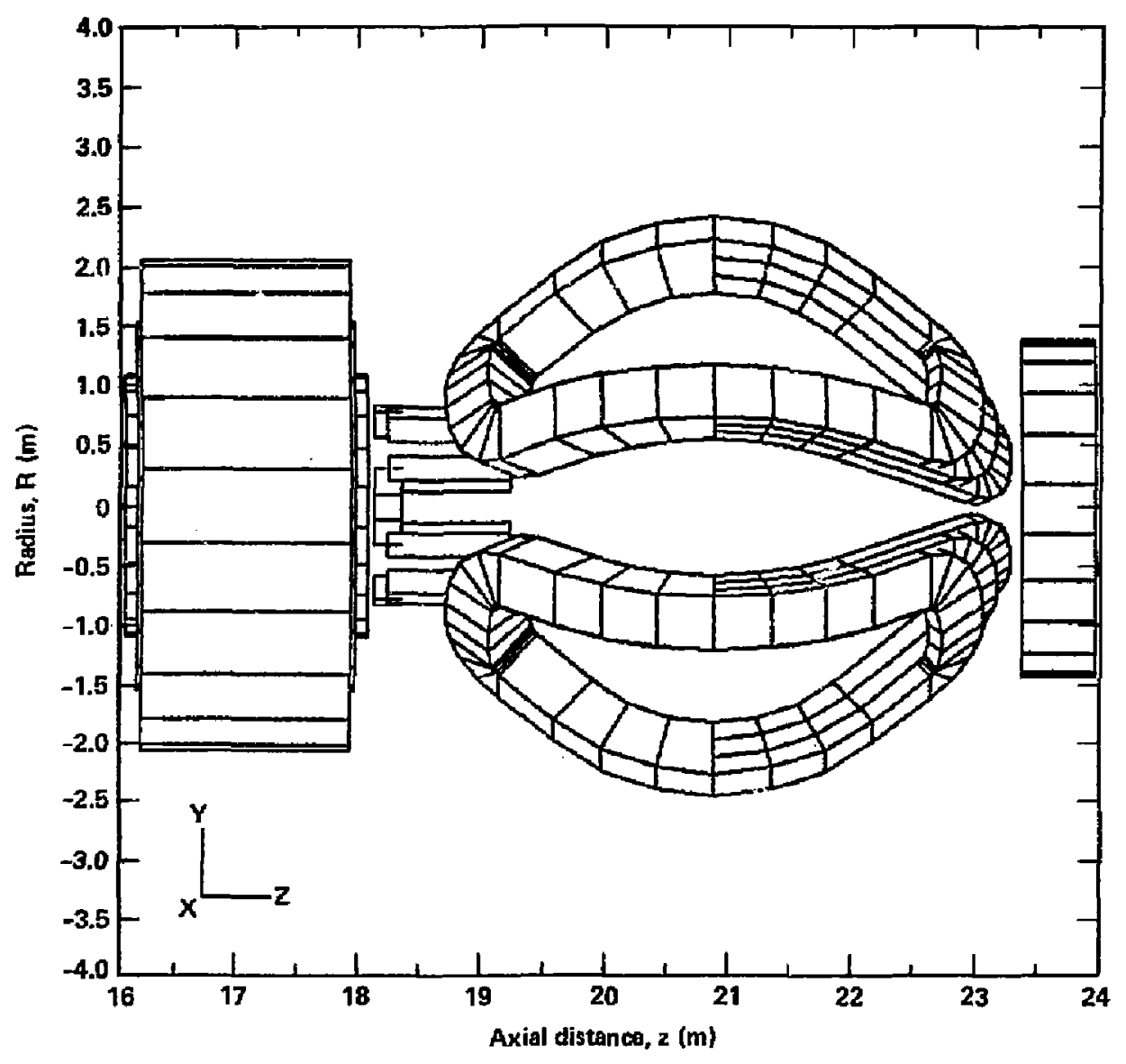

Fig. 3-46. End-cell-coil configuration. 


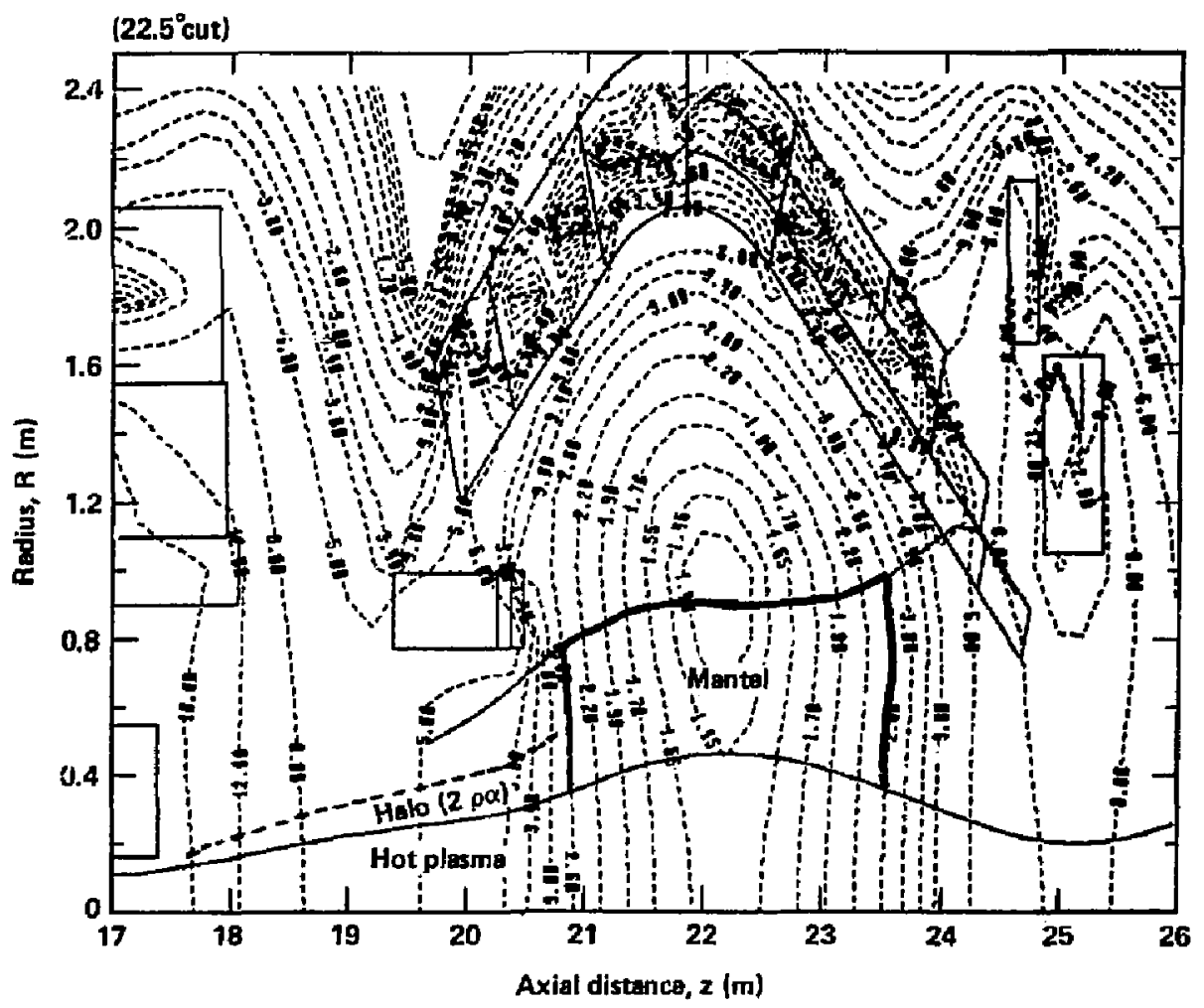

Pig. 3-47. End cell plasma, shield, and coil configuration. 


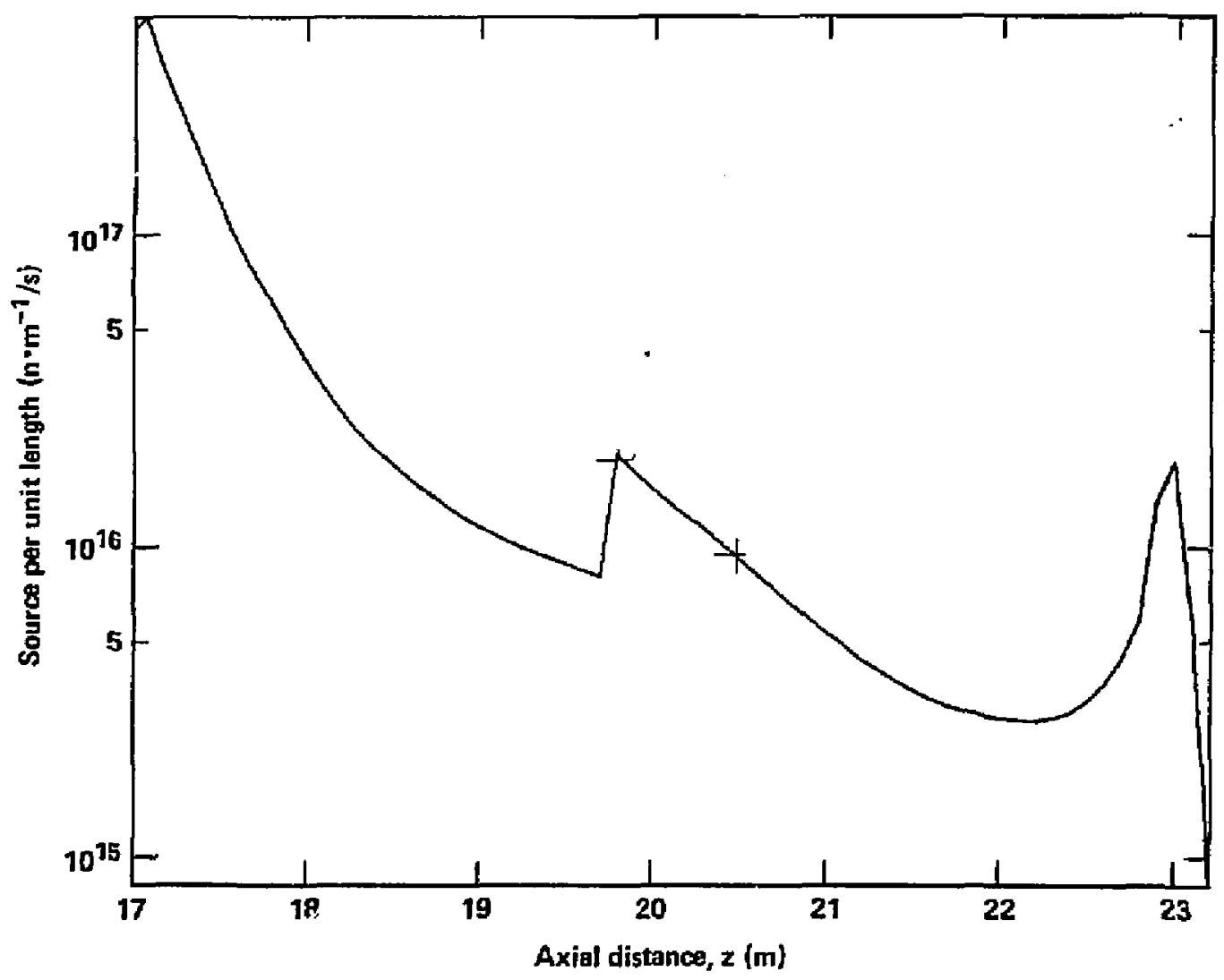

Fig. 3-48. Neutron (DT) line source in end cel1. 
The line source at $z=20.5 \mathrm{~m}$ is $1 \times 10^{16} \mathrm{n} / \mathrm{s}^{*} \mathrm{~m}$ and results in a wall loading on the coil of $0.0047 \mathrm{MW} / \mathrm{m}^{2}$ at $\mathrm{z}=20.5 \mathrm{~m}$. The integral of the 1 ine source between $z=21 \mathrm{~m}$ and $24 \mathrm{~m}$ (where $\mathrm{s}$ has dropped to 0 ) is $0.023 \mathrm{MW}$ (gee Fig. 3-49). Approximating this 0.023-MW line source by a 0.023-MF point source on the axis at $z=22 \mathrm{~m}$ results in a wall loading at the corner of the coil of $0.00062 \mathrm{MH} / \mathrm{m}^{2}$. The radial and axial space for shielding the inner corner of the coil at $z=20.5 \mathrm{~m}$ are both $24 \mathrm{~cm}$; thus, the combined hearing and damage rates at this point are

- Heating $=1.4 \mathrm{mw} / \mathrm{cm}^{3}$,

- $\phi \mathrm{n}(\mathrm{E}>0.1 \mathrm{MeV})=1.0 \times 10^{17} \mathrm{n} / \mathrm{cm}^{2} / \mathrm{y}$,

- Dose to insulator $=1.6 \times 10^{9} \mathrm{rads} / \mathrm{y}$,

- The dpa in $\mathrm{Cu}=0.00070 / \mathrm{y}$.

The third point or region, where a local maximum in the coil radiation levels should occur, is in the large octopole adjacent to the upper right-hand corner of the mantel (see Fig. 3-47), where apace for shielding drops to $235 \mathrm{~cm}$. This point is in view of the hot-plasma line source between $z=18$ to $23 \mathrm{~m}$. The integral of the line source between $z=18$ and $23 \mathrm{~m}$ is $5.1 \times 10^{16} \mathrm{n} / \mathrm{s}$, which gives $0.12 \mathrm{MW}$ of $14-\mathrm{MeV}$ neutrons. Concentrating this source on the axis at $z=22$ m results in a wall loading on the coil of $0.0018 \mathrm{~mW} / \mathrm{m}^{2}$. This wall loading, coupled with $35 \mathrm{~cm}$ of shielding, results in peak heating and damege rates that are about 20 times less than the peak found in the small octopole. In addition to local peak heating and damage rates in the coil, total neutron-induced heating in the octopole coil set and their cryogenic ceses is also important because of the cost of cryo-refrigeration. To estimate this total heating, the end-cell line source under each octopole is integrated in $z$. These sources are then attenuated by the available shield thicknesses. The integral of the line source located under the small octopole is $32 \mathrm{~kW}$ and under the large octapole (excluding the region shared by the small octopole) is $30 \mathrm{~kW}$. Attenuating these sources with shield thicknesses set by the thinnest point found gives the following results: 


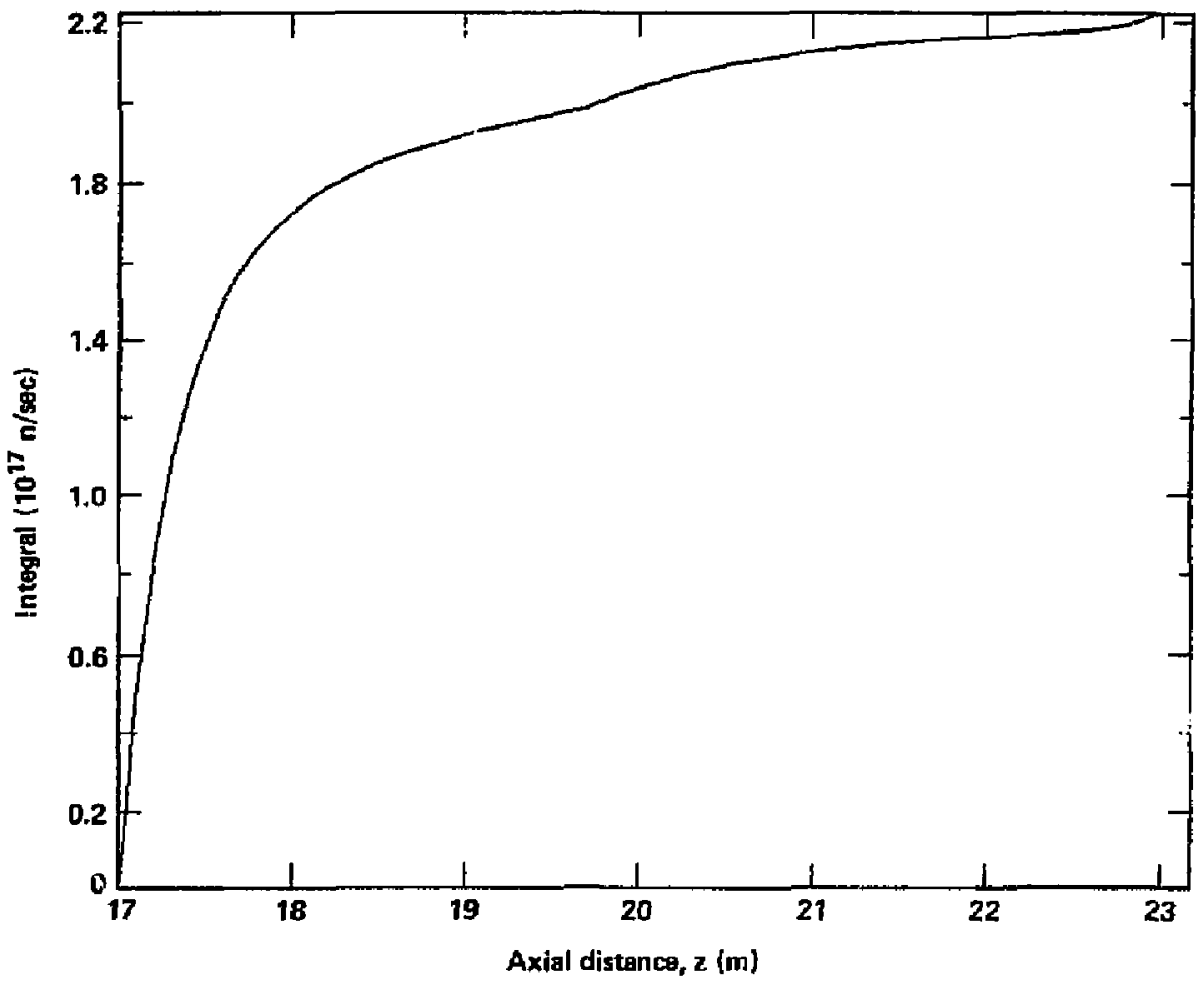

Fig. 3-49. Integr:11 of the end-cell neutron line source. 


\begin{tabular}{|c|c|c|c|c|}
\hline Region & $\begin{array}{c}\text { Source } \\
\text { (kW) }\end{array}$ & $\begin{array}{l}\text { Shielí } \\
\text { thicknes } \\
\text { (cm) }\end{array}$ & $\begin{array}{c}\text { Heatirig } \\
\text { coi1 and case } \\
\text { (kH) }\end{array}$ & \\
\hline Small octopole & 22 & 24 & 0.95 & . \\
\hline Large sctopole & $\underline{30}$ & 35 & 0.15 & \\
\hline Totals & 62 & & 1.10 & \\
\hline
\end{tabular}

This method overpredicts heating in the actopole because most of both coils have thicker shieljing than the minimum used here and berause the coils are not the solid-cylindrical anauli assumed here.

Summary

We have developed ar: ortopole end-cell configuration thet allows the small as well as the large octopole to be supetconducting. This pitulininary assessment is based on a quick and simple 1-y method of shieldity analysis. We found that peak heating and damage rates accired in the sisall octopole on the outboard end of the inner bor a where shield gogse is at a minimum. We predict that peak heating will be $1.4 \mathrm{mw} / \mathrm{cm}^{3}$ anc that the insulator danage limit at this point will be reached firgt; thar liniting coil life to 60 years. Total heating in all four of the octopole coiss and their sases is predic to be $2.2 \mathrm{~kW} ; 86 \%$ occurring in the small octopoles. Again, we emphasize thit this is a prelim nary assesment subject to considerable urcertainty, witjch will require significanty more work to -educe. That's the bad news. '...e good news is thet the heating and damage rates predicted with the 1-D nethod ere at least five times below the upper limits of acceptability. Thus, we can reasonably predict that this ead-cell config mation will be acceptabie.

ELECTRICAL SYSTEMS

The electrical aystems include the electric plant eyuipment of the ac zower syster, the power conversion for the confinement magnets, the power 
conversion for the microwave and neutral-beam injection (NBI) systems, and the instrumentation and control (ISC) systems.

\section{AC. Power Syacem}

The ac power system for FPD-III includes the main subatation, power distribution equiptent, and the feeder cables needed to supply the recycle power losds identified in Table $3-17$. This aystem also includes the $13.8-\mathrm{kV}$ busing, circuit breakers, and dc to ac inverters required for tne direct converters and steam-turbine generator if that option is selected. Referring to Table 3-17, the total recycle power needed for steady-state operation of FPD-III is about $133 \mathrm{MW}$. The table does not include the ICRH power that will be needed for plasma ignition during startup. Nearly half of the recycle power is needed to sustain the octopole end cells.

The FPD-III design has a relatively short central cell with thermal fusion power of $142 \mathrm{MW}$. Table 3-18 contains power generation data that would be appropriate if we decided to generate electric power rather then dump all the power to cooling towers. Because the machine is sma11, the engineering $Q$ is only 0.60 . From Table $3-18$, note that if all the heat were dumped to the cooling towers (no electric power generated), the reject heat load would be is $317 \mathrm{MW}$, which is about $33 \%$ more than the $237 \mathrm{MW}$ needed with the power generation equipmant.

Figure 3-50 is a block diagram of the proposed ac power system for FPD-III. Mnemonics used in this figure are identified in Table 3-19. A single 115-kV substation provides both the machine and facility power. The prime power for the neutral-beam injectors and ECRH gyrotrons is provided directly from the $13.8-\mathrm{kV}$ line. Two $4160-\mathrm{V}$ substations supply the prime power for the resistive coils, drift-pump coils, and eryogen-system motors. The 4160-V subgtations also supply the 480-v load centers for the low-voltage powe -distribution aystem. Two 2500-kV-A diesel generators provide 4160-V backup power to the essential electrical loads if a 115-kV power failure occurs. About $50 \mathrm{kV} \cdot \mathrm{A}$ of tunterruptible ac power is provided for instrumentation and control. 
Table 3-17. Recysle power estimates for FPD-III.

\begin{tabular}{lr}
\hline \multicolumn{1}{c}{ Recycle power load } & $\begin{array}{c}\text { FPD-III } \\
(M-W)\end{array}$ \\
\hline NBI power & 5 \\
ICRH power & 0 \\
ECRH power & 60 \\
Drift-pump power & 15 \\
Resistive-coil power & 23 \\
Superconducting-coil circuit power & 2 \\
Cryogenic system power & 12 \\
Cooling system and vacuum aystem power & 8 \\
Fueling and fuel processing systems & 8 \\
Facility power & 5 \\
& \\
Total recycle power (excluding tritium & 133 \\
c leanup power of 5 Mw) & \\
\hline
\end{tabular}


Table 3-18. Power generation data for EPD-III.

Power generation data

FPD-III

(MW)

Thermal fusion power

142

Total thermal power

184

Thermal power to cooling towers (PREJ)

237

Electrical power output of direct converters

14

Electrical power output of turbine generator

66

Total electrical power generation

80

Total recycle power

133

Net electrical power to utility line (PNET) -53

$\mathrm{QE}=\frac{\text { Total generated power }}{\text { Total recycle power }}$

0.60

FFFP $=100$ (PNET)

(\%) 


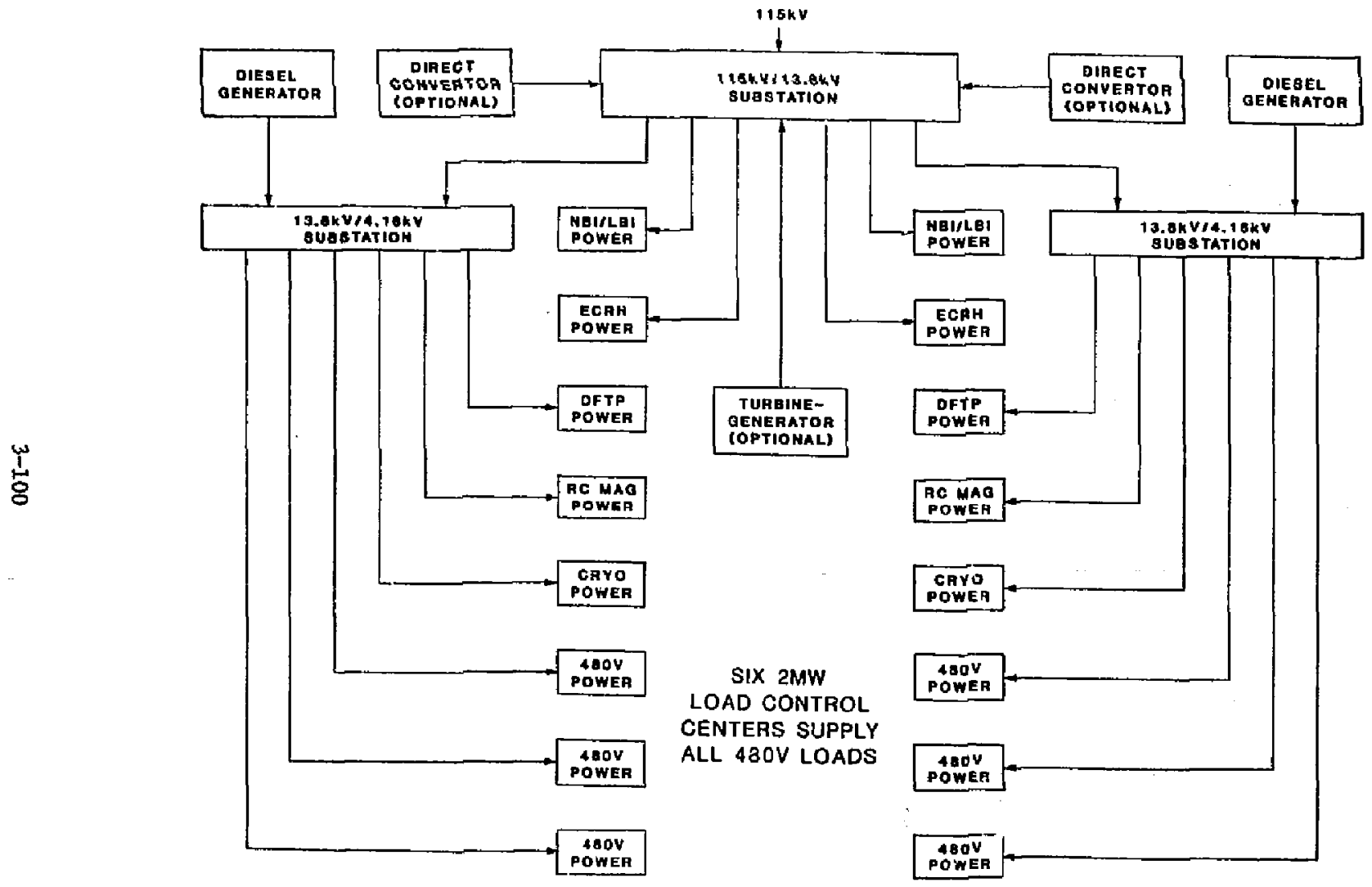

Fig. 3-50. Elementary block diagram of FPD-III ac power system. 
Table 3-19. Mnemonic definitions.

\begin{tabular}{ll}
\hline Mnemonic & \multicolumn{1}{c}{ Definition } \\
NBI & Neutral-beam injector \\
LBI & taser-beam injector \\
ECRH & Electron-cyclotron resonant heating \\
DFTP & Drift pump \\
RC & Reaistance conductor \\
SC & Superconductor \\
CRYO & Cryogenic \\
NPS & Number of power supplies \\
PSVOLT & Power-supply voltage \\
PSKA & Power-supply current (kA) \\
BUSLM & Bus length (m) \\
NBKRS & Number of dc circuit breakers \\
NDR & Number of dump resistors \\
EDRMJ & Maximum energy dissipated in a dump \\
& resistor (MJ) \\
PDRMH & Maximum power to a dump resistor (MW) \\
\hline
\end{tabular}


Electrical Power Conversion Systems

The electrical-power conversion systems include all the power supplies for the confinement magnets and power injection aystems for the end cell plasma. In addition, these systems include the protection systems for the magnets, local instrumentation and control, and all power cables and buses.

Power Converaion Systers for the Confinement Magnets. Two coil groups are located close to the plasma in relatively high magnetic fieldo, namely the inner choke coils and small octopole coils at both ends of the machine. The inner choke coils, of necessity, must be resistive rather than auperconducting because of the very high $24-\mathrm{T}$ field and because there is insufficient space to shield a superconducting coil insert from nuclear radiation in this region. The inner octopoles can be located so that adequate nuclear shielding is provided; in addition, the mognetic field is probably low ecough to allow the use of superconductors in winding the coil. The power-conversion systems and the ac power demand are based on supurconducting magnets fexcept for the choke coil inserts) to minimize the power-conversion cost and the ac power needed for operation.

Table 3-20 contains the key magnet power-conversion data for FPD-III. Mnemonics used in this table are defined in Table 3-19. The second colum of this rable refers to the cheracteristic arrangement of the power-converuicn system components for the magnet group. The four types of systems are identified with Ietters A through $D$; and generic characteristica of the systems are defined in Fige. 3-51 through 3-54.

The type A system of Fig. 3-51 shows the six main solenoids of the central cell connected in series to a comon power supply. A pair of energy-dump resistors are connected across each coil pair and additional dump registors are connected across each of the four large 60-kA current interrupters. A simple pneumatically-operated switch is used to implement a slow energy dump in lieu of more costly de circuit breakere. This is possible because of the very low voltage across the low-resistance dump resistor, $R_{S}$. 
Table 3-20. Magnet-power-conversion data for FPD-III.

\begin{tabular}{|c|c|c|c|c|c|c|c|c|c|}
\hline $\begin{array}{l}\text { Hagnet } \\
\text { group }\end{array}$ & $\begin{array}{l}\text { Circuit } \\
\text { type }\end{array}$ & NPS & PSVOLT & PSKA & BUSLM & NBKRS & NDR & EDRMJ & PDRMW \\
\hline Central cel1-6 & A & 1 & 16 & 60 & 100 & 4 & 12 & 400 & 30 \\
\hline Choke insert-2 & D & 1 & 240 & 100 & 100 & 0 & 0 & 0 & 0 \\
\hline $\begin{array}{l}\text { Choke BKGHD-2 } \\
\qquad(\mathrm{CB}-1)\end{array}$ & B & 1 & 6 & 9 & 100 & 2 & 4 & 14 & 5 \\
\hline $\begin{array}{l}\text { Choke BKGRD-2 } \\
\text { (CB-2) }\end{array}$ & B & 1 & 16 & 10 & 100 & 2 & 4 & 195 & 5 \\
\hline $\begin{array}{l}\text { Choke BKGRD-2 } \\
\qquad(\mathrm{CB}-3)\end{array}$ & c & 2 & 16 & 12 & 100 & 4 & 8 & 300 & 6 \\
\hline Octopole in-2 & B & 1 & 6 & 25 & 100 & 2 & 4 & 1.1 & 12 \\
\hline Octopole out-2 & B & $\mathbf{I}$ & 8 & 20 & 100 & 2 & 4 & 130 & 10 \\
\hline Bucking coil-2 & B & 1 & 6 & 22 & 100 & 2 & 4 & 45 & 11 \\
\hline Wirror coil-2 & B & 1 & 12 & 10 & 100 & 2 & 4 & 150 & 5 \\
\hline
\end{tabular}




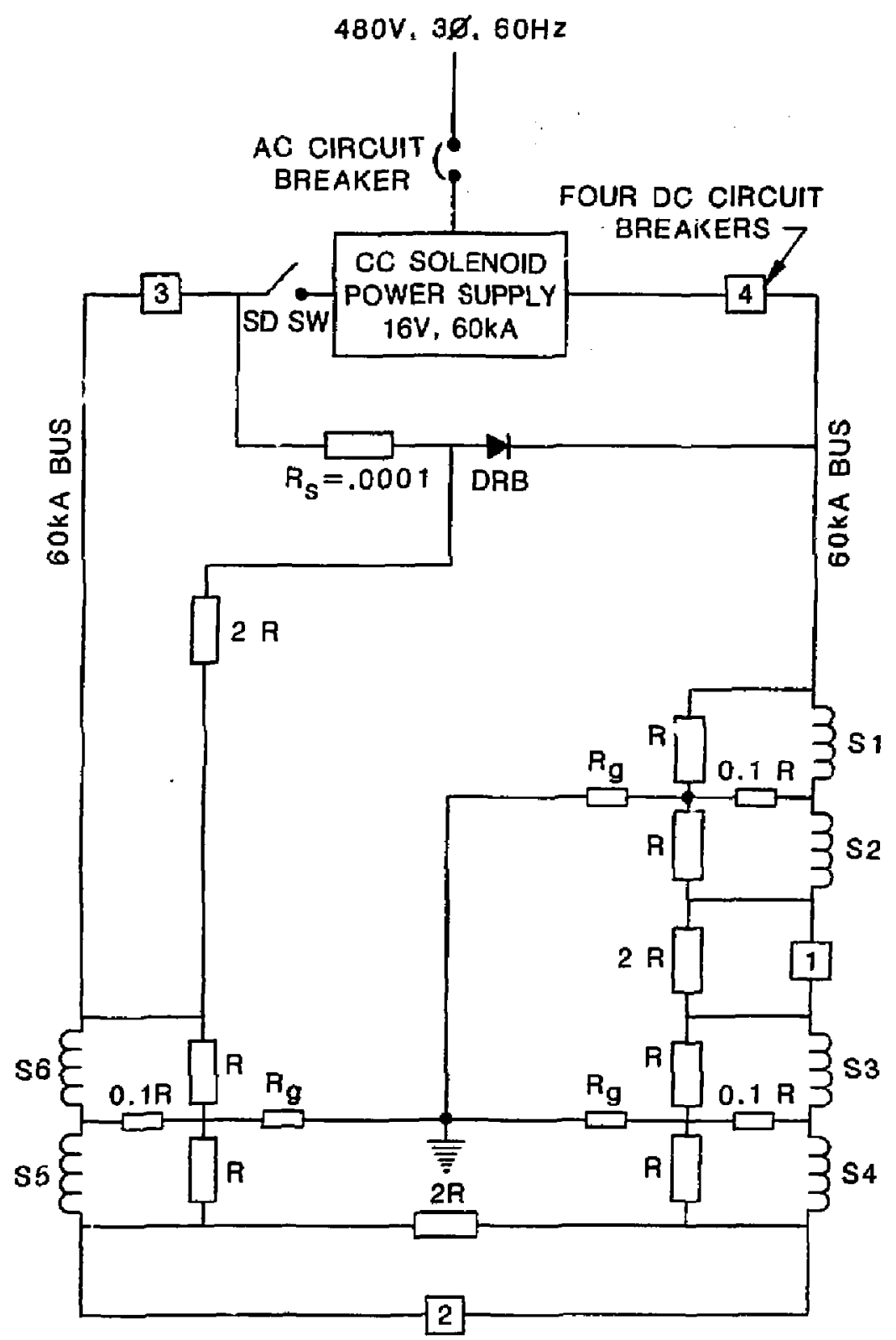

Fig. 3-51. Power conversion system for the central-cel1 solenoid magnets. 


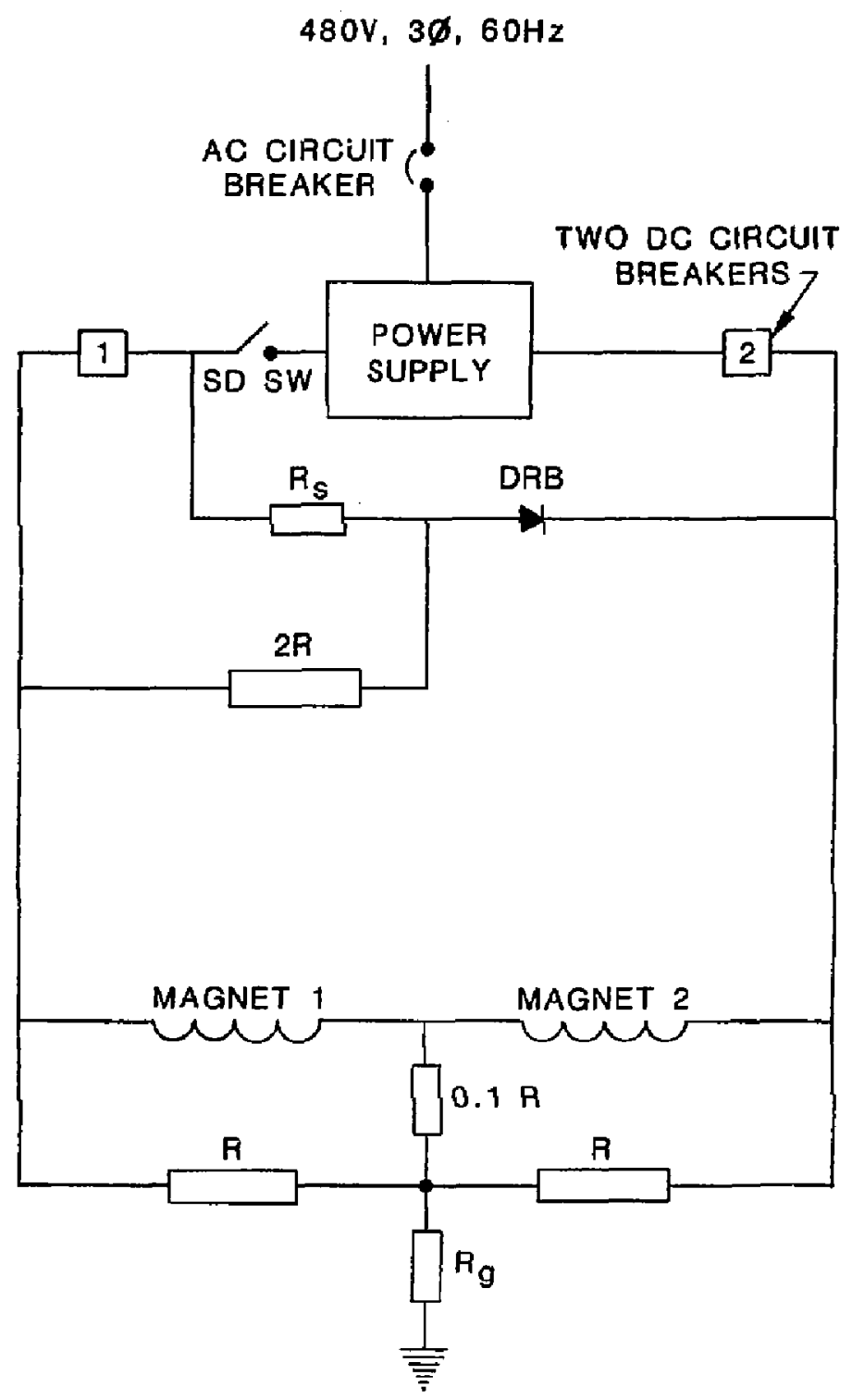

Fig. 3-52. Power convergion system for low energy coil pairs (Type B ckt). 


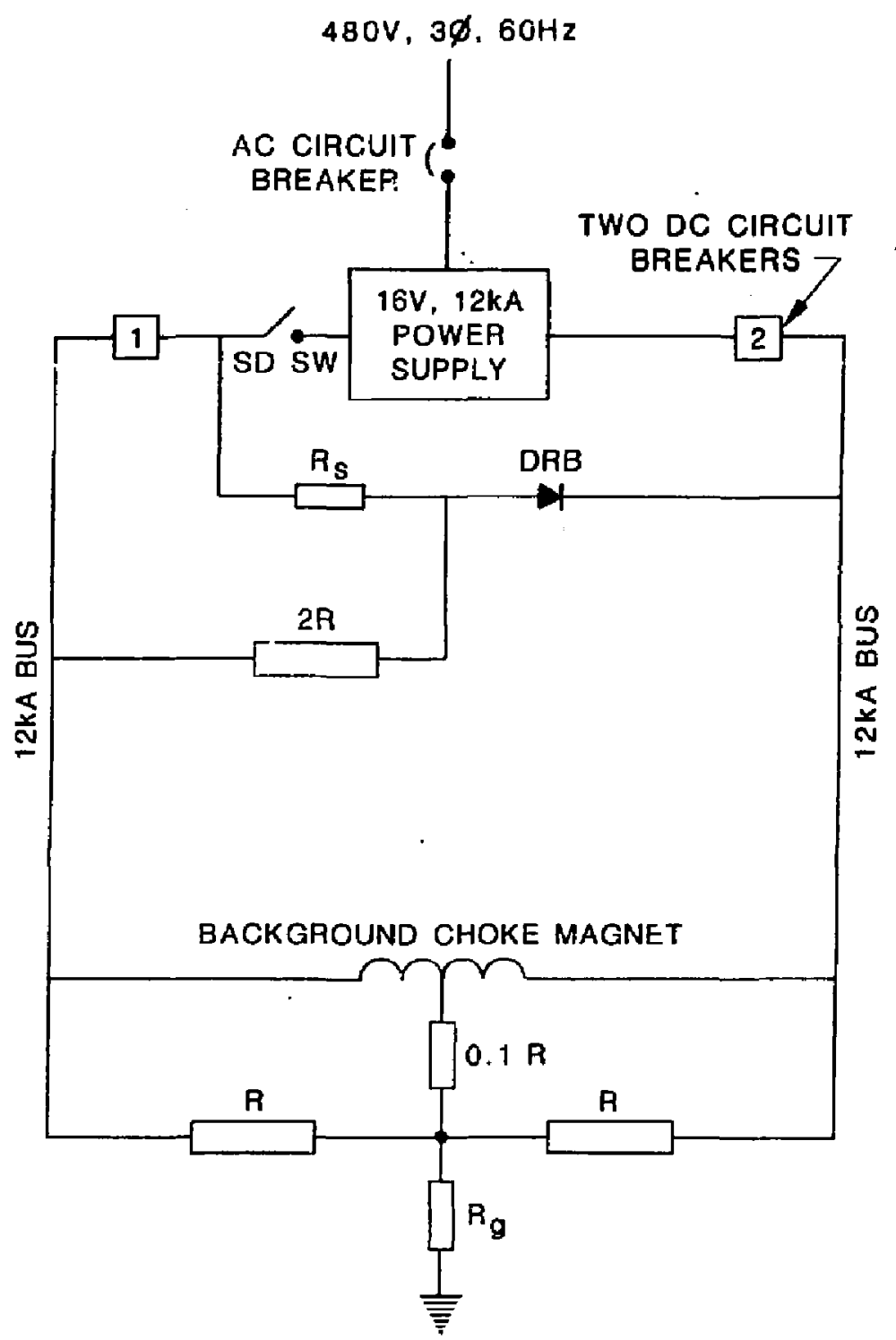

Fig. 3-53. Power conversion syaten for high energy background choke coils. 


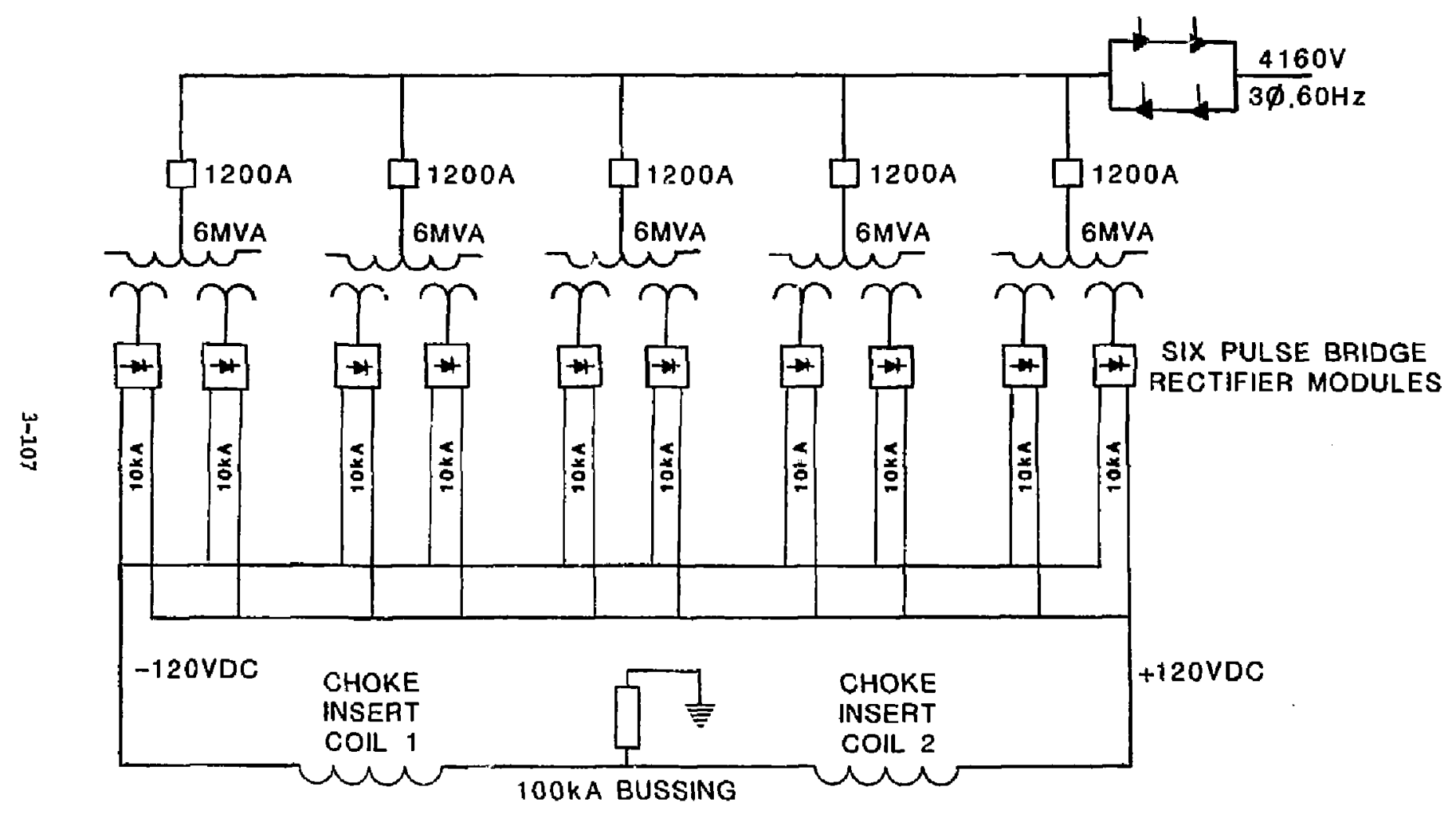

Fig. 3-54. Power conversion system for resistive insert choke coils (Type D ckt). 
Figures 3-52 and 3-53 show the type-B and $-C$ power-conversion aystems that apply to the two-coil and aingle-coil groupings of Table 3-19. The latter applies to high energy coils such as the outaide choke-background coil, which has a center tap and separate dump resistors across each half to provide adequate protection if a coil quench occura.

Figure 3 -54 shows the power-supply construction that we would probably use for the resistive-insert choke coils that require high current at much higher voltages than needed for the superconducting coils. A 4160-V substation would provide power to the rectifier trensformers through a group of four thyristors per phase. The thyristors control the ac input voltage to al1 five rectifier transformers. The ten rectifier-jodule outputs are connected in parallel to a water-cooled bus. A natural air-cooled bus has a large cross-bectional area that would require large penetrationd chrough the vauit and inconveniently large leads to the water-cooled insert choke coils. The water-cooled bus can be made of copper pipe to aupply water a well as power to the inner choke coils.

Referring again to Table 3-19, the group arrangements are somewhat arbitrary. Two power supplies may be provided for some groups in lieu of one larger power supply to reduce the length of busing and to provide separate control of current ia corresponding coils at boch ends of the central cell. The bus length is a total bus length for a group of magnetg (i.e., if two power supplies are included and the tatal bus length $4 \mathrm{~s} 100 \mathrm{~m}$, the bus digtance between the power supply and the coil pairs by maans of circuit breakers is only $25 \mathrm{~m}$. Busing from the main buses outaide the vault to the dump resistors is smaller and is ircluded in the cost of the dump rasistors. The cost of estimate, therefore, assumes the power supplies are adjezent co the reactor vault and located close to their respective coils.

Power Conversion for ECRh, NBI, and LBI Systams. Total power to plasma delivery requirements for the ECRH, negative-ion NBI, and the fueling laser-beam injectors (LBI) are given in Table 3-21. The valtage level and efficiency used to determine the ratings of the power supplies are also given in Table 3-21 under data colusina 2 and 3. Two power supplies were selected to 
Table 3-21. Major ECRH, ABI, and LBI power delivery requirements.

\begin{tabular}{lccc}
\hline \multicolumn{1}{c}{ Syatem description } & DC power \\
& $(\mathrm{MW})$ & $\begin{array}{c}\text { voltage } \\
(\mathrm{kV})\end{array}$ & $\begin{array}{c}\text { Efíciency } \\
(\%)\end{array}$ \\
\hline Mantle EGKH & 8.30 & 80 & 35 \\
Potential-teak ECRH & 0.20 & 80 & 35 \\
Therma1-barrier ECRH & 7.75 & 80 & 35 \\
Accelerator NBI & 1.61 & 475 & 32 \\
Fueling laser-beam injector (LBI) & 0.04 & 100 & 2 \\
\hline
\end{tabular}

an addition, there are also the smaller filament and arc power stipplies not identified here. 
provide each kind of power, one for each end of the machine. The ECRH power is generated with 26 gyrotrons, 13 for esch end of the machine. Each gyrotron is provided with a voltage regutator that also provides the necesary isolation so that common power supplies can be used. The powe sifply and regulator rating data are given in Table 3-22. Although we may be able to uge the gyrotron power supplies to charge the laser beamline marx generatora, for FPD-III we asgumed that separate power supplies are necessary.

Figure $\mathbf{3}-55$ is a one-line diagram showing the majur power supplies for plasma conditioning and fueiing. The $13.8-\mathrm{kV}$ circuit breakers are a part of the ac power aystem shown in Fig. 3-50. The regulators include voitage surge arrestors, reactors, filters, diodes, transistors, and vacuum tubes needed to provide voltage regulation and fast protection against faulta tist may oscur.

\section{Ingtrumentation and Control}

We aeed more time to completely addreas the FPB-III ingtrumentation and contral issues ( $I \dot{\alpha}$ ). In this section, we briefly describe the following four basic groups of I\&C:

1. Plant process,

2. Safety,

3. Plasma diagnostics,

4. Control-building supervisory control and data processing.

Each of these categories has both haxdware and software. The major Lypas of equipment in each group are identified in Table 3-23. All higber level control and display consoles associated with the plant process and safety I\&C are given under the last category. Table 3-24 identifies ten categories of plant process I\&C. If the fusion power Jf FFD-III is not used to generate electric power, the direct-converter system and turbine-generator systems will not be included in the faciiity, but wore I\&C may be needed in the heat-transport oystem for additional cooling loope and cooling towers. 
Table 3-22. Hajor de power supplies and regulators.

\begin{tabular}{|c|c|c|c|c|}
\hline \multirow[b]{2}{*}{ nescription } & \multirow[b]{2}{*}{ Quantity } & \multicolumn{3}{|c|}{ Rating } \\
\hline & & $\begin{array}{l}\text { Power } \\
\text { (MW) }\end{array}$ & $\begin{array}{c}\text { Voltage } \\
(\mathrm{kV})\end{array}$ & $\begin{array}{l}\text { Current } \\
\text { (A) }\end{array}$ \\
\hline RCRH power supplies & 2 & 25 & 85 & 300 \\
\hline ECRH power regulators & 26 & 2.0 & 80 & 25 \\
\hline NBI peier supplies & 2 & 2.5 & 500 & 5 \\
\hline LBI power stupplies & 2 & 1.0 & 100 & 10 \\
\hline
\end{tabular}




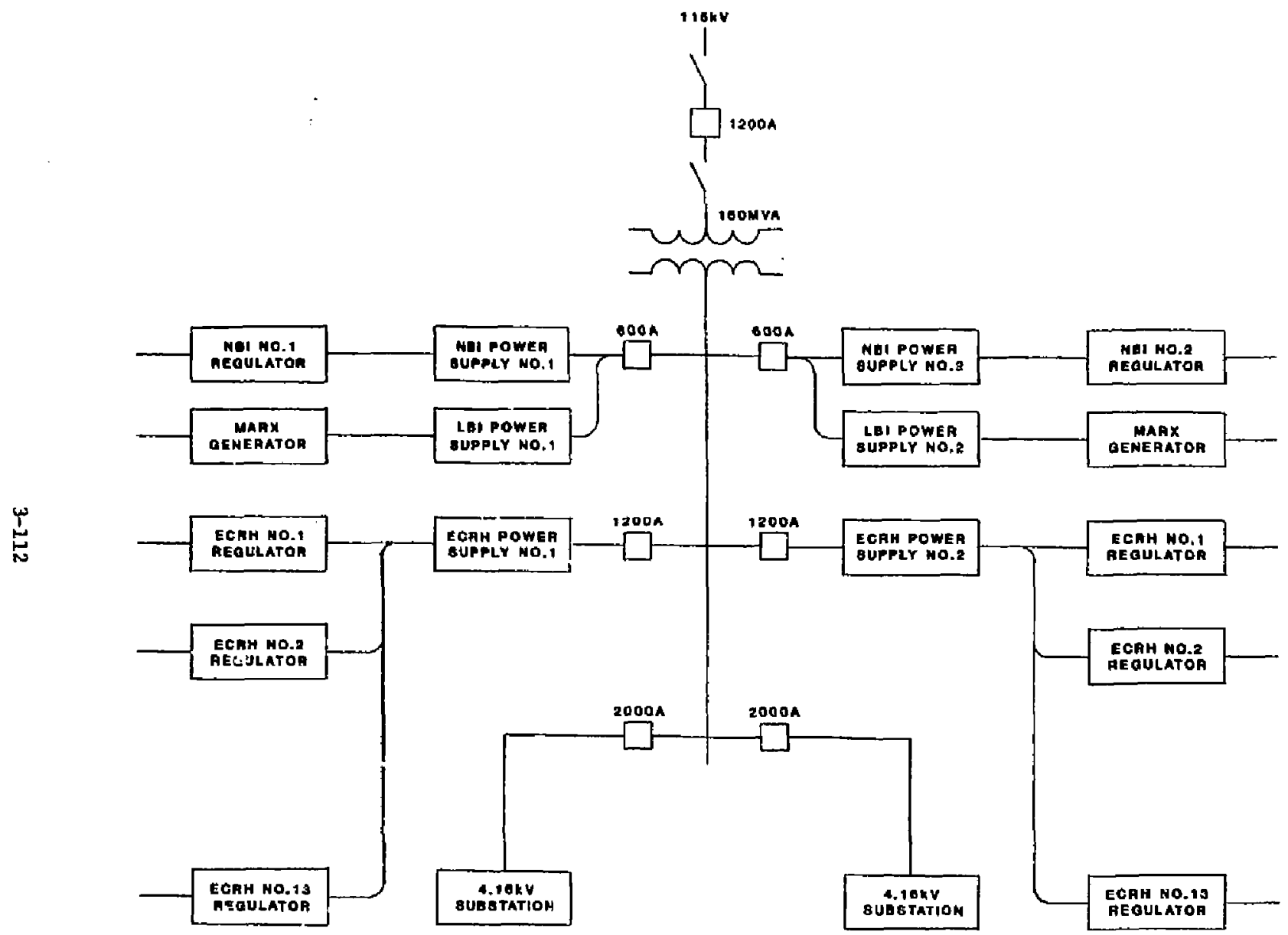

F18. 3-55. One-line dlagram of major plasma conditioning and fueling power supplies. 
Table 3-23. Categories and types of Iac.

Pioses: I\&C

Sensors

Signa 1 conditioning

Local processor:

Data multiplexers

Programable logic controller

Lacal controls and displays

Safety system I\&C

Sensora

Signal conditioning

Hard-wired controls

Local microprocessors

Programmeble logic controllers

Local controls and displays

Plasma diagnostics ISC

Sensors

Signal conditioning

Local computers and data storage

Data multiplexers

Optical data links

Local controls and displays

Remore console controls and displays

Supervisory control and data processing

Data acquisition fron CAMAC equipment

Optical data links

Large-acale cotuputers with large, rapid-accegs storage

Large mags starage for data archiving

Complete line of $\mathrm{I} / 0$ peripherals

Data links to other large-scale data processing facilities 
Table 3-24. Major categories of plant-procesa I\&C.

- Thermal power and heat transport syatema (seven major systems).

- Confinerent magnets and their crycgen system.

- End-cell power-injection aystems for plasma conditioning (ECRH, NB1, and drift-pump power).

- Fueling and fuel processing systems.

- Reactor and auxilizry component vacuum aysteme.

- Direct-converter and halo-scraper systems.

- Steam-power-generating systems.

- Generator and power distribution system.

- Building facilities such as HVAC, lighting, fire alarm and control, radiation monitoring, and security systems.

- Remote handling consoles and dieplays for removal, repair, and maintenance of reactor components and equipment in the reactor vault. 
Seven groups of heat-transport systems on FPD-III require coolant flow controls to satisfy temperature congtraints. These seven groups consist of the following:

1. Liquid lithium-lead cooling syatems for the central-celt breeding blankets.

2. Water-cooling systems for auxiliary shielding components and halo-scraper dumps.

3. Water-cooling systems for the resistive-conducting choke-coil insert coils, busing, and power supplies.

4. Water-cooling systems for ECRH, drift pump, and NBI equipment for end-cell plagms conditioning.

5. Water-rooling systems for the direct-converter collectors.

6. Water-cooling systems for the secondary loopa that carry the heat to the cooling towers.

7. Feedwater system if the electrical power generation option is selected.

Water-cooling systems generaly require water treatment systems that also need ISC. Some of the cooling systems that interface with the plasma or breeding blanket through a single wall require radiation monitoring instruments to detect tritium leakage. Pump control of coolant flow usually requires speed control of an adjustable speed drive. Valve control of flo ustally reguires pressure control of a valve position controller.

All but two of the major process control categories of Table 3-24 have safety related I\&C that must be able to terminate plant operations to prevent equipment/reactor damage and to isolate critium leakage contamination. Loss of coolant flow can overheat reactor components and electrical equipuent. Instrumentation must be provided to detect loss of coolant flow to many components and shutdown the heat source, which can be the reactor or an electrical-power supply. Thia generally requires shuting down the reactor and turning off power supplies. A 108 of plasma detector is needed to guickly turn off a11 neutral-beam injectors and terminate reactor operations. Superconducting-manget quench detectcrs and detectors of events that could 
lead to a quench must be provided. These detectore must be able to initiate rapid discharge of the superconducting magnets into energy-dump reaistors. Radiation monitoring of cooling systens, reactor vauls and fuel pracessing equipment, and asscciated buildings is needed for detecting tritium leakage and terminating reactor operations. Inatrumentation and control systems are needed for turning on large blower motors and operating valves for cleanup.

Some plasm diagnostic instrumentation is needed to control the reactor plasma density, temperature, potential, and reaction rate (neutron flux). Table 3-25 liacs the plasma diagnostics being considered for FPD-III, in addition to the type of measurement, mnemomic abbreviations, and type of reactor penetration required.

One of the most seriaus FPD $36 \mathrm{C}$ problems is the very limited space available between magnet coils for the diagnostic ingtrumentation needed to control the reactor. For FPD-III, we addresged this problem by gdding a small sector in the middle of the central cell dedicated to providing penetrations needed for the control and diagnostic instrumentation, and for the fuel injectors. Figure 3-56 is a secti - view of the proposed sector showing two 24-in. horizontal-receiving tubes and two 24-in. vertical-receiving tubes. One of the horizontal tubes is dedicated to the fueling module. The other horizontal tube is dedicated principally to microwave diagnostics, but may rave a horizontai line-of-sight penetration to view a vertical laser beam or ion beam. The upper vertical $24-\mathrm{in}$. tube is devoted to passive and active optical diagnostics. These diagnostic modules are described in Ref. 25.

The bottom 24-in. tube contains a module having eeveral line-of-sight penetrations for directly viewing the plagma from the underside and for terminating a diagnostic laser beam or ion beam in an energy dump. The underside receiver diagnostics and energy dumps ace mounted in a shielded container supported on horizontal rails for removal and replacentent, if jacessary. The horizontal diagnostic-insert modules can also be removed with a portable, horizontal rail assembly. The vertical assembiy is readily removed with the ovethead ctane.

The end-cell diagnostics also need further investigation. Ion spectrometers used to measure the potential barrier height. can be located on the end covers of the reactor. They require holes through the direct 
Table 3-25. Selected plaana diagnostics.

\begin{tabular}{|c|c|c|c|}
\hline $\begin{array}{l}\text { Quantity } \\
\text { measured }\end{array}$ & $\begin{array}{l}\text { Type of } \\
\text { measurement }\end{array}$ & Mnemonic & $\begin{array}{l}\text { Type of } \\
\text { penetration }\end{array}$ \\
\hline Vacuun pressure & Ion gauge & BGP & Offiset \\
\hline Neutron flux & $\begin{array}{l}\text { Neutron counters: fission } \\
\text { chambers, scintillation } \\
\text { detectors }\end{array}$ & NCT & Shielded \\
\hline Heat flow (power) & Calorimeter & CAL & $\operatorname{Los}^{\mathbf{a}}$ \\
\hline Integrated heat flow & Bolometer & BOL & LOS \\
\hline Ion current & Charged particle flux & GPF & LOS \\
\hline $\begin{array}{l}\varphi_{\text {max }} \text { particle } \\
\text { paxallel energy }\end{array}$ & $\mathrm{E}_{\|} \mathrm{B}$ ion spectrometer & ISP & LOS \\
\hline $\begin{array}{l}\phi_{c} \text {, particle per- } \\
\text { pendicular energy }\end{array}$ & Neutral flux spectrometer & NES & LOS \\
\hline $\int \mathrm{n}^{\mathrm{T}} \mathrm{e} d x$ & Electron-cyclotron emission & ECE & offset waveguide \\
\hline$\phi, B^{T \text { TLDE }}$ & Electromagnetic fluctuation & EMF & offset coaxial line \\
\hline $\int n_{e} T_{e} d l(10 w$ & Microwave interferometer & MIN & Offset waveguide \\
\hline $\int n_{e^{T}} e_{d \ell \text { (high }}$ & FIR laser interferometer & FLI & Offset mirrors \\
\hline $\begin{array}{l}\text { Ion temperature } \\
\left(\mathrm{D}_{2} \text { phase) }\right.\end{array}$ & Doppler shift spectroneter & DSS & offset mirrors \\
\hline Impurities, $n_{e}, T_{e}$ & U1traviolet spectrometer & UVS & Gffset mirrors \\
\hline Color, impurities & $\begin{array}{l}\text { Plasma image (television } \\
\text { optics for startup only) }\end{array}$ & PIM & Offset mitrors \\
\hline Neutron fluence & Neution activation system & NAS & $\begin{array}{l}\text { Offset pneumatic } \\
\text { tubing }\end{array}$ \\
\hline $\begin{array}{l}\text { Ion temperature } \\
\left(\mathrm{T}_{2} \text { phais }\right)\end{array}$ & Neutron energy spectrometer & NSP & LOS \\
\hline
\end{tabular}


Table 3-25. (Continued,)

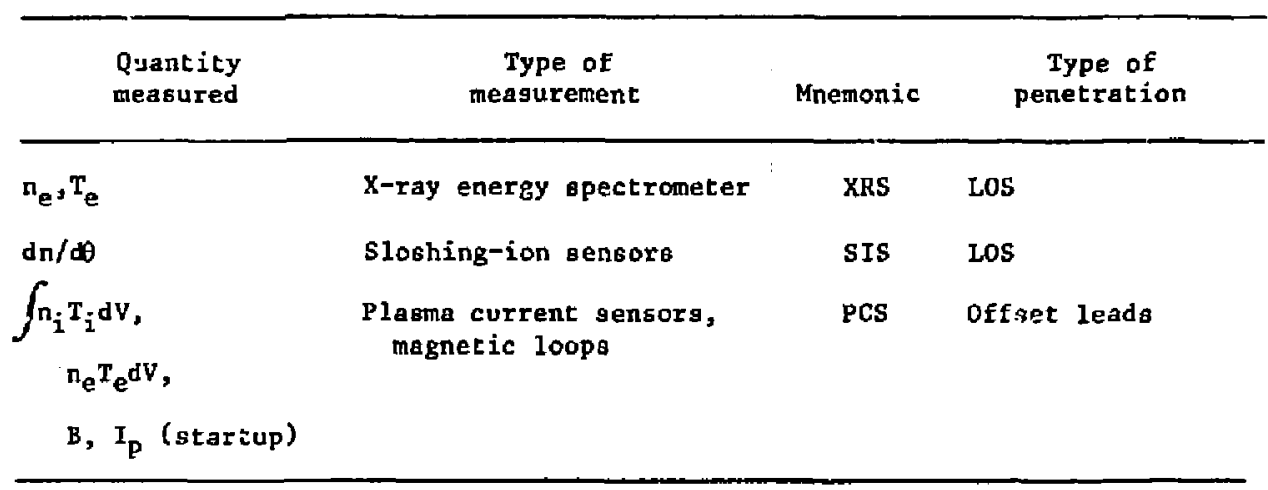

${ }^{a}$ LOS $=1$ ine of sight. 


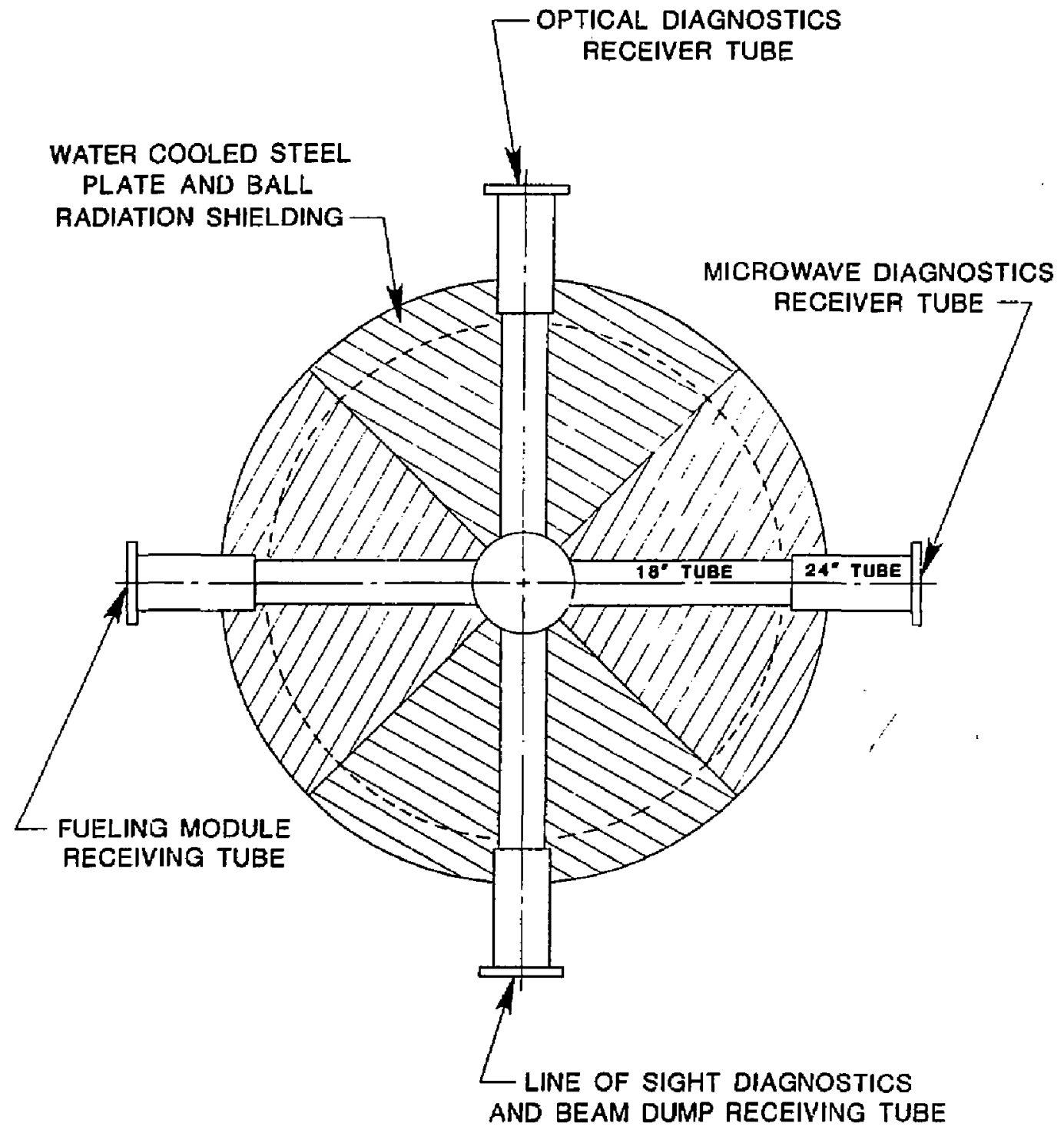

Fig. 3-56. Secticn view sketch of the ingtrumentation and fueling sector located in the middle of the central cell. 
converter collectors. This diagnostic instrumentation is described in detail for HFTF-a+T in Ref. 25. Space between the octcpole-megnet-coil windovg is largely devoted to EGRH, HBI, and drift-pump power injectora. However, there appears to be limited space remaining for neutron, optical, and microwave rypes of plasma diagnostics. Location of these diagnostics in the actopole region will be addressed during the MINIMARS study to be accomplished in FYB5. The supervisory control and data acquisitior system for FPD-III includes the following:

- All large scale data processors and iheir peripherals,

- Plant process consoles containing controls and displays.

- Data links to the lower-level local computers and CAMAC :qquipment.

The data acquisition system includos all sensors and signal conditioning not dedicated to control systems, analog to digital conversion, and data control and transmisaion to the large scale data processors. The CAMAC modules. generally provide the front-end functions. A large part of the supervisory control and data acquisition cost is the applicaticns software generally needed for a new generation of computers. If the software developed for MFTF-B could be adopted to a large extent, the software cost could be considerably reduced.

Compared with MFTF-B and Tokamak Fusion Test Reactor (TFTR), the diagnostic instrumentation cost for FPD-III can be reduced by using most1y essential diagnostics that have been previously developed. More process Idc will be required thar for existing ingtallations because of the rirect converters, neutron shielding, blankets, halo-dump modules, and the czitium-orocessing and fueling system. The safety system must be augmented to include the fueling and tritium processing facilities. If no power generation options are selected and substantial use of past development of diagnootic sensors and softwete are fully utilized, we should be able to provide the Isc for about the same cost as the I\&C for MFTF-B. 
The FPD-III tritium systems include equipment for tritium storage, recovery of tritium fro:n the breeding blarket, and cleanup/recovery of tritium released to the atmosphere of the reactor, hat cell, radwaste, or tritium-processing buildings. The major input parameters and assumptions that we used for sizing and evaluating the tritium-aystem design are listed in Table 3-26.

We assume a fueling rate by pellets of $30 \mathrm{~g} / \mathrm{h}(18 \mathrm{~g} / \mathrm{h}$ of tritium and $12 \mathrm{~g} / \mathrm{h}$ of deuterium). Since we expect the FPD-III device to have the capability frr long-duration burns, storage of sufficient tritium to fuel the device without continuous processing is impractical. For example, a $1.8-\mathrm{kg}$ inventory of tritiun is needed to fuel $\mathrm{FPD}-\mathrm{III}$ far a $100-\mathrm{h}$ burn if no fuel recycling is used. Therefore, the tritium system is designed to process the fuel on a steady-state basis. Uranium-storage beds, used to stcre the tritiun and deuterium cycled through the reactor, are sized to a capability of $60 \mathrm{~g}$, which corresponds to $2 \mathrm{~h}$ of operation. The tritium burnup rate corresponding to the 150. MW fusion power for FPD-III is about $1 \mathrm{~g} / \mathrm{h}$.

The breeding-blanket design fcr FPD-III provides a tritium-breeding ratio slightly greacer than 1 to compensate for the burned tritium. The liquid-LiPb breeding material, aloo used as the blanket coolant, is processed continuously to remove the bred tritium with an equilibrium concentration of 0.001 ppm.

The atmospheric-recovery system is designed to cleanup tritium released into buildings that could potentially contain tritium. These buildings include the reactor building, tritium-processing building, radwaste building, and hot-cell building. Atmospheric recovery units of the type used in Tritium Systems Test Assembly (TSTA) are tacated in the tritium-processing building. The compressors, catalytic oxidizers, driers, and storage tanks are sized to handle a release of $10 \mathrm{~g}(96 \mathrm{kCi})$ of tritium in any of these buildings. The maximum cleanup time allowed before reaching a tritium concentration of $50 \mu \mathrm{Ci} / \mathrm{m}^{3}$ is five days. The atmospheric recovery system design approach selected for FPD-III uses a single set of equipment for processing all buildinga. Ducts and tritium monitoring instrumentation must be provided in 
Table 3-26. The FPV-III tritium systems parameterg and assumptions.

Eusion power (ww)

150

Fueling rate $(\mathrm{gm} / \mathrm{s})$

Tritium $1 B$

Deuterium

12

Tritium breeding ratio

1.1

Tritium concentration in LiPb blanket ( $\mathrm{ppm}$ )

0.001

Sizes of tritium-containing buildings $\left(\mathrm{m}^{3}\right)$

Reactor building

49,000

Trit ium-processing building

10,000

Radwaste building

1,100

Hot cell

13,000 
all potentially contaminated areas. The syotem size is determined by the largest building, which is the reacior building with a volume of $49,000 \mathrm{~m}^{3}$. Therefore, the required atmospheric pracessing rate is $4.0 \mathrm{~m}^{3} / \mathrm{s}$. With this processing rate, the smaller tritium processing building $\left(10,000 \mathrm{~m}^{3}\right)$ can be cleaned up to a tritium concentration of $50 \mu \mathrm{Ci} / \mathrm{m}^{3}$ in less than two days.

This atmospheric-recovery system for FPD-III differs from the FPD-I and FPD-II approaches, which included separate equipment for handling each building. The FPD-III reference design uaves about $\$ 3.7$ million dollars compared with the FPD-I and -II systems.

Estimated tritium inventories in various components for FPD-ILI are ligted in Table 3-27; the total tritium inventory is $0.22 \mathrm{~kg}$ (2.1 MGi). 
Tále 3-27. Tritium inventories in FPD-III (gramg).

\begin{tabular}{lr} 
Reactor building & \\
Reactor structure & 30 \\
Halo cryopumps & 6 \\
Pellet fueler & 6 \\
Blanket & -1 \\
$\quad$ Total reactor building & 74 \\
& \\
Tritium processing & \\
Storage & 36 \\
Pellet preparation & 13 \\
Fuel cleanup & 44 \\
Cryogenic distillation & 54 \\
$\quad$ Total processing & 147 \\
$\quad$ Total & 221 \\
\hline
\end{tabular}


1. B. G. Logan, C. D. Henning et al., MARS Mirror Advanced Reactor Study, Final Report, Comercial Fusion Electric Plant, Vols. 1A and 1B, Lawrence Iivermore National Laboratory, Livermore, CA, UCRL-53480 (1984).

2. Fusion Power Demonitrations I and II, J. N. Doggett, Ed., Lawrence Livermore National Laboratory, Livermore, CA, UCID-19975-L (1985).

3. F. E. Coffield et al., "Polarizing Holographic Reflector for Electron-Cyclotron Resonatit Heating (ECRH) on the Tandern Misror Experiment-Upgrade (TMX-U)," in Proc. of the IEEE, 10th Symposium on Fusion Engineering, December 5-9, 1983.

4. J. J. Yugo et al., "Quasi-Optical Hicrowave Bean System for ECRH in MFTF-5," presented at the AYS 25th Annual Meeting of the Division of Plasma Physicists, Los Angeles, CA, paper 6U10 (November, 1983).

5. W. H. McAdans, Heat Transmission (McGraw-ilill Book Co., Hightstcom, NJ, 1954).

6. M. Abdou et a1., "Impurity Control and First Wall Engineering, Chapter VII," in U.S. FED-INTOR Phase II Critical Issues, W. Stacey, Ed., PFD INTOR/ICRW82-17 (1982).

7. D. L. Smith, J. N. Brooks, D. E. Post, and D. Heifetz, "A Physical Sputtering Code for Fusion Applications," in Proc. of 9th Symposium of Engineering Problems of Fusion, IEEE Pub. No. 81CH1715-2 NPS (1981).

8. J. Brooks, Argontue National Laboratory, Argonne, IL, private communication (1984).

9. F. G. Hammitt, "Cavitation and Liquid Impact Erosion", in Wear Control Bendbook, American Society of Mechanical Engineers (1980).

10. F. G. Hamite, Y. C. Huang et a1., "Volume Loss Dus cu Cavitation or Liquid Impingement," in Characteristics and Determination of Erosion Resistance, American Society of Testing Materists Special Technical Pub1ication 474 (1970).

12. B. J. Milleville, "The Case for Higher Velocities in Feedwater Piping," in Proc. of the 30th Annual Meating of the American Power Conference, Chicago, IL (1968). 
12. P. Cohen, "Water Coolant Technology of Power Reactors," in Monograph Series on Nuclear Science and Technology, American Nuclear Society (1980).

13. J. Schultz, Degign Practice and Operational Experience of Highly Irradiated, High Performance NormeI Magnets, Masachusetts Institute of Technology, Plasma Fusion Center, Cambridge, MA, PFC/RR-82-25, DOE/ET-51013-54-UC20B (1982).

14. G. Jenks, Effects of Reactor Operation on UFIR Coolant, Dak Ridge National Laboratory, Oak Ridge, TN, ORNL-3848 (1955).

15. E. J. Hart et $\mathrm{a}$., "The Decomposition of Light and Heavy Hater Boric Acid Solution by Nuclear Reactor Radiations," in Proc. of the Intern. Conf. Peaceful Uses At. Energy, Geneva, 1955, 7, 593 United Nations, NY (1956).

16. W. D. Mackintosh et al., Radiolytic Gas Production in Liquid Control Elements for Nuclear Reactorg Using Boron as an Absorber, Atonic Energy of Canade Ltd., Ottawa, Ontario, Canada, AECL-2670 (1967).

17. D. Whyte, Forest Park Research Center, Westinghouse Corp., Pittgiurg, PA, private communication ( 1984 ).

18. M. Harmsen, "System Description SD-5G4 Demineralized Water Systems," Tokamak Fusion Test Reactor, Rey. 2, Princeton Plasma Physics Laboratory, Princeton, NJ (1982).

19. W. R. Smythe, Static and Dynamic Electricity (McGraw-Hill Book Co., Hightecown, iJ , 1950).

20. J. H. Fink, G. H. Hamilton, and J. I. Erickson "A 24-kH Neutral Beam Injector of $400 \mathrm{keV} \mathrm{H^{ \circ }}$," in Pro of the $8 \mathrm{th}$ Symposium on Engineering Problems of Fusion Research," Inst. of Electronic and Electrical Engineero, Berkeley, CA (1979).

21. E. I, DuPont de Memours, Vespel Parts, Product, and Design Manual, Wilmington, DE (1980).

22. M. Baskes, W. Bauer, and K. Wilson, Tritium Permeacion in Fugion Reactor Firgt Walla, Sandia Laboratory, Livermore, CA, SAND-82-8698 (1982).

23. M. Baskes, "A Calculation of the Surface Recombination Rate Constant for Hydroger Isatopes on Metals," J. of Nuc1. Mater. $92,318-324$ (i980). 
24. D. Dorn, Lawrence Livermore National Leboratory, Livermore, CA, private communication $(1984)$.

25. MFTF- $\alpha+T$ Progres Report, Fusion Engineering Design Center, Dak Ridge Natiena1 Laboratory, Oak Ricige, TN, ORNL/FEDC-B3/9, to be published. 


\section{Section 4}

\section{Maintenance and Component Replacement}




\subsection{MAINTENANGE AND COMPONENT KEPLACEMENT}

REQUIREMENTS

The configuration for FPD-III is an iteration of the FPD-II design, ${ }^{1}$ and except for the end cell, the maintenance, ond component-disassembly requirements, are essentialiy the same. The FPD-III end cells contain a magnet system made up of a choke-coil assembly, a major and minor octopole assembly, and a mitror/shaping coil assembly. Except for the choke coils, each of these magnet-system assembiles are interlocked to some degree. Hence, vertical removal through the end-cell hatch is more complex for FPD-III.

The biolcgical shield around the vacum veseel is designed to limit the surface activation to $0.5 \mathrm{mrem} / \mathrm{h}, 24 \mathrm{~h}$ after device shutdown. Therefore, personnel access in the vault is permitted for the following:

- Inspection;

- Disasgembly of electrisal, coolunt, and structural connections;

- Setup of naincenance equipment if the device shield is not disassembled.

This approach is identical to that of FPD-I and -II. ${ }^{1}$ The dose rate of 0.5 mrem/h was establighed to meet the as low as reasonably achievable (ALARA) guideline that limits personnel exposure to less than or equal to $1 \mathrm{rem} / \mathrm{y}$. END CELLS

We based the design of the end cells on removal of the primary components as modular units. The direct-converter/halo-scraper assembly is removable as a module and is interral with the shielded access hatch shown in Fig. 4-1. The removal of this assembly is accomplished as a vertical lift using the primary overherd crane (300 ton) supplemented by remote operations using ane or both crane-mounted manipulator aystems.

The chake-cail assembly is removed through the main end-cell hatchway after disassembly of the appropriate shield modules and service connections. 


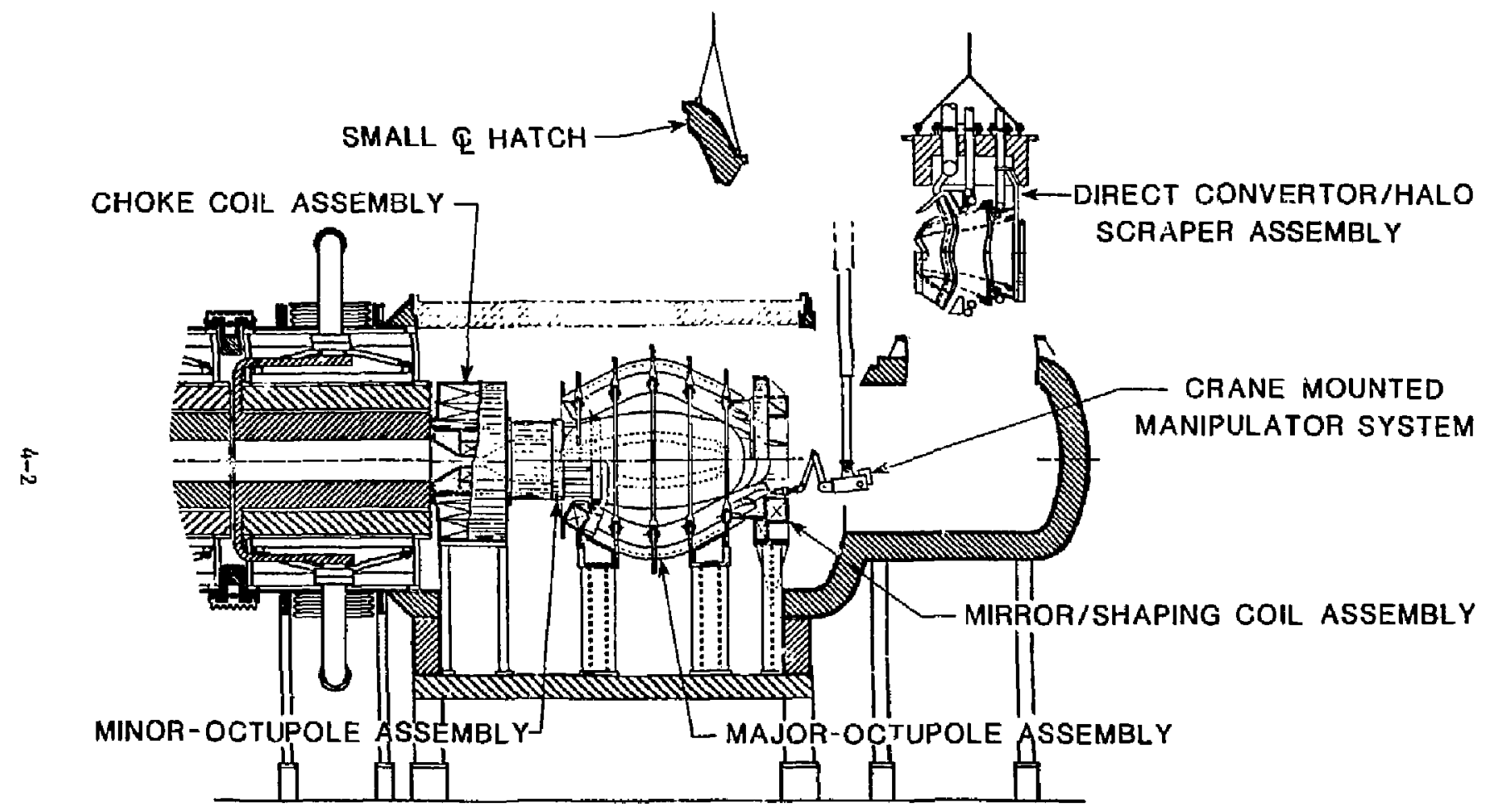

F1g. 4-1. Removal of structural attachments between octopole frames and mirror/shaping coil assembly. 
This module consists of three superconducting coilg and one resistive coil with integral shielding. This is the heaviest component in the end cell with an estimated weight of 126 tonnes. Because of the high-operating magnetic field of the resistive coil and its proximity to the plasma, the choke coil assembly is not considered to be a lifetine component. Hence, some finite number of replacements are expected. The frequency of replacement and the duration of downtime can be used to determine the impact on availability, which becomes the basis for uaing either a complete spare module or replacing of the copper ingert in a gerial hot-cell operation.

For FPD-III the primary problem is replacement of the minor octopole assembly. This is the smallest end-cell component (7.5 ton) (see Table 4-1), but, because it is nested within the major octopole, its removal requires disassembling either one or two of the major octopole window frame coils, iepending on which end cell is affected. Figure 4-1 show the arrangement of the coil system in the end cell. The octopole coils have a 45-deg axial rotation to each other between the east- and west-end cells. Because of this rotation, removal of the minor octopole is more complex in one end cell (compars Figs. 4-2 and 4-3).

Removal of the mirror octopole requires seven primary operations. All of these operations must be accomplished remotely; a brief description of each is discussed below:

1. Remove the end-cell hatch to provide access for all subsequent overhead operations. The hatch is otored in the vaulc "laydown" area and also serves as the holding fixture for the frame coils that are subsequently removed from the end cell. Disassembly of the structural attachments and the vacuum seal of the hatch may be accomplished with personnel berore pumping out the shield water contrined in the hatch.

2. Disconnect electrical and cnolant 2 ines to the major octopole frame(s) that will be removed, and also disconnect those lines to the minor octopole.

3. Remove the upper link attachments on the structural ribs of the frame coils (Figa. 4-2 and 4-3). 
Table 4-1. Approximate weights for end-cell components.

\begin{tabular}{lc}
\hline \multicolumn{1}{c}{ Component } & $\begin{array}{c}\text { Height } \\
\text { (tonnes) }\end{array}$ \\
\hline Choke-coil asgembly & 126.0 \\
Major octopole (per frame) & 42.5 \\
Minor octopole assembly & 7.5 \\
Mirror coil & 15.0 \\
Shaping coil & 35.0 \\
Annular shield module & 115.0 \\
End-cell main hatch & 85.0 \\
\hline
\end{tabular}

ancluding estimates for structure. 


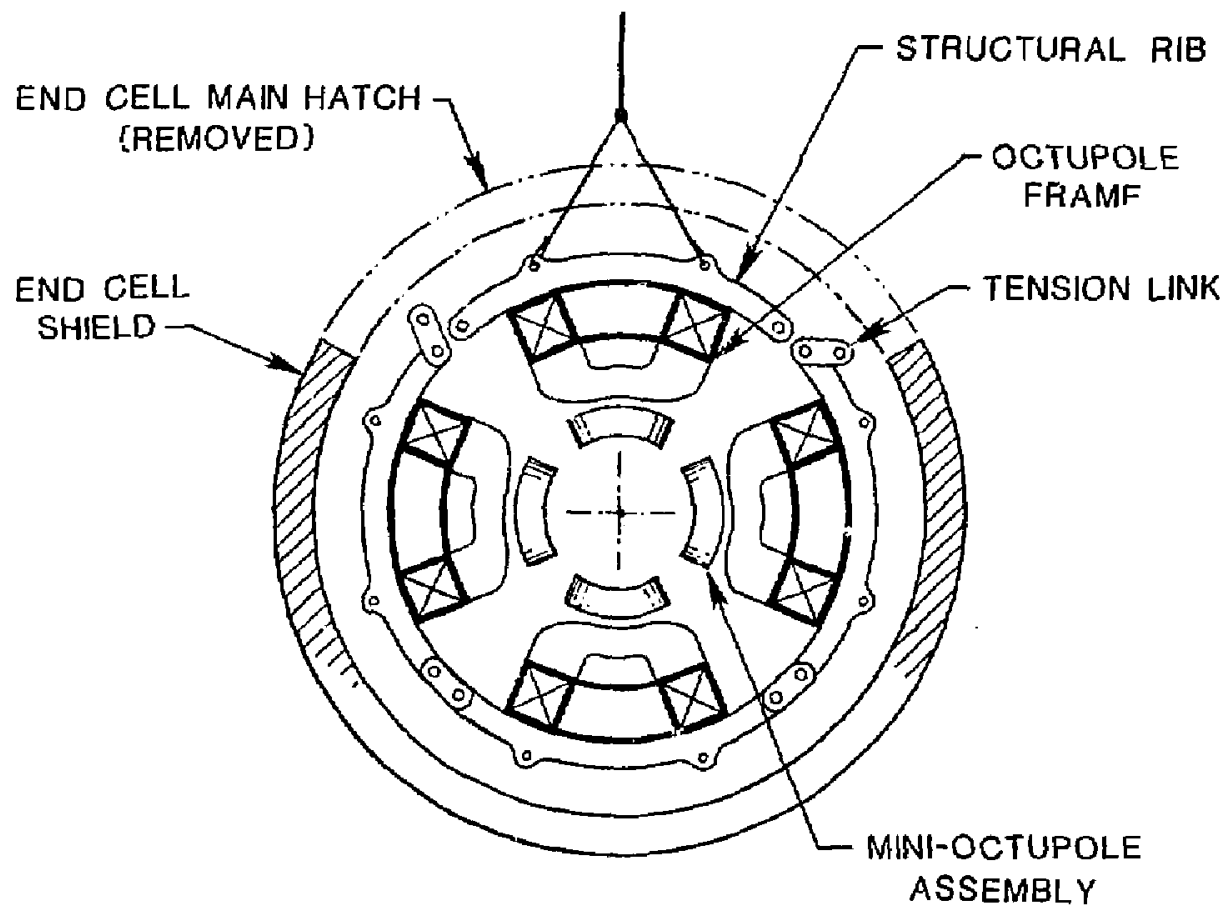

Fig. 4-2. End cell which requires removal of one octopolf i. ame for access to the mini-actopsle. 


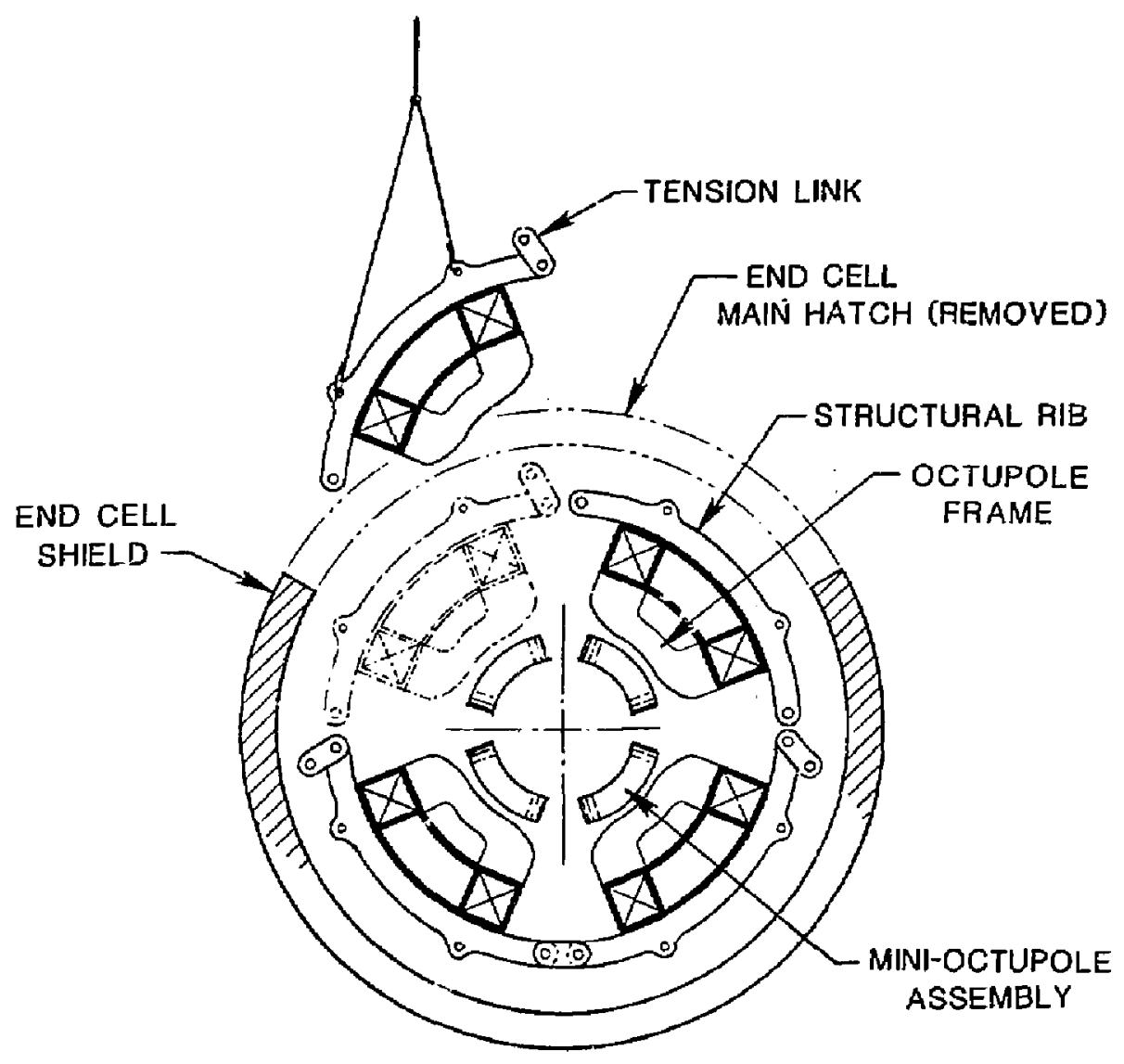

Fig. 4-3. End ce11, which requires rewoval of two octopole frames for access to the mini-octopole. 
4. Remove the small centerline hatch for access to the structural attachments between the octopole assembly and the mirror/shaping coil assembly (Fig. 4-1). Only those attachments into the frame that is being removed need to be disassembled. We estinate that $4 B$ $5-\mathrm{cm}$ bolts are needed to react the $60 \mathrm{HN}\left(13.5 \times 10^{6} 1 \mathrm{bs}\right)$ tensile load ac this interface; therefore, each frame interface has 12 bolts. The crane-mounced manipulator is shown removing the upper bolts using an impact wrench in Fig. 4-1. Advanced manipulator systems (presently under development) are suitable for this operation. Note that the telescoping boom requires one articulated joint because of the Iocation of the centerline hatch.

5. Remove a portion of the inner shield annulus (Fig. 4-4) to gain access to the structural attachments between the minor octopole assembly and the frames(B). To reach this shield using the overhead manifulator, a trapezoidal access opening $(100 \times 90 \times 75 \mathrm{~cm})$ is needed through the inner and outer structural shells of the top frame ( $s$ ) between the third and fourth ribs.

6. Translate the octopole frame that is removed $0.5 \mathrm{~m}$ towards the central cell to clear the mirror/shaping coil assembly before vertically lifting the frame fron the end cell. In the present configuration, this operation is not possible because the annular shield constrains lateral movement of the frame. Therefore, either the tiirror/shaping coil asgembly mist be moved back $0.5 \mathrm{~m}$ or the annular shield must be modularized so that it becomes part of the frume assembly. Additionsl development of the end-cell configuration is needed to determine the most feasible approach.

7. Lift out the minor octopole assenbly after removing the remaining etructural attachments to the frames.

\section{DESIGN MODIFICATIONS}

We identified four design modifications that were needed in the end cell to improve diassembly and component removal operations: 


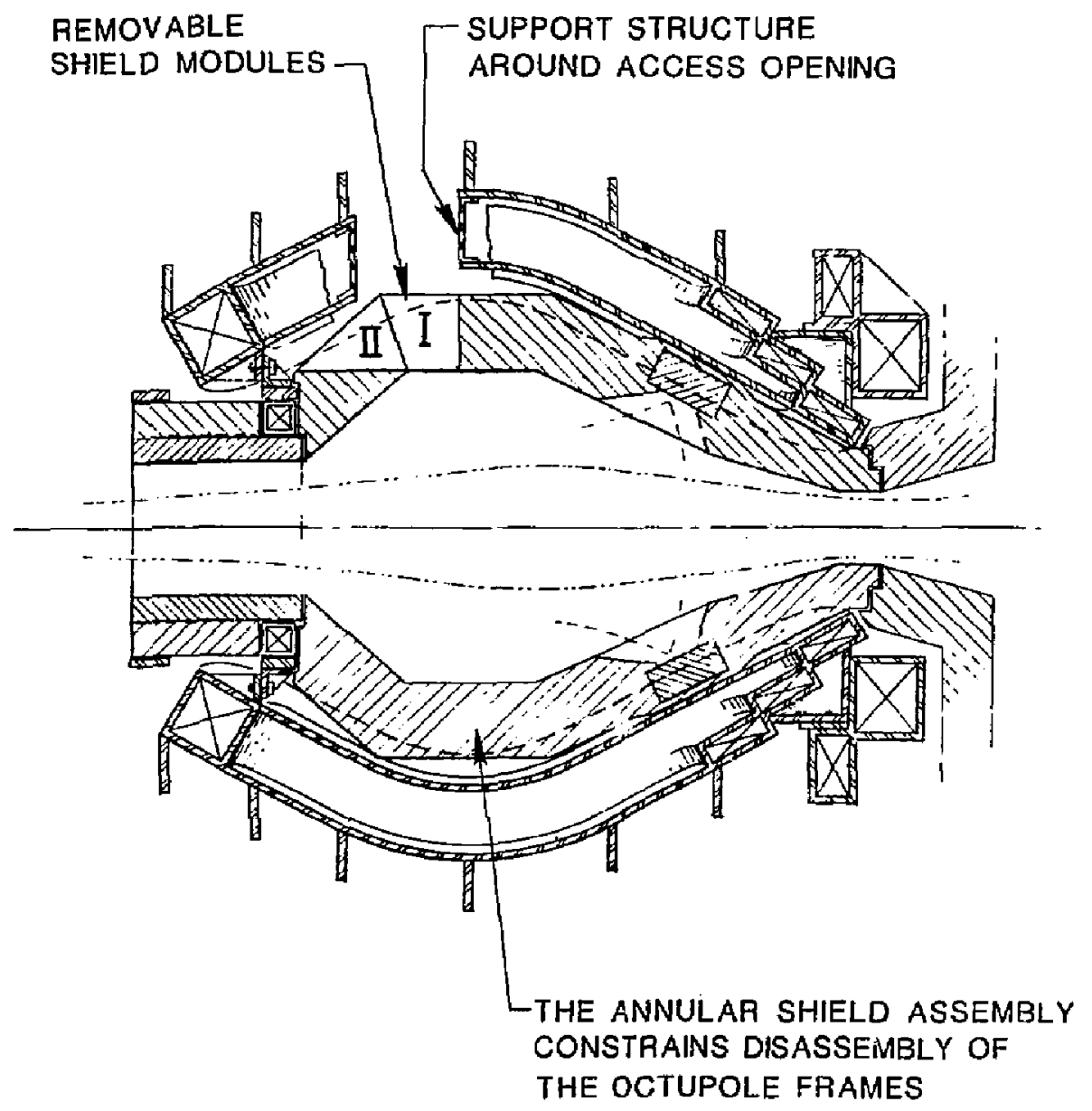

Fig. 4-4. Access requirementa for miner octopole detachment. 
1. Add a small c-nterline hatch $(1 \times 2$ m) behind the main hatch to gain access to the structure of the mirror/shaping coil assembly.

2. Aud an access opening through the inner and outer shells of the upper frame(s) and between two ribs to gair access to the annutar shield and the etructure between the minor and major octopoles.

3. Design the annular shield to have two removable pieces for access to stcuctural attachments and consider eliminating the upper gertictural actachments between the minor and major octopoles.

4. Evaluate modularizing the anmular shield va moving the mirror/shaping coil assembly to remove the octopole frames.

5. Provide an articulated joint in the telscoping boon of the cranemounted manipulatox to reach the mirror/shapizg coil struccure.

\section{REFERENCE}

1. Fueion Power Demonstrations I and IF, J. N. Doggett, Ed., Lawrence Livermore National Laboratory, Livermore, CA, UCID-i9971-1 (1985). 


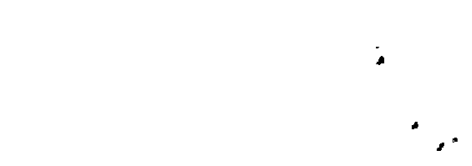

Section 5

\section{Plant Facilities}




\subsection{PLANT FACILITIES}

The Eacilities fer-FPD-III include a number of gt neric buildings that would be necessary for any large, self-contained irdustrial plant, as well as thase buildings and services unique to mirror fusion. Accordingly, we have concentrated our bulk design and arrangement effort on the unique aspects of fusion facilities. These core fusion facilities are illustrated in Figs. 5-1, -2 , and -3 . The core fusion facilities and the facilities not shown in the figures (e.g., the whehouse, maintenance shops, central control room, switchyard, ventilation stack, administrative building, ete.), weuld fill a site plan that would encompass roughly 50 acrea. Although these nonfusion facilitieg have been included in the cost estimste, they have not been specifically located or detailed at this time.

The core fusion facilities shown in Figs. 5-1, -2 , and -3 consist of a central fusion island on a common Foundation mat of approximately $4275 \mathrm{~m}^{2}$. This mat is surrounded by number of contiguous buildings on itudepen:lent foundations. The structures on the common mat include the reactor vaut, steam-generator cell, LiPb-processing cell, hot cell, decontanination cell, and component -transfer chambers. These facilities are grouped cogether because of their shared design requirements. These common criteria are seismic design, tornado missile protection, flood protection, radioactiveshielding requirements, tritium confinement, and remote-handling requirements for large components during mintenance operations. This common mat grouping may also permit some wall thickness reductions because of the interiorstructure shieling provided by exterior structures.

The mirror device for FPD-III is located in the 23-m-wide $\times 76-\mathrm{m}-10 \mathrm{ng}$ $\times 27-m-t a l l$ reactor vault. This mirror device is located slightly off center to the north side of the vault about $9 \mathrm{~m}$ above the mat. We chose this arrangement to accommodate both of the neutral beams on the scuth side of the vault, thus minimizing vault width. The vault is serviced by a 300 -tonne overhead crane, as wall as by several smaller manipulator cranes. The main crane is used for large componeat transfers in the component removal right-ofway along the north side of the vault. Both the overhead crane and its load can accesa the decontamination cell through a crane door [similar to the Joint Europeen Torus (JET) crane door concept] and a rolling shield door in the east end of the voult. 


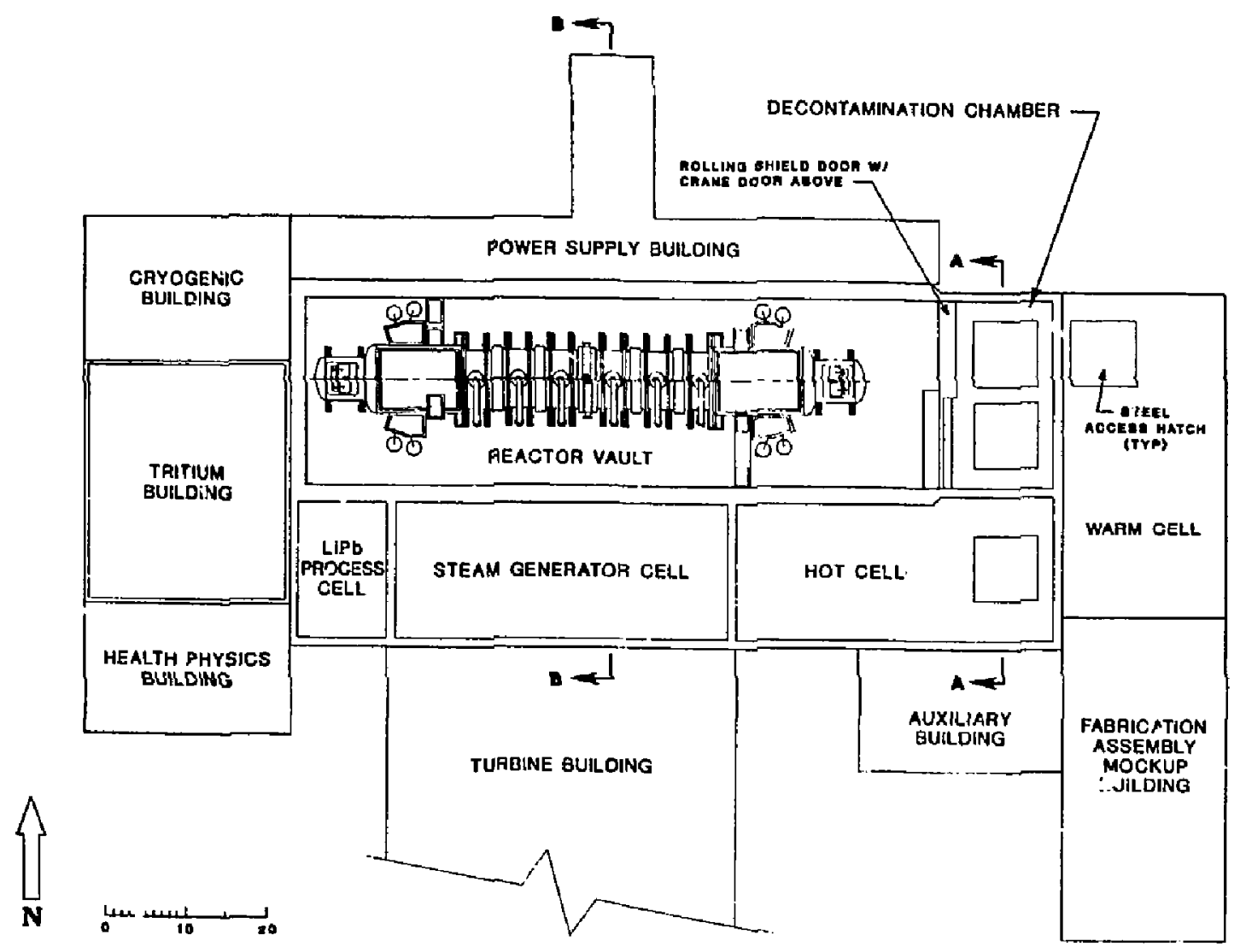

F1g. 5-1. FPD-III plan view, grade EL-0.0. 
(2)

,

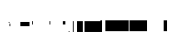

$=4 \|$

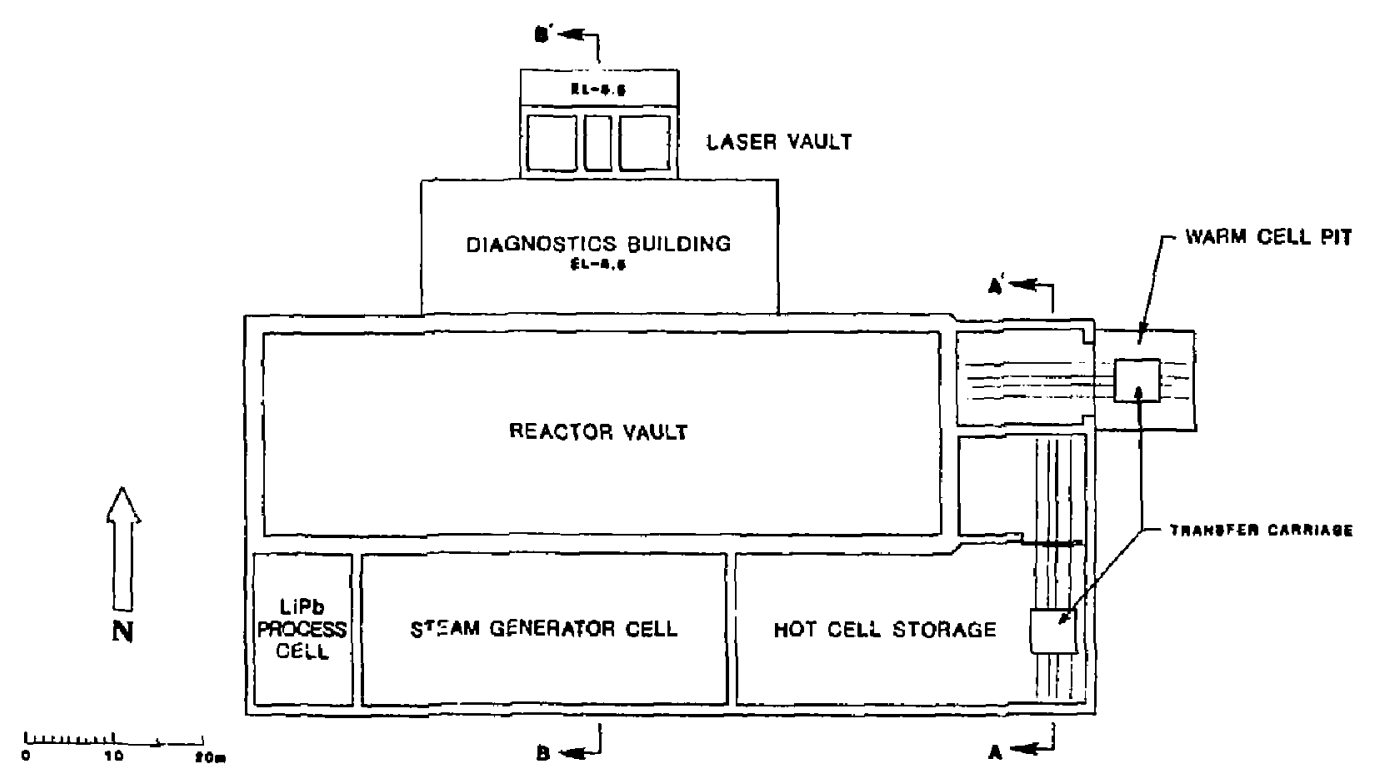

Fig. I-2, FPD-IIJ, plan view, grede EI-13.0. 


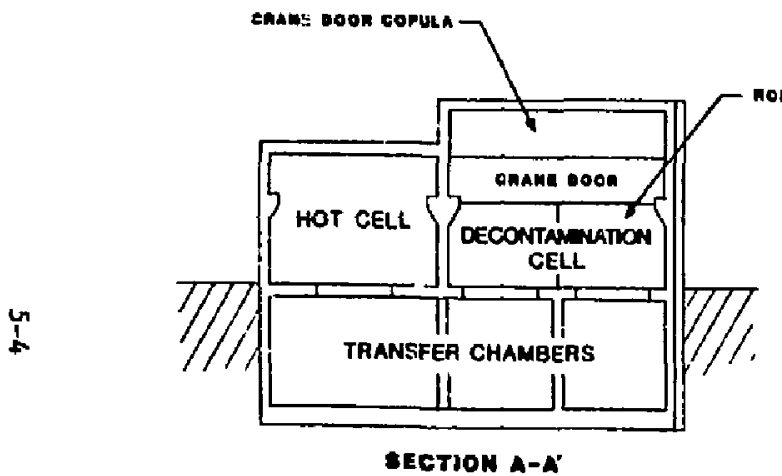

EECTION A-A

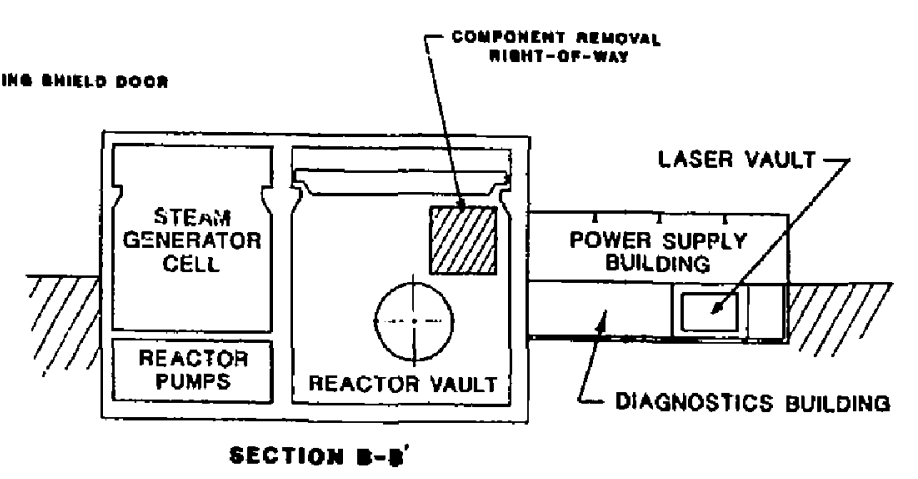

to

FIB. 5-3. FPD-III section view. 
The decontamination cell is a 14-m-wide $\times 23-m-10 n g \times 14-m-h i g h$ chamber either lined with atainlegs steel, or coated with easily washable epoxy paint. The reactor-vault overhead crane is stored in this cell during machine operation to prevent unnecessary activation of the crane. In addition, all components either entering or leaving the reactor vault must pass through the decontamination ce:1. Here, for example, activated components leaving the reactor valt are cleaned to remove loose contamination before transfer to the hot or warm ce11. This transfer is accomplished by lowering the component through the appropriate $\mathrm{s}$ reel-covered hatchway onto a rail-mounted transfer carriage in either the hot-cell or warm-cell trangfer chambers.

A component with a high enough activation level is sent to the hot cell for maintenance operations. Once lowered onto the transfer carriage, the carriage mover to a position under the hot-cell access hatch, where it can be remotely grappled and raised into the hot cell by thi not cell's 300-tonne overhesd crane. The hot cell is roughly $17 \times 39 \times 14 \mathrm{~m}$ high to accommodate several central-cell sectors. Beneath the hot cell is an area for various hot-cell services and activated-component storage.

Components having activation levels that permit hands-on maintenance are transferred to the warm cell from the decontamination cell in a manner similar to the hot-cell transfer. The warm cell is a structural-steel, metal-sided building on a separate foundation approximately $20 \mathrm{~m} \times 40 \mathrm{~m} \times 16 \mathrm{~m}$ high. It is served by its own 300-tonne overhead crane, which it shares with the adjacent fabrication, assembly, and mockup brilding of similar dimensions and design. Thus, remote maintenance operations can be prarticed and new components can enter the complex through the fabrication, assembly, and maintenance (FAM) building.

In addition to the hot cell, the south side of the common-foundation mat includes the steam-generator cell and the Lipb-process cell. This area is rough1y $17 \times 53 \times 27 \mathrm{~m}$ high and provides space for the $184 \mathrm{HW}$ of steam generarion equipant, circulating pumpo, tritium extraction equipment, and LiPb storage. This area is serviced by its own overhead crane.

The steam-gencrator cell is located near the central-ceIl region to minimize $\mathrm{LiPb}$ piping runs and on the south side of the reactor vault, which prevents interference of the large bore and heavily supported Lipb pipe with 
the component removal right-of-way. Also, because the steam-generator cel1 is located on the common mat, we do not need to account for the seismically induced, differential building motions when providing supports for the heavy LiPb pipe.

The turbine building is a structural steel, non-uclear grete, metalsided building. It is located immediately adjacent to the steam-generator celi to minimize main steam and feedwater pipe rung. It is roughiy $43 \times 45 \times 40 \mathrm{~m}$ tall, with three internal levels. It houses the 70-HW turbine-generator and all of its auxiliary systems and equipment.

The three structures along the west end of the fusion island are the cryogenic building ( $25 \times 18 \times 6.1 \mathrm{~m}$ tall), the tritium building ( $25 \times 30 \times 12 \mathrm{~m}$ tal1), and the health physics building ( $20 \times 20 \times 3 \mathrm{~m}$ tall). The cryogenics building is of standard industrial construction. It is serviced by its own 10-tonne overhead crane and houses the compressors and other components of the cryogenic liquefaction oystems. The cryogenics building is fed by a nearby tank farm where hydrogen and nitrogen gas in stored. The health physics building is of similar construction and includes change rooms, personnel radiation control and monitoring, and is the central personne: access point to the various potentialiy contaminated areas.

Although the tritium building is a reinforced concrete, nuclear-grade structure, it was not located on the common nat. Tritium, which is a beta emitter, does not reguire significant shielding walls (the reinforced sncrete esterior walls are primarily for missile protection). Tritium process piping is essentially small bore and relatively easy to route and acismically support. In addition, the tritium processing equipmeat ano atmospheric tritium recovery units houseu in the building produce relarively small structural laads that permit a thinner foundation mat than the common mat.

The power supply building is located or. the north side of the fusion island. It is a tee-shaped building to maxinize the bustar and cable access both to the reactor vaule and to the transfomers located aiong its exposed northern perimeter. This nuilding occupies dm $800 \mathrm{~m}^{2}$ twotprint, is $7.6-1 \mathrm{n}$ high, and is fabricated as a standard industrial building.

Beneath the power-supply building is the iagncstics building and the laser-fueling vault. These buildings are of standard industrial construction. 
They are locaced slightly below grade to permit "line-of-sight" communication with the device. For example, a focusing tube runs horizontally from the laser vault, through the diagnostics building, and directly to the centerline of the central-cell region of the device. This focused laser beam is used in conjunction with pellet fuelers (located adjacent to the reactor vault in the diagnostics building) to add fiel to the reactor.

Finally, located adjacent to the hot cell and FAM building is the nonnuclear, standard-industrial-construction, alxiliary building $(15 \times 25 \times 6.1 \mathrm{~m}$ high). It houses the non-nuclear-grade component-cooling system; the auxiliary boilar; the heating, ventilating, and air conditioning (HVAC) service for nearby facilities; and various miscellaneous systers.

In sumary, the arrangement of the facilities described here appears feasible from a preconceptual perspective. However, considecable detis remains to be developed, which is well beyond the scope of this present effort. Syctem procesa flow diagrams, piping drawings, equipment sizes and outline dimensions, heat transport and power generation cycle, as well as maintenance and operating scenarios must be developed before reasonable conceriual facility arrangements can be designed. 
Section 6

Cost Projection 
The total construction cost that we project for the FPD-III facility is sumarized in Table 6-1. This cost projection is in millions of mid-1984 dollars and is based on the following assumptions:

- The facility will be constructed on an undeveloped national Laboratory site.

- The device wil be conotructed by a prime contractor who is responsible to the national labor tory for engineering, procurement, and construction.

Our approach to assembling the FPD-III cost projection consists of parallel project design and cost database activities. Early in the project we developed a detailed code of accounts (work breakdown structure), compatible with the FPD-III project, which was below the mandatory livel of the standard Fusion Engineering Design Center (FEDC) Code of Accounts to add conformity to the development of the cost projection. We assigned cognizant engineers the responsibility of providing the technical input to project costs for the various components and/or subsystems in the code of accounts. At the point when quantities of material and equipment could be estimated, the cognizant engineers submitted standardized component-design data sheets along with supprting material for their assigned elements in the code of accounts. These design data sheets included the design basis, the design description, and a listing of the pertinent design parameters. This assemblage of component/tubsyoten design data sheets in conjunction with the cost database Eile form the basis for FPD-III cost projection.

The cost database file, which is the product of the ongoing Fier cost database activity, is a catalog of cost coefficients, algorithms, and component costs yrranged in a standard format on separate cost data sheets corjesponding ca spccific components and subsyatems. These cost daca sheets contain engineering, equipment, and labor cost data for different configurations and types of specifiz component/subsystems. We developed the cost database file from actual coat experience and refined it to be cmpatible with the FEDC 
Table 6-1. The FPD-III projected-cost summary.

\section{Account}

number
Account title
$\operatorname{Cost}(84 \mathrm{M} \$)^{\mathrm{a}}$
221

222

223

224

225

226

227

228

229

23

24

25

26

91

92

93

94
Land and land riglits

Structures and site facilities

Reactor plant equipment

Reactor systems

Magnet systems

Power injection systems

Vacuum syste is

$$
\text { Power conditicisung systems }
$$

Heat transport systems

Fuel handling systems

Instrumentation and control

Maintenance equipment

Turbine plant equipmert

Electric plant equipment

Miscellaneous plant equipmant

Heat rejection system

Total direct cost

Construction services and equipment

Home office engineering and services

Field office engineering and services

Owner's cost

\section{0}

124.0

859.46

141.4

178.8

123.34

9.3

71.30

84.0

84.5

72.6

94.1
46.7

15.4

25.5

9.4

1080.47

54.02

108.05

10. :0:

54.02

Total indirect cost

$324 \cdot 14$

Contingency

421.38

1826.00

\section{Total constructed cost}

a Millions of doljars. 
cost-projection methodology. Table 6-2 shows a detailed cost breakdown of the FPD-III cost elementa. He developed and defined these projected costs according to the standard FEDC Code of Accounts and cost element definitions. The total constructed cost of the facility is composed of direct costs, indirect costs, and contingency costs. Direct costg are the equipment, engineering, and labor costs that are specifjcally identified with a permanent plant component or facility. Equipment cosis include the purchase price of commercially available materials and equipment delivered to the site, and che "build-to-print" costs ineurred by the project and its subconcractirs. The "build-to-print" cost is defined so that it represents the purchase price of the component if it were commercially avilable and includes materials, fabrication, labor, tooling, packaging and shipping, acceptance testing, as vel1 as recurring manufacturing-support engineering.

We defined the engineering element of direct cost to include the firstof-a-kind, nonrecurring engineering costs. Engineering consists of design management, design engineering, analysis, specification and drawing development, process verification testing, and tool design. Labor costs refer to the cost of craft labot used for assembly and on-site acceptance testing of the permanent plant equipment and subsystems. We calculated direct costs using design parameters and descriptions from the design data gheets submitted by the cognizant engineers and cost data obtained from the cost database file on a similar component/subsystem. Three techniques were used tc estimate the equipatent cost for a specific component and/or subsysten. These were unit costing, cost algorithms, and "component takeoff" costing . When a solid historical database was available for costing a specific component/subsystem, we used the unit costing method; whereby, the cost is based on cost per unit (weight, area, volume, etc.) of similer equipment. When a sad database did not exist, we employed the cost algorithm method of costing. Cost algorithms are empirical costing equations, developed from experience on similar hardware, where the cost is staled as a function of cumponent design parameters. When the rubsy日tem is composed of standard items, whare wsts are accurately known, a "component takeoff" method is used whereby the subsystem cost is based on the unit cost and quantity of the components that comprise the systen. We calculated engineering cost and labor cost for the component/subsystem using a percentage of equipment cost extracted fron the coat dacabase file. 
Table 6-2. The FPD-III facility cost projection (numbers in brackets indicate subtotals).

\begin{tabular}{|c|c|c|}
\hline $\begin{array}{l}\text { Account } \\
\text { number }\end{array}$ & Account title & $\begin{array}{c}\text { Projected cost } \\
(84 \mathrm{M \$})^{\mathrm{a}}\end{array}$ \\
\hline 20 & Land and land rights & 0 \\
\hline $2 I$ & Structures and site facilities & {$[124.0]$} \\
\hline 211 & Site improvements/facilities & 17.5 \\
\hline 212 & Reactor building & 28.3 \\
\hline 213 & furbine building & 15.4 \\
\hline 214 & Reactor maintenance buildings & {$[20 . j]$} \\
\hline 214.1 & Hot cell & 17.3 \\
\hline 214.2 & Warm ce11 & 2.4 \\
\hline 214.3 & Mockup building & 0.9 \\
\hline 215 & Tritium building & 10.1 \\
\hline 216 & Electrical equipment buildings & [17.1] \\
\hline 216.1 & Field-coil power-supply building & 1.5 \\
\hline 216.2 & RF power-supply building & 0 \\
\hline 216.3 & Steam-generator building & 15.6 \\
\hline 217 & 0ther buildings and structures & {$[15.1]$} \\
\hline 217.1 & Adminiscration building & 1.5 \\
\hline 217.2 & Radwaste building & 0.3 \\
\hline 217.3 & FAM building & 4.9 \\
\hline 217.4 & Diagnostic building & 1.1 \\
\hline 213.5 & Gryogenics building & 0.5 \\
\hline 217.6 & Plant-auxiliary building & 0.4 \\
\hline 217.7 & Switchyard & 0.2 \\
\hline 217.8 & Vent stack & 0.1 \\
\hline 217.9 & Control-room building & 3.3 \\
\hline 217.10 & Securıty building & 0.4 \\
\hline 217.11 & Warehouse & 1.8 \\
\hline 217.12 & $\begin{array}{l}\text { Miscellaneous buildings and } \\
\text { Btructures }\end{array}$ & 0.6 \\
\hline
\end{tabular}


Table 6-2. (Continued.)

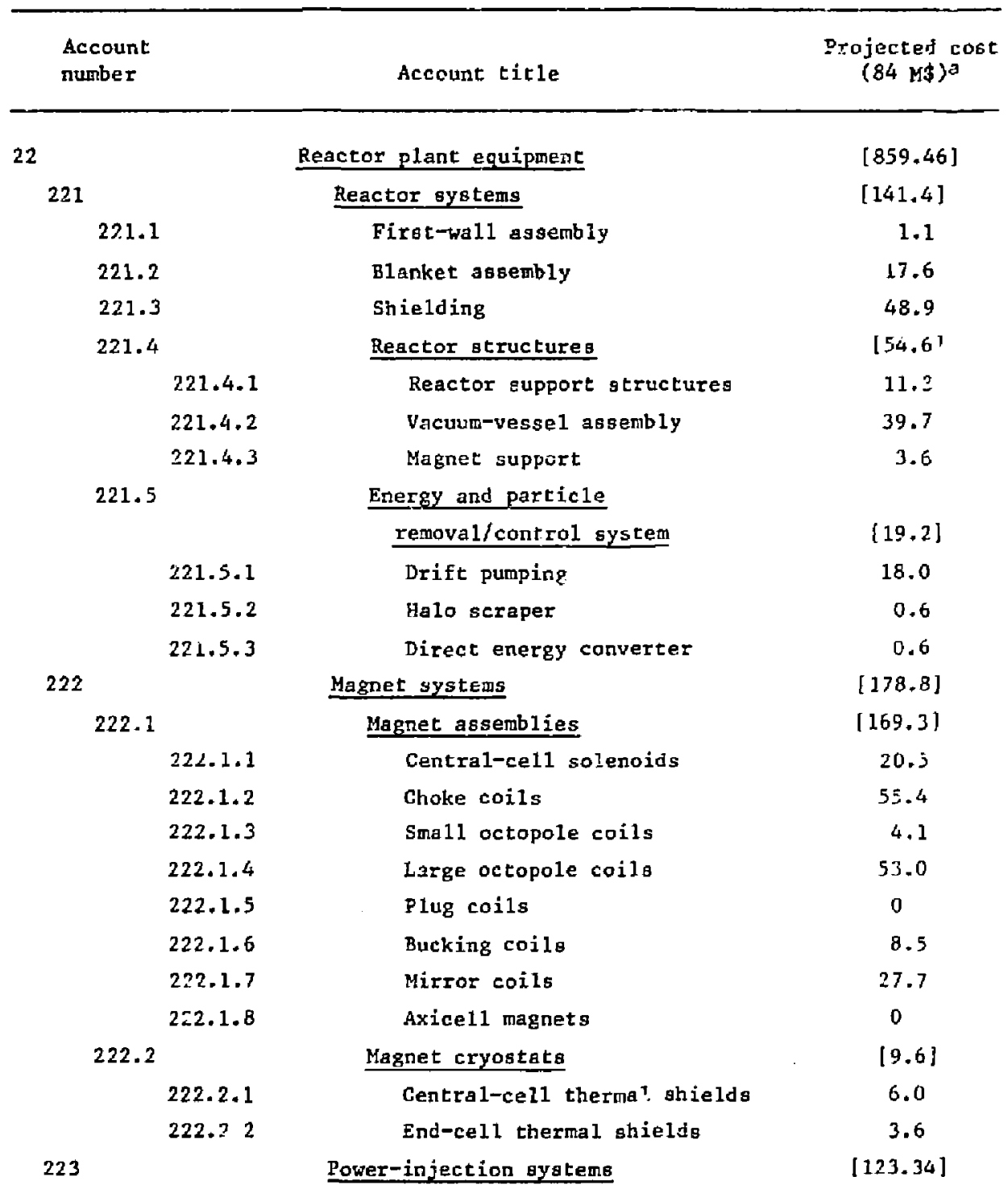


Table 6-2. (Continued.)

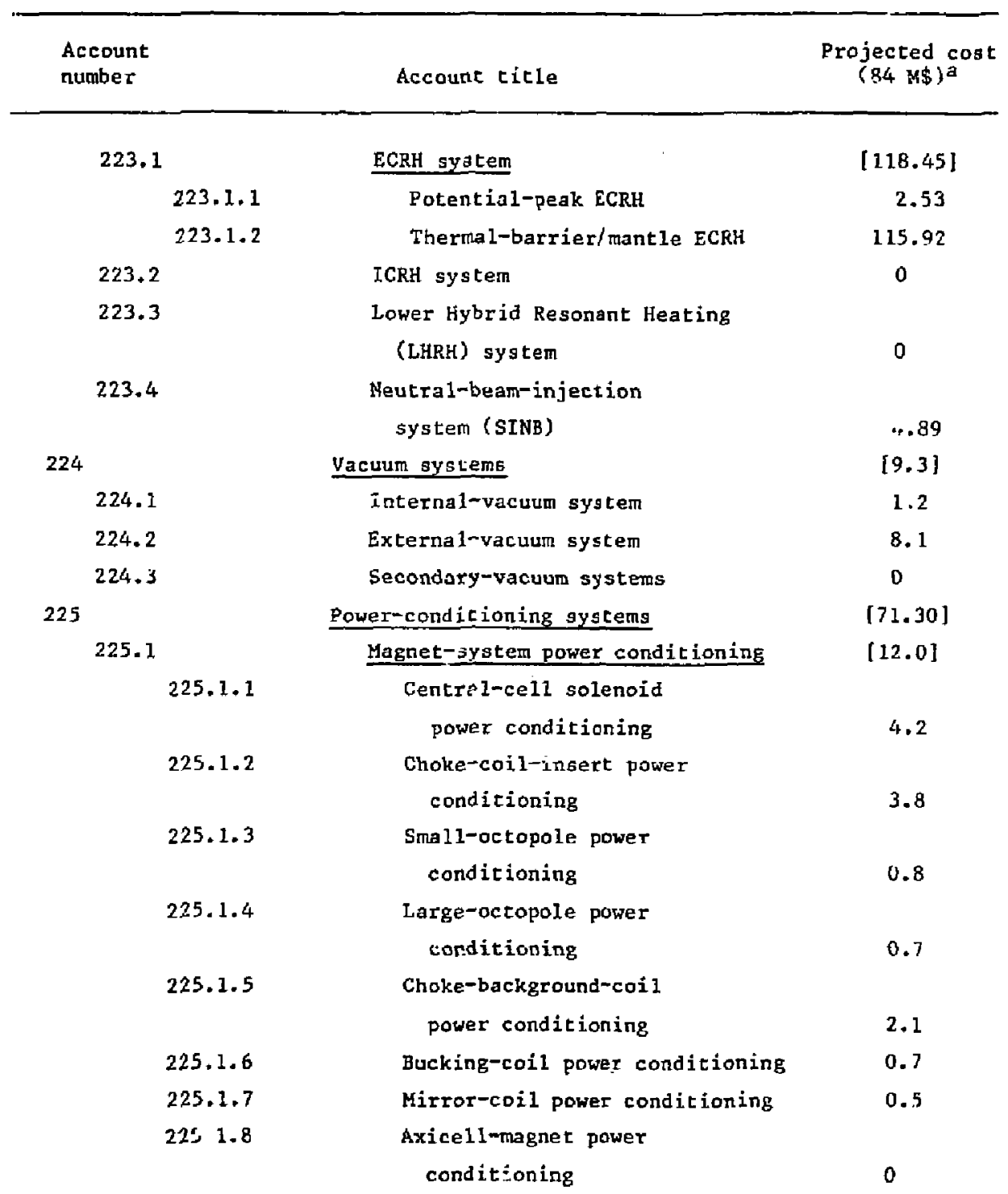


Table 6-2, (Continued.)

Account

number
Account title
Projected cost

$(84 \mathrm{H} \$)^{a}$
225.2

$225 \cdot 2 \cdot 1$

225.2 .2

225.2 .3

225.2 .4

225.3

225.3 .1

225.3 .2

225.4

226

226.1

226.2

226.3

226.4

226.5

227

227.1

227.2

227.3

227.4

227.5

227.6

228

228.1

228.2
Power-injection-system

power conditioning

[33.23]

ECRH power canditioning

30.75

ICRH power conditioning

0

0

2.1

NBI power conditioning

Energy and particle removal/ contiol power conditioning

[25.2]

Direct-conversion inverter

2.7

Drift-pump power conditioning

2.2 .5

Energy storage

0

Heat-transport systems

Blanket heat-transport system

$[84,0]$

42,2

Shield heat-transport system

3.7

Cryogenic-cooling aystem

33.5

Water-cooling system

3.9

Gas-cooling system

0.7

Fue1-handling syotems

[84.5]

Fue1-injection system

12.7

Fue1-processing and purification aystem

$16: 7$

Storage and receiving systems

5.0

Atmospheric-recovery systems

8.5

Wacer-recovery systems

0

Blanket-recovexy systems

41.5

Instrumentation and control system

$[72.6\}$

Data-acquisition system

14.5

Man-machine interface

2.6 
Table 6-2, (Continued.)

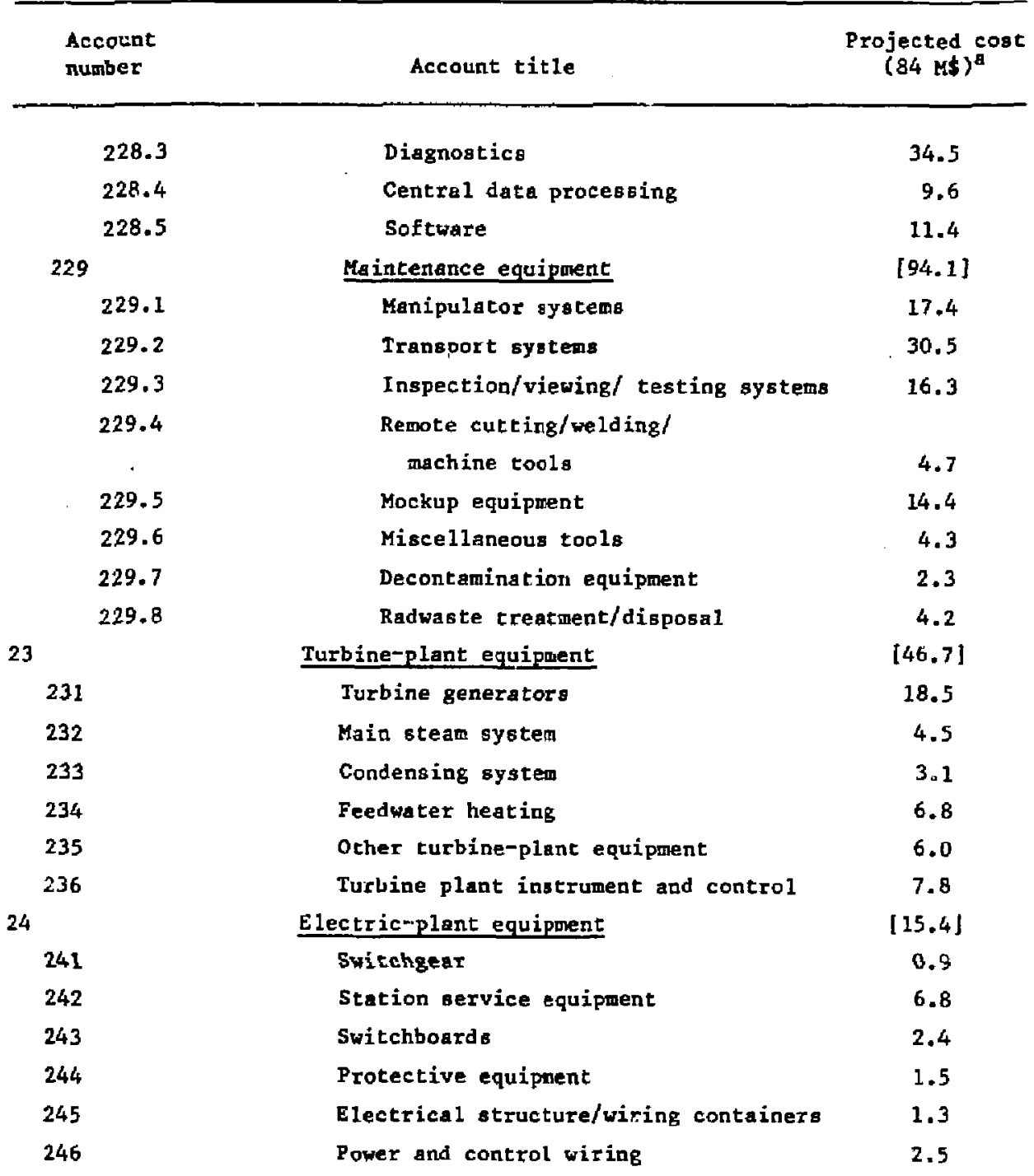


Table 6-2. (Continued.)

\begin{tabular}{|c|c|c|}
\hline $\begin{array}{l}\text { Account } \\
\text { number }\end{array}$ & Account title & $\begin{array}{l}\text { Projected cost } \\
(84 \mathrm{M} \$)^{\mathrm{a}}\end{array}$ \\
\hline 25 & Miscellaneous plant equipment & {$[25.5]$} \\
\hline 251 & Transportation and lifting equipment & 2.6 \\
\hline 252 & Air and water service systems & 2.7 \\
\hline 253 & Communications equipment & 1.7 \\
\hline 254 & Furnishings and fixtures & 0.6 \\
\hline 255 & Bulk materials & 17.9 \\
\hline 26 & Heat-rejection system & {$[9.4]$} \\
\hline 261 & Structures & 3.4 \\
\hline \multirow[t]{2}{*}{262} & Mechanical equipment & 6.0 \\
\hline & Total direct cost & {$[1080.47]$} \\
\hline 91 & Construction services and equipment & 54.02 \\
\hline 92 & Home office engineering and services & 108.05 \\
\hline 921 & Project management & 43.22 \\
\hline 922 & Project systems engineering & 43.22 \\
\hline 923 & Project qualicy assurance & 21.61 \\
\hline 93 & Fiel:i office engineering and Bervices & {$[10 B, 0]$} \\
\hline 931 & Congtruction management & 64.8 \\
\hline 932 & Inspection & 21.6 \\
\hline 933 & Preoperational testing & 21.6 \\
\hline 94 & Owner $8 \operatorname{cost}(\mathrm{LLNL})$ & {$[54.0]$} \\
\hline 941 & Project adminietration & 32.4 \\
\hline \multirow[t]{5}{*}{942} & Inventories and spares & 21.6 \\
\hline & Total indirect cost & {$[324.1]$} \\
\hline & Direct + indirect $\cos t$ & {$[1414.6]$} \\
\hline & Contingency & 421.4 \\
\hline & FPD-III total conatructed cost & {$[1826.0]$} \\
\hline
\end{tabular}

${ }^{a}$ Millions of dollars. 
Indirect costs are those costs that are not identified with specific permanent plant facilities, equipment, or systems; but are incurred by the project as a whole. Indirect costs include those costs that cannot be idertified with a direct account and those that do not warrant the detailed accounting required for distribution to direct accounts. This type of cost is judged to be best controlled as an indirect accsunt.

Four indirect cost elements were calculateö, by subelement, using percentages of the total direct cost. Construction services and equipment include temporary construction facilities, constuction equipment, taxes, and insurance. He chose an allowance of $5 \%$ of the total direct cost for this element of indirect cost. Home office engineering and bervices consists of the overall sygtems engineer ing, management, and services provided by the prime contractor mainly during the design phase. Major elements are project management (project administration, cost/schedule, technical coordination, data management, etc.); project systems engipeering (systems integration, configuration control, safety, systems analysis, etc.); and project qualicy assurance (procedures development, review, audit, surveillance, reporting). We chose allowances of $4 \%, 4 \%$, and $2 \%$ of the total direct cost for project management, project systems engineering, and project quality assurance, respectively + Field office engineering and services consists of the primecontractor-associated activities at the job oite during congtruction, and also includes construction management (site supervision, construction scheduling, procurement and contract administration, construction engineering, etc.), inspection (site), and pre-operational testing. He chose allowances of $6 \%$, $2 \%$, and $2 \%$ of the total direct cost for construction managenent, inspection, and pre-operational testing, respectively. Owner's cost consists of the overall project engineering and services cost incurred by the laboratory (LLNL) in addition to initial inventories. Major elements of owner"s cost are project adminiatration, inventoriss, and spares. We chose an allowance of $3 \%$ of the cotal direct cost for project gdministration and an allowance of $2 \%$ of the total direct cost for inventories and spares. These elements are sumed to form the total indirect coat of the facility.

Contingency is cost allowance included in the cost projection to reflect the fact that uncertainties exist in the project definition, unit 
pricing, and execution. The magnitude of the contingency allowance depends on the project phase. We chose an allowance of $30 \pi$ of the subtotal of the total direct cost and total indirect cast to reflect the uncertainties associated with a preconceptual-level cost projection. We did not address the cost of operations and basic research and developwent in this cost projection. 
Section 7

Issues 


\subsection{ISSUES}

ISSUE I

Areas requiring more detail design study to establish feasibility include the following:

Sull octopole region. The region around the small octopole is very crowded. Work to date showg that major components of structure and shielding can fit into the space, and that neutral-beam pathe are posaible through the region. However, details of these components such as piping for the actively cooled shield, coil-electrical leads, and the coil-refrigerant lines will compete with the drift-pumping coil and its associated leads for this space. Hechods for assembly/disassembly of these components must be considered as part of the coil installation/removal scheme. Work to date has not addressed these problems.

Axial tie of the choke coil to the last central cell. The mutual force of attraction between the choke coil and the solenoid in the outermost central cell is $1.2 \times 10^{8} \mathrm{~N}(\sim 27$ million pounds). Methods to support this load internal to the coils by transferring it from the windings to the coil structure as well es a conceptual design of a method to tie the two coils together should be addressed.

Position of the bucking and mirror coils relative to the large octopole. The general assembly scheme of the end cell, and thus the maintenance concept, is greatly influenced by the relative position of these coils. The present configuration greatly ithibits the possible segmentation of the octopole into discrete modules that cauld be handled individually. If posaible, this segmentation would result in crane access to components installed internal to the octopole, principally the small octopole and shielding, and, therefore, reduce the size of the crane required for the facility because more components could be handled individually rather than as a large assembly. 
Drift punp ineues. Although there are drift-pumping experimental efforts on both Constance at the Magsachusetta Institute of Technology and the Tandem Mirror Experiment-Upgrade (TMX-U) at LLNL, the magnetic configuration and, hence, the type of launcher structure are entirely different from the requirements for an actopale configuration. An improved model to caiculate the required field perturbation, $B$, and a knowledge of the plasma-edge geometry and plasma parameters are necessary before launcher concepts can be developed.

Configuration/maintenance. (End-cell ennular shield): The end-cell annular shield substantially complicates the assembiy/disassembly of interfaces between the major and minor octopoles. Based on the end cell details developed for FPD-III, there appears to be issufficient access to the minor-octopole support structure. To help solve this issue, the annular ahield requires segmentation into godules. These modules must be removable as small pieces near the upper octopole region, and must also have integral attachment as large pieces to the upper octopole frame(a). Detailed configuration development of the end cells is needed to define the modularity of the shield and any aize changes to components that are necessary to provide sufficient clearances.

Blanket deaign. In this study, the thermal hydraulic, MHD, and lifetime and mechanical design problems of a liquid lithium-lead blanket heve not been addressed. The space allocated to the blanket is based on preliminary neutronics analyes. Detail deaign is required with both analysis and component performance teating to establish feasibility. No completely adequate tritium-breeding blanket for a fusion reactor hes yet been degigned.

ISSUE II

Areas exceeding present technology limits include the following:

Magnetic field strength on superconducting windings. Two coils in the end-coil set, referred to as the bucking and mirrar coils, are located in regions of high magnetic fields and simultaneously require current densities of approximately $5000 \mathrm{~A} / \mathrm{cm}^{3}$. This combination exceeds todays technology. 
Pellet fueling ayeten. Considerable uncertainty exists in the physics model used to determine the pellet-laser beam-fueling requirements. Singleohot experimenta are needed to determine penetration of the fueling plume into a fusion grade plasm. For the fueling requirements given in this report, there are no laser systems available today that meet both the repetition-rate and beam-energy requirements. 